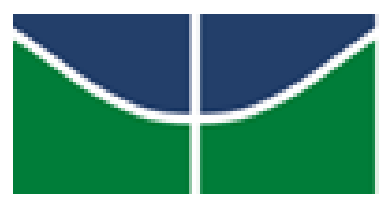

UNIVERSIDADE DE BRASÍLIA

INSTITUTO DE PSICOLOGIA

Programa de Pós-Graduação em Processos de Desenvolvimento Humano e Saúde

DESENVOLVIMENTO DO SISTEMA DE SELF DE JOVENS CATÓLICOS

VOCACIONADOS À VIDA RELIGIOSA CONSAGRADA

CLÁUdIO MÁRCIO DE ARAÚJO

Brasília, dezembro de 2016 


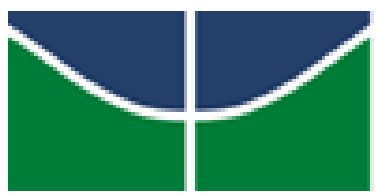

Universidade de Brasília

Instituto de Psicologia

Departamento de Psicologia Escolar e do Desenvolvimento

Programa de Pós-Graduação em Processos de Desenvolvimento Humano e Saúde

Área de concentração: Desenvolvimento Humano e Educação

Linha de pesquisa: Processos de Desenvolvimento e Cultura

\section{DESENVOLVIMENTO DO SISTEMA DE SELF DE JOVENS CATÓLICOS VOCACIONADOS À VIDA RELIGIOSA CONSAGRADA}

\section{Cláudio Márcio de Araújo}

Tese apresentada ao Instituto de Psicologia da Universidade de Brasília, como requisito parcial à obtenção do título de Doutor em Processos de Desenvolvimento Humano e Saúde. Área de concentração Desenvolvimento Humano e Educação.

ORIENTADORA: Prof. ${ }^{a}$. Dra . Maria Cláudia Santos Lopes de Oliveira 
Ficha catalográfica elaborada automaticamente, com os dados fornecidos pelo(a) autor(a)

\begin{tabular}{|l|l|}
\hline AAR663 \\
$\mathrm{d}$ & $\begin{array}{l}\text { Araújo, Cláudio Márcio } \\
\text { Desenvolvimento do sistema de self de jovens } \\
\text { católicos vocacionados à vida religiosa consagrada / } \\
\text { Cláudio Márcio Araújo; orientador Maria Cláudia } \\
\text { Santos Lopes de Oliveira. -- Brasília, 2016. } \\
173 \mathrm{p.}\end{array}$ \\
& $\begin{array}{l}\text { Tese (Doutorado - Doutorado em Processos de } \\
\text { Desenvolvimento Humano e Saúde) -- Universidade de } \\
\text { Brasília, 2016. }\end{array}$ \\
1. transições juvenis. 2. vida religiosa \\
consagrada. 3. psicologia cultural. 4. horizonte de \\
projeção de self. I. Lopes de Oliveira, Maria Cláudia \\
Santos, orient. II. Título.
\end{tabular}




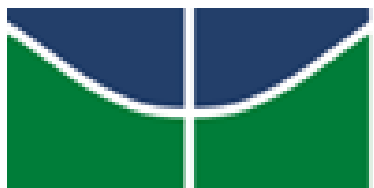

Universidade de Brasília

Instituto de Psicologia

Departamento de Psicologia Escolar e do Desenvolvimento

Programa de Pós-Graduação em Processos de Desenvolvimento Humano e Saúde

Área de concentração: Desenvolvimento Humano e Educação

Linha de pesquisa: Processos de Desenvolvimento e Cultura

A Tese de Doutorado "DESENVOLVIMENTO DO SISTEMA DE SELF DE JOVENS

CATÓLICOS VOCACIONADOS À VIDA RELIGIOSA CONSAGRADA", de autoria de

Cláudio Márcio de Araújo, foi aprovada pela seguinte banca examinadora:

Prof. ${ }^{a}$. Dr ${ }^{\mathrm{a}}$. Maria Cláudia Santos Lopes de Oliveira - Presidente

Universidade de Brasília (UNB)

Prof. Dr. Maristela Rossato - Membro Titular

Universidade de Brasília (UNB)

Prof. Dr. Mário Miguel Machado Osório Gonçalves - Membro Titular

Universidade do Minho (UMinho)

Prof. ${ }^{a}$. Dr ${ }^{\mathrm{a}}$. Elsa de Mattos - Membro Titular

Universidade Federal da Bahia (UFBA)

Prof. ${ }^{a}$. Dr ${ }^{\mathrm{a}}$. Tatiana Yokoy de Souza - Membro Titular

Universidade de Brasília (UNB)

Prof. . . Dr ${ }^{\mathrm{a}}$. Ana Cláudia Rodrigues Fernandes - Membro Suplente

Secretaria de Educação do Distrito Federal - SEEDF 
Dedico este trabalho à minha mãe Aparecida Maria de Araújo 


\section{AGRADECIMENTOS}

Foram muitas as pessoas que participaram, direta ou indiretamente, da minha trajetória acadêmica no doutorado. A todas elas o meu muito obrigado!

À minha mãe, Aparecida Maria de Araújo, que sempre foi uma motivação na minha caminhada.

Aos meus familiares e amigos que compreenderam as ausências em momentos importantes de suas vidas.

Aos meus alunos de ontem e de hoje, crianças, jovens e adultos, que me desafiaram na compreensão dos processos de aprendizagem e de desenvolvimento humano.

À minha amiga Irmã Adilaza Silveira de Paula que, por várias vezes, foi compreensiva com meu desejo de aprofundar nos estudos. Ela que é um exemplo de respeito aos limites e possibilidades do outro.

À professora e orientadora Maria Cláudia que em dez anos de convivência tem sido uma presença decisiva na minha formação como pesquisador dos processos de desenvolvimento humano.

A todas as professoras, alunos, alunas, funcionários e funcionárias do Instituto de Psicologia da Universidade de Brasília, especialmente àquelas e àqueles que, ora mais, ora menos, estiveram presentes nessa trajetória acadêmica.

Aos componentes de hoje e de ontem do nosso grupo de estudos e pesquisa GAIA, espaço importante na minha formação como pesquisador, como pessoa e como colega.

Aos frades franciscanos da Província do Santíssimo Nosso de Jesus do Brasil, instituição na qual fui candidato à vida religiosa consagrada no período de 1997 a 2000.

Ao professor Miguel Gonçalves e aos membros do seu grupo de pesquisa que me acolheram na Universidade do Minho, Braga, Portugal, onde tive o prazer de estar por onze meses, em estágio de doutorado sanduíche.

À CAPES que possibilitou suporte financeiro para a realização deste trabalho no período de 2014 a 2016.

Aos institutos de vida consagrada que, na pessoa de seus representantes, possibilitaram meu contato com os jovens participantes dessa pesquisa. 
À minha banca de qualificação: Ângela, Elsa e Tatiana; e de defesa de tese: Elsa, Miguel Gonçalves, Maristela, Tatiana e Ana Cláudia. Suas contribuições formais e informais foram fundamentais na realização desse estudo.

Um agradecimento especial aos jovens que participaram dessa pesquisa. Eles aceitaram partilhar comigo uma parte muito bonita de suas vidas: a trajetória vocacional para a vida religiosa consagrada. Por várias vezes me impressionaram com posicionamentos de coragem, determinação, dedicação e alegria. Aprendi muito com cada um deles. 
Esta pesquisa contou com os seguintes apoios institucionais:

Comitê de Ética em Pesquisa do Instituto de Ciências Humanas (UnB). Aprovação do projeto de pesquisa, processo $\mathrm{n}^{\circ} 879.700 / 2014$

Coordenação de Aperfeiçoamento de Pessoal de Nível Superior (CAPES). Concessão de bola de estudos para a realização do doutorado mediante o Programa de Demanda Social.

Coordenação de Aperfeiçoamento de Pessoal de Nível Superior (CAPES). Concessão de bola de estudos para a realização do Estágio de Doutorado Sanduíche em Portugal, mediante o Programa Institucional de Bolsas de Doutorado Sanduíche no Exterior - PDSE ( $n^{\circ}$ do processo BEX 6235/14-0).

Universidade do Minho, em Braga, Portugal - local de realização do Estágio de Doutorado Sanduíche no Exterior, sob a supervisão do Professor Dr. Mário Miguel Machado Osório Gonçalves. 
Feliz de quem entende que é preciso mudar muito pra ser sempre o mesmo.

Dom Helder Câmara 


\section{RESUMO}

Araújo, C. M. (2016). Desenvolvimento do sistema de self de jovens católicos vocacionados à vida religiosa consagrada (Tese de Doutorado). Instituto de Psicologia, Universidade de Brasília, Brasília, DF.

Esta pesquisa investiga, numa perspectiva semiótico-cultural, transições de desenvolvimento e sistema de self à luz da experiência de jovens em formação para a vida religiosa consagrada. Fundamentado na psicologia cultural, o estudo interpretou fenômenos psicológicos como processos dinâmicos constituídos na fronteira entre o pessoal e o cultural. A abordagem metodológica foi qualitativa de cunho etnográfico. Participaram da pesquisa quatro jovens (dois do sexo feminino e dois do sexo masculino), entre 19 e 25 anos, em experiência formativa para a vida religiosa consagrada. Os instrumentos utilizados foram um guia de evocação de narrativas escritas, um diário de campo e duas entrevistas narrativas individuais e presenciais: a primeira do tipo história de vida e a segunda do tipo episódica. Ao longo de 27 meses, o pesquisador esteve em contato com os participantes e o intervalo entre as duas entrevistas foi de 15 meses, em média, o que caracterizou esta investigação como um estudo longitudinal. A análise dos casos enfatizou a construção de sentidos na orientação e regulação de transições de desenvolvimento no tempo irreversível. Processos de internalização e externalização, momentos de ruptura, sentimentos de ambivalência e signos hipergeneralizados se mostraram expressivos na compreensão dessas transições em diálogo com Horizontes de Projeção de Self (HPS). O conceito de HPS, elaborado com base nos resultados da pesquisa, contribuiu na compreensão do modo como a orientação para o futuro passa a integrar o sistema de self, destacando a dimensão temporal do desenvolvimento humano, em diálogo com recursos simbólicos e esferas de experiência. Os resultados indicam ainda que os contextos de formação para a vida religiosa canalizaram ressignificações das dimensões do sistema de self, particularmente durante momentos de mudança e ruptura, como o ingresso dos jovens no contexto institucional religioso e a vivência das etapas de formação ali propostas. Reposicionamentos identitários e socioculturais, decorrentes das transições juvenis, são vividos e interpretados neste encontro entre sujeito e realidades socioinstitucionais. Os jovens religiosos assumem posicionamentos identitários que coordenam experiências de transição, delineando trajetórias singulares. Protagonizam novas formas de ser jovem e ser religioso, reinventamse numa relação dialógica e temporal entre expectativas pessoais e socioculturais.

Palavras-chave: transições juvenis, vida religiosa consagrada, psicologia cultural, Horizonte de Projeção do Self. 


\begin{abstract}
Araújo, C. M. (2016). Self system development of young Catholic persons devoted to consecrated religious life. Tese de Doutorado, Instituto de Psicologia, Universidade de Brasília, Brasília.

This research aimed at investigating, in a semiotic-cultural perspective, developmental transitions and self-system in light of the experience of young people in formation for consecrated religious life. The study, based on Cultural Psychology, interpreted psychological phenomena as dynamic processes formed at the border between the personal and the cultural. The methodological approach was qualitative and of an ethnographic nature. Four young people (two females and two males), in a formative experience for consecrated religious life, aged between 19 and 25 years, participated in the study. The instruments used were used as guides to evoke written narratives, field diaries and two face-to-face narrative individual interviews: being the first one a life-history interview and the second an episodic interview. Over the course of 27 months the researcher was in contact with the participants and the gap between the two interviews was, on average, 15 months, which defines this investigation as a longitudinal study. The study cases emphasized the production of meanings in the orientation and regulation of developmental transitions in the irreversible time. The processes of internalization and externalization, moments of rupture, feelings of ambivalence and hypergeneralized signs, have been expressive in the understanding of these transitions in dialogue with the concept of the Self Horizon Projection (SHP). Such a concept was, based on the results of this research and contributed to the understanding of the way in which the orientation towards the future starts to integrate the self system, highlighting the temporal dimension of human development, in dialogue with symbolic resources and spheres of experience. The results also indicate that context formation for religious life channelled resignificances of the dimensions of the self system, particularly during times of change and rupture, such as the entrance of young people into the religious institutional context and the experience of the different stages they took part while undergoing institutional training. Identity and sociocultural repositioning, resulting from youth transitions, are lived and interpreted in the encounter between subject and socio-institutional realities. The young religious people assume different identity positions that coordinate experiences of transition, outlining unique trajectories. There are different and new forms of being young and religious, reinventing themselves in a dialogical and temporal relationship between personal and sociocultural expectations.
\end{abstract}

Keywords: juvenile transitions, religious life consecrated, Cultural Psychology, Projection Horizon of the Self. 


\section{SUMÁRIO}

AGRADECIMENTOS.............................................................................................................................ii

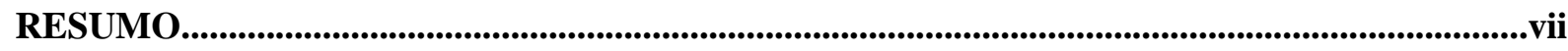

ABSTRACT .....................................................................................................................................................viii

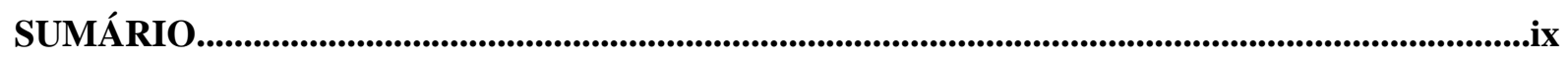

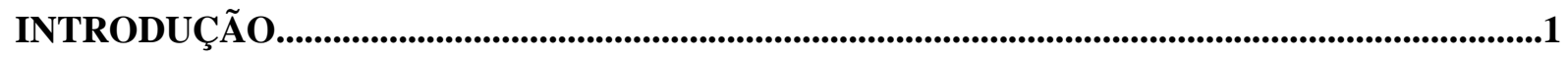

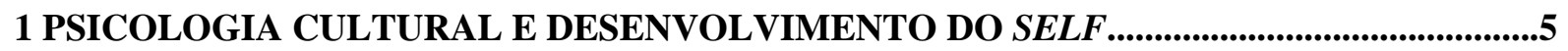

1.1 Cultura como parte inerente das funções psicológicas humanas...................................................5

1.2 Psicologia cultural: relação constitutiva entre cultura e processos psicológicos humanos 11

1.3 Dialogismo e desenvolvimento do sistema de self..................................................................11

1.4 Uma orientação afetiva no desenvolvimento do sistema de self.............................................15

2 JUVENTUDE: UMA EXPERIÊNCIA SUBJETIVA CANALIZADA

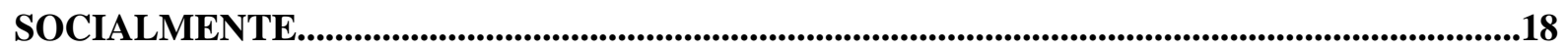

3 A EXPERIÊNCIA VOCACIONAL RELIGIOSA COMO CONTEXTO DE

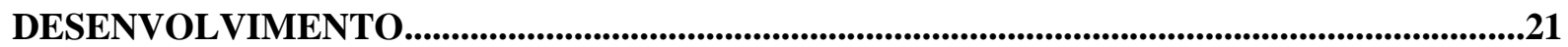

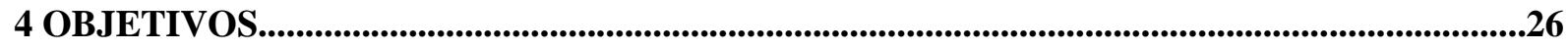

Objetivo Geral.......................................................................................................................................................26

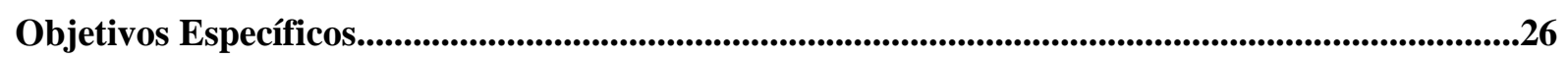

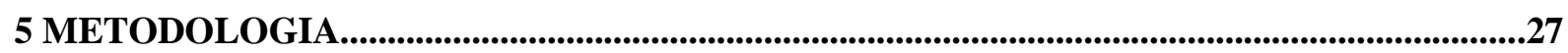

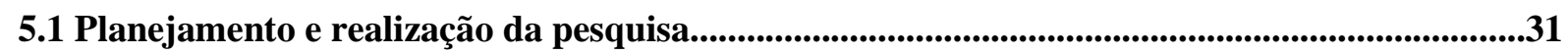

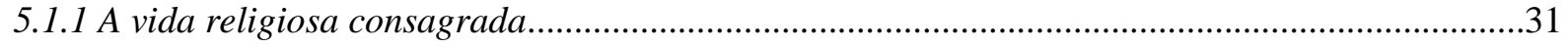

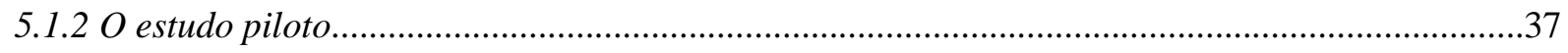

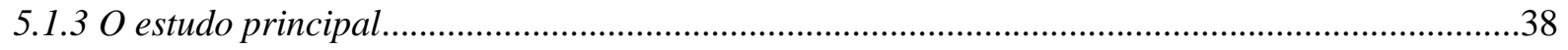

5.2 Procedimentos éticos na realização da pesquisa...............................................................................41

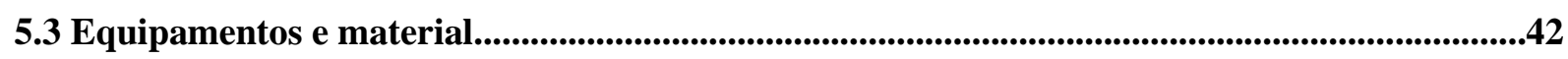

5.4 Procedimentos utilizados na organização e análise das informações............................................42

6 RESULTADOS E DISCUSSÃO.....................................................................................................44

6.1 Caso Cecília: a organização do sistema de self a partir do diálogo com as esferas de experiência.........................................................................................................................................................44

6.1.1 Momentos de entrevista e construção de informações ...................................................................4

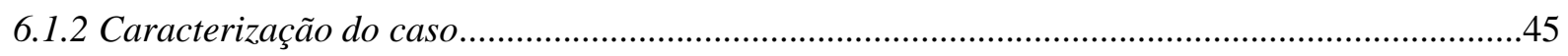

6.1.3 Movimentos semióticos e tensões dialógicas na trajetória de vida da Cecília...............................47

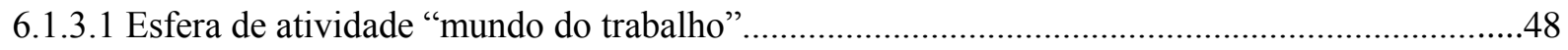

6.1.3.2 A emergência da posição "eu, vocacionada à vida religiosa consagrada".................................53

6.1.3.3 A esfera de experiência instituição religiosa: "no dia da tomada de hábito foi uma provação

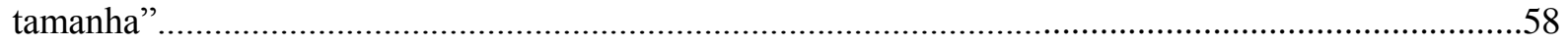

6.1.3.4 A mudança de nome: "hoje que eu estou entendendo o meu nome" ".........................................61 
6.2 Caso Fátima: a organização do sistema de self a partir do diálogo com recursos

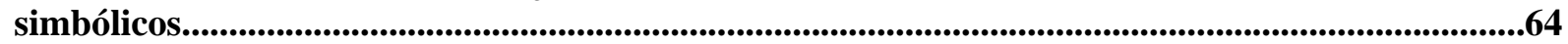

6.2.1 Momentos de entrevista e construção de informaçães ..................................................................64

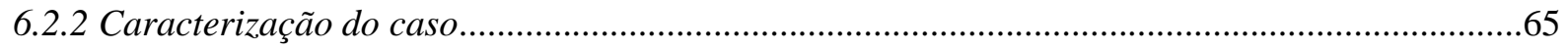

6.2.3 Movimentos semióticos e tensões dialógicas na trajetória de vida da Fátima................................66

6.2.3.1 A emergência da vocação religiosa: "eu não identificava que isso seria ser freira"..................68

6.2.3.2 A formação para a vida religiosa consagrada: "estava acostumada com Marta, de correr, correr

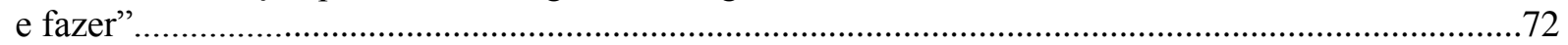

6.2.3.3 O hábito religioso: "naquele momento, foi o que me chamou atenção"....................................76

6.2.3.4 A consagração religiosa: "agora eu entendi que a vida consagrada é o dia a dia".....................81

6.3 Caso Francisco: a organização do sistema de self na zona de fronteira entre o dentro e o fora

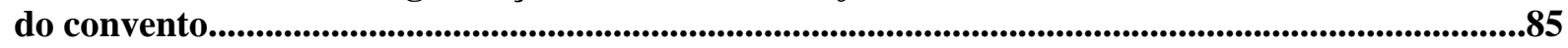

6.3.1 Momentos de entrevista e construção de informaçães .................................................................85

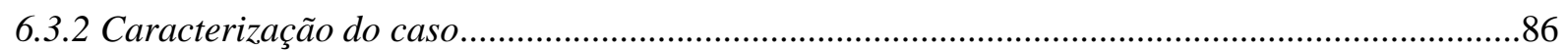

6.3.3 Movimentos semióticos e tensões dialógicas na trajetória de vida do Francisco...........................87

6.3.3.1 Uma leitura da vocação religiosa mediada pela condição de saúde.............................................89

6.3.3.2 A experiência no novo instituto de vida consagrada................................................................95

6.3.3.3 A vivência da vocação como professo simples......................................................................99

6.4 Caso Vicente: a organização do sistema de self a partir do diálogo com projetos em

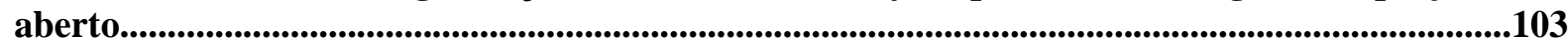

6.4.1 Momentos de entrevista e construção de informaçães ..................................................................104

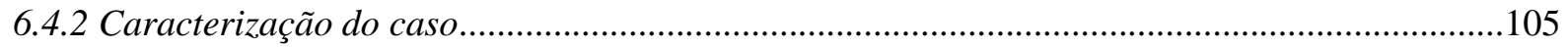

6.4.3 Movimentos semióticos e tensões dialógicas na trajetória de vida do Vicente............................105

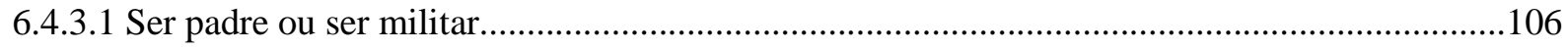

6.4.3.2 Ajustamentos entre tempo institucional e tempo cultural-pessoal...........................................113

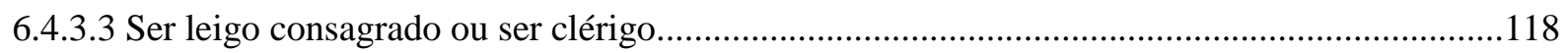

6.5 Desenvolvimento de sistemas de self em diálogo com futuros imaginados: o conceito teóricoanalítico de Horizontes de Projeção de Self .............................................................................125

6.6 Devolutiva em processo aos participantes............................................................................................128

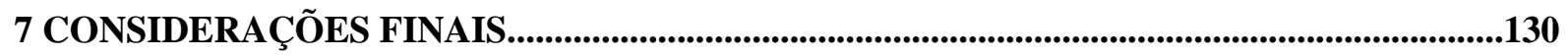

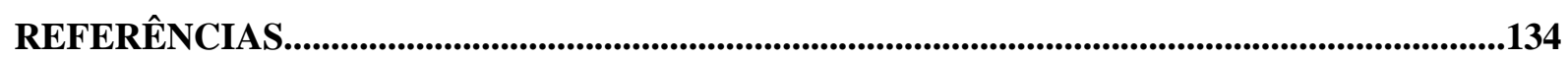

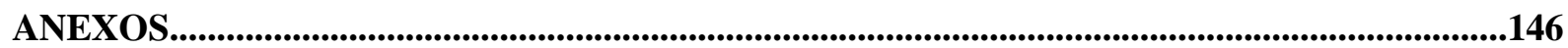




\section{LISTA DE FIGURAS}

Figura 1. Complexo Semiótico Relacionado ao Futuro Profissional da Cecília . .50

Figura 2. Complexo semiótico relacionado ao futuro vocacional: "bastava pra eu olhar minha vida com outros olhos".

Figura 3. Complexo semiótico orientador na ressignificação da tomada de hábito.. 60

Figura 4. Complexo semiótico relacionado ao ser padre... 109

Figura 5. Possibilidades de trajetórias vividas antes de ingressar no noviciado. 121

Figura 6. Complexo semiótico: "ser leigo consagrado X ser clérigo" 122

Figura 7. A regulação semiótica no fluxo de experiência para o futuro 126

\section{LISTA DE QUADROS}

Quadro 1 - Participantes do estudo principal .39

\section{LISTA DE ANEXOS}

ANEXO I - Aceite Institucional 146

ANEXO II - Termo de Consentimento Livre e Esclarecido. 148

ANEXO III - Termo de Autorização para Utilização de Imagem e Som de Voz para fins de pesquisa.

ANEXO IV - Guia de evocação de narrativas escritas.

ANEXO V - Roteiro de entrevista do tipo história de vida.

ANEXO VI - Roteiro de entrevista do tipo episódica utilizado com a jovem Cecília. 156

ANEXO VII - Roteiro de entrevista do tipo episódica utilizado com a jovem Fátima.

ANEXO VIII - Roteiro de entrevista do tipo episódica utilizado com o jovem Francisco .158

ANEXO IX - Roteiro de entrevista do tipo episódica utilizado com o jovem Vicente. 


\section{INTRODUÇÃO}

O presente trabalho surgiu de um interesse pessoal nos processos de transição de desenvolvimento em diálogo com esferas específicas de experiência. Em pesquisa anterior, que resultou na minha dissertação de mestrado (Araújo, 2008), investiguei concepções de desenvolvimento humano e de adolescência no contexto de um projeto socioeducativo voltado para crianças e adolescentes em situação de vulnerabilidade social. Na ocasião, as discussões foram organizadas em dois eixos de significação: 1. concepções de desenvolvimento humano e de adolescência construídas pelos profissionais responsáveis pela instituição; e 2. concepções sobre as mesmas temáticas construídas pelos adolescentes participantes do projeto. Os resultados possibilitaram reflexões sobre negociações entre expectativas pessoais e socioinstitucionais, especialmente nas trajetórias de desenvolvimento dos adolescentes.

Também a minha atuação profissional como professor no ensino fundamental II, de 2000 a 2013; como coordenador e orientador pedagógico no ensino fundamental e médio, de 2011 a 2013; como professor em cursos de pedagogia e psicologia; e como coordenador executivo em um curso de extensão para conselheiros tutelares do estado de Goiás (2011) tornou-se espaço privilegiado de reflexões sobre o papel de esferas específicas de experiência na canalização de processos de desenvolvimento, tornando direções potencialmente mais prováveis que outras. Com tais inquietações, regressei à academia em 2013, motivado a aprofundar no doutorado o estudo sobre condições de desenvolvimento negociadas dialogicamente entre a pessoa e a cultura.

No doutorado, o foco se deslocou da adolescência para a condição juvenil, e do âmbito da educação não formal para uma modalidade de educação formal, embora não convencional: a formação de jovens católicos para a vida religiosa consagrada. $\mathrm{O}$ desenho do projeto de pesquisa resultou do seguinte conjunto de interesses e justificativas sociais e acadêmicas:

1. Do ponto de vista da psicologia cultural, o sistema de self resulta dos processos de construção de significado (Bruner, 1987). O sujeito se constitui mediante relações entre significados coletivos e pessoais - ambos, em maior ou menor grau, orientados por sistemas simbólicos, ofertados culturalmente. As culturas possuem representações dinâmicas do sentido de pessoalidade, e "nós também nos tornamos variantes das formas culturais canônicas" (Bruner, 1987, p. 15).

2. Diferentes representações do ser jovem também são encontradas na cultura, de modo que condições juvenis são interpretadas e negociadas no encontro entre indivíduo e cultura. Os jovens constroem histórias sobre si com base em narrativas socialmente disponíveis ou negadas. E, assim, narrativas coletivas e pessoais atuam como ferramentas na organização de uma experiência inteligível e atualizada do ser jovem. Isso faz do desenvolvimento 
juvenil uma experiência pessoal delimitada por paisagens sociais, econômicas e históricas (Zittoun, 2007a, 2007b).

3. A pluralidade do desenvolvimento juvenil vem sendo reconhecida nas diferenças e desigualdades que marcam a experiência social dos jovens. Questões de gênero, cor/etnia, classe social, escolaridade, local de moradia, inserção no mundo do trabalho, gostos e estilos, bem como participação em grupos são exemplos das configurações distintas do sentir-se jovem. De modo similar, o sentir-se vocacionado para a vida religiosa consagrada direciona importantes negociações no sistema de self ao longo da trajetória de vida da pessoa.

4. Apesar de a discussão dos processos de desenvolvimento na juventude ter aumentado nos últimos anos em diferentes áreas do conhecimento, a condição juvenil ainda é pouco investigada, especialmente do ponto de vista das transições de desenvolvimento vividas no plano subjetivo (Mattos, 2013). Por sua vez, a religiosidade, como contexto de subjetivação de experiências do ser jovem, também tem recebido pouca visibilidade (Godinho, 2007; Martins \& Carvalho, 2013), em particular na perspectiva semiótico-cultural. E, por serem pouco enfocadas, trajetórias de jovens em conventos, mosteiros e outros contextos religiosos tornam-se socialmente invisíveis.

5. A investigação de processos de desenvolvimento juvenil nos contextos da vida religiosa consagrada católica pode abrir novos horizontes de reflexão sobre a relação entre pessoa e instituição. Colocam-se em diálogo atitudes que costumam ser associadas à juventude como liberdade de pensamento e de expressão, questionamento, busca por independência - e o rigor exigido pelos institutos de vida consagrada, com base em ideários de pobreza, castidade e obediência.

6. Experiências e cortes de desenvolvimento peculiares, tais como o investigado neste trabalho, encontram-se entre os objetos de interesse do grupo de pesquisa do nosso Laboratório de Psicologia Cultural, onde o enfoque das interfaces entre desenvolvimento pessoal e sociocultural, em diferentes cenários institucionais, é uma tônica.

7. Por fim, considerando minha própria trajetória de desenvolvimento, a investigação figura como uma contribuição pessoal a esse contexto institucional, do qual fiz parte, como candidato à vida religiosa consagrada, entre 1997 e 2000.

Nesse sentido, o estudo contribui no aprofundamento teórico-metodológico da noção de desenvolvimento, particularmente na investigação de transições de desenvolvimento e mudanças no sistema de self juvenil. Colabora, ainda, com reflexões importantes sobre o constituir-se jovem na contemporaneidade, dentro ou fora do contexto formativo para a vida religiosa consagrada.

Este estudo, de caráter longitudinal e teórico-empírico, tem como ponto de partida e princípio compreensivo da realidade psicológica a relação dialógica entre experiência pessoal e 
coletiva. Aborda transições psicossociais de jovens católicos, vocacionados à vida religiosa consagrada, numa valorização das experiências e dos contextos vivenciados em diálogo com expectativas e futuros imaginados.

Os três primeiros capítulos do trabalho delineiam os fundamentos teóricos e conceituais que orientam as análises e interpretações do estudo. O primeiro capítulo apresenta fundamentos da psicologia cultural que sustentam a discussão dos processos de desenvolvimento do self. O segundo capítulo, considerando o fenômeno juventude como uma experiência subjetiva canalizada socialmente, discute processos de transição juvenil articulados com uma perspectiva culturalista do desenvolvimento. O terceiro capítulo debate a experiência vocacional religiosa como um contexto de desenvolvimento, canalizador de modos de ser e de sentir do sujeito.

Tendo a experiência vocacional religiosa como pano de fundo para a interpretação das informações construídas em relação aos jovens, o estudo teve como objetivo geral investigar, numa perspectiva semiótico-cultural, transições de desenvolvimento e sistema de self à luz da experiência de jovens em formação para a vida religiosa consagrada. Dessa forma, ganhou destaque a transição de desenvolvimento em direção ao tornar-se religioso consagrado, em diálogo com esferas de experiência e recursos simbólicos que desempenham papel constituinte e regulador no sistema de self da pessoa.

A investigação foi desenvolvida nas fronteiras de uma epistemologia qualitativa, onde conhecer é construir informações situadas em um tempo e espaço social, histórico e cultural - o desafio de interpretar realidades sociais como sistemas simbólicos, processos históricos, sistêmicos e contextualizados. Foram conduzidos quatro estudos de caso de jovens em formação para a vida religiosa consagrada, com idades entre 19 e 25 anos, prestes a vivenciar ou vivenciando a etapa de formação intitulada noviciado. Neste estudo, o noviciado representou uma transição psicossocial significativa na discussão do sistema de self, visto que, ao final desse período, os jovens professariam os votos religiosos de pobreza, castidade e obediência, passando a ser reconhecidos como consagrados.

Os resultados possibilitaram análises de transições juvenis orientadas culturalmente e interpretadas de modo singular pelos sujeitos. Os valores cristãos assumiram papel regulador na construção de futuros imaginados, num processo de singularização, dentro de limites e possibilidades ofertados socialmente. E a experiência formativa para a vida religiosa consagrada favoreceu processos de internalização e externalização, movimentando zonas de fronteiras semióticas na organização do sistema de self e na construção de Horizontes de Projeção de Self (HPS) pelo sujeito.

O conceito de HPS, proposto neste trabalho, resulta de um esforço teórico de construir um modelo abstrato que contribua na compreensão do modo como a orientação para o futuro passa a integrar o sistema de self - ou deixa de fazê-lo. Ao longo da trajetória de vida, os jovens 
experimentam transições psicossociais acompanhadas de tensões dialógicas entre significados pessoais e socioinstitucionais. Esses desafios colocam em diálogo experiências vividas e imaginadas, facilitando ou dificultando o desenvolvimento de um sentido de continuidade de si. Assim, ao desempenharem papel fundamental na ampliação das fronteiras do sistema de self, os HPS contribuem com vivências singulares tanto das condições juvenis ofertadas culturalmente quanto da passagem para a condição de adulto.

É nessa perspectiva que este estudo colabora na compreensão de processos de transição de desenvolvimento juvenil, destacando movimentos semióticos no sistema de self dos jovens em diálogo com expectativas, esferas de experiências e recursos simbólicos, na irreversibilidade do tempo. 


\section{PSICOLOGIA CULTURAL E DESENVOLVIMENTO DO SELF}

A presente pesquisa investiga processos de transição juvenil, tomando por base uma perspectiva que se afigura como cultural, dialógica, histórica, social e psicológica. O estudo parte da premissa de que é em meio a uma cultura que, dialogicamente, emergem a condição humana, a linguagem e o conhecimento. Portanto, torna-se fundamental entender o contexto sociocultural que possibilita à pessoa um diálogo com crenças e valores construídos historicamente nas interações sociais.

\subsection{Cultura como parte inerente das funções psicológicas humanas}

O conceito de cultura, não raramente, apresenta divergências entre estudiosos. Contudo, segundo Santos (1996), as variadas maneiras de entender o que é cultura localizam-se em duas concepções básicas: uma que destaca os aspectos de uma realidade social e outra que, de modo mais específico, destaca conhecimentos, ideias, crenças e valores de um grupo. Esses são apenas dois modos de dar ênfase ao estudo da cultura, visto que falar da maneira como as pessoas existem na sociedade, suas crenças e valores, nos exige considerar a presença de uma totalidade social.

Segundo Geertz (1978), a cultura pode ser representada como "teias" de significados, coconstruídos de forma complexa e dinâmica, e compartilhados ativamente por participantes de uma comunidade, de um grupo. Assim, esse autor defende o conceito de cultura como

essencialmente semiótico... o homem é um animal amarrado a teias de significados que ele mesmo teceu, assumo a cultura como sendo essas teias e a sua análise; não como sendo uma ciência experimental em busca de leis, mas como uma ciência interpretativa, à procura do significado (p. 15).

Também para Bruner (2001), a cultura se configura como um sistema simbólico: "é um conjunto de ferramentas com técnicas e procedimentos" (p. 98) que, mediante seus significados num dado contexto, auxiliam o indivíduo a entender e lidar com o mundo material e simbólico. A cultura familiar, a cultura escolar, a cultura da comunidade mais ampla, bem como as culturas juvenis, são "fios" que, "amarrando" o sujeito, o colocam em diálogo com crenças e valores construídos historicamente no contexto social (Valsiner, 2000, 2009). É na relação com a cultura que se torna possível instituir, interpretar e transformar normas, valores e saberes (Bruner, Goodnow, \& Austin, 1956; Correia, 2003; Rogoff, 1998). 
O conceito de cultura que perpassa por este estudo é essencialmente semiótico (Geertz, 1978), ou seja, é memória não genética, informações acumuladas e transmitidas mediante processos de interação social, como a religião, a arte e o direito (leis), resultando em uma "teia" como um continuum semiótico sobre o qual as relações cotidianas emergem e se organizam (Velho, 2009). Compreendida como uma criação humana, a cultura está sempre em transformação e, portanto, deve ser vista como um sistema dinâmico e aberto (Esteban-Guitart, 2008). Suas instituições, leis e valores funcionam como um conjunto de ferramentas materiais e simbólicas que orientam processos de internalização e externalização de significados. Tais ferramentas fornecem um campo de ação, valoração moral, pensamento e afetividade, guiando condutas e possibilitando o entendimento de experiências coletivas e pessoais (Rosa, 2000).

A cultura não é apenas o que está fora, presente no campo social, mas é "parte inerente das funções psicológicas humanas" (Valsiner, 2012, p. 33). E a vida mental é uma construção interdependente do aparato cultural vivenciado e interpretado pelo sujeito. É em meio às sugestões culturais que, num tempo irreversível, a consciência se expressa, cria e recria signos, orientada por várias instituições sociais.

Para além dos objetos, dos costumes, dos comportamentos e das atitudes, a cultura envolve expressões humanas, carregadas de significados e estruturadas discursivamente em sintonia com um contexto histórico (Serrano, 1996). Essas expressões são produzidas e transmitidas em contextos e sistemas de atividades específicas, onde membros de um grupo cultural compartilham não só objetos, mas também crenças e valores. $\mathrm{E}$ os elementos da cultura funcionam como ferramentas semióticas que dinamicamente medeiam a construção de suas funções psicológicas superiores (Vygotsky, 2007). A partilha de significados está na base do desenvolvimento cultural, bem como no desenvolvimento do sujeito como sujeito ativo e situado.

A cultura é entendida como símbolos compartilhados, conceitos, significados, práticas que definem unidades culturais e são gerados por elas, tais como a família, o bairro, uma comunidade ou um país. Nesse sentido, entendemos "cultura" como formas implícitas e explícitas compartilhadas por uma unidade cultural - formas tácitas, "dadas por supostas", de acreditar, pensar e agir, na dimensão implícita; e artefatos culturais, como a leitura e os livros ou os times de futebol e as bandeiras, na dimensão explícita (Esteban-Guitart, 2008, p. 10, tradução nossa).

Porém, essa partilha de sentidos e significados nem sempre se dá livre de tensões e resistências. Há uma constante "tensão irredutível" entre o sujeito, ativo em seu agir, e o ambiente, isto é, tudo aquilo que o envolve: pessoas, objetos, símbolos, valores morais (Wertsch, 1998). No pensamento de Wertsch, estabelece-se uma relação contraditória entre continuidade e mudança na (re)construção dos significados e dos valores culturais pela pessoa. 
Uma concepção processual e dinâmica de cultura apresenta como fundamento uma ideia de relação constitutiva entre ambiente e pessoa. Nessa relação, o contexto cultural dispõe de ferramentas simbólicas que funcionam como próteses na ampliação dos recursos psicológicos do sujeito, permitindo-lhe regular e orientar seu estar no mundo, amenizando algumas de suas limitações biológicas (Geertz, 1978; Valsiner, 1989) e criando outras simbólicas. Portanto, a consciência individual deve ser compreendida para além de termos unicamente cognitivos e intelectuais. Sua constituição também é mediada pela afetividade, pelas emoções, pelos desejos e pelas motivações que canalizam a ação humana em um mundo de significados (Branco \& Valsiner, 1997).

A relação entre cultura e desenvolvimento das funções psicológicas humanas traz para a reflexão a noção de canalização cultural. A canalização cultural refere-se aos limites e incentivos, ou às possibilidades, físicos e semióticos que atuam nos processos relacionais entre indivíduo e contexto social (Branco, 2006; Madureira \& Branco, 2005; Valsiner, 1987, 1998). Trata-se de uma força que atua de forma conjunta, às vezes antagônica, com a intencionalidade inerente ao sujeito (Branco \& Valsiner, 1997; Cole, 1995; Valsiner, 1987, 1989; Werstch, 1991, 1998). Portanto, a canalização cultural opera em interação com a intrínseca participação ativa do sujeito, em uma relação coconstrutiva dos fenômenos sociais e humanos, e de modo simultâneo à indeterminação inerente aos processos de desenvolvimento dos sistemas abertos. Esse processo está na gênese de novos padrões de desenvolvimento, novos valores e novas crenças nos contextos socioculturais (Branco \& Mettel, 1995; Palmieri \& Branco, 2004). Assim, a participação constitutiva da cultura nos processos psicológicos se mostra como premissa central da psicologia cultural, tema a ser discutido a seguir.

\subsection{Psicologia cultural: relação constitutiva entre cultura e processos psicológicos humanos}

A perspectiva culturalista do desenvolvimento humano nos remete às ideias de Lev Semyonovich Vygotsky (1896-1934), primeiro autor a dar destaque à origem social do funcionamento mental (Vygotsky, 2007). As ideias de Vygotsky nos exortam a compreender o indivíduo olhando para fora dele, ou seja, para sua cultura. Assim, na busca pela compreensão do desenvolvimento humano, sobressaem as interações estabelecidas entre pessoa e ambiente, relações sociais e históricas que canalizam a existência humana.

Para Vygotsky, a dimensão social da consciência é primária e a dimensão individual é derivada e secundária (Wertsch \& Tulviste, 1994). O desenvolvimento da pessoa aparece em dois planos: primeiro no plano social e, depois, no plano psicológico (Vygotsky, 2007), isto é, primeiro 
entre as pessoas, numa dimensão interpsicológica, e depois como função internalizada, numa dimensão intrapsicológica. Nesse processo, significados, crenças e valores são internalizados pelo sujeito de maneira pessoal e ativa, mediante as relações com a cultura. Isso resulta, num tempo irreversível, em novas reorganizações e transformações das estruturas e funções mentais. Essa perspectiva orienta um olhar dialético de termos como cognição, memória, pensamento, atenção, linguagem, identidade e sentidos de si, que devem ser "entendidos não como atributos ou propriedades do indivíduo, mas como funções que podem ser realizadas inter ou intramentalmente" (Wertsch \& Tulviste, 1994, p. 336).

Vygotsky (2000) analisa as funções da linguagem na mesma perspectiva da origem social do funcionamento mental. Ele destaca o discurso interior como uma fala egocêntrica que possibilita ao ser humano planejar e regular seu agir no mundo, e que resulta de participações do sujeito em interações sociais. É o discurso internalizado, mediado por um discurso externo e anterior, que possibilita novas organizações discursivas, novas regulações da ação e novas perspectivas. Estas se fazem em constante tensão com a realidade e podem estar, ou não, em conformidade com as sugestões e os contextos socioculturais dos quais o sujeito participa. Assim, como um sistema de signos, a linguagem inicialmente é usada com o intento de afetar o outro. Depois, ao ser internalizada, torna-se uma ferramenta pessoal, afetando o sujeito e configurando o seu sentir e agir no mundo.

Também fundamentada numa abordagem histórico-cultural, a psicologia cultural vem sendo esculpida dentro de uma variedade de versões, algumas delas denominadas "culturais" apenas em virtude da centralidade da palavra "cultura" em suas discussões (Valsiner, 2007, 2009), confundindo-se com versões da psicologia social e da própria antropologia. O que é específico da psicologia cultural de base semiótica? Como subárea da psicologia, a psicologia cultural visa compreender os fenômenos psicológicos, vistos como processos dinâmicos que ocorrem na fronteira entre o pessoal e o cultural, contribuindo com a superação de visões estáticas de desenvolvimento humano. O adjetivo "cultural" ressalta o caráter relacional e culturalmente enraizado de tais fenômenos psicológicos. Na sua curta história, desde a década de 1990, são vários os estudiosos que se identificam com a psicologia cultural semiótica (Branco \& Valsiner, 1997; Bruner, 1997; Cole, 1996; Kitayama \& Cohen, 2007; Rogoff, 2003; Rosa, 2000; Valsiner, 2012; Valsiner \& Rosa, 2007; Wertsch, 1991; Zittoun, 2012). Com algumas particularidades, eles compartilham a ideia de que "o objetivo da psicologia cultural é compreender como os processos de desenvolvimento humano têm lugar na cultura" (de la Mata y Cubero, 2003, p. 185, tradução nossa).

São publicações e nomes importantes nos primórdios da psicologia cultural: Jerome Bruner (1997); Michael Cole, com a publicação do livro Cultural psychology: a once and future discipline (1996); Shinobu Kitayama e Dav Cohen, que organizaram o primeiro Handbook of cultural 
psychology (2007), além de Jaan Valsiner, que organizou The Oxford handbook of culture and psychology (2012) e, em parceria com Alberto Rosa, The Cambridge handbook of sociocultural psychology (2007). Da mesma forma, a psicologia cultural tem recebido contribuições importantes por parte de outros autores, como Richard Shweder (1990), Ernst Boesch (1997), Branco e Valsiner (1997), James Wertsch (1991), Bárbara Rogoff (2003), Pablo del Río e Amelia Álvarez (2007), Alberto Rosa (2000) e Ignasi Vila (2001).

A psicologia cultural questiona toda ênfase dada aos contextos socioculturais divorciada de um enfoque nas relações dialéticas entre universal e particular. Ela ressalta os aspectos diferenciais do funcionamento mental, buscando superar as críticas aos modelos de psicologia cognitiva e psicologia transcultural. O primeiro pecou por se tornar uma abordagem fragmentada e tecnicista, perdendo de vista a investigação do significado, defendido por Bruner (1997) como um conceito central na investigação psicológica. E o segundo, o modelo de psicologia transcultural, apesar de partir da ideia de cultura como diferentes contextos de desenvolvimento e discutir comportamentos e práticas inseridos nesses contextos, acaba por limitar-se à validação de hipóteses transportadas para culturas diversas, explorando e focando variações culturais na intenção de construir conhecimento sobre processos universais (Rogoff \& Chavajay, 1995). Assim, esses dois modelos acabaram por sustentar uma ideia de cultura como um termo descritivo e os processos cognitivos como capacidades globais, sugerindo uma pretensa homogeneidade entre os membros de uma cultura e mostrando-se ambos limitados para pensar o papel da cultural na construção dos processos psicológicos (Pérez \& Santigosa, 2005; Valsiner, 2012).

A psicologia cultural considera a posição ativa do sujeito nos contextos sociais, buscando compreender o papel de ambientes físicos e simbólicos na sua constituição (Valsiner, 2007). Ela questiona uma antiga contradição presente nas ciências humanas, inclusive na própria psicologia: uma ênfase na importância dos contextos culturais para o desenvolvimento humano, contrastando com um lugar secundário reservado ao papel da cultura na construção da vida mental do sujeito (Pérez \& Santigosa, 2005). Uma parcela significativa de trabalhos empíricos ainda é desenvolvida dentro de uma metodologia que nem apresenta ou, quando o faz, desconsidera as recentes inovações das discussões sobre a cultura como parte constitutiva dos processos psicológicos (Valsiner, 2007, 2009). Assim, "a principal função das teorias — serem ferramentas intelectuais para a compreensão - facilmente se perde" (Valsiner, 2009, p. 7). A teoria reduz-se à repetição do já dito, sem avanço e inovação consistentes.

Como subárea da ciência psicológica, a psicologia cultural é uma disciplina em desenvolvimento, um campo de interesse internacional, estando sua exploração interdisciplinar em ascensão (Valsiner, 2009). Ela partilha do desafio de responder a questões relativas à adaptação de procedimentos de pesquisa empírica, por meio de métodos que considerem as características próprias dos sistemas abertos. Para Valsiner (2009), a psicologia cultural ainda precisa 
contextualizar melhor seu objeto de pesquisa, pois, apesar de o foco no contexto ser sua premissa central, ainda ocorre uma compreensão relativamente limitada do que seja o contexto - uma visão restrita ao aqui e agora, negligenciando, assim, uma "contextualização do contexto", com o antes e o depois do momento presente.

Ao destacar processos de construção, ressignificação e uso de signos, a psicologia cultural torna o estudo da subjetividade um aspecto fundamental do desenvolvimento humano (Valsiner, 2012). É por meio desses processos que novos fenômenos psicológicos emergem, em uma constante fabricação de significados para compreender e relacionar a pessoa com o contexto sociocultural. Mente e cultura se constituem numa separação inclusiva, vistos como gênese e produto um do outro (Abbey, 2012; Bruner, 2002; Cole, 1995; Valsiner, 2006, 2007, 2009; Vygotsky, 2007).

O conceito de separação inclusiva tem papel fundamental no reconhecimento da relevância dos contextos na investigação dos fenômenos humanos no campo da psicologia cultural (Valsiner, 1997, 1998; Valsiner \& Cairns, 1992). Segundo esse conceito, embora na pesquisa a ênfase seja sobre o fenômeno em estudo, este não é separado de seus contextos, e os contextos, como parte constitutiva do processo, não são eliminados (Valsiner, 1997). A estratégia de separação inclusiva sustenta perspectivas que fundamentam a compreensão do psicológico numa relação mediada pela cultura.

Por serem essencialmente relacionais, os processos de mediação cultural devem ser pensados segundo uma dinamicidade própria dos sistemas abertos. Deve-se considerar, outrossim, sua interdependência em relação aos contextos sócio-históricos, como processos que acontecem em certo enquadramento espacial e em um movimento dialético num tempo irreversível - presente, passado e futuro (Cole, 1995). Nesse sentido, a vivência do presente, mediada pelas experiências do passado e pela antecipação e imaginação do futuro, cria condições e possibilidades para a realização de perspectivas. Em tal processo, os signos detêm função central e papéis que vão da mediação à regulação da experiência humana, sugerindo campos de ação para o sujeito (Valsiner, 2002, 2004, 2012).

Uma das vias de desenvolvimento e priorização de uma abordagem de mediação na psicologia cultural (Valsiner, 2009) tem tido como foco ferramentas culturais ou recursos simbólicos (Zittoun, 2006a, 2006b, 2007a, 2007b). Compreende-se como recursos simbólicos "elementos culturais utilizados por uma pessoa, a fim de fazer alguma coisa, isto é, com alguma intenção que pode ser mais ou menos flexível" (Zittoun, 2007b, p.14, tradução nossa). Assim, ouvir uma música para se sentir mais perto de um ente querido é usar um elemento cultural como um recurso simbólico - assim como esforçar-se por construir significados em busca de ajustamentos entre pessoal e institucional, mediante orientações e estratégias pedagógicas na formação para a vida religiosa consagrada. A mediação refere-se à introdução, em uma relação originalmente 
binária, de um terceiro elemento que acaba por ter um papel transformador. Passa-se a exigir a presença de um "eu", de um "outro" e de signos que medeiam a relação (Salgado \& Ferreira, 2012).

Como instrumentos simbólicos, os signos medeiam a relação sociocultural de cada interlocutor consigo mesmo e com o outro. E é no processo de dar significado às próprias experiências que o sujeito contrói hierarquias de valores (Valsiner, 2009, 2012). Essas hierarquias não são fixas. Sofrem transformações, visto que alguns sentidos que hoje são mais estáveis para o sujeito podem, no futuro, se tornar menos estáveis e circunscritos a determinadas situações. Da mesma forma, sentidos criados podem ser abandonados em um momento posterior do desenvolvimento (Valsiner \& Van Der Veer, 2000).

\subsection{Dialogismo e desenvolvimento do sistema de self}

O dialogismo é essencial para compreender a formação e transformação da realidade social e psicológica. A parte mais expressiva dos processos humanos - sejam os identitários, os cognitivos, ou os relativos aos posicionamentos morais ou à construção de significados — não é natural, mas possui uma gênese relacional. Sua principal característica, desse modo, é a constante mutabilidade, uma (re)construção interdependente dos contextos socioculturais.

O sujeito só existe na relação com o outro. E a mente humana é resultado da constante relação da pessoa com o ambiente, não apenas na ontogênese do sujeito, mas também entre as gerações precedentes, ao longo da filogênese. As ações e os pensamentos só fazem sentido quando se considera a sociabilidade como pano de fundo (Ferreira, Salgado \& Cunha, 2006; Marková, 2003).

Segundo o pensamento bakhtiniano $(1981,1997)$, a gênese do nosso pensamento bem como suas constantes transformações resultam das sucessivas interações com outros pensamentos. Nós resistimos à fala do outro, nos apropriamos dela e a ressignificamos de modo criativo. Assim, nossos discursos são repletos de outros discursos, nossas falas são mestiças, e nossas vozes, povoadas por vozes "estrangeiras". Não podemos nos expressar nem nos posicionar sem considerarmos outros enunciados, outras vozes. Nesse processo relacional, nossas perspectivas pessoais são construídas e, constantemente, ressignificadas na resistência e na aceitação de outros pontos de vista.

É na relação com o outro que se dá a existência de si: existir implica relacionar-se, "ser é comunicar" (Bakhtin, 1984, p. 287). Ao nos posicionarmos em relação ao outro, nos comunicamos e construímos sentido para nossa existência pessoal. Portanto, não há construção de sentido nem 
relação humana que não sejam dialógicas (Bakhtin, 1981, 1997; Fogel, 1993; Hermans, 2002; Hermans \& Kempen, 1993; Valsiner, 1989, 2012). Antes da transmissão ou troca de mensagens, o que ocorre é um encontro de significados no nível relacional.

A perspectiva dialógica, com ramificações em diversas escolas de pensamento, "enquanto teoria de compreensão e estudo da identidade, é herdeira dos modelos construtivistas nas ciências sociais e na psicologia" (Rosa \& Gonçalves, 2013, p. 305). Nesta última, o dialogismo tem sido utilizado para uma releitura de processos de desenvolvimento do sujeito: "um sujeito social que, inserido na memória e na história, não pode ser concebido fora das relações com um outro, compreendido como constitutivo tanto do sujeito quanto das identidades" (Dominguez, 2013, p. $11)$.

Nesta relação, considerar como intrínsecas as concretas condições culturais, sociais e históricas em que os sujeitos interagem é reconhecer o caráter relacional da ação pessoal. O sujeito não age individualmente, mas ancorado em expressões do grupo (Dominguez, 2013; Hermans, 2002; Valsiner, 1989, 2009, 2012). Logo, investigar o desenvolvimento do indivíduo na perspectiva dialógica exige destacar o caráter contextual, situado, complexo e dinâmico da construção subjetiva. E a Teoria do Self Dialógico (Hermans, Kempen, \& van Loon, 1992), a concepção de self narrativo do Bruner (2002) e as discussões de Wiley (1994) sobre o self como sistema semiótico são exemplos de perspectivas dialógicas do desenvolvimento desse sistema que integra a cultura pessoal, resultante de incidências da cultura grupal sobre o indivíduo.

A abordagem teórica do self dialógico tem como marco histórico a publicação do artigo "The dialogical self: beyond individualism and rationalism", por Hermans, Kempen e van Loon, em 1992, no periódico American Psychologist. Os autores, que provêm da prática profissional em psicoterapia, desenvolveram essa abordagem como resposta à visão individualista e racionalista do eu, então dominante no seu campo de atuação. Esse modelo fundamentou-se, de modo particular, no pensamento de William James (1842-1910) e na noção de polifonia de Bakhtin (1895-1975), além de considerar elementos do pensamento da psicologia russa e do interacionismo simbólico de George Herbert Mead (1863-1931) e da escola de Chicago.

Ao longo das duas últimas décadas, diferentes pesquisadores têm contribuído com o desenvolvimento teórico e metodológico da teoria do self dialógico (Bertau \& Gonçalves, 2007; Cunha, Salgado \& Gonçalves, 2012; Fogel, Koeyer, Bellagamba, \& Bell, 2002; Freire, 2008; Gonçalves \& Ribeiro, 2012; Lopes de Oliveira, 2013, 2016; Lyra, 2007; Mattos \& Chaves, 2013; Padilha, 2010; Roncancio-Moreno \& Branco, 2014; Rosa \& Gonçalves, 2013; Salgado \& Gonçalves, 2007; Simão, 2010). Tais contribuições apresentam uma ideia de pessoa constituída dinamicamente por múltiplas vozes (Bakhtin, 1984) que concordam e discordam entre si, se contradizem e se integram, configurando um sentido de si do sujeito narrativamente estruturado, em uma paisagem imaginária (Hermans, Kempen, \& van Loon, 1992). São características dessa 
abordagem a ênfase tanto no espaço como no diálogo entre as posições que garantem o caráter múltiplo do self.

O trabalho seminal de Hermans, Kempen e van Loon é apresentado aproximadamente na mesma época em que Bruner (2002) publica sobre o self narrativo, que também enfatiza os sistemas de significados culturais. Para esse autor, o self se configura sob uma autoria do sujeito, que, situado em uma cultura, num espaço temporal, interconecta presente, passado e futuro. Assim, os sentidos de si são construídos de modo inovador pelo sujeito, a partir de sugestões culturais em constante transformação. E em diálogo com narrativas sociais o sujeito constitui uma versão dinâmica e pessoal de si.

A concepção de self narrativo de Bruner (2002) destaca uma continuidade do eu e, ao mesmo tempo, as constantes transformações decorrentes da experiência humana (Macedo \& Silveira, 2012). Assim, o mais importante na compreensão do self narrativo não é a continuidade, nem a mudança em si, mas as relações dialógicas que o sujeito estabelece com os contextos socioculturais e que lhe possibilitam mudanças ou continuidades singulares na construção narrativa de si.

Por sua vez, Wiley (1994) discute o self como sistema semiótico cuja configuração parte de um organismo, o corpo físico. A perspectiva semiótica defende o self como um processo resultante da assimilação de signos culturais. Ela se fundamenta no pensamento de Charles Sanders Peirce (1839-1914) e George Herbert Mead, autores clássicos do pragmatismo americano que apresentaram uma noção de self que buscava descentrar o self cartesiano.

Ao discutir sua concepção de self semiótico, Wiley retoma o self retrospectivo representado na distinção eu (presente) - mim (passado) de Mead e o coloca em diálogo com o self prospectivo representado na distinção eu (presente) - você (futuro) de Peirce. Assim, a dimensão temporal ganha destaque nessa discussão como processo inerente à geração de sentido, o "meaninggenerating process" (Wiley, 1994, p. 218).

Como processo constante de autointerpretação, o self semiótico está sempre em transformação. Ancorado num tempo presente, interpreta o passado em vias de um futuro, pois, "à medida que o self move-se através da linha do tempo, seu processo semiótico é constantemente transformado" (Wiley, 1994, p. 14). Variados processos de pensamento e experiências tornam a pessoa consciente de uma existência única, continuada, envolvendo uma representação mental de experiências pessoais. Investigar o self como sistema semiótico em constante ressignificação nos exige considerar as relações dialógicas entre as características permanentes e possivelmente universais, que fazem as pessoas iguais como seres humanos, e as constantes mudanças nos níveis filogenéticos e ontogenéticos, potencializadas pelas dinâmicas culturais (Gergen, 1985).

Visões dinâmicas do sistema de self (como a Teoria do Self Dialógico, o self narrativo e o self semiótico), fundamentadas numa perspectiva dialógica, apresentam um olhar mais integrado 
dos processos subjetivos (Branco, 2005; Gonçalves \& Salgado, 2001; Hall, 2002; Lewis, 2002; Lopes de Oliveira, 2006; Valsiner, 2002, 2012). Desse modo, o self é visto como um discurso que se configura socialmente, sendo constantemente negociado nas dinâmicas relações sociais (Josephs, 2002; Valsiner, 1987, 2000, 2002; Vygotsky, 2007). Como uma entidade teórica, o self "se organiza (existe) por meio de um processo de relações dialógicas entre seus componentes" (Valsiner, 2012, p. 127). Pessoas presentes ou distantes, que fizeram ou fazem parte de um contexto, experiências passadas e perspectivas futuras participam da configuração de posições num self multivocal (Hermans, Kempen, \& van Lonn, 1992). Nesse sentido, o ser humano não possui uma consciência soberana, "não é auto-suficiente, não existe apenas numa consciência. Antes é "dotado de uma consciência essencialmente plural e conflitual, o homem, ao ser para o outro, é para si" (Germano \& Bessa, 2010, p. 1006).

Considerando a interdependência entre organismo e ambiente, a tarefa de investigação do sistema de self é processual e exige evidenciar a complexidade das relações semióticas, possibilitadas pelos contextos socioculturais. Algumas transformações biológicas e sociais vividas no momento da adolescência e juventude, por exemplo, são potencialmente promotoras de processos de desenvolvimento que transformam o autoconceito dos sujeitos. Porém, essas mudanças não acontecem no mesmo ritmo para todos os sujeitos nem são evidenciadas com o mesmo significado e importância nas diferentes culturas. E o sujeito, canalizado por um contexto sociocultural heterogêneo, desenvolve um modo pessoal e ativo de interpretar a si mesmo e ao outro.

O self com seus elementos constituintes não é uma consciência e vontade independentes dos contextos socioculturais (Richardson, Rogers, \& McCarrol, 1998). Ele só pode ser compreendido mediante seu caráter situado, por isso temporal. É a ênfase no caráter dialógico e comunicacional do self que nos leva a considerar a diversidade dos contextos de vivência do sujeito (Macedo \& Silveira, 2012). O self como uma narrativa espacialmente estruturada e corporificada existe em diálogo com as práticas discursivas.

Como construção relacional, dialógica, social e temporal, o sistema de self deve ser compreendido mediante as trajetórias pessoais, sem desconsiderar trajetórias coletivas, historicamente situadas. Nesse sentido, na compreensão das trajetórias, as narrativas são formas de as pessoas elaborarem significados e darem sentido às experiências vividas e imaginadas, dentro de limites e possibilidades socialmente negociados. A pessoa constrói trajetórias de desenvolvimento na relação de aproximação e distanciamento entre história coletiva, experiências vividas e perspectivas futuras e, nesse processo, orienta seu modo de ser e sentir no mundo. Ela constrói e reconstrói enredos de si, utiliza e transforma a própria trajetória mediante interações no presente, ressignificações do passado e futuros imaginados. Conserva um sentido de si com base em uma organização repetida das relações enfatizadas nas suas trajetórias de vida (Davies \& Harré, 1990). 
O self é polifônico, isto é, constitui-se no diálogo com versões internalizadas das relações nas quais participa (Fogel et al., 2002). Contudo, sempre tem uma audiência. A experiência subjetiva se dá em um contexto e com um público específicos, para os quais constantemente constrói narrativas de si.

Experienciar-se e narrar a própria história são processos canalizados pelas linguagens sociais. Da mesma forma, os diálogos, reais ou imaginados, acontecem dentro de uma estrutura socialmente construída. Estruturas são como padrões estáveis de atividades mutuamente coordenadas e relacionadas ao tema, à definição e ao alcance do diálogo. E as recorrências de padrões de relacionamento ao longo do tempo, apesar de sugerirem uma ideia de regularidade e estabilidade, são diferentes e inovadoras, resultado do diálogo constante entre sujeito e cultura.

Assim, o self, que tende simultaneamente à estabilidade e à mudança, resulta das constantes negociações entre elementos internos, que o habitam, e elementos externos, orientados por instituições sociais que coordenam e monitoram interações. O desenvolvimento do sistema de self é dialógico e marcado pela relação entre cognição, afeto e ação (Valsiner, 2007), onde a mudança se origina de inovações criativas a partir de diálogos intrapessoais e interpessoais (Fogel et al., Bell, 2002).

\subsection{Uma orientação afetiva no desenvolvimento do sistema de self}

A dimensão subjetiva do ser humano é a dimensão do afeto e dos sentimentos (Valsiner, 2012). E a psicologia cultural, ao se interessar pelo estudo científico dos processos de significação, focaliza transições de desenvolvimento que se caracterizam pela unidade entre afeto, linguagem e cognição. Esses processos são coconstruídos e estão em constante transformação durante toda a trajetória de vida do sujeito.

Segundo Valsiner (2012), os sentimentos são fenômenos intrapsicológicos e, portanto, não podem ser reduzidos a emoções, que são expressões intersubjetivas dos sentimentos. Os sentimentos só são revelados mediante a ação do sujeito. Como pesquisadores, interpretamos sentimentos dos nossos participantes de pesquisa mediante ações comunicativas e metacomunicativas. Por sua vez, as emoções são categorias expressas dentro de limites e possibilidades da comunicação humana. Nosso modo de sentir é muito mais complexo do que nossos esforços de descrição e explicação, delimitados por um aparato linguístico, podem alcançar. E os significados emergem desse complexo modo de sentir, orientado por elementos culturais e históricos. Assim, as emoções são 
padrões que emergem através da comunicação, e não como processos internos do indivíduo que se exteriorizam subsequentemente. [...] São vivenciadas e emergem como parte de atividades corporais entre indivíduos que coexistem e se corregulam com o outro, ao longo do tempo, em contextos comunicativos. (Garvey, 2014, p. 21)

A dimensão afetiva da pessoa humana se organiza em níveis que podem ir desde processos fisiológicos imediatos até processos de grande complexidade, derivados de mediações simbólicas, denominados campos afetivos semióticos hipergeneralizados (Valsiner, 2012). Os signos hipergeneralizados são parte de um sistema de categorização das produções semióticas caracterizado por níveis que se relacionam de modo dinâmico: nível 0 (fisiológico: excitação e inibição); nível 1 (pré-verbal), definido como um estado antecipatório, quando não é solicitada a mediação semiótica; nível 2, no qual a pessoa nomeia as próprias emoções, dizendo, por exemplo, estar feliz, angustiada, preocupada (ocorrendo assim uma racionalização das emoções); nível 3, quando as emoções categorizadas no nível 2, considerando seu uso contínuo pelo sujeito, são generalizadas para modos de sentir mais abrangentes, como "me sinto mal, me sinto bem"; e nível 4, em que o sujeito tem dificuldades para expressar, em palavras, os sentimentos que ancoram sentidos e significados nesses campos semióticos hipergeneralizados. Eles possuem forte influência sobre os outros elementos do sistema, que estão em níveis mais baixos de generalização. Assim, os signos que povoam os campos afetivos semióticos hipergeneralizados possuem importante papel nos processos de desenvolvimento, ao longo da trajetória de vida do sujeito. Isso porque, sendo carregados de afeto, são mais resistentes a mudanças.

Nesse sentido, estudos desenvolvidos pela psicologia ainda apresentam expressiva dificuldade em tratar fenômenos afetivos hipergeneralizados, como os valores (Valsiner, Branco \& Melo, 1997), que tomam centralidade no presente estudo. Como fenômenos humanos, eles são recursos semióticos de orientação afetiva internalizados e reforçados na trajetória de vida do sujeito, mediante a participação da pessoa em diferentes contextos. Ao tentarmos conceituar os valores, acabamos por categorizá-los. E precisamos ter clareza de que isso ocorre dentro de limites e possibilidades dos processos comunicativos simbólicos disponíveis numa determinada cultura. Os valores não são entidades; devem ser considerados como campos semióticos em movimento, dificilmente acessíveis mediante processos verbais. São campos afetivos semióticos hipergeneralizados.

Como campos semióticos nebulosos, os valores medeiam semioticamente o afeto. O modo de o sujeito sentir-se no mundo, afetar e ser afetado por ele, passa a ser mediado por seus valores, coconstruídos nas interações sociais. "Uma vez que se torna hipergeneralizado, o signo tipo campo, de caráter afetivo, começa a colorir cada nova experiência" (Valsiner, 2012, p. 262). Logo, o afeto está na base das significações e ressignificações das experiências vividas, bem como das expectativas e dos futuros imaginados. Como campos hipergeneralizados, eles impõem sentimentos 
que orientam a construção do sistema de self e os modos de a pessoa sentir-se no mundo vivido e imaginado.

O afeto, como elemento constituinte desse sistema, é um processo histórico, ontogenético e filogenético que coemerge através da comunicação e com ela se desenvolve. Como processo histórico, possui um passado, mas também influencia possibilidades e futuros imaginados (Lyra, 2000). Por tudo isso, atua no fluxo complexo da comunicação. Abre, coordena e/ou fecha possibilidades de relacionamento inter e intrapsicológico. Nesse sentido, uma abordagem da dimensão afetiva do ser humano, coerente com a complexidade do desenvolvimento da pessoa, deve ser sistêmica, relacional e histórica (Forgel \& Garvey, 2007; Lyra, 2006). 


\section{JUVENTUDE: UMA EXPERIÊNCIA SUBJETIVA CANALIZADA SOCIALMENTE}

Fundamentado nos pressupostos da psicologia cultural e na compreensão dialógica do desenvolvimento do sistema de self, o presente capítulo discute o tema da juventude como objeto da psicologia. A noção de desenvolvimento humano como fenômeno eminentemente cultural e relacional é a base para este estudo da construção do dinâmico sistema de self de jovens em formação para a vida religiosa consagrada. Assim, compreender a complexidade do fenômeno juventude - uma experiência subjetiva, ainda que canalizada socialmente - e das trajetórias de desenvolvimento que nele se processam exige considerar as perspectivas e significações que os jovens constroem acerca de si, em diálogo com limites e possibilidades socioinstitucionais.

Como fenômeno psicossocial e histórico, a juventude compreende o período, maior ou menor, conforme os contextos histórico-culturais, de transição entre a adolescência e a vida adulta. Nesse período, transformações em diferentes ordens, como a cognitiva, a política, a sexual e a de cidadania (Levi \& Schmitt, 1996), orientam e são orientadas por movimentos semióticos na autoimagem do jovem, bem como pela maneira como esses sujeitos são vistos e enquadrados em meio a um sistema de valores e crenças sociais (Dayrell, 2007; Gomes, 2010; Leão, Dayrell, \& Reis, 2011; Santos \& Bastos, 2012; Zittoun, 2006b). Assim, um ponto de partida para compreender transições juvenis "passa por reconhecer as representações que são produzidas sobre os jovens" e pelos jovens (Dayrell \& Carrano, 2014, p. 105).

Conquistas como maior autonomia e mobilidade social, inserção em novos grupos, experiências amorosas, novas responsabilidades na família e na comunidade, e ingresso no mundo do trabalho formal são exemplos de reposicionamentos sociais que possibilitam (ou exigem) reconfigurações no sistema de self do jovem. De maneira dinâmica, ajustes entre modos de ser e de sentir e expectativas socioinstitucionais contribuem na ressignificação das relações do jovem consigo mesmo e com o mundo. E as culturas sugerem relevância e significados a esses fatores de modos distintos, caracterizando as trajetórias juvenis mediante um determinado recorte de práticas sociais.

Considerar as mudanças que, de modo complexo e dinâmico, ocorrem nas transições juvenis é reconhecer a potencialidade desses processos na transformação do sistema de self na trajetória de vida do sujeito. Isso contribui para a compreensão de processos gerais e generalizáveis, bem como processos típicos de determinado momento da vida, no diálogo entre aspectos psicológicos e sociológicos. Apesar de pesquisadores se interessarem cada vez mais pelo estudo da juventude em diversas áreas, a configuração dinâmica dos sentidos subjetivos, responsáveis pela orientação de posicionamentos, escolhas e perspectivas, ainda precisa ser mais 
bem estudada e compreendida pela ciência psicológica quando se refere a esse momento do desenvolvimento (Zittoun, 2007a).

A sociologia tem contribuído de modo significativo para a compreensão da juventude, sobretudo destacando aspectos macrossociais e mensurando estados e resultados relacionados a papéis sociais e estágios alcançados pelo indivíduo dentro de estruturas tradicionalmente valorizadas (Camarano, Mello, \& Kanso, 2006; Dayrell, Carrano \& Maia, 2014; Elder \& Shanahan, 2006; Furstenberg, Rumbaut, \& Settersten, 2005; Mortimer, 2003). Contudo, esses estudos focam uma compreensão da juventude mais a partir de suas trajetórias sociais e menos das transições de desenvolvimento vividas no plano subjetivo (Mattos, 2013).

Neste estudo, nosso foco recai sobre as transições de desenvolvimento juvenil, em diálogo com esferas de experiência, especialmente a transição em direção ao ser religioso consagrado. A investigação discute transformações no sistema de self da pessoa em diálogo não só com experiências e contextos vivenciados, mas também com expectativas e futuros imaginados. Desse modo, as trajetórias são vistas como o resultado atualizado das várias transformações pelas quais o indivíduo passa ao longo da vida; e as transições de desenvolvimento correspondem a momentos específicos, marcados por mudanças simultâneas que exigem do sujeito um reposicionamento psicossocial e o assumir de novos papéis e responsabilidades (León, 2009; Mattos, 2013).

Estudos de psicologia, sociologia e ciências da religião também têm ressaltado a juventude como condição de desenvolvimento (Abramo, 2005; Araújo \& Lopes de Oliveira, 2010, 2013; Dayrell, 2007; Lopes de Oliveira, 2006; Ozella, 2003; Paiva, Bezerra, Silva, \& Nascimento, 2013; Souza \& Paiva, 2012; Sposito, 2005; Takeuti, 2012). Essas pesquisas destacam novos modos e espaços de socialização utilizados pelos jovens que, muitas vezes, influem no desenvolvimento desses sujeitos, tanto ou mais que as instituições tradicionais, como a escola e a família (Abad, 2003; Sposito, 2005). Tal reconhecimento é fundamental na compreensão das condições de trajetória juvenil nas sociedades contemporâneas.

Como processos negociados dialogicamente, as transições juvenis se constituem na dinâmica de internalização e externalização ativa de experiências em diferentes contextos socioculturais e se expressam nas práticas narrativas e comportamentais. A narrativa, como prática social e atividade autoepistêmica (Wortham, 2000), é estruturada em uma linguagem socialmente partilhada. Da mesma forma, é orientada por uma audiência e externaliza sistemas pessoais de significação, com crenças, valores e expectativas coordenadas nas interações intra e interpessoais.

Os sentidos de si dos jovens, seus processos identitários, são permeados pelas narrativas produzidas socialmente por eles e sobre eles. São histórias intersubjetivamente negociadas a partir de organizações e reorganizações dos sistemas semióticos (Bruner, 2004). As constantes tensões entre continuidade e mudança marcam a trajetória de desenvolvimento da pessoa. E as 
possibilidades e os limites de ser jovem numa determinada esfera de experiência canalizam esses processos de tensão, resultantes de ajustes entre pessoal e cultural.

Por sua vez, a vivência religiosa do jovem como contexto de desenvolvimento define pautas específicas. As narrativas pessoais acerca da experiência religiosa são processos de (re)significação de si, relevantes para a investigação do sistema de self. E a experiência vocacional religiosa, vista aqui como um espaço semiótico de desenvolvimento, é atravessada por narrativas institucionais, bem como por momentos de continuidade e descontinuidade que participam na constituição do eu. No que tange à religiosidade como contexto experiencial de desenvolvimento, tema discutido a seguir, esses processos ainda são pouco estudados entre os jovens (Godinho, 2007; Paiva, 1998; Martins \& Carvalho, 2013; Novaes, 2004), especialmente do ponto de vista da psicologia

cultural. 


\section{A EXPERIÊNCIA VOCACIONAL RELIGIOSA COMO CONTEXTO DE DESENVOLVIMENTO}

A palavra "contexto" (do latim contextus) significa reunião, conjunto, sucessão. E a palavra "texto" significa tecido. Portanto, o contexto nos remete ao ato de tecer e entrelaçar. Ele pode representar um ambiente físico ou situacional, cujo conhecimento se faz necessário na compreensão da mensagem transmitida pelo locutor (autor, emissor) ao interlocutor (leitor, receptor).

Malinowski (1884-1942) foi quem ampliou o uso da palavra "contexto" para representar não apenas a situação discursiva imediata, mas o ambiente cultural a partir do qual se considera um fato ou fenômeno (Halliday \& Hasan, 1989). Para Malinowski, essa ampliação do conceito de contexto era fundamental para compreender um texto. Em psicologia cultural, por sua vez, o contexto ajuda a reiterar a unidade pessoa-ambiente na abordagem dos fenômenos psicológicos, assim como o caráter semioticamente mediado dessa relação. Em outras palavras, o que constitui um segmento de realidade em contexto é a relação de sentido entre o sujeito e tal realidade, por meio da ação ou experiência humana. Assim, estudar o contexto de desenvolvimento de um fenômeno humano é considerar objetos, narrativas, limites e possibilidades físicas e simbólicas em meio às quais acontecem as interações organismo-cultura.

O contexto é palco de construções e transformações dos fenômenos sociais e humanos, o que faz dele uma dimensão constitutiva e indispensável na compreensão da gênese e história de um fenômeno. Como constituintes das relações, os contextos são históricos, dinâmicos e estão sempre em transformação na linha do tempo. A dimensão temporal, como parte do conjunto de circunstâncias de uma realidade, garante a historicidade do contexto. Os fatos acontecem num ambiente físico ou situacional, na intersecção entre tempo e espaço. E os fenômenos não são neutros; trazem novas configurações aos contextos pelos quais são canalizados. Logo, ao analisarmos o contexto de um fenômeno devemos considerar, além de suas características - que podem ser materiais e simbólicas —, as várias possibilidades de relações entre o fato ou fenômeno avaliado e as características externas do meio em que o fenômeno ocorre, incluindo a dimensão temporal.

Em se tratando dos fenômenos humanos, o contexto envolve elementos externos e sentidos subjetivos: crenças, valores, habilidades pessoais, experiências vividas e ressignificadas no presente, expectativas e futuros imaginados, por exemplo. Portanto, o contexto existe para o sujeito, sendo experimentado e vivido de modo singular pela própria pessoa. O presente estudo considera, em especial, a experiência vocacional religiosa como importante elemento do contexto de desenvolvimento dos participantes. Parte da premissa de que, como toda experiência vivida, o 
sentir-se vocacionado(a) à vida religiosa consagrada direciona escolhas, orienta significados e ressignificados das experiências vividas e imaginadas. Portanto, ao integrar o contexto sociocultural da pessoa, potencializa, de modo peculiar, processos de subjetivação e identidade.

Segundo Camboim e Rique (2010), "religiosidade é definida como a extensão na qual um indivíduo acredita, segue e pratica uma religião" (p. 252). Esses autores concordam que a religiosidade pode ser compreendida como uma dimensão ampla, podendo independer de denominações institucionalizadas da religião. Para Pinto (2009), "originária da religião, a religiosidade pode ser entendida como uma experiência pessoal e única da religião, ou seja, 'a face subjetiva da religião"” (p. 74). E Brandão (2004) defende que a "realização cotidianamente humana e espiritual de cada pessoa, grupo ou comunidade cultural, está na vivência íntegra de sua própria e dialógica experiência do sagrado" (p. 277).

Diversos estudiosos nas áreas da saúde, teologia, psicologia, educação e filosofia têm explorado a interface entre o sagrado e o humano (Brannon \& Feist, 2001; Calvetti, Muller \& Nunes, 2008; Fabrega, 2000; Faria \& Seidl, 2005; Fernandes, 2015; Fleck, Borges, Bolognesi, \& Rocha, 2003; Paiva, 2004, 2007; Peres, Simão \& Nasello, 2007; Stroppa \& Moreira-Almeida, 2008). De modo geral, esses trabalhos destacam a importância do estudo da religiosidade para uma compreensão holística do ser humano (Calvetti et al., 2008).

$\mathrm{Na}$ presente investigação, consideramos a religiosidade como vivência e construção pessoal, canalizada pelos limites e pelas possibilidades da experiência social. Portanto, analisamos a experiência religiosa como processo constituído mediante símbolos, significados e sentidos subjetivos, disponíveis nas relações e instituições socioculturais. De acordo com Dalgalarrondo (2008), essa experiência pode ser ressignificada ao longo da trajetória de vida da pessoa. Crianças, jovens e adultos experimentam a religiosidade de modos diferenciados e assim constroem uma identidade que, todavia, não se traduz espontaneamente em vocação religiosa. A vocação para a vida religiosa consagrada é uma das muitas trajetórias possíveis na vivência da religiosidade cotidiana.

A palavra "vocação" deriva do verbo vocare, em latim, que significa "chamar" e tem como raiz a palavra vox. O termo é sempre compreendido na voz passiva, isto é, "ser chamado(a)". Segundo Noé (2010), “onde se fala em vocação, entende-se 'ser vocacionado', ou seja, em uma formulação livre, ouvir a voz que chama" (p. 169). Na perspectiva cristã, há diferentes chamados para diferentes vocações. O cristianismo entende que o ser humano, como filho de Deus e seguidor de Jesus Cristo, é chamado a colaborar na construção de um mundo onde todos vivam como irmãos (Noé, 2010). Assim, o chamado para a vocação, segundo os fundamentos teológicos da Igreja Católica, deve ser respondido por todo e qualquer cristão, seja como leigo, como religioso consagrado (leigo consagrado) ou como clérigo (padre). Os padres e religiosos consagrados são membros de uma instituição, seguem estatutos e regras definidas pelas congregações religiosas de 
que fazem parte, que são aprovadas pela Igreja Católica. Os leigos, por sua vez, são orientados a viver sua vocação nos vários segmentos da sociedade, seja como pais de família, seja no exercício profissional, sempre considerando os ensinamentos evangélicos.

A palavra portuguesa "religião" é derivada da palavra latina religionem (religio no nominativo) e, na tradução alemã de Martinho Lutero (1483-1546), é Gottesdienst, que pode ser traduzida para "serviço a Deus" (Filoramo \& Prandi, 1999). No mundo latino anterior ao surgimento do cristianismo, a palavra religionem era usada para se referir a um comportamento marcado pelo rigor e pela precisão. Como um conjunto de sistemas culturais, crenças e visões de mundo, a religião sugere símbolos e significados que podem coordenar modos de ser e de sentir da pessoa nas esferas de experiência. Assim, figuras religiosas, como os santos e o próprio Deus, são alteridades que ajudam a construir posicionamentos no sistema de self.

Vários estudos discutem interfaces entre religião ou experiência religiosa e psicologia. Grande parte deles não pretende representar um estudo da religião a partir da psicologia, mas sim um diálogo entre psicologia e religião (Amatuzzi, 1997, 2005; Ávila, 2003; Baptista, 2004; Dalgalarrondo, 2006; Henning \& Moré, 2009; Jung, 1978; Lukas, 2002; Paiva, 1998). Apesar de considerado difícil, esse diálogo tem encontrado seu ponto de convergência na busca de compreensão do sentido do ser humano, tarefa a que ambos os campos se dedicam.

Visto que a religião constitui, sem dúvida alguma, uma das expressões mais antigas e universais da alma humana, subtende-se que todo o tipo de psicologia que se ocupa da estrutura psicológica da personalidade humana deve pelo menos constatar que a religião, além de ser um fenômeno sociológico ou histórico, é também um assunto importante para grande número de indivíduos. (Jung, 1978, p. 6)

Segundo Paiva (1998), já em 1903, em um dos primeiros congressos de psicologia, o psiquiatra Théodore Flournoy (1854-1920) defendeu, sob muita resistência, que um estudo psicológico da religião deveria focar o comportamento das pessoas religiosas e não o objeto desse comportamento. Nesse sentido, a experiência religiosa é discutida como potencialmente capaz de transformar a vida da pessoa, abrindo-se "para um mundo inteiramente novo e diferente do cotidiano, do qual só é possível dar conta a partir de dentro dele mesmo" (Amatuzzi, 1997, p. 37).

A experiência religiosa é resultado da relação dialógica entre a pessoa e o sagrado. Por sua vez, o sagrado é inerente ao fenômeno religioso. Assim, identificar e compreender onde esses dois fenômenos se tocam é tarefa complexa e sutil. Segundo Pereira (2007), ao falarmos de experiência religiosa, precisamos considerar os olhares de diferentes escolas de pensamento que definem esse fenômeno, sempre dentro de um espaço e tempo específicos. O olhar teológico sobre a experiência religiosa na contemporaneidade se diferencia, por exemplo, do pensamento dos teólogos do século XVIII. Naquela ocasião, o pensamento religioso estava marcado pelo empirismo, tendo o termo "experiência" a conotação de contato percepto-cognitivo, objetivamente apreensível, com um 
fenômeno. Nos dias atuais, segundo Figueira (2007), a ideia de experiência religiosa caracteriza-se primordialmente por uma vivência que considera a consciência de um mundo sobrenatural, bem como a existência e o conhecimento de práticas que regem as relações entre o homem e o sagrado.

Paiva (1998) também já havia defendido a importância de considerar o contexto histórico e as associações do termo "experiência" com a questão religiosa. Ele ressalta que essa associação teve início na modernidade, com as discussões de F. Schleiermacher (1768-1834), sendo divulgada a partir das ponderações de W. James (1842-1910) e consolidada epistemologicamente com R. Ouo (1869-1937). O mesmo autor ressalta a necessidade de discutir a experiência de um lugar exclusivamente religioso, enfatizando que é a própria pessoa, grupo ou cultura que pronunciam a experiência religiosa, e não as ciências, quer a psicologia, a sociologia ou a antropologia (Paiva, 1993, 1998). Portanto, é preciso "partir de um conhecimento meta empírico para se falar, com sentido, do transcendente" (1998, p. 155).

Ao discutir o conceito de experiência religiosa, Valle (1998) recorre à palavra alemã Erlebins, que significa experiência. A palavra traz o sentido emocional e é usada sempre que se quer referir a uma experiência profunda, a algo vivenciado de dentro e dotado de um sentido ou valor para o indivíduo. Segundo o autor, a vivência subjetiva deve estar em primeiro plano na discussão da experiência religiosa.

Em um estudo sobre a fenomenologia da experiência religiosa, Pereira (2007) defende que o ser humano é “intrínseca e essencialmente experiência. Faz-se experimentando-se e experienciando o diverso dos possíveis de que dispõe como possíveis. [...] A experiência é exclusivamente humana" (p. 11). O autor ressalta esta como uma condição ontológica do humano, independente de verdades "de tipologia não natural ou religiosa", e assim "a experiência dita religiosa, a existir, é exclusivo próprio do homem e de mais nenhum outro ser" (Pereira, 2007, p. 11).

O presente estudo não tem a pretensão de discutir o conceito, a profundidade, nem tampouco a materialidade ou não da experiência religiosa. O objetivo aqui é buscar caminhos possíveis na compreensão dessa experiência como signo regulador de complexos semióticos presentes no sistema de self - um campo simbólico e peculiar de ação para o sujeito (Valsiner, 2002), promotor de processos de desenvolvimento na configuração de uma posição de self vocacional.

O sujeito se faz na relação com os contextos socioculturais, ao longo do curso de vida. E as histórias que conta são, simultaneamente, uma prática social e uma atividade autoepistêmica. A narrativa é canalizada por uma linguagem que estrutura o ato de tornar pública uma experiência privada, marcada por crenças e valores (Lacasa, Del Castillo \& García-Varela, 2005; Lopes de Oliveira, 2006). Assim, ela se constitui como um contexto microgenético em que os sujeitos se 
apresentam publicamente, considerando uma relação de tensão entre os ambientes socioinstitucionais e a noção de si negociada intersubjetivamente.

Neste trabalho, a experiência vocacional religiosa dos participantes é tomada como parte constituinte e constitutiva da história pessoal do sujeito, num contexto sociocultural. A experiência vocacional religiosa, assim entendida, é parte do mundo e do ser que a vive, externalizada mediante gestos, posicionamentos e narrativas. Trata-se de uma experiência que pode ser conhecida de forma mediada por signos socialmente construídos e partilhados. Daí, o sentido da experiência vocacional religiosa é mesmo o sentido haurido dessa experiência: é no cotidiano que a pessoa vivencia as vicissitudes e peripécias de suas experiências (Fernandes, 2015). 


\section{OBJETIVOS}

\section{Objetivo Geral}

Investigar, numa perspectiva semiótico-cultural, transições de desenvolvimento e sistema dialógico do self à luz da experiência de jovens em formação para a vida religiosa consagrada.

\section{Objetivos Específicos}

- Investigar, mediante quatro estudos de caso, a emergência, o desenvolvimento e a manutenção do sentir-se vocacionado à vida religiosa consagrada;

- Interpretar complexos semióticos orientadores de transições de desenvolvimento na construção de um "Eu religioso consagrado";

- Discutir o papel constituinte e regulador de signos da tradição católica na canalização de sentidos na experiência religiosa; 


\section{METODOLOGIA}

A metodologia é um processo construído ao longo do trabalho investigativo. Como ferramenta para auxiliar a investigação e solução de problemas de pesquisa, esse processo cíclico e dinâmico se define em torno de um conjunto de fatores, entre os quais se encontram a visão de mundo do pesquisador e sua postura interpretante; os referenciais teóricos adotados; o fenômeno investigado; e a relação dialética entre os métodos de pesquisa e as informações construídas. Tudo isso faz da pesquisa um processo de construção contínua, ao mesmo tempo empírica e teórica (Branco \& Valsiner, 1997; Madureira \& Branco, 2001).

O presente estudo adota uma perspectiva qualitativa. A pesquisa qualitativa contrapõe a visão de ciência como um método a ser seguido, como um conjunto de regras que visa ao total controle do processo, tornando possível replicá-lo, criticá-lo e, eventualmente, refutá-lo. Nesse tipo de pesquisa, o conhecimento é produzido a partir das informações e dos significados negociados em um processo coletivo e individual, ativo, cognitivo e afetivo, situado num tempo irreversível e, desde sempre, canalizado por contextos socioculturais. As realidades sociais e subjetivas são consideradas numa relação dialógica e constitutiva, em meio a suas complexidades e dinamismos.

Adotar uma perspectiva qualitativa no estudo do desenvolvimento humano coloca-se como um desafio, dada a complexidade da existência humana. Lidamos com um objeto de pesquisa complexo e resistente a qualquer tipo de previsão e normatização: “o homem não é uma magnitude final e definida, que possa servir de base à construção de qualquer cálculo; o homem é livre e por isto pode violar quaisquer leis que lhe são impostas" (Bakhtin, 2008, p. 67). Também é desafiante, e requer uma postura ética, o fato de a investigação do desenvolvimento ser guiada e interpretada por um outro sujeito, o pesquisador, com suas crenças e seus valores, sua história e seus posicionamentos epistemológicos.

Valsiner (2000, 2002), Branco e Valsiner (1997), Lopes de Oliveira (2006, 2016) e González Rey (1998, 1999) são estudiosos que vêm destacando a imersão do pesquisador no contexto da pesquisa e o caráter interpretativo do conhecimento, características marcantes na pesquisa qualitativa. Em uma epistemologia qualitativa, a metodologia deixa de ser apenas o caminho pelo qual se deve seguir na busca do conhecimento e passa a ser vista como processo cíclico e dinâmico de construção de conhecimentos (Branco \& Rocha, 1998) - o que contraria a ideia de que os dados são capazes de falar por si mesmos (Branco \& Valsiner, 1997; Valsiner, 1989). Nesse sentido, o mais importante não é a quantificação e a busca de verdades únicas, possíveis de generalizações. O foco é um conhecimento produzido na pesquisa apoiada numa perspectiva sócio-histórico-cultural, configurado na interação comunicativa entre investigador, fenômeno investigado e contextos sócio-históricos e culturais. 
Diante desses pressupostos metodológicos, ficam inconcebíveis, no processo de construção de qualquer pesquisa qualitativa, a desvinculação e a dissociação entre produção empírica e produção teórica (Branco \& Rocha, 1998; Branco \& Valsiner, 1997; González Rey, 1998, 1999; Valsiner, 1989). Por isso, as informações construídas (não coletadas) no contexto da pesquisa não são divorciadas dele; pelo contrário, elas só existem em referência a tal contexto (Araújo \& Lopes de Oliveira, 2010).

Nesta pesquisa, será reservado lugar de destaque aos sujeitos pesquisados, priorizando processos e valorizando tanto o contexto quanto as interações nele ocorridas. Por tudo isso, a epistemologia e a metodologia qualitativas emergem como mais adequadas ao estudo de transições juvenis e da constituição do sistema de self, visto que consideram aspectos sociais, históricos e culturais. A pesquisa qualitativa tem como pressuposto uma noção de sujeito que deve ser considerada durante todo o processo metodológico do estudo, sob o risco de chegar a análises das informações que se mostram desconectadas do referencial teórico-metodológico.

Segundo Flick (2004), ao falarmos em pesquisa qualitativa, devemos ter a consciência de que estamos nos referindo a várias abordagens que diferem umas das outras em questões teóricas e metodológicas. Para esse autor, há abordagens que destacam o ponto de vista do sujeito, assim como há aquelas que se dedicam a descrições de contextos ou se interessam pela ordem social e sua criação. Contudo, "cada uma dessas posturas conceitua, de diferentes formas, o modo como os sujeitos em estudo - suas experiências, ações e interações - relacionam-se ao contexto no qual são estudados" (p. 33).

A pesquisa qualitativa é um processo de interpretação e compreensão para além da explicação das realidades. "A realidade estudada pela pesquisa qualitativa não é uma realidade determinada, mas é construída por diferentes 'atores"” (Flick, 2004, p. 43), incluindo o próprio pesquisador. Dessa forma, como construção dinâmica e complexa, a realidade social não pode ser apreendida, de uma vez por todas, como coisa pelo sujeito, mas deve ser interpretada e compreendida em um processo histórico, sistêmico e contextualizado, em que partilhamos e construímos significados.

A realidade não é a coisa, não está na cabeça, mas no ato de discutir e negociar sobre o significado de tais conceitos. As realidades sociais não são tijolos nos quais tropeçamos ou nos contundimos quando os chutamos, mas os significados que conquistamos ao partilhar cognições humanas. (Bruner, 2002, p. 128)

Esse caráter construtivo, relacional e dinâmico da realidade social, o destaque ao caráter processual e reflexivo do saber e a importância da realidade objetiva nos significados subjetivos são fundamentos teóricos da pesquisa qualitativa (Flick, Von Kardorff, \& Steinke, 2000). Mediante variadas práticas interpretativas, a pesquisa qualitativa é marcada pela busca, como princípio do conhecimento, de uma compreensão das complexas relações constituintes da realidade social. É 
uma abordagem que parte da ideia de realidade como construção dos sujeitos, mediante suas narrativas e seus textos. A pesquisa qualitativa "consiste em um conjunto de práticas materiais e interpretativas que dão visibilidade ao mundo" (Denzin \& Lincoln, 2006, p. 17).

Nessa perspectiva, o pesquisador é parte da realidade investigada. Suas escolhas, seus posicionamentos e tudo que o constitui estão em diálogo com o contexto de pesquisa e devem ser considerados no momento de análise das informações. Numa relação dialógica e colaborativa, em interação com os contextos socioculturais, incluindo futuros imaginados, pesquisador e participantes da pesquisa estão em constante transformação. Como um observador localizado no mundo, o pesquisador busca interpretar e compreender seu objeto de pesquisa, considerando o contexto, bem como os significados que os atores desse cenário explicitam (Bolívar, 2001; González Rey, 2002; Günther, 2006). Para tal compreensão, quando possível, é importante uma variedade de práticas interpretativas, visto que a diversidade dessas práticas pode revelar diferentes facetas do objeto em estudo, possibilitando uma compreensão mais aprofundada do fenômeno (Denzin \& Lincoln, 2006).

A ideia de um sujeito que se configura no diálogo consigo mesmo e com o outro valoriza aspectos biológicos e sociais, que se imbricam no tempo e espaço. Segundo Bruner (2002), está aí a principal premissa que fundamentou o pensamento de Vygotsky: "a visão de que o homem estava sujeito ao jogo dialético entre a natureza e a história, entre suas qualidades como criatura da biologia e como um produto da cultura humana" (p. 76). Nesse sentido, as ciências humanas, especialmente a psicologia, têm como desafio compreender o sujeito em sua totalidade, como uma unidade corpo e mente, que cria significados e a própria consciência, imerso em uma cultura produzida e reproduzida por ele, que igualmente o produz e reproduz (Freitas, 1996).

O sujeito da pesquisa qualitativa (pesquisador ou participante pesquisado) é um sujeito que produz signos, se expressa, fala, compreende, se comunica. Como um sujeito de voz, é na relação dialógica que ele se revela, que se deixa conhecer ao mesmo tempo que toma consciência de si. É, ainda, pelo diálogo que ele se constitui e participa da constituição do outro (Bolívar, 2001; Connelly \& Clandinin, 1990; Freitas, 2002). Dessa forma, o ponto de vista do sujeito deve ser colocado em evidência (Flick, 2004), por meio de sua convocação a narrar a própria história. Narrando sua história ele se faz, se constitui: "não fazemos a narrativa de nossa vida porque temos uma história; temos uma história porque fazemos a narrativa de nossa vida" (Delory-Momberger, 2008, p. 37). Ao se expressar, o sujeito se coloca em relação consigo mesmo, com o outro e com o contexto.

A perspectiva dialógica defende a possibilidade da compreensão do sujeito, da sua história e sua vida cotidiana mediante os textos que esse sujeito cria e recria como signos compartilhados. "A própria consciência só pode surgir e se afirmar como realidade mediante a encarnação material em signos" (Bakhtin, 1988, p. 33). Na perspectiva dialógica pensamos, construímos e 
transformamos pensamentos ao interagirmos com o pensamento dos outros. Assim, nossa voz é carregada de outras vozes, de vozes alheias, de experiências que, mesmo sendo nossas, só existem e têm sentido relacionadas ao outro (Bakhtin, 1997).

A subjetividade presente nas práticas de pesquisa qualitativa torna-se um aspecto especialmente relevante para os estudos no campo do desenvolvimento humano. Isso porque a pesquisa não apenas retrata processos de desenvolvimento, mas, muitas vezes, promove dinâmicas de desenvolvimento, por exemplo, no contexto de entrevistas e de grupos focais. Ao produzir conhecimento a partir de uma pesquisa, assume-se "a perspectiva da aprendizagem como processo social compartilhado e gerador de desenvolvimento" (Freitas, 2002, p. 25).

O momento de entrevista, nesse sentido, é um espaço de interpretação do passado vivido e do futuro imaginado. Recontar a própria trajetória de vida é uma oportunidade de fazer releituras e ressignificações de si. Logo, numa situação de entrevista, só é possível compreender o sujeito que é, a pessoa no presente fronteiriço entre um passado (re)significado e um futuro imaginado. Investigar a vida pregressa e o futuro imaginado da pessoa é investigar como o sujeito atribui significado à própria história, na linha do tempo, em diálogo com contextos socioculturais, fazendo sentido de si num tempo irreversível.

É importante ter claro que o resultado de uma pesquisa científica é sempre uma compreensão (entre outras possíveis) de um momento da realidade coconstruída. E essa compreensão é atravessada pelo contexto histórico-cultural, em um tempo e espaço, e pelas subjetividades que são constituídas e constituintes das relações dos sujeitos envolvidos.

O tema da subjetividade na pesquisa é central no tipo de investigação aqui proposto. Merleau-Ponty (1991), no livro Os signos, ressalta que os estudiosos da subjetividade não fizeram descobertas, mas construções, destacando uma ontologia não substancial da subjetividade. "A subjetividade não estava esperando os filósofos como a América desconhecida estava esperando nas brumas do oceano os seus exploradores. Eles a construíram, a fizeram, e de mais de uma maneira” (p. 168). Compreendida como construção, a subjetividade se coloca na esfera dos fenômenos. É organizada de modo sistêmico e complexo, ou seja, configura-se em uma tensão própria dos sistemas complexos, rompendo-se com ideias deterministas e mecanicistas. Assim, a subjetividade deve ser vista não de modo fragmentado, mas nas suas várias dimensões constituintes.

O objeto de estudo das ciências humanas exige uma atenção aos seus aspectos políticos, sociais, históricos, econômicos, psicológicos e biológicos. Demanda também um caminho de investigação que considere processos, particularidades, subjetividades, liberdade de escolha, relações dialógicas. A legitimidade da pesquisa nesse campo está afinada com um suporte teórico que fundamenta as opções metodológicas e com discussões que consideram o caráter, dinâmico, processual e contextualizado do conhecimento. Tais posicionamentos nos ajudam a fugir de um 
subjetivismo, onde tudo seria explicado pelo sujeito pesquisador, sem uma discussão crítica que chame para o diálogo teorias e metodologias capazes de problematizar o objeto de pesquisa.

Segundo Flick (2004), na pesquisa qualitativa, a confiabilidade ganha importância como critério de avaliação quando é colocada em tensão com uma teoria que problematiza o assunto em estudo e que aborda o uso de métodos. Esse mesmo autor chama a atenção para a importância de desenvolver critérios que utilizem métodos apropriados para uma pesquisa qualitativa. Isso exige ter sempre em consideração a concepção de sujeito e as teorias que embasam o estudo em construção.

\subsection{Planejamento e realização da pesquisa}

Esta seção está dividida em três partes, correspondentes aos momentos do estudo. Inicialmente, descrevo as orientações básicas da Igreja Católica para a organização da formação dos candidatos para a vida religiosa consagrada. Isso porque tais orientações são importantes canalizações socioinstitucionais na sugestão de modos de ser e de sentir-se religioso. Em seguida, discorro sobre a realização do estudo piloto, apresentando os instrumentos de pesquisa utilizados e o processo de seleção dos participantes dessa etapa. Por fim, exponho a organização e realização do estudo principal, informando sobre a seleção dos quatro estudos de caso, bem como dos instrumentos de pesquisa.

\subsubsection{A vida religiosa consagrada}

Para caracterizar a Vida Religiosa Consagrada, bem como apresentar as etapas de formação pelas quais, em geral, passam os candidatos a esse modo de vida na Igreja Católica, busquei fundamentação no Código de Direito Canônico (em latim Codex Iuris Canonici). Trata-se do conjunto ordenado das normas jurídicas do direito canônico que organiza a Igreja Católica Romana, incluindo-se aí orientações sobre a formação de religiosos consagrados. Também nesse documento é possível encontrar: 1. esclarecimentos sobre a hierarquia de governo na Igreja Católica; 2. direitos e obrigações dos fiéis participantes dessa instituição, inclusive como religiosos consagrados; 3. sacramentos e sanções que se estabelecem pela transgressão das normas contidas nesse documento. 
O Código, como principal documento legislativo da Igreja, baseado na herança jurídica e legislativa da Revelação e da Tradição, deve considerar-se o instrumento indispensável para assegurar a ordem tanto na vida individual e social, como na própria atividade da Igreja. Por isso, além de conter os elementos fundamentais da estrutura hierárquica e orgânica da Igreja, estabelecidos pelo seu Divino Fundador ou baseados na tradição apostólica ou na mais antiga tradição, e ainda as principais normas referentes ao exercício do tríplice múnus confiado à própria Igreja, deve o Código definir também as regras e as normas de comportamento. (Código de Direito Canônico, 1983, pp. X-XI)

O Código de Direito Canônico é absolutamente necessário à Igreja. Já que ela também está constituída como um todo orgânico social e visível, tem necessidade de normas, para que a sua estrutura hierárquica e orgânica se torne visível, para que o exercício das funções a ela divinamente confiadas, especialmente a do poder sagrado e a da administração dos Sacramentos, possa ser devidamente organizado, para que as relações mútuas dos fiéis possam ser reguladas segundo a justiça baseada na caridade, garantidos e bem definidos os direitos de cada um, e, enfim, para que as iniciativas comuns, assumidas para uma vida cristã cada vez mais perfeita, sejam apoiadas, fortalecidas e promovidas mediante as normas canônicas. (Código de Direito Canônico, 1983, p. XII)

Nesse sentido, o Código de Direito Canônico (CDC) se mostra como um potente instrumento de canalização socioinstitucional no modo de ser e sentir dos fiéis cristãos. Tal canalização é acolhida e exigida de modo mais enfático entre as pessoas, homens e mulheres, que se candidatam a ser ou já são membros de uma ordem ou congregação religiosa, como os participantes deste estudo.

Em sua maioria, as ordens e congregações religiosas católicas (ou institutos de vida consagrada) existem desde os primeiros séculos da Era Cristã. São grupos de homens e mulheres congregados por um ideal comum, denominado carisma. Esse carisma é vivenciado e concretizado em diferentes atividades pastorais e religiosas. As mulheres e os homens pertencentes às ordens $\mathrm{e}$ congregações religiosas vivem em pequenos grupos (comunidade religiosa) e professam os votos de pobreza, castidade e obediência, tornando-se leigas consagradas. Tanto as ordens e congregações religiosas masculinas quanto as femininas podem ser de vida ativa (é o caso da Fátima, do Vicente e do Francisco) ou de vida contemplativa (é o caso da Cecília).

O que diferencia os religiosos das religiosas é que aqueles, além de proferirem os referidos votos e viverem a vida comunitária de acordo com uma regra aprovada pela Santa Sé (como as religiosas), podem ser clérigos, ou seja, ser ordenados padres. Assim, ao ser ordenado padre, o jovem passa a ser um clérigo regular (por seguir uma regra) e se obriga à administração dos sacramentos da Igreja Católica e às atividades pastorais de uma determinada paróquia. Porém, ele pode também escolher continuar leigo consagrado e não se ordenar padre (é o caso do Vicente). 
No código encontramos orientações e regulações sobre diversos assuntos relacionados ao modo de ser cristão, seguidor de Jesus Cristo. Entre tais assuntos focarei os que se referem à vida religiosa consagrada e às etapas de formação necessárias para esse modo de vida na Igreja. Essas etapas são comuns nos diferentes institutos de vida consagrada; em outras palavras, mesmo que esses institutos possuam Constituições, estatutos e normas particulares, estas estão sempre orientadas pelas normas gerais da Igreja Católica, presentes no CDC.

Cân. 578 - Por todos devem ser fielmente conservados a intenção e os propósitos dos fundadores sobre a natureza, fim, espírito e índole do instituto sancionados pela autoridade eclesiástica competente, e bem assim as suas sãs tradições; todas estas coisas constituem o patrimônio do mesmo instituto.

Cân. 587 - 1 . A fim de guardar mais fielmente a própria vocação e identidade de cada um dos institutos, no código fundamental ou constituições de cada instituto devem conterse, além daquelas coisas que no cân. 578 se ordena sejam observadas, as normas fundamentais concernentes ao governo do instituto e à disciplina, à incorporação e formação dos membros, e ainda ao objeto próprio dos vínculos sagrados.

§ 2. Tal código é aprovado pela autoridade competente da Igreja e só com o consentimento da mesma se pode alterar. (CDC, 1983, 107-108).

Assim, os institutos de vida consagrada, mediante suas constituições e normas próprias, buscam funcionar em harmonia com os desígnios da Igreja Apostólica Romana. Desenvolvem seus trabalhos pastorais e organizam sua formação sempre considerando esse macrocontexto institucional. Portanto, esse é um aspecto que aproxima os quatro estudos de caso desenvolvidos nesta investigação. Apesar de pertencerem a institutos de vida consagrada diferentes, os quatro estão orientados pelas mesmas regras e normas institucionais da Igreja Católica.

Por esse motivo, o CDC pode ser usado para fundamentar e esclarecer o significado de vida religiosa consagrada na Igreja Católica:

Cân. 573 - 1 . A vida consagrada pela profissão dos conselhos evangélicos é a forma estável de viver pela qual os fiéis, sob a ação do Espírito Santo, seguindo a Cristo mais de perto, se consagram totalmente a Deus sumamente amado, para que, dedicados por um título novo e peculiar à Sua honra, à edificação da Igreja e à salvação do mundo, alcancem a perfeição da caridade ao serviço do Reino de Deus e, convertidos em sinal preclaro na Igreja, preanunciem a glória celeste.

$\S$ 2. Assumem livremente esta forma de viver nos institutos de vida consagrada, canonicamente eretos pela autoridade competente da Igreja, os fiéis que, por votos ou outros vínculos sagrados, de acordo com as próprias leis dos institutos, professam observar os conselhos evangélicos de castidade, pobreza e obediência e pela caridade, a 
que os mesmos conduzem, se unem de um modo especial à Igreja e ao seu mistério [grifos do pesquisador]. (CDC, 1983, 106)

Os jovens que participam deste estudo são pessoas em formação para a vida consagrada, que buscam vivenciar e professar os conselhos evangélicos, seguindo as normas e regras de um instituto de vida consagrada. Eles professam que foi sob a ação do Espírito Santo que optaram por seguir Cristo mais de perto, consagrando-se totalmente a Deus - e deixando o convívio dos familiares para morar em um convento, sob a orientação das autoridades institucionalmente responsáveis. E assim, sob o título de irmão, irmã, freira ou padre, buscam a edificação da Igreja e a própria "perfeição da caridade no serviço do Reino de Deus".

A formação em cada instituto possui peculiaridades, mas todos, observando as regras gerais da Igreja Católica e de acordo com as próprias leis, professam observar os conselhos evangélicos mediante a vivência dos três votos religiosos: castidade, pobreza e obediência. Assim, unem-se de um modo especial à Igreja e ao seu mistério.

Cân. 590 - 1 1. Os institutos de vida consagrada, uma vez que estão dedicados de uma maneira particular ao serviço de Deus e de toda a Igreja, encontram-se por uma razão peculiar sujeitos à autoridade suprema da mesma.

$\S 2$. Todos e cada um dos seus membros estão obrigados a obedecer ao Sumo Pontífice, como a seu Superior supremo, mesmo em razão do vínculo sagrado de obediência. (CDC, 1983, 108)

As pessoas que desejam ingressar em um instituto de vida consagrada precisam, primeiramente, ser aprovadas e, então, seguir as normas de vida daquele instituto. Em geral, os candidatos à vida religiosa consagrada são adolescentes e jovens, o que não impede pessoas em idade adulta de procurar essas instituições com o intuito de ser religiosos consagrados. Desde que não tenham filhos menores de 18 anos e que não sejam casados, podendo ser viúvos ou viúvas, não há impedimento para fazer tal opção.

Ao se interessarem pela vida religiosa consagrada, os candidatos passam a ser vistos, e se veem, como vocacionados a esse modo de vida na Igreja (o sentido de vocação já foi apresentado na seção que discute a experiência vocacional religiosa como contexto de desenvolvimento). Portanto, esse caminho envolve um reposicionamento social e pessoal que, considerando os fundamentos teóricos deste estudo, deve ser observado como possibilidade de criação e transformação de sentidos de si e do mundo.

Como vocacionada, a pessoa busca uma aproximação de um instituto de vida consagrada, considerando que há diversos institutos, com diferentes carismas e modos de vida. O carisma é a identidade do instituto religioso, é o que o diferencia dos demais. Em geral, foi vivido primeiramente pelo fundador daquele instituto religioso, que, cativando outras pessoas, tornou-se um exemplo de vida a ser seguido. O carisma pode estar relacionado a diversos ações e contextos, 
como escola, oração, caridade ou missão. Em outras palavras, o carisma de uma instituição religiosa é o modo como ela busca vivenciar o cristianismo na sociedade na qual está inserida.

A pessoa vocacionada é inicialmente acompanhada por membros da instituição religiosa onde deseja ingressar. Esse acompanhamento também recebe o nome de discernimento vocacional. É um período em que os candidatos frequentam encontros, chamados encontros vocacionais, realizados pelas instituições com o intuito de possibilitar a eles reflexão sobre vocação religiosa, oração e informações sobre a história do instituto de vida consagrada. Assim, a fase do discernimento vocacional permite um conhecimento mútuo entre candidato e instituição religiosa, e o ingressar do jovem naquele instituto dependerá da concordância de ambas as partes.

Decidida a instituição religiosa e sendo aceito por ela, o candidato ingressa em uma casa de formação. Em geral, o primeiro ano morando no convento (ou seminário) é chamado "ano de postulantado", pois o candidato postula a vida religiosa. Viver a realidade da instituição religiosa é, assim, o modo de solicitar a admissão como seu membro efetivo. Esse ano em que o candidato ainda não é considerado membro oficial da instituição religiosa também funciona como uma aproximação entre vocacionado e instituto, favorecendo o discernimento vocacional. Sob a orientação de um mestre, membro efetivo da instituição, o candidato busca ter certeza se é essa sua vocação.

Finalizado o ano de postulantado, o candidato solicita ao superior do instituto de vida consagrada autorização para ingressar no noviciado. Segundo o Cânone 641 do CDC, "o direito de admitir ao noviciado pertence aos Superiores maiores, nos termos do direito próprio" $(1983,117)$. O noviciado é uma experiência importante para os candidatos à vida religiosa consagrada. Ao final desse período, que pode variar de 12 a 24 meses, eles professam publicamente os votos de pobreza, castidade e obediência. É a partir daí que são reconhecidos como membros oficiais da instituição religiosa e passam a ser chamados por título específico, em geral irmão, irmã, freira ou frade.

Cân. 646 - O noviciado, com que se inicia a vida no instituto, destina-se a que os noviços conheçam mais profundamente a vocação divina e também a própria do instituto, experimentem o modo de viver do instituto, informem a mente e o coração com o espírito deste, e se comprovem os seus propósitos e idoneidade [grifos do pesquisador]. (CDC, $1983,118)$

Ao final do noviciado, considerando especialmente o modo como o experimentam, os candidatos podem solicitar ao superior do instituto religioso autorização para professar os votos de pobreza, castidade e obediência. Durante o tempo de noviciado, o candidato é acompanhado de perto por um mestre de noviços, que avalia a comprovação dos propósitos e a idoneidade do candidato.

Cân. 650 — 1. A finalidade do noviciado exige que os noviços sejam formados sob a direção do mestre segundo as normas de formação determinadas pelo direito próprio. 
$\S 2$. O governo dos noviços é reservado exclusivamente ao mestre, sob a autoridade dos Superiores maiores.

Cân. $651-\S 1$. O mestre de noviços seja um membro do instituto, professo de votos perpétuos e legitimamente designado.

Cân. $652-\S 1$. Compete ao mestre e aos seus cooperadores discernir $e$ comprovar a vocação dos noviços, e formá-los gradualmente para virem a levar a vida de perfeição própria do instituto.

Cân. 653 - § 1. O noviço pode abandonar livremente o instituto; e por sua vez a autoridade competente do instituto pode despedi-lo.

$\S$ 2. Terminado o noviciado, se o noviço for julgado idóneo, seja admitido à profissão temporária; de contrário, seja despedido; se restar dúvida acerca da sua idoneidade, pode o Superior maior prorrogar o tempo de provação nos termos do direito próprio, mas não para além de seis meses [grifos do pesquisador]. (CDC, 1983, 119-120)

Tendo autorização do superior do instituto, que sempre ouve a opinião do mestre de noviços, os candidatos professam publicamente os votos religiosos. Esse momento celebrativo também é chamado de primeira profissão, profissão simples ou profissão temporária. $\mathrm{O}$ termo "temporário" é devido ao fato de que o agora religioso precisa renovar os votos a cada 12 meses, por 3 a 6 anos, prorrogáveis pelos superiores do instituto religioso até 9 anos. Depois desse tempo, o religioso solicita, novamente, ao superior do instituto de vida consagrada autorização para professar os votos perpétuos, ou seja, a profissão definitiva dos votos religiosos. E, a partir de então, os votos não precisam mais ser renovados. Valem por toda a vida e só podem ser revogados pela autoridade máxima da Igreja Católica, o Papa.

Cân. 654 - Pela profissão religiosa os membros assumem com voto público a observância dos três conselhos evangélicos, consagram-se a Deus pelo ministério da Igreja e são incorporados no instituto com os direitos e deveres determinados pelo direito. (CDC, 1983, 120)

Logo após a primeira profissão, o professo temporário é engajado nas atividades pastorais do instituto de vida consagrada. Daí em diante, a formação do então religioso, até a profissão perpétua, também é acompanhada por um ou mais mestres.

Cân. $659-\S 1$. Em cada instituto, depois da primeira profissão, complete-se a formação de todos os membros para viverem mais plenamente a vida própria do instituto e para prosseguirem mais adequadamente a missão deste. (CDC, 1983, 121)

Para além dos princípios comuns delineados até aqui, o modo como é conduzida a formação dos professos temporários varia de um instituto para outro, pois está diretamente relacionado com o carisma da instituição religiosa. Nesta breve caracterização da vida religiosa consagrada, optei por enfatizar as informações gerais, e não as especificidades de cada instituto de 
pertença dos participantes, com o intuito de preservar o anonimato das instituições religiosas envolvidas no estudo. Muitos institutos de vida consagrada são facilmente identificáveis por seu carisma e modo de participação na sociedade. De qualquer forma, o carisma de todo e qualquer instituto de vida consagrada está baseado nos ensinamentos evangélicos, como é possível verificar no Cânone 662 do CDC: "tenham os religiosos como regra suprema de vida o seguimento de Cristo proposto no Evangelho e expresso nas constituições do próprio instituto" $(1983,121)$.

\subsubsection{O estudo piloto}

O presente estudo iniciou com um aprofundamento, por parte do pesquisador, de pressupostos teórico-metodológicos da Psicologia Cultural do Desenvolvimento, bem como de perspectivas dialógicas do self. Foram várias leituras e discussões em busca de uma melhor compreensão do dialogismo como possibilidade de releitura dos processos de desenvolvimento de jovens vocacionados à vida religiosa consagrada.

Simultaneamente iniciei, via internet, uma busca pelos futuros participantes do estudo. $\mathrm{Na}$ página da Arquidiocese de Brasília (DF), consegui nomes, e-mails e números de telefone das congregações e ordens religiosas, masculinas e femininas, situadas no Distrito Federal. De modo aleatório, entrei em contato com algumas dessas instituições por telefone e por e-mail. Realizei o mesmo processo a partir da Arquidiocese de Goiânia (GO). Não recebi retorno de todas as instituições contactadas, mas sete se disponibilizaram a me receber para uma primeira reunião de esclarecimentos sobre os objetivos da pesquisa.

Das sete instituições que se interessaram em conhecer a pesquisa, três aceitaram participar do estudo, sendo uma do Distrito Federal e duas de Goiás. Esse procedimento possibilitou a submissão do projeto ao Comitê de Ética em Pesquisa do Instituto de Ciências Humanas da Universidade de Brasília, que o aprovou sob o número 783.168/2014.

Com o auxílio de minha rede pessoal, contatei jovens que já estavam em formação para a vida religiosa, ou seja, morando em uma casa de formação; e também adolescentes e jovens que estavam em momento de discernimento e acompanhamento vocacional, ou seja, ainda não haviam ingressado na instituição. Entrei em contato com esses vocacionados via e-mail e via Facebook, o que proporcionou criar uma rede de contatos e ter acesso a outros jovens vocacionados, em formação ou não.

No total, em Goiás e no Distrito Federal, consegui contato com 25 jovens, dos quais 20 puderam responder ao Guia de Evocação de Narrativas Escritas - GENE (Anexo IV). Esse instrumento, proposto como base para um estudo piloto, teve dois objetivos: 1. prover uma 
aproximação e um conhecimento exploratório do contexto de possíveis participantes do estudo, adolescentes e jovens católicos vocacionados à vida religiosa consagrada, em formação ou não; e 2. auxiliar na construção dos roteiros de entrevista, segundo o instrumento de pesquisa utilizado neste estudo.

Os critérios de seleção para a participação no estudo piloto foram dois: 1. que o adolescente ou jovem se sentisse vocacionado à vida religiosa consagrada e que, 2. de livre e espontânea vontade, pudesse responder ao GENE. O instrumento era um convite para que o adolescente ou jovem narrasse a história da própria vocação religiosa, destacando pessoas e experiências que julgasse importantes no processo de reconhecimento de si como vocacionado à vida religiosa consagrada. Esse procedimento foi realizado, individualmente, com 20 (vinte) participantes, entre adolescentes e jovens, de ambos os sexos, e com idade entre 16 e 30 anos. Alguns receberam e devolveram o GENE via e-mail, outros pessoalmente.

\subsubsection{O estudo principal}

Considerando informações e reflexões a partir de leituras dos GENEs, bem como sugestões da professora orientadora deste trabalho e das professoras participantes da banca de qualificação do estudo, algumas decisões foram tomadas para a realização da pesquisa:

1. incluir apenas jovens em formação para a vida religiosa consagrada, ou seja, jovens que moravam em um instituto de vida consagrada. Isso facilitaria o acesso aos participantes, considerando a intenção de entrevistá-los, no mínimo, duas vezes ao longo de dois anos;

2. selecionar participantes de congregações ou ordens religiosas distintas, a fim de deixar o jovem mais à vontade para partilhar informações referentes à vida cotidiana na casa de formação; e

3. incluir jovens que, ao longo da participação no estudo, experimentassem o noviciado. Essa terceira decisão foi uma maneira de buscar proximidade entre experiências dos participantes, considerando a vivência do noviciado um momento de transição pessoal e institucional importante naquele contexto. Cabe ressaltar que o noviciado finaliza com a profissão temporária dos votos, portanto é uma preparação para um reconhecimento institucional do jovem como religioso consagrado.

Considerando essas decisões, foram selecionados quatro participantes para o estudo principal: quatro estudos de caso. São dois homens e duas mulheres, membros de diferentes institutos de vida consagrada que, em 2014, ao iniciarem a participação no estudo, tinham entre 19 e 24 anos. Portanto, a seleção destes quatro jovens considerou os seguintes critérios: (1) que pertencessem a Congregações ou Ordens religiosas diferentes; (2) que estivessem na etapa de 
formação denominada noviciado ou ingressassem nesta antes da finalização do estudo empírico e, por fim, (3) concordasse em ser entrevistado, ao menos, duas vezes no decorrer de dois anos. Um deles já estava na etapa de formação noviciado e três ingressariam em, no máximo, quatro meses.

O estudo principal teve como instrumentos de construção de informações duas entrevistas narrativas individuais e presenciais: a primeira do tipo história de vida (Anexo V, utilizado com os quatro participantes) e a segunda do tipo episódica (roteiros individualizados, anexos VI, VII, VIII e IX). As entrevistas foram gravadas e realizadas individualmente, em local e horário negociados com os participantes. O Quadro 1 apresenta os quatro estudos de caso que compõem esta investigação e suas respectivas entrevistas:

\section{Quadro 1}

Participantes do estudo principal

\begin{tabular}{lllllll}
\hline & \multicolumn{3}{c}{ Primeira entrevista } & \multicolumn{3}{c}{ Segunda entrevista } \\
\cline { 2 - 7 } & Data & $\begin{array}{l}\text { Idade do } \\
\text { participante }\end{array}$ & $\begin{array}{l}\text { Tempo de } \\
\text { duração }\end{array}$ & Data & $\begin{array}{l}\text { Idade do } \\
\text { participante }\end{array}$ & $\begin{array}{l}\text { Tempo de } \\
\text { duração }\end{array}$ \\
\hline Cecília & $05 / 07 / 2014$ & 23 anos & $1: 05: 48$ & $16 / 02 / 2016$ & 24 anos & $1: 38: 42$ \\
\hline Fátima & $05 / 09 / 2014$ & 19 anos & $1: 36: 59$ & $09 / 02 / 2016$ & 20 anos & $1: 04: 45$ \\
\hline Francisco & $04 / 09 / 2014$ & 24 anos & $1: 21: 02$ & $17 / 12 / 2016$ & 25 anos & $1: 31: 10$ \\
\hline Vicente & $03 / 09 / 2014$ & 21 anos & $2: 54: 57$ & $30 / 01 / 2016$ & 22 anos & $1: 57: 51$ \\
\hline
\end{tabular}

Como uma construção psíquica e intelectual, narrar a própria história é representar fatos e acontecimentos que o sujeito seleciona a respeito de si, considerando contextos culturais e históricos. Segundo Goolishian e Anderson (1996), "os seres humanos são agentes conscientes, intencionais que se co-criam a si mesmos e a seu entorno numa permanente interação comunicativa com os demais" (p. 196). Dessa forma, a narração é um fenômeno intersubjetivo que resulta na criação e recriação constante de significados e realidades, tendo por base o diálogo e as interações simbólicas (Goolishian \& Anderson, 1996).

Ao iniciar a primeira entrevista, voltei a explicar os objetivos centrais do estudo, esclarecendo ao participante o interesse no conhecimento da gênese e história do seu desejo de ser um religioso consagrado. Assim, sugeri que fossem abordadas experiências vividas na infância, na adolescência, nos contextos da família, da escola e de grupos de amigos, bem como na aproximação, no ingresso e na permanência na instituição religiosa - momentos significativos de mudança e perspectivas em relação ao futuro.

Numa abordagem semiótica, a questão norteadora da entrevista bem como o esclarecimento dos objetivos da pesquisa canalizam a maneira como os participantes tecem a narrativa da própria trajetória de vida. Vários são os aspectos considerados na seleção de fatos e 
acontecimentos narrados. É provável que o participante opte por episódios que fazem sentido para ele na busca de justificar o porquê de ser quem é, ter chegado aonde chegou etc. - no caso desta pesquisa, o porquê de estar vivendo em uma instituição católica de vida consagrada. Sobre essa atitude ativa e responsiva do ouvinte, Bakhtin (1992) ressalta que,

de fato, o ouvinte que recebe e compreende a significação (liguística) de um discurso adota simultaneamente, para com o discurso, uma atividade responsiva ativa: ele concorda ou discorda (total ou parcialmente), completa, adapta, apronta-se para executar etc., e esta atitude do ouvinte está em elaboração constante durante todo o processo de audição e de compreensão desde o início do discurso, às vezes já nas primeiras palavras emitidas pelo locutor (p. 290).

Portanto, o momento de entrevista é marcado por negociações semióticas, construções de significados entre pesquisador e participante. Este último seleciona fatos e acontecimentos da sua trajetória que, de certa forma, correspondam às expectativas do pesquisador e aos objetivos da pesquisa, revelados ao participante e interpretados por ele.

Por um lado, as entrevistas abordaram a trajetória de desenvolvimento dos participantes de modo retrospectivo; por outro, possibilitaram construir informações sobre sentimentos experienciados e expectativas sobre acontecimentos futuros. Nesse sentido, a ênfase recai sobre as mudanças vividas num tempo irreversível, especialmente sobre transições de desenvolvimento, ajustes e desajustes na relação eu-outro. A partir das narrativas dos participantes, busquei analisar as expectativas futuras e a trajetória de desenvolvimento vivida e imaginada, no intuito de apreender dinâmicas de transformações (movimentos) no sistema de self.

A segunda entrevista narrativa individual ocorreu entre 15 e 19 meses após a realização da primeira. As experiências do sujeito acerca de um tema podem ser lembradas nas formas de conhecimento narrativo-episódico e semântico (Flick, 2004; McAdams, 2001; Murray, 2008), por isso essa entrevista foi do tipo episódica. Os episódios foram selecionados pelo pesquisador, levando em consideração as informações obtidas nos dois momentos anteriores (narrativa escrita e entrevista do tipo história de vida). Na segunda entrevista, apenas uma participante ainda estava no noviciado; os outros três já haviam concluído essa etapa.

Um último encontro individual foi realizado com os quatro participantes do estudo principal, no mês de fechamento da tese, para apresentar as informações até então construídas bem como os resultados ainda em aberto das análises. Antes da elaboração das considerações finais do estudo, buscou-se ter, novamente, os participantes como parceiros na pesquisa. Na oportunidade, o participante ouviu e opinou sobre as informações construídas relacionadas à sua participação no estudo. Acredito que essa metodologia avança na busca de aprofundar estudos de caso e contribui para pensar aspectos particulares e gerais da dinâmica configuração do self na adolescência e 
juventude. Ela também pode proporcionar um olhar mais amplo sobre o fenômeno, considerando não só a perspectiva do investigador, mas também a perspectiva dos participantes.

Um diário de campo foi utilizado pelo pesquisador para registros complementares, realizados logo após cada entrevista. Esse foi um importante instrumento no registro de atitudes, comportamentos, gestos e outros aspectos metacomunicativos percebidos nos momentos de interação entre pesquisador e participante. Tais informações auxiliaram na análise das informações. No diário de campo, também foram registradas reflexões, questionamentos e insights do pesquisador ocorridos durante e após os encontros com os participantes.

Este estudo buscou discutir processos de desenvolvimento e transições juvenis, considerando a experiência religiosa como contexto de desenvolvimento dos jovens vocacionados. É importante ressaltar que a experiência religiosa se inicia antes do ingresso do jovem na ordem ou congregação. Portanto, experiências não apenas em relação à religiosidade, vividas antes de o jovem tornar-se um vocacionado à vida consagrada, também importam, pois orientam, de modo afetivo, experiências vividas no presente, bem como expectativas relacionadas aos futuros imaginados. Da mesma forma, as experiências vividas no presente, bem como os novos significados e reposicionamentos dos jovens ao ingressarem em uma instituição religiosa, possibilitam novas leituras de si, do outro, do seu passado e das possibilidades de futuro.

\subsection{Procedimentos éticos na realização da pesquisa}

Tanto os representantes das intituições religiosas como os participantes, ao serem contactados, receberam os esclarecimentos necessários sobre os objetivos da pesquisa e sobre como seria sua participação. Tais esclarecimentos seguiram as prerrogativas éticas da pesquisa com seres vivos, preconizadas pelas resoluções 196/1996 e 466/2012, do Conselho Nacional de Saúde, bem como as resoluções 016/2000 e 023/2007, do Conselho Federal de Psicologia, que tratam de normas da área de psicologia para a pesquisa com seres humanos. Sanadas as dúvidas, os participantes assinaram o aceite institucional, que foi exigência do comitê de ética para a submissão do projeto. Além do aceite institucional, foi entregue ao comitê de ética o Termo de Consentimento Livre e Esclarecido (TCLE). Tanto o aceite institucional quanto o TCLE foram assinados em duas vias, ficando uma com o participante/representante da instituição e outra com o pesquisador.

Ao início de cada encontro com os participantes, foi lembrada sua total liberdade de não responder ou comentar qualquer questão que lhe causasse incômodo, bem como o direito encerrar sua participação no estudo a qualquer momento, sem prejuízo à sua pessoa. Também foi lembrada a garantia de anonimato tanto dos jovens quanto das instituições às quais pertenciam. Por fim, cabe 
lembrar o compromisso firmado pelo pesquisador, tanto com as instituições religiosas quanto com os jovens participantes do estudo, de uma devolutiva do estudo, que será agendada logo após a defesa da tese.

\subsection{Equipamentos e material}

$\mathrm{Na}$ realização das entrevistas, foram utilizados dois gravadores de áudio. Para ouvir e transcrever as entrevistas foi usado um computador, de propriedade do próprio pesquisador. E, como diário de campo, um caderno contendo duzentas folhas pautadas.

\subsection{Procedimentos utilizados na organização e análise das informações}

As informações construídas nesse processo de investigação foram organizadas em duas partes interligadas. Na primeira, ouvi as entrevistas do tipo história de vida repetidas vezes, antes de começar a transcrevê-las. Esse procedimento proporcionou uma visão ampla da organização das narrativas. Considerando os objetivos do estudo, busquei perceber informações importantes e os vários modos como eram expressas: tempo gasto pelo participante para contá-las; ênfase dada por meio de tom de voz ou repetição de frases; uso de palavras que expressavam emoções; pausas diante de algumas informações; mudanças de assunto não solicitadas etc. Ao transcrever as primeiras entrevistas, destaquei alguns episódios a serem aprofundados no segundo momento de entrevista. Logo depois, comecei a ensaiar análises a partir de leituras cruzadas entre 1. os pressupostos teóricos que fundamentam este estudo; 2. informações e reflexões surgidas com o estudo piloto; e 3. informações resultantes do primeiro momento de entrevista.

$\mathrm{Na}$ segunda parte, realizei um processo semelhante: ouvi repetidas vezes as entrevistas episódicas, destaquei informações importantes e transcrevi todas elas. Depois, mediante repetidas leituras do material, busquei por sentidos e significados que pareciam direcionar atitudes, comportamentos, modos de ser e de sentir dos participantes. Juntando informações contidas nas duas entrevistas, comecei a focar e analisar movimentos semióticos e tensões dialógicas em relação a rupturas e transições vivenciadas pelos jovens. Nesse processo, destaquei reposicionamentos sociais e pessoais narrados nas entrevistas. Em especial, uma pergunta feita aos quatro participantes, no final da segunda entrevista, se mostrou importante: caso tivessem que desenhar a história de suas vidas em quatro quadrinhos, o que apareceria em cada um deles? 
Nas discussões dos movimentos semióticos e tensões dialógicas, foram destacados complexos semióticos que se mostraram orientadores e organizadores das narrativas dos participantes. Portanto, considerando a idiossincrasia e a singularidade dos casos, busquei, na organização dessas narrativas, identificar marcas definidoras, bem como signos hipergeneralizados que, de alguma maneira, canalizavam as experiências do sujeito no seu processo histórico.

Dessa forma, na apresentação dos resultados e nas discussões dos quatro estudos de caso, tais marcas e signos hipergeneralizados direcionaram os caminhos de análise da seguinte forma: no caso Cecília, ganha destaque o modo como a jovem organiza seu sistema de self em diálogo com determinadas esferas de experiência; no caso Fátima, as narrativas destacam complexos semióticos organizados em função de recursos simbólicos institucionalizados; o Francisco orienta a organização do seu sistema de self muito em função da fronteira entre um dentro e um fora do convento, considerando sua peculiar condição de saúde; por fim, o Vicente narra um modo de ser e de sentir no mundo, tornando o futuro, como elemento em aberto, aspecto central na organização da experiência do presente. 


\section{RESULTADOS E DISCUSSÃO}

Este é um estudo longitudinal sobre transições de desenvolvimento à luz da experiência de quatro jovens em formação para a vida religiosa consagrada. Com base na perspectiva semióticocultural e considerando a ótica dos próprios participantes, são interpretadas informações construídas em situação de entrevista. Assim, a compreensão de condições de internalização de sentido e movimentos de externalização ocupa lugar de destaque na investigação.

Como apresentado no capítulo metodológico, este estudo teve como espaço principal de construção das informações dois momentos de entrevista: uma do tipo história de vida e outra episódica. A partir de tais informações, analiso quatro estudos de caso: caso Cecília, caso Fátima, caso Francisco e caso Vicente.

É importante lembrar que cada participante é membro de uma instituição religiosa diferente e as quatro instituições possuem características que as assemelham e as diferenciam entre si. Nesse sentido, como foi apresentado na contextualização da vida religiosa consagrada, o carisma das congregações e a dinâmica da formação são aspectos que diferenciam as instituições religiosas das quais os jovens fazem parte.

Este capítulo relata as quatro histórias de vocação religiosa, com suas particularidades pessoais e institucionais. Buscando alcançar os objetivos do estudo, bem como a clareza do processo de construção das informações, a dinâmica de apresentação e discussão dos resultados tomou o seguinte caminho: 1. apresentação dos momentos de construção de informações; 2. caracterização do caso; e 3. discussão de movimentos semióticos e tensões dialógicas na trajetória de vida do sujeito.

\subsection{Caso Cecília: a organização do sistema de self a partir do diálogo com as esferas de experiência}

6.1.1 Momentos de entrevista e construção de informações

Em junho de 2014, contatei via e-mail a superiora de um convento de religiosas, apresentando o objetivo do estudo e solicitando que o convite para a participação de uma jovem na pesquisa chegasse até as possíveis participantes. O primeiro contato foi feito com a superiora considerando que os candidatos e candidatas à vida religiosa, ao ingressarem no convento, devem 
prestar obediência a ela, que é responsável pela casa de formação e pela própria formação dos jovens.

A madre ${ }^{1}$, após conversar com a Cecília, que aceitou o convite, respondeu ao meu contato. Meu primeiro encontro com a Cecília ocorreu em 18 de junho de 2014, na instituição religiosa onde ela morava. Na oportunidade, expliquei os objetivos do estudo e solicitei a assinatura do Termo de Consentimento Livre e Esclarecido (TCLE). Falei sobre a metodologia da pesquisa e os possíveis encontros que teríamos pela frente. Deixei com ela o Guia de Evocação de Narrativas Escritas, voltando para buscá-lo uma semana depois.

A primeira entrevista com a jovem ocorreu no segundo encontro, em 5 de julho de 2014. $\mathrm{Na}$ época, Cecília estava com 23 anos e residia naquela instituição havia quase um ano. Conversamos sobre a trajetória da sua vocação, abordando questões contexto familiar, infância, adolescência, vida escolar, trabalho e ingresso no convento.

A segunda entrevista com a jovem foi realizada em 16 de fevereiro de 2016 (roteiro utilizado em anexo VI). O foco foram eventos ocorridos após a primeira entrevista, especialmente a entrada da Cecília no noviciado, sua tomada de hábito e sua mudança de nome, quando passou a ser chamada pelo nome religioso. Na oportunidade, retomamos alguns episódios narrados na primeira entrevista em busca de esclarecê-los.

Dos quatro estudos de caso, a Cecília foi a única participante com a qual não tive nenhum contato no intervalo entre a primeira e a segunda entrevista. Com os demais, mantive contato, mais ou menos regular, via e-mail, Facebook, Whatsapp e Skype. Diferente dos outros, a Cecília não tinha acesso a essas redes sociais, por isso não foi possível estabelecer com ela esta regularidade de contato.

\subsubsection{Caracterização do caso}

Cecília cresceu em uma família composta por ela, a mãe, o pai e um irmão. Segundo Cecília, uma família pobre e sempre unida. Moraram em diferentes localidades até a aquisição da casa própria, quando Cecília tinha 11 anos, que ela destaca como um acontecimento importante para a família.

1 Título que se dá, nos conventos, à freira, religiosa professa solene, que é autoridade e responde simbólica e juridicamente por uma comunidade religiosa. A madre é eleita em votação pelas próprias coirmãs. 
Cecília se considera uma pessoa tímida e recatada desde criança. Aos 13 anos, desejosa de ter seu próprio dinheiro, resolveu ser manicure das amigas. Aos 14, conseguiu seu primeiro emprego com carteira assinada em uma agência bancária no prédio do Ministério Público da União (MPU). Ali, segundo a jovem, surgiu o desejo de ser funcionária pública concursada do MPU, motivo pelo qual começou a fazer cursinho preparatório, ao mesmo tempo que trabalhava e cursava o ensino médio. Estudou para a prova do MPU durante cinco anos, tempo em que esteve namorando um rapaz que também se dedicava a estudar para concurso público.

Realizou a prova do MPU aos 18 anos, mas não conseguiu aprovação, fato que a deixou desmotivada na continuação dos estudos para concurso. Vencendo o contrato com a agência bancária, foi trabalhar em um hospital, distanciando-se ainda mais do ambiente de serviço público. Naquela época, convidada por um amigo, conheceu um grupo de jovens que se reunia na igreja paroquial próxima a sua casa. O grupo desenvolvia um trabalho voluntário designado Pastoral de Rua: pedia alimentos no comércio local e preparava sopa para ser distribuída aos moradores de rua. Cecília se interessou pelo trabalho dos jovens e começou a acompanhar o grupo no preparo e na distribuição da sopa.

Segundo a jovem, naquele momento, mais distante da possibilidade de ser funcionária pública concursada e mais envolvida com o grupo de jovens no trabalho voluntário, pela primeira vez ocorreu-lhe a possibilidade de ser freira. Com essa curiosidade, buscou orientação do padre daquela paróquia. Queria entender melhor sobre vocação religiosa, bem como os passos a serem seguidos para ingressar no convento. Desde então, esse mesmo padre tornara-se o seu diretor espiritual ${ }^{2}$. Ao comentar suas novas intenções com a família, notou que sua mãe não apresentara resistência, mas também não a incentivou. Já o pai e o irmão desde o início se posicionaram contrários.

No processo de aproximação à ideia de adotar a vida vocacional, Cecília conheceu duas congregações religiosas, uma de vida ativa ${ }^{3}$ e outra de vida contemplativa ${ }^{4}$. Não se identificou com o carisma das freiras de vida ativa e, ao contrário do que imaginava, sentiu-se muito atraída pelo estilo de vida das freiras contemplativas. Decidiu, então, iniciar com elas um período de

2 A direção espiritual consiste em conhecer um pouco da vida da pessoa que recebe a direção, visando auxiliar no processo de amadurecimento espiritual e superar os obstáculos no desenvolvimento espiritual, segundo a tradição católica.

3 Congregações de vida ativa possuem como carisma, ou missão, viver os valores evangélicos no trabalho direto com as comunidades. Seus membros vivem em conventos e, em geral, atuam em atividades externas em colégios, pastorais paroquiais, organizações sociais e hospitais, entre outros.

$4 \quad$ Congregações de vida contemplativa possuem como carisma viver os valores evangélicos na clausura, ou seja, seus membros vivem parcial ou completamente enclausurados, dedicados ao trabalho e à oração. 
acompanhamento no intuito de discernir sua vocação, ou seja, confirmar se era isso o que queria para sua vida.

Uma semana após Cecília conhecer a instituição religiosa de vida contemplativa, sua mãe veio a falecer, o que mudou muito a dinâmica da família. Cecília decidiu abandonar por um tempo o discernimento vocacional, bem como o acompanhamento espiritual a que vinha se submetendo, uma vez que o pai e o irmão precisavam mais dela naquele momento.

A jovem conta que, embora ainda sentisse o desejo de ser freira, resolveu reatar o relacionamento com o antigo namorado, de quem ficou separada por quase um ano. Vivenciou essa ambivalência por seis meses e, depois de conversar com o diretor espiritual, terminou o namoro. $\mathrm{Na}$ mesma ocasião, voltou a buscar o acompanhamento vocacional das irmãs de vida contemplativa e a participar dos encontros vocacionais. A notícia do fim do namoro e a reaproximação do convento foi motivo de desentendimentos entre a Cecília e o pai, que a acusou de querer abandonar a família em momento tão difícil. Contudo, ela continuou a frequentar a instituição religiosa, onde ingressou formalmente aos 22 anos, um ano antes do nosso primeiro contato.

$\mathrm{Na}$ primeira entrevista, Cecília estava prestes a vivenciar um rito de passagem muito importante naquele contexto: a tomada de hábito. Esse rito é a celebração de uma missa em que a candidata à vida religiosa naquela instituição recebe as vestes oficiais da congregação (o hábito religioso), que passarão a ser usadas sempre como um sinal da sua consagração e pertença à instituição. Na mesma cerimônia, dois outros acontecimentos seriam celebrados: o início do noviciado e o anúncio do nome religioso da jovem. $\mathrm{O}$ nome religioso traz uma missão a ser assumida pela futura religiosa, durante sua formação e após sua consagração, mediante as profissões simples e perpétua.

Ao ser entrevistada pela segunda vez, a Cecília já havia vivenciado sua tomada de hábito, portanto, usava as vestes oficiais da congregação, era noviça e atendia pelo nome religioso. Assim, o segundo encontro de pesquisa teve como foco essas mudanças e seus significados para a jovem. A seguir, considerando os objetivos e o arcabouço teórico-metodológico da pesquisa, apresento e discuto transições de desenvolvimento na trajetória de vida da Cecília, a partir do diálogo entre esferas de experiência e complexos semióticos identificados nas narrativas da jovem.

\subsubsection{Movimentos semióticos e tensões dialógicas na trajetória de vida da Cecília}

As narrativas da jovem Cecília apresentam diversos processos de ruptura-transição que devem ser investigados de modo dialógico na sua trajetória de vida. Na primeira entrevista, ela narra vários eventos mobilizadores de rupturas, que desencadeiam processos singulares de 
desenvolvimento: aquisição da casa própria pela família, decisão de buscar o primeiro emprego, ingresso no mundo do trabalho, decisão de estudar para concurso público, mudança para a casa de uma amiga, reprovação no concurso público, inserção no grupo de jovens, decisão de ser freira, falecimento da mãe, rompimento do namoro, ingresso no convento, adaptação à pedagogia de formação do convento. Considerando a importância dos momentos de ruptura-transição no desenvolvimento do sujeito, é preciso frisar que os signos são históricos, possuem uma historicidade, formam e se transformam num tempo irreversível, a partir do encadeamento dialógico entre presente, passado e futuro.

Passo a focar agora movimentos de ruptura-transição da jovem Cecília, considerando complexos semióticos em diálogo com três esferas de experiência destacadas por ela na organização das suas narrativas: o mundo do trabalho, o grupo de jovens da Pastoral de Rua e a instituição religiosa. Com isso, são discutidas tensões no interior dessas esferas de experiência, bem como tensões estabelecidas entre elas. É premissa do estudo que novas e diferentes esferas de experiência possibilitam a produção de sentidos, resultando em (e exigindo) novas reorganizações do sistema de self da pessoa. Contudo, são focadas as rupturas que ganharam destaque na narrativa da Cecília, investigando processos de desenvolvimento e a construção de significados inéditos.

\subsubsection{Esfera de atividade "mundo do trabalho"}

Cecília marca a transição para a adolescência a partir do fato de, aos 13 anos, perceber-se querendo trabalhar e ganhar o próprio dinheiro: "realmente uma mudança considerável foi nos meus 13, 14 anos, que eu queria porque queria trabalhar". Naquele momento, emergia um novo ciclo de produção de sentidos sobre si e sobre o mundo, possibilitando a novidade no sistema de self da garota. Negociações dialógicas operam na busca de uma coerência entre suas metas pessoais e as possibilidades e limites do seu campo de ação: "não, eu vou fazer alguma coisa pra trabalhar [...] eu quero ser independente, eu quero fazer as minhas coisas [...]. Comecei a fazer unha das amigas". Num autodiálogo, sintetizado pela palavra "não" no início do trecho citado, a posição de adolescente com limitações financeiras e materiais é negada pela de adolescente que pode fazer algo por si mesma e ser independente.

Novos ciclos de sentido emergem ancorados em sentidos já existentes (Peirce, 1955; Valsiner, 2012) e dentro de limites e possibilidades socialmente oferecidos. A busca de Cecília por independência, mediante o trabalho, deve ser compreendida como significado em meio a crenças e possibilidades socialmente reforçadas - por exemplo, de que o jovem pode e precisa ter o próprio dinheiro, o que lhe dá direito de escolha, de "fazer as minhas coisas". 
Para além desse contexto social macro, o ambiente familiar da Cecília é um espaço importante de sugestões e construções de sentidos referentes ao mundo do trabalho: "família simples, humilde, né? De situação financeira baixa. [...] 8, 9 anos, eu tinha que me virar sozinha, porque minha mãe ia pra um lado, meu irmão também estudava. [...] Então assim, desde criança eu já tinha que me virar só". Portanto, a posição de self “eu, trabalhadora” sugere uma ancoragem em experiências vivenciadas por Cecília no mesocontexto doméstico: "eu, filha de pai doente", "eu, filha de mãe trabalhadora", "eu, de família humilde", “eu, tendo que me virar só”. Na relação dialógica com os contextos, constroem-se sentidos de si, e posições de eu emergem em diálogo com sistemas de valores socialmente disponíveis e enfatizados.

No entanto, entre o sujeito e o ambiente, este envolvendo pessoas, objetos, símbolos, valores morais, há uma constante "tensão irredutível" (Wertsch, 1998). Em outras palavras, os contextos culturais não são reduzíveis aos símbolos e às formas de representação convencionadas e compartilhadas; entre os espaços reais e as formas simbólicas da cultura há sobretudo tensões e contradições, fontes de constantes negociações dialógicas em que novos processos semióticos têm lugar. Tais tensões e contradições possibilitam uma relação entre continuidade e mudança na (re)construção dos significados e dos valores culturais pela pessoa. É na vivência dessas ambivalências que Cecília cria um ciclo de produção de sentidos relacionados ao mundo do trabalho, à adolescência e ao futuro, o que exige dela (ao mesmo tempo que possibilita) agir com certo protagonismo para alcançar sua "independência".

Ao valorizar os sentidos de liberdade, trabalho e independência financeira, Cecília organiza um sistema hierárquico de sentidos semióticos, e então os sintetiza num posicionamento "eu, trabalhadora". A hierarquização de sentidos opera mediante o mecanismo denominado "abstração generalizante" (Valsiner, 2008). Ao criar ferramentas semióticas reguladoras, como o signo independência, Cecília diminui tensões tanto na significação da experiência presente como na adaptação aos novos contextos, podendo facilitar, por exemplo, sua inserção no mundo do trabalho.

Ao ingressar no estágio, aos 14 anos, Cecília cria, amplia e ressignifica sentidos em relação ao mundo do trabalho. Amparada nas relações inéditas que estabelece na esfera de experiência, organiza novos níveis reguladores semióticos. A posição "eu, trabalhadora" se transforma em "eu, empregada", evidenciando que os significados se desenvolvem (Pierce, 1955), possuem uma historicidade. A partir de então, o contexto do órgão público funciona como importante esfera de experiência em torno da qual o sistema de self de Cecília vai se reorganizar, numa perspectiva de futuro: "eu gostava muito do ambiente de trabalho e das pessoas, então eu falei assim: "eu vou estudar pra voltar pra cá'. Porque era só estágio". As relações no ambiente do órgão público funcionam como novas sugestões sociais e operam como andaimes na criação e no fortalecimento de ciclos de produção de sentidos referentes à busca por independência. Em meio aos novos processos semióticos ali estabelecidos, Cecília faz sínteses pessoais inéditas e reorganiza uma 
hierarquia de sentidos, possibilitando a emergência de signos em um nível superior de simbolização (Figura 1).

Figura 1. Complexo Semiótico Relacionado ao Futuro Profissional da Cecília

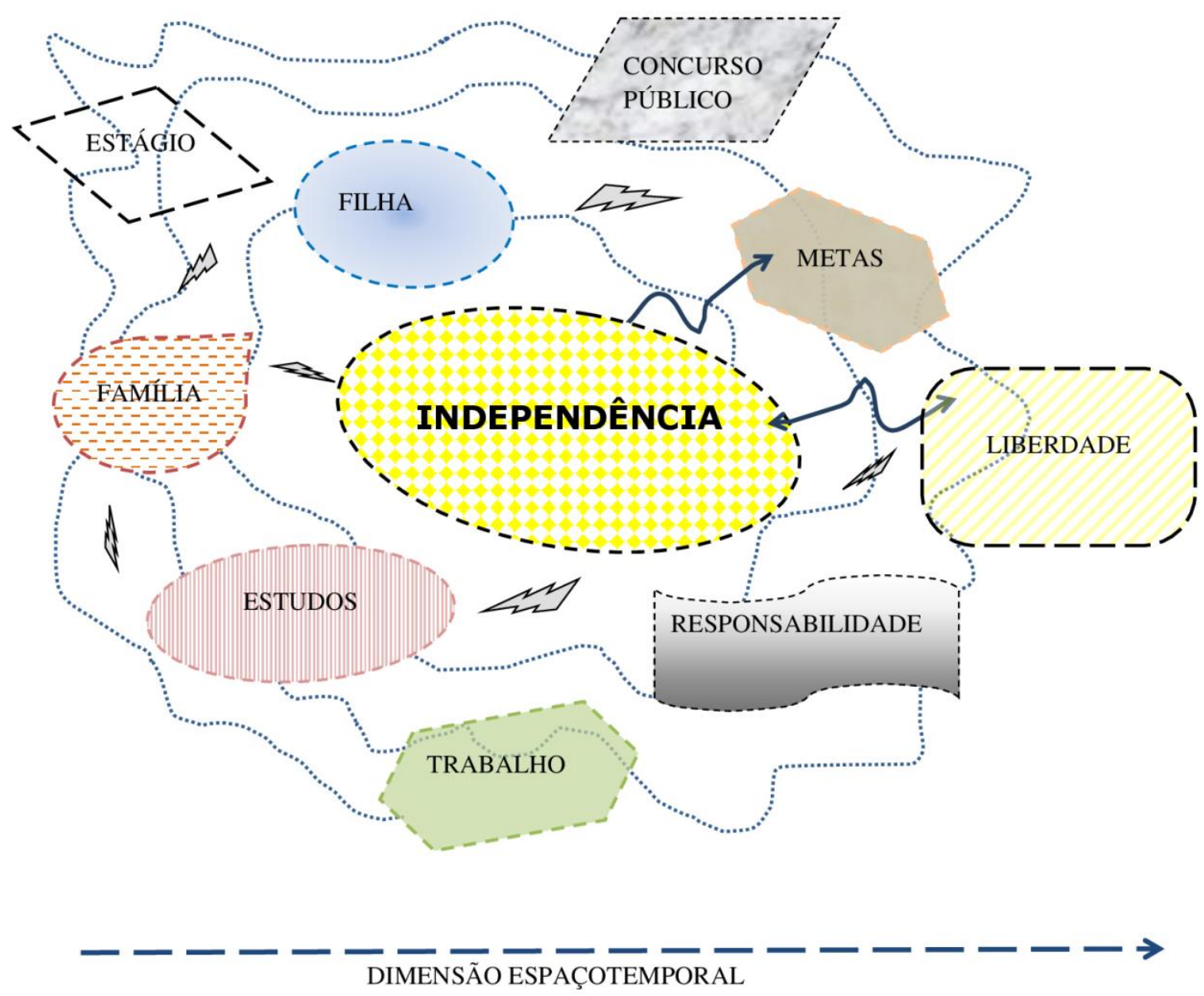

Fonte: Elaboração do pesquisador

$\mathrm{Na}$ Figura 1, em que aparece o contexto semiótico relacionado ao mundo do trabalho, o metassigno (Valsiner, 2012) "independência" opera na regulação, orientação e organização das relações com e entre signos em níveis inferiores de simbolização. Dada a organização sistêmica da psiquê, tal metassigno afeta o agir e sentir da Cecília em todas as esferas de experiência, como a escolar e a familiar.

Numa reorganização do complexo semiótico coordenado pelo signo hipergeneralizado "independência”, emerge uma I-position inédita: “eu, servidora pública”. Esta passa a funcionar 
como uma metaposição projetada num horizonte futuro, direcionadora de escolhas, ações e posicionamentos: "Era minha meta [...] também por influência ali do trabalho, né?"

Nesse momento, o órgão público torna-se uma importante esfera de experiência na orientação do sistema de self da Cecília. Os valores e as crenças disseminadas naquele ambiente vão ao encontro dos que são valorizados por ela, dialogam com suas expectativas de "independência". Em outras palavras, tal contexto oferta ferramentas simbólicas que funcionam como prótese na ampliação de recursos psicológicos, permitindo a Cecília uma nova regulação e orientação do seu estar no mundo.

Para além de um desenvolvimento cognitivo e intelectual, a consciência de si e do mundo da Cecília se constitui mediante a afetividade, as emoções, os desejos e as motivações, e assim, é orientada e orienta relações nos contextos, o que canaliza ações em um mundo de significados (Branco \& Valsiner, 1997): “estudava de manhã, trabalhava à tarde e fazia cursinho à noite [...]. Minha perspectiva era passar em concurso e fazer a faculdade de direito, porque eu estudava naquele ramo". A metaposição "eu, servidora pública" era constantemente reforçada pelo ambiente institucional. Segundo ela, "no órgão público todo mundo fala nisso [em concurso público]", que lhe pareceu um caminho possível também para alcançar seus interesses pessoais, significativamente canalizados pelas necessidades e pelos interesses da família: "eu queria muito que minha mãe deixasse de trabalhar, que meus pais tivessem uma vida melhor. Então, assim, eu visava muito isso, o bem da minha família. [...] E também a minha liberdade".

A inserção da Cecília no mundo do trabalho envolveu três processos interdependentes, presentes no fenômeno ruptura-transição (Zittoun, 2006a): 1. processos identitários, reposicionamentos intrapessoais e interpessoais, novos modos de se ver e ser vista nos contextos familiar, escolar e profissional; 2. processos de aprendizagem, novos saberes, habilidades e competências construídos e reposicionamentos no campo social; e 3. processos de construção de significados e sentidos de si e do mundo.

Em geral, a emergência de uma nova metaposição e de novos sentidos reforçados numa esfera de experiência tem consequências significativas em outras esferas. No caso da Cecília, observamos que a possibilidade de futura servidora pública concursada possibilita novos posicionamentos, como "eu, estudante comprometida, dedicada e responsável". O sujeito cria significados em busca de fazer um futuro imaginado acontecer:

em casa, eu quase não ia em casa, ia pra dormir praticamente [...], por causa do trabalho. Acho que a gente fica mais independente. "Eu quero fazer isso e pronto, vou fazer. Eu tenho o meu dinheiro". [...] Fiquei um pouco rude em casa, ali, coisa de adolescente. [...] Estudei assim muito, fiz tudo que eu podia. Saí de casa também [...] e fiquei onze meses, onze meses antecedentes à prova [...], estudava dia e noite, deixava de ir... pra igreja até! Sair com os amigos [grifos do pesquisador]. (primeira entrevista) 
Cecília diz que sua adolescência é marcada pelo desejo de ser servidora pública, concursada e independente, e talvez por isso ela marque o início dessa fase com o desejo de trabalhar e ter o próprio dinheiro. É como se a esfera de experiência órgão público, com seus valores e campos de significados, em diálogo com o complexo semiótico (Figura 1), coordenasse ações, pensamentos e comportamentos da Cecília naquela e em outras esferas de experiência, como a família, a escola e a igreja. Significados de si e do mundo dialogam numa relação de auto e heterorregulação (Valsiner, 2012), orientados pelo signo hipergeneralizado "independência" e em diálogo com a posição de self possível "eu, futura funcionária pública concursada". Nesse sentido, o signo hipergeneralizado "independência" e a posição de self possível sugerem tonalidades na significação de signos como meta, filha, responsabilidade, família, presente, futuro, liberdade, estudos, estágio.

Significados ou dispositivos semióticos são criados pela psiquê humana de modo criativo, constante e hiperprodutivo. Muitos desses dispositivos são abandonados antes de ser utilizados ou depois do uso, quando já não são necessários. Outros se fazem presentes e atuantes na ontogênese e, até mesmo, na história cultural e humana (Valsiner, 2012).

Aos 18 anos, Cecília sai de casa para morar com uma amiga, com a intenção de estar mais próxima do cursinho e do trabalho, e assim perder menos tempo nos deslocamentos.

Saí de casa também, fiquei um ano fora, isso marcou também minha adolescência. Esqueci de falar. É... aí, quando eu fiz 18 anos, eu saí de casa só pra estudar. [...] Tinha uma amiga que morava ali, em frente o cursinho. [...] Então eu saí de casa e fiquei onze meses, onze meses antecedentes à prova, ao concurso. Então marcou muito isso, porque hoje eu... hoje eu vejo que não valeu a pena. Mas Deus sabe por que que eu saí [grifos do pesquisador]. (primeira entrevista)

Aqui há uma sugestão de que este sair da casa dos pais não foi uma ruptura tão signficativa na vida da Cecília naquela época, quando tinha como metaposição "eu, servidora pública". Porém, quando esta já não era mais uma metaposição na coordenação de outras posições de eu, quando a jovem já morava no convento havia quase um ano, a Cecília interpreta esse fato como marcante na sua adolescência: "hoje eu vejo que não valeu a pena". Uma escolha que the parecia necessária e importante para alcançar seus objetivos passa a ser avaliada como algo "que não valeu a pena". Num tempo irreversível, o sujeito transforma hierarquias de valores, modificando seu modo de fazer sentido de si e do mundo, tendo o presente como espaço de emergência de novos sentidos do passado e do futuro.

No nível mesogenético, os contextos do cursinho e do órgão público funcionam como importantes cenários com sugestões e atividades relativamente repetidas que molduram as ações da Cecília, canalizando sua experiência subjetiva, sugerindo e legitimando possibilidades de concretização de uma realidade futura imaginada e desejada. Cecília organiza seu presente em 
função de um futuro possível, antecipa mais que recorda, projeta mais que convoca o passado. Com a reprovação, esse agir e sentir no presente (dedicação aos estudos) se tornam desprovidos de significado, visto que o futuro possível, o ser funcionária pública concursada, não se concretiza do modo esperado.

Aí então fiz a prova, decorridos esses cinco anos, e não passei. Por um ponto e meio, né? Faltou um ponto e meio, só, pra eu passar na média. Aí então, assim, eu não entrei em desespero, mas fiquei muito decepcionada por ter me dedicado tanto. Me dediquei tudo que eu podia.

Essa ruptura-transição na trajetória de vida da Cecília exige dela novas reorganizações do prisma semiótico "eu-outro-objeto-sentido do objeto para o self" (Zittoun \& Perret Clermont, 2009), assunto a ser discutido adiante. Nesse processo de desenvolvimento, novos campos de significação precisam ser criados na busca de estabilidade após o caos resultado da experiência inédita.

6.1.3.2 A emergência da posição "eu, vocacionada à vida religiosa consagrada"

A trajetória como servidora pública imaginada pela Cecília é interrompida com a reprovação na prova do MPU. Ela então se vê diante da necessidade de reprojetar o futuro e, consequentemente, criar novos sentidos, novo agir e sentir prospectivos. "Eu não desisti, mas assim, eu esfriei bastante, aí fiquei um tempo sem estudar, né? Foi mês assim, eu não peguei em livro, eu não peguei em nada, né? Também não tinha desistido, mas também não tinha aquele ânimo". Novas ambivalências são experimentadas pela jovem quando a posição de self "eu, servidora pública" perde centralidade na orientação e integração de um sentido de si. Isso causa a avaliação e reorganização de significados que compõem o complexo semiótico relacionado à vida profissional (Figura 1). Elementos como independência, responsabilidade, meta, presente, futuro, estudante, dedicação e concurso são ressignificados (ou abandonados) e passam a orientar de modo diferente processos dialógicos inter e intrapessoais.

A mudança no modo de se projetar num horizonte futuro permite que a Cecília experimente novas vivências e novas esferas de experiência. Novos mesocontextos encontram espaço na vida de Cecília, ao mesmo tempo que o cursinho, o órgão público, a preparação para ser servidora pública são descentralizados e já não se mostram "capazes" de dar suporte para um sentido de continuidade e integração do sistema de self. Isso nos leva a enfatizar a importância da trajetória imaginada, o senso de antecipação, no desenvolvimento presente. Um horizonte de possibilidades dialoga com 
experiências vividas no passado e no presente, resultando em modos de ser e de sentir do sujeito em relação a si e ao mundo.

Aí foi quando eu conheci um amigo, né? Ele é da igreja, né? E aí ele me falou de um grupo [...], Pastoral de Rua, e aí eu me interessei, achei bonito o trabalho que eles faziam. Fui fazer essa visita ao grupo, né? Assim, como quem não quer nada, e fui. Aí foi só isso, assim, foi o ponto de partida pra hoje eu estar aqui".

Eu pude conhecer assim mais o que era a miséria e a misericórdia, na verdade. [...] Eu via em cada visita, em cada irmão de rua eu via a misericórdia de Deus. O amor de Deus por cada um. E por nós também. Então, assim, foi um impacto muito grande... vê-los na rua e todos, quando a gente chegava, muito felizes cada um. E muitos falavam de Deus pra nós. Ao invés da gente falar, eles falavam muito pra gente. Então assim, eu via a misericórdia, o amor de Deus em cada um dos irmãos de rua. Esse foi o maior impacto pra mim. E também ver que tudo que a gente sofreu na família, né, de pobreza. E que não foi nada em relação ao que eles passavam, né? A gente ia assim debaixo das pontes e isso... isso pra mim bastava pra eu olhar minha vida com outros olhos. Ver que eu reclamava e murmurava demais e que alguém estava muito pior que eu. Então ali eu... eu também tive esse encontro com Deus. De saber que... que a misericórdia dele vai muito além, daquilo que eu pensava, esperava. De que a minha vida era um céu em relação a eles. E também porque os amigos que eu encontrei no grupo não eram amigos assim de bagunça, de sair. Eram pessoas que buscavam a Deus. Buscavam viver uma vida reta. Viviam uma retidão mesmo naquilo que é nossa fé católica. Então isso me chamou muita atenção. Eu queria sempre estar com eles. Por ver assim, eles buscando sempre a verdade, buscando ajudar uns aos outros. E o amor com que eles faziam toda obra. Era impressionante! Todos se reuniam para fazer a sopa. Todos iam pra rua pedir legumes, carne. Então assim, eram todos muito unidos. Eles se ajudavam muito. Isso sempre me chamou atenção. E o [Fulano] né, que era esse amigo, que foi religioso e casou. Foi ele que me mostrou, me falou assim, o que era vocação. [...] A gente começou a conversar sobre isso. Aí foi quando despertou mesmo, o chamado pra vocação... por estar buscando mais a Deus [grifo do pesquisador]. (primeira entrevista)

A reprovação no concurso público causa novas tensões e ambivalências, rompe com um futuro idealizado como possível. Cecília não quer desistir, mas já não consegue se dedicar aos estudos como sabe ser necessário para passar em um concurso público. E, nesse momento de ambivalência, permite-se novas ações, como visitar "assim, como quem não quer nada", um grupo de jovens com perspectivas, valores, ações e sentimentos distintos daqueles vivenciados no ambiente do cursinho e do órgão público. 
Cecília valoriza o encontro com o amigo e com o grupo de jovens, interpretando-o como uma ruptura no seu modo de pensar. A reprovação a deixou desanimada e o encontro com um outro significativo, primeiro o amigo e depois o grupo com seus valores, foi o que the possibilitou transformar um elemento cultural, a Pastoral de Rua, em um recurso simbólico ${ }^{5}$ capaz de sugerir novos modos de agir e sentir. E, com isso, uma integração e um sentido de continuidade do self. A jovem rompe com uma organização interna e externa: várias horas de estudo por dia, foco na prova, esperança de aprovação no concurso, desejo de vir a ser servidora pública, poder ajudar a família, começar uma faculdade. Uma reorganização interna e externa é exigida da Cecília.

Esse ciclo de novas produções de sentido representa para a jovem o início de mudanças significativas na sua vida: "foi o ponto de partida pra hoje eu estar aqui". Sendo o sentido pessoal resultado dinâmico das relações com outros, a partilha de significados na esfera de experiência Pastoral de Rua canaliza uma ressignificação da hierarquia de valores da Cecília.

Então eu comecei a ter outra visão, também, depois que eu entrei nesse grupo. Eu queria ajudar mais, queria servir a Deus. Que realmente foi a minha conversão, assim, onde eu falei: 'não, não é assim, a minha vida não está pautada a isso tudo, a bens materiais, a dinheiro'. Então, assim, eu realmente parei, parei de estudar, ainda fiz depois alguns concursos, aí eu parei de estudar pra realmente me dedicar a isso" [grifos do pesquisador]. (primeira entrevista)

Seu encontro com o grupo, simbolicamente traduzido como um "encontro com Deus", é fonte de novas tensões e ambivalências: ser servidora pública concursada ou "servir a Deus". É possível que, se Cecília tivesse conhecido o grupo antes de realizar a prova do concurso, o impacto dos valores e das crenças ali socializadas não seria o mesmo no seu sistema de self, até então orientado e integrado pela metaposição "eu, servidora pública". Numa perspectiva culturalista do desenvolvimento, mais importantes que os contextos em si, com seus limites e suas possibilidades, são as relações que a pessoa vivencia nessas esferas de experiência, bem como as relações que ela estabelecem, ou não, entre tais esferas.

Nesse momento da trajetória de vida da Cecília, o grupo de jovens torna-se uma importante esfera de experiência na reorganização do seu sistema de self: "foi a minha conversão". Um novo mesocontexto, com novas atividades, como rezar, ajudar o próximo, trabalhar em grupo para conseguir donativos e doá-los aos moradores de rua, partilhar sentimentos e crenças, passa a funcionar como moldura recorrente na ação e no sentir da Cecília. Sua experiência subjetiva fica canalizada e mediada por novos valores e novos sentidos.

\footnotetext{
5 O diálogo entre recursos simbólicos e complexos semióticos será aprofundado na discussão do caso
} Fátima. 
Figura 2. Complexo semiótico relacionado ao futuro vocacional: "bastava pra eu olhar minha vida com outros olhos"

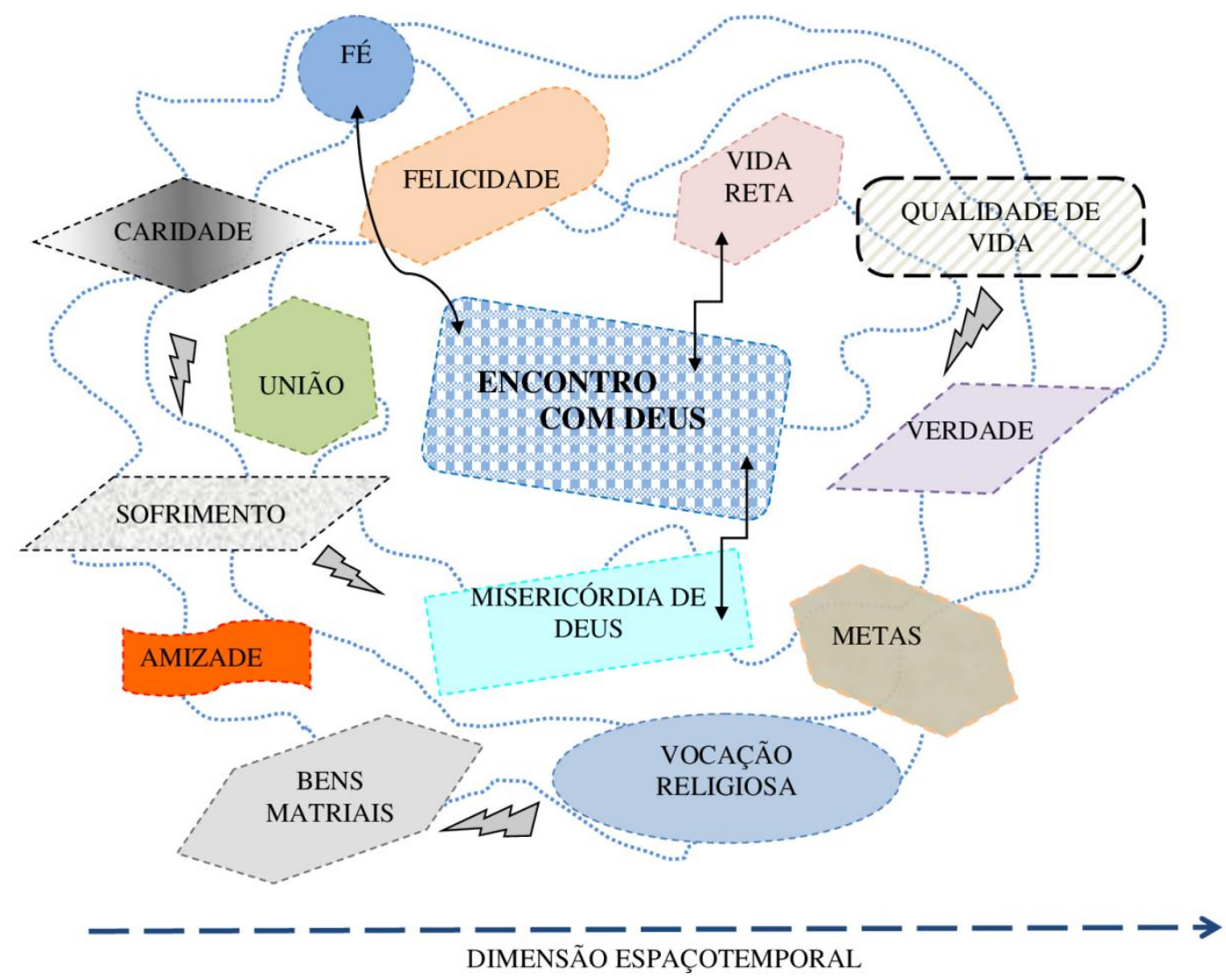

Fonte: Elaboração do pesquisador

Não podemos tomar essa transição como uma simples mudança de valores ou perspectivas. O espaço temporal entre o encontro com o grupo, o "fazer essa visita ao grupo, né, assim, como quem não quer nada", e o "parei de estudar pra realmente me dedicar a isso" deve ser compreendido como um tempo pessoal e uma vivência singular, com suas tensões e ambivalências, que dialogam com perspectivas da Cecília. Questionamentos como em que a vida deve se pautar ("a minha vida não está pautada a isso tudo, a bens materiais, a dinheiro"), ou o que fazer em relação ao futuro, parar ou continuar os estudos, são feitos por Cecília nesse momento de bifurcação na sua trajetória de desenvolvimento. Portanto, a transformação do elemento cultural, 
Pastoral de Rua, em recurso simbólico para a jovem é marcada por tensões e relações dialógicas entre vozes e entre esferas de experiência (grupo de jovens, cursinho, família, trabalho, igreja).

Um novo complexo semiótico emerge orientado pelo signo hipergeneralizado "encontro com Deus". O encontro com o outro significativo (amigo e grupo) é sintetizado e justificado no signo "encontro com Deus". Assim, esse complexo semiótico é composto por signos novos e ressignificados. Por exemplo, o signo "vocação à vida religiosa" é criado e externalizado com os amigos do grupo apenas "no segundo ano do grupo, foi quando a gente começou a conversar sobre isso". Esse é um signo que emerge de novas sínteses pessoais realizadas pela Cecília, um signo que irá se transformar numa posição central de um self possível "eu, futura religiosa".

Signos que compunham o complexo semiótico em torna da vida profissional são reavaliados e ressignificados - por exemplo, amizade, bens materiais, sofrimento, dinheiro, felicidade, pobreza, "bastava pra eu olhar minha vida com outros olhos". Cecília reavalia a própria história orientada pelo signo "encontro com Deus". Aqui é importante retomar como ela fala da sua família, na primeira entrevista:

eu cresci numa família de valores mesmo, né? Eu fui muito bem educada, naquilo que eu posso dizer que é educação. Nunca vi brigas dos meus pais, nem discussões, nada disso. Eles me criaram, eu e meu irmão, né, seguindo os princípios, valores, educação, formação espiritual, moral também, né? Ensinava muitas virtudes e assim, a gente foi sempre educado na fé. [...] Minha família foi sempre muito unida [grifos do pesquisador].

$\mathrm{Na}$ segunda entrevista, quando volto a questionar por que ela se identificou com as pessoas do grupo de jovens, tornando as relações estabelecidas naquele espaço importantes na sua história vocacional, ela diz:

minha mãe me passou isso, de amar o próximo. [...] Minha mãe era muito de ajudar todo mundo. [...] Se ela pudesse estar presente, não pudesse ajudar com dinheiro, então ela sempre foi de ajudar muito o próximo. [...] E o grupo de jovens era isso: ajudar o irmão de rua. [...] Foi pela caridade que fui pro grupo [grifos do pesquisador].

Ao relacionarmos essas duas falas sobre a experiência no grupo de jovens, somos remetidos à historicidade dos signos. Muitos significados presentes no complexo semiótico em torno dessa experiência parecem ter gênese na esfera familiar. Após o encontro com o grupo, Cecília diz ter começado a ver as coisas por outro ângulo: "então eu comecei a ter outra visão" antes mediado pela lente de futura servidora pública, seu olhar é agora mediado pela lente da fé católica. Essa transformação no modo de se relacionar com o mundo e de atribuir significado a ele traz consequências diretas na forma como a jovem se projeta num horizonte de futuro possível: "foi quando despertou mesmo, o chamado pra vocação... por estar buscando mais a Deus".

Os valores antes cultivados nas relações de Cecília com as esferas de experiência entram em tensão com os valores da nova esfera de experiência, o grupo de jovens. 
Toda a família, aquela rede de amigos que eu tinha, assim, ninguém me apoiou, assim, todo mundo jogou pedra. "Ah, você estudou tanto, vai jogar tudo pro alto." Então, assim, $a$ família também não gostou. Meu pai, então, foi um pé de guerra, porque ele queria que eu fizesse faculdade, me casasse. Ele também nunca aceitou a vocação [grifos do pesquisador]. (primeira entrevista)

Os valores que a Cecília começou a questionar, dinheiro e bens materiais, são extamente aqueles usados para justificar o fato de que "todo mundo jogou pedra". Portanto, os sentidos criados na esfera de experiência grupo de jovens não eram legitimados nas outras esferas de experiência, causando tensões dialógicas nas e entre essas esferas.

A decisão de parar de estudar para ser religiosa consagrada causa conflitos interpessoais, especialmente na esfera familiar, assim como na rede de amigos, pois "ninguém apoiou". Com a descentralização da preparação para o futuro profissional como eixo organizador das suas ações nas esferas de experiência, Cecília se vê diante de várias mudanças:

minha forma de relacionar com as pessoas... assim, foi perdendo... os amigos, a rede de amigos que tinha, porque era outro mundo, assim, estudavam, eram outra visão que tinham. [...] Fui arrumando outros amigos, né? Amigos da igreja, que meu pai também não aceitava. [...] Foi difícil em casa, porque... foi uma decepção pros meus pais, né? Eu não ia mais estudar [...] faculdade" [grifos do pesquisador]. (primeira entrevista)

Novamente a Cecília precisa criar signos e estratégias para protagonizar seu desenvolvimento. Apoia-se na esfera de desenvolvimento "grupo de jovens" e no signo "encontro com Deus" para legitimar suas novas perspectivas de trajetória. Traz para o complexo semiótico significados que atuam nas fronteiras causadoras de tensão. Para trabalhar a tensão causada pela constatação de que "ninguém me apoiou", cria signos do tipo "ser de opinião própria". Isso sugere a utilização desse sentido de si como um recurso simbólico, em diferentes esferas de experiência, orientando a criação de um sentido de continuidade e integração do self.

Assim, a emergência de novos complexos semióticos, fruto de tensões dialógicas fronteiriças, possibilita novas (pre)disposições internas e externas em diálogo com perspectivas futuras, delimitando novos horizontes de autoprojeção. Por sua vez, esses novos horizontes, ao serem integrados no sistema de self, passam a colaborar na coordenação de ações simbólicas do sujeito no presente, respondendo à necessidade do indivíduo de criar um sentido de continuidade de si, numa temporalidade cultural-pessoal.

6.1.3.3 A esfera de experiência instituição religiosa: "no dia da tomada de hábito foi uma provação tamanha" 
A celebração da tomada de hábito da Cecília se tornou um momento de ruptura numa temporalidade pessoal um tanto diferente do que a instituição intenciona ao integrar aquele rito na sua pedagogia de formação. Durante seu postulantado, a Cecília havia participado da tomada de hábito de duas outras jovens, o que contribuiu na criação de expectativas em relação a sua tomada de hábito, que ocorreu dias após a primeira entrevista. Porém, segundo a jovem, em vários aspectos sua celebração foi diferente, frustrando em muito suas expectativas.

É aquela expectativa, a tomada de hábito [...] não foi nada do que eu esperava [...]. Todo o rito foi diferente. [...] Eu estava tão triste, porque não é assim, não era daquele jeito que eu queria, que eu pensava, [...] eu chorei o tempo todo, [...] no dia da tomada de hábito foi uma provação tamanha. [...] O lugar que eu fiquei na missa, assim, não era como antes. Eu fiquei normal, como todas. [...] Eu vejo hoje que foi tudo para eu crescer, na vida espiritual. [...] Foi tudo muito providência de Deus, assim, pra minha alma, pra minha santificação. [...] No convento em si, a gente não faz o que a gente quer, né? É a vontade de Deus. A gente tem que estar aberto ao que ele mandar, à obediência. [...] Não era aquilo que eu queria, porque eu que queria [...]. Aqui não são as coisas exteriores que contam. É interiormente. [...] Eu tive exatamente o que eu pedi, Cláudio! Eu falava isso pra Jesus. Muito depois, né? Porque no dia eu não entendia nada! [...] E realmente só foi isso que ele me permitiu viver. [...] Foi uma oportunidade de me conhecer, de um autoconhecimento, de Jesus falar assim que é só isso que ele quer de mim. Só meu sim. [...] Porque a gente aqui dentro é uma constante purificação, assim, da vontade própria, mesmo. [...] Hoje eu vejo que eu estava muito assim nas coisas exteriores, [...] eu estava muito apoiada no que é o rito, no que é a celebração. Querer, assim, ser vista pelos outros na missa. [...] Então, assim, foi tirado tudo! Foi muita provação [grifos do pesquisador]. (segunda entrevista)

O noviciado é um tempo (institucional e pessoal) especialmente dedicado ao discernimento vocacional. A instituição proporciona reflexões e aprendizados específicos sobre o ser religioso consagrado. Esse momento é enfatizado como decisivo, visto que, ao final dele, o candidato professa publicamente os votos de pobreza, castidade e obediência, marca significativa da vida religiosa consagrada.

Na narrativa da jovem, é possível acompanhar uma ressignificação de si e da sua tomada de hábito, ancorado no signo hipergeneralizado "providência de Deus" (Figura 3). Esse novo signo campo (Valsiner, 2012) regula e orienta outros signos presentes num complexo semiótico, coordenando relações inter e intrapsicológicas. O signo hipergeneralizado, na dinâmica do complexo semiótico, funciona como signo heterorregulador, com significativa carga emocional, promovendo o desenvolvimento em determinada direção. Traz para o campo semiótico significados que corroboram esse tipo de promoção de desenvolvimento e interdita generalizações para outros 
grupos de experiência, evitando evocações "desnecessárias" de signos na interpretação da experiência.

Figura 3. Complexo semiótico orientador na ressignificação da tomada de hábito

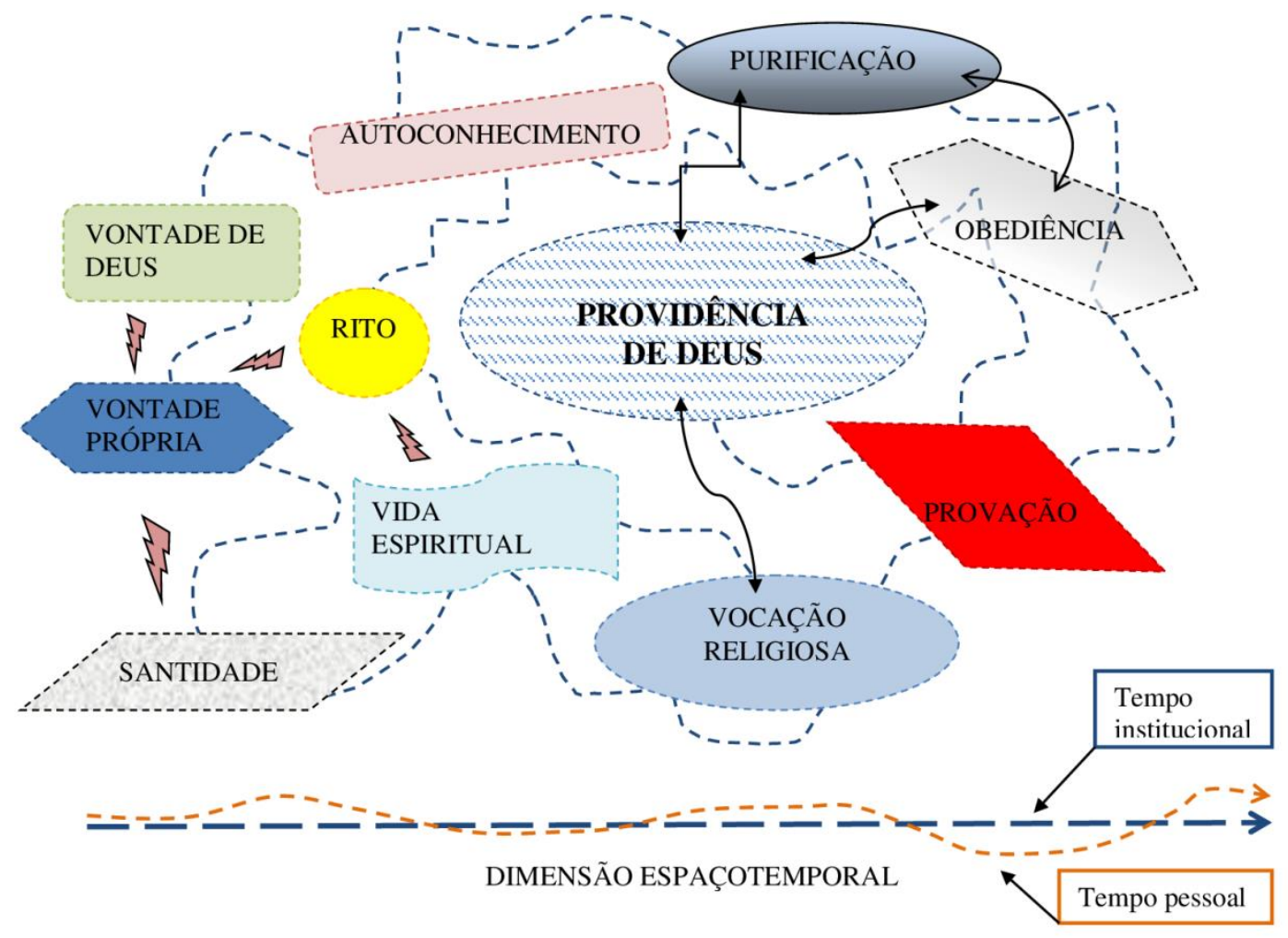

Fonte: Elaboração do pesquisador

O complexo semiótico orientado pelo signo "providência de Deus" é uma busca por conformação com valores institucionais, internalizados ou externalizados nos contextos formativos experienciados pela Cecília. Porém, é um fazer sentido de valores, de modos de existir e de sentir que são sugeridos e que dialogam com significados existentes no sistema de self da jovem. Esse dialogar nem sempre é harmonioso; muitas vezes, é realizado de forma a causar angústia, sentimento de contradição, dúvida e tensão. $\mathrm{O}$ autoquestionamento sobre o lugar dado às coisas materiais já havia povoado a mente da Cecília ao experimentar o contexto do grupo de jovens e da Pastoral de Rua, quando seu esforço por uma independência financeira e sua busca por assumir um cargo público foram colocados em avaliação.

O signo "providência de Deus" coordena relações e possibilita releituras do passado e projeções do self no futuro. Ao informar que afrontou a autoridade da madre quando manifestou insatisfação com a celebração da sua tomada de hábito, Cecília acrescenta: "eu não teria crescido mesmo não. Eu tinha ficado mais nas minhas vontades, no meu querer. [...] Depois eu agradeci 
muito a ela [a madre] de ter proporcionado tudo aquilo pra mim. [...] Me arrependi tanto, Cláudio, mas tanto, de ter falado o que falei pra ela". Cecília ressignifica o signo obediência, generalizando e aceitando que a obediência à madre é obediência a Deus, é estar aberta à vontade de Deus, um caminho para a purificação do querer próprio.

O estar aberta à vontade de Deus, assim como a busca por santidade e a constante purificação, são signos orientadores de relações inter e intrapsicológicas da Cecília no momento da segunda entrevista. Considerando que o sujeito possui complexos semióticos que se organizam em torno de signos hipergeneralizados, podemos afirmar que, em relação à narrativa da trajetória religiosa da Cecília, a busca por purificação e santidade assume importante papel prospectivo na orientação de futuro e na canalização de processos de desenvolvimento da jovem noviça. Assim, novas fronteiras semióticas são construídas em diálogo com suas perspectivas. E o signo "providência de Deus" funciona como uma ferramenta que ameniza tensões fronteiriças, "porque no dia eu não entendia nada! [...] Depois eu agradeci muito a ela de ter proporcionado tudo aquilo para mim".

6.1.3.4 A mudança de nome: "hoje que eu estou entendendo o meu nome"

Como já informado neste trabalho, entre os quatro estudos de caso, apenas a Cecília mudou de nome, assumindo um nome religioso. Este foi escolhido pela mestra, que assumiu a formação da Cecília desde o ingresso da jovem no postulantado. Naquela instituição, em geral, o nome é escolhido entre os nomes de santas reconhecidas pela Igreja Católica ou entre personagens bíblicos que desempenharam um papel significativo na história cristã. Portanto, o nome traz uma história vivida e uma missão que deve ser assumida pela formanda na concretização da sua vocação.

De seis a oito meses que eu estava no postulantado, a gente já foi rezando em intenção, ela me falou desse nome. Então, assim, eu não gostei muito não. Mas assim, o Espírito Santo falou nela. Então, ela que me acompanha espiritualmente, então eu, assim, aceitei [grifos do pesquisador]. (segunda entrevista)

O nome que a mestra sugeriu não agradou a Cecília. Ela explica que "não gostava por causa de uma ex-namorada do meu pai, que se chama [assim], infernizou a vida dele". Porém, naquele momento, não chegou a expressar sua insatisfação com o nome, "tem pouco tempo que eu falei pra minha mestra que eu não gostava do nome".

A mudança de nome, na primeira entrevista, aparentemente causava mais ansiedade na Cecília do que o rito da celebração da tomada de hábito. Isso pode estar ligado ao fato de ela já ter participado de outras tomadas de hábito antes da sua e, como ela mesma afirma, imaginar como 
seria a celebração. Porém, em relação ao nome, ao falar que era uma missão que assumiria, de viver o que o nome sugeria dentro da comunidade, tudo isso parecia que a empolgava. Podemos imaginar que assumir um novo nome, que traz uma missão a ser vivida, é uma mudança exigente para a Cecília.

Diferentemente dos outros três participantes, que mudavam de endereço a cada etapa de formação, a formação da Cecília foi realizada sempre no mesmo espaço. Mudando de casa, mudavam também de superior, pois cada casa tinha um superior local; mudavam, ainda, de mestre, de comunidade interna e externa. Portanto, tinham contato com outras pessoas, outras realidades, outras paróquias.

Como Cecília mora em um convento de vida contemplativa, não há esse deslocamento espacial, por isso a comunidade interna e a externa continuam praticamente as mesmas. Isso, inclusive, sugere que receber o hábito aparentemente tem pouco impacto na vida da formanda, no sentido de deslocamentos interpessoais. No postulantado, ela usava uma vestimenta que é chamada de uniforme, porém, da mesma cor do hábito oficial da congregação. Veremos que, para outros participantes (Francisco e Fátima), o hábito causa um reposicionamento identitário significativo, visto que, por serem de congregações de vida ativa, estão sempre em meio a leigos, pessoas não consagradas, e o uso do hábito se torna um diferencial significativo nas relações interpessoais, especialmente fora dos muros do convento.

Por tudo isso, e orientado pelos objetivos do estudo, considero que, em questões de reposicionamentos identitários, a mudança de nome é uma exigência desafiadora para Cecília. A partir do anúncio do seu nome religioso, ela seria observada e avaliada nas suas ações, considerando a missão que o nome sugeria.

Por questões éticas da pesquisa e o compromisso de manter o anonimato da participante, serei cauteloso ao falar da missão que o nome religioso da Cecília lhe exigia, considerando que tal missão reflete diretamente o nome e este seria facilmente identificado. Entretanto, focarei na transição semiótica realizada pela Cecília na fronteira de opostos: "eu não gostava do nome. Hoje eu já... eu escolheria esse nome". E, assim, irei analisar que signos foram fabricados e hipergeneralizados para auxiliar nessa transição.

[...] Na verdade eu não queria esse nome. Até porque eu não entendia. [...] Hoje que eu estou entendendo meu nome. [...] Eu sou chamada a ser verdadeira imagem de Cristo, [...] é muito difícil essa missão. [...] Eu, esteja ou não passando por dificuldades, por tribulações ou não, eu tenho que ser esse testemunho, [...] aconteça o que acontecer, assim, de dificuldade é ser esse testemunho. [...] E assim, na minha vida mesmo é viver isso. É ser verdadeira... ser verdadeira em tudo, assim, né? É... na comunidade, na vida pessoal, na minha vida espiritual [...] aliviar um pouco a humanidade, a comunidade, a madre, as irmãs. E naquilo que são minhas misérias também, [...] então eu que tenho que suportar, eu 
que tenho que ser essa presença de misericórdia também [grifos do pesquisador]. (segunda entrevista)

Cecília se sente desafiada pela missão que o nome exige. Para o objetivo da pesquisa, não é importante se a escolha do nome religioso da Cecília levou em consideração características da jovem. Mas interessa compreender que signos ela acessa no seu sistema de self para lidar com a tensão causada por um sentimento de rejeição ao nome. Tendo em mente esse processo, questiono a Cecília se seu nome religioso, para além da missão que ele traz, lhe remete a outros aspectos da sua vida, antes e depois de ingressar no convento:

antigamente eu levava... escondia as coisas do meu pai, da minha mãe. [...] Eu vivia uma inconstância lá fora, [...] oscilava muito na minha vida de oração, na caminhada de fé, mesmo. [...] De certa forma, era uma mentira que eu vivia na minha vida, [...] eu passava uma coisa e vivia outra. [...] E quando eu entrei no postulantado eu falava que eu não queria mais aquela vida que eu levava, de transmitir pras pessoas aquilo que eu não era e que a partir de hoje eu ia mudar. [...] Eu lembro que, quando eu entrei, eu falava que eu queria viver a verdade, mas não tinha dimensão disso [...]. A verdade de Cristo, a verdade do Evangelho. [...] Eu ia ser verdadeira em tudo e eu ia buscar viver mesmo essa verdade evangélica. O caminho de Jesus Cristo mesmo. [...] Eu não gosto de mentir nem brincando, [...] e toda vez que isso acontece eu me confesso, porque pesa muito, [...] tem que testemunhar isso, mas aqui dentro, não pros outros verem, mas diante de Jesus. [...] Lá fora eu não vivia isso. E hoje eu tenho que viver isso. E eu começo a entender isso hoje. O meu nome, o sentido do meu nome [grifos do pesquisador].

Apenas na segunda entrevista Cecília narra sentimentos e decisões que orientaram sua entrada no convento, no início do postulantado:

porque hoje, assim, eu estou tão mais segura, Cláudio, da minha vocação, do que Deus me chama e muito mais confiante em Deus assim, né, naquilo que ele quer pra mim, seja aqui dentro, seja lá fora. Então, assim, eu não tenho medo. Se amanhã ele quiser me mandar embora... Porque eu sei que é o melhor que ele quer.

Nesse sentido, o signo "verdade evangélica" assume espaço de coordenação em um complexo semiótico referente ao nome religioso. Como signo hipergeneralizado, "verdade evangélica" orienta modos de existir e de sentir em relação aos significados de obediência, de sacrifício, de missão, de misericórdia. "Mas é... se Deus tem me escolhido para falar com você, pra falar lá no curso [risos]. Eu sou muito assim, eu não posso falar não ao que ele me pede, né?" Mesmo se dizendo tímida, com dificuldades para se expressar, ela acredita que foi Deus que a escolheu para participar da pesquisa, bem como para falar da sua vocação no curso que frequentou. Pode estar aí uma explicação para ela iniciar o segundo momento de entrevista destacando que, caso eu queira, posso perguntar novamente sobre as questões que ela não quis comentar na primeira 
entrevista. Ela diz que acha que seria importante para a pesquisa, mas também podemos sugerir que ela estava se orientando pelo desejo de ser verdadeira em tudo - "hoje eu tenho que viver isso".

A Cecília enfatiza dois significados de seu nome religioso: primeiro, o de se ver "chamada a ser a verdadeira imagem de Cristo", que ela traduz como ser verdadeira em tudo que realiza, em tudo que vive; segundo, é ser auxílio, amparo e misericórdia em meio às irmãs com quem convive.

\subsection{Caso Fátima: a organização do sistema de self a partir do diálogo com recursos simbólicos}

\subsubsection{Momentos de entrevista e construção de informações}

Meu primeiro encontro com a Fátima se deu em 5 de setembro de 2014, no convento onde a jovem participava de um encontro de jovens noviços em formação para a vida religiosa consagrada (Novinter ${ }^{6}$ ), na cidade de Goiânia. Na oportunidade, expliquei os objetivos do estudo e solicitei a assinatura do TCLE. Falei sobre a metodologia do estudo e os possíveis encontros que teríamos pela frente. Considerando a disponibilidade da jovem, não foi possível que ela respondesse ao Guia de Evocação de Narrativas Escritas. E assim, naquele mesmo dia, realizamos a primeira entrevista presencial.

$\mathrm{Na}$ época, ela estava com 19 anos, e aquele era o seu terceiro ano na formação religiosa e o primeiro ano do seu noviciado. Fátima ingressou na instituição aos 16 anos, em 2012, ano em que cursou o terceiro ano do ensino médio já morando no convento. Conversamos sobre a história da sua vocação para a vida religiosa, bem como sobre sua família, infância, adolescência, estudos, trabalho, o contexto formativo da instituição religiosa e suas perspectivas em relação ao futuro.

Em fevereiro de 2015, estando a Fátima no segundo ano do seu noviciado, continuamos em contato por whatsapp e telefone. Não sendo possível para ela participar de conversas via Skype, sugeri que me escrevesse um e-mail informando sobre temas como o final do primeiro ano de noviciado, o início do segundo ano de noviciado, o contexto da nova casa de formação, as pastorais de que estava participando, as perspectivas e os planejamentos para a profissão dos votos

\footnotetext{
6 Encontro direcionado apenas aos jovens, de ambos os sexos, que estão na etapa de formação noviciado. $\mathrm{O}$ encontro é preparado por padres e freiras, já professos solenes, e, em geral, conta com palestras, momentos de oração coletiva e individual, trocas de experiências e confraternização.
} 
religiosos, que ocorreria ao final daquele ano. Assim ela fez, possibilitando que eu acompanhasse, mesmo a distância, os acontecimentos na sua vida.

A segunda entrevista presencial com a Fátima foi realizada em 9 de fevereiro de 2016, nas dependências de um convento em Brasília, onde estava hospedada para participar de um encontro para jovens religiosos de diferentes congregações (roteiro utilizado em anexo VII). Aquela entrevista realizou-se dois meses após o término do segundo ano de noviciado da Fátima, quando professara publicamente os votos religiosos. Na oportunidade, conversamos sobre a experiência vivida pela jovem no segundo ano de noviciado; o significado dos votos religiosos (pobreza, castidade e obediência); o sentido de ser agora uma religiosa consagrada, reconhecida pela igreja e pela comunidade; a experiência de ser a primeira e única freira da sua congregação a usar hábito religioso; e suas perspectivas. Assim como ocorreu com os participantes Francisco e Vicente, mediante redes sociais, e-mail e whatsapp, pude manter contato com a Fátima no período entre as entrevistas presenciais e, também, depois destas.

\subsubsection{Caracterização do caso}

A Fátima é a filha caçula de um grupo de seis irmãos. Seus pais se separaram quando ela estava com nove meses de vida, e desde então ela morou com a mãe e os irmãos, tendo sempre por perto a presença do pai. Segundo a jovem, sua mãe sempre foi muito participativa na igreja, desempenhando ali várias atividades, para as quais geralmente levava a garota. Aos 12 anos, a Fátima se tornou coroinha ${ }^{7}$, passando a ter novas responsabilidades na igreja e conhecendo melhor os ritos litúrgicos. Ela ressalta que gostava de estar no ambiente da igreja e de participar das atividades ali desenvolvidas.

Segundo a Fátima, seu interesse pela vida religiosa consagrada se deu aos 14 anos, quando chegaram em sua comunidade duas freiras usando hábito religioso. Até então, as freiras que a garota conhecia não usavam vestes próprias. Ela ressalta ter percebido naquelas freiras de hábito uma alegria diferente ao desempenharem as atividades na igreja. A partir de então, buscou compreender, especialmente junto à sua mãe, o que era vida religiosa consagrada, bem como o que a freira podia fazer no ambiente da igreja.

7 Pessoa, em geral criança ou adolescente, que auxilia o padre na celebração da missa. O coroinha (ou acólito) tem vestes próprias e sua função o coloca em destaque no altar, ao lado do celebrante. Suas tarefas podem ir desde a correta preparação do altar ao correto manuseamento do missal romano e - em celebrações mais solenes - do turíbulo, o transporte da Cruz, das velas e do Evangelho ou todas as demais tarefas que "aparecem ocasionalmente" a depender do tempo litúrgico. 
Por ser muito atuante na igreja, a garota diz ter sido convidada para participar dos encontros vocacionais promovidos pelas irmãs que usavam hábito religioso. Sentiu-se motivada pelas reflexões que vivenciava naqueles encontros: "aquele negócio chamava atenção. Aquele monte de perguntas: 'O que que você quer? Pra que que Deus te chama?' Perguntas assim, que eram... se referiam à vida da pessoa: 'o que que eu quero ser'”. Foi quando the ocorreu a possibilidade de ser freira.

Meses mais tarde, algumas garotas que também participavam dos encontros vocacionais ingressaram no convento. E assim, através de cartas, a Fátima pôde conhecer melhor o modo de formação de uma freira, bem como a rotina no convento. Porém, cessou o contato com aquelas freiras ao ser informada de que só poderia ingressar naquele convento quando completasse 18 anos e terminasse o ensino médio. Na época, ela estava com 15 anos e cursava o segundo ano do ensino médio.

Alguns meses depois, Fátima recebeu uma carta de uma freira de outra congregação religiosa, que ficou sabendo do seu interesse pela vida religiosa através de um membro da comunidade local. Diz ter se sentido cativada pela maneira como a carta lhe foi direcionada, pelo carinho e atenção que expressava. Passou a se corresponder por carta com a freira, falando sobre sua vida e seus objetivos e conhecendo as características daquela congregação — onde o hábito religioso não era usado por nenhuma freira. Dois meses depois de iniciarem essa aproximação por carta, no aniversário de 16 anos da Fátima, a freira foi visitá-la. Nessa oportunidade, a Fátima tirou várias dúvidas sobre a vida religiosa, compreendendo melhor como era a formação e o cotidiano naquela congregação.

No ano seguinte, 2012, ainda com 16 anos, a Fátima ingressou no convento como aspirante e, morando ali, cursou o terceiro ano do ensino médio. Em 2013, mudou-se para outra casa de formação, onde fez o seu postulantado. E em 2014, morando em uma terceira cidade, iniciou o primeiro ano do seu noviciado (ano canônico), quando se deu sua primeira participação nesta pesquisa. No ano seguinte, ela vivenciaria a segunda parte do noviciado (ano apostólico) ${ }^{8}$, ao final do qual celebraria os votos de pobreza, castidade e obediência, passando a ser reconhecida pela igreja como freira consagrada.

Na segunda entrevista, em 2016, a Fátima atendia pelo título de irmã e havia professado os votos religiosos dois meses antes. Vestia um hábito religioso, que foi pensado especialmente para ela, visto que, naquela congregação, nenhuma freira havia decidido usar hábito até então.

$8 \quad$ Na instituição da qual a Fátima faz parte, assim como na formação da Cecília, o noviciado dura dois anos. O primeiro ano é chamado ano canônico e é um período mais recluso, com poucas atividades externas. O foco, no ano canônico do noviciado, são as orações e os estudos sobre a história e o carisma da congregação ou da ordem. Já no segundo ano de noviciado, chamado ano apostólico, para além das orações e dos estudos, a candidata tem uma participação mais expressiva em atividades externas à casa de formação, nas pastorais da igreja. 


\subsubsection{Movimentos semióticos e tensões dialógicas na trajetória de vida da Fátima}

Ao construir narrativas sobre os temas solicitados em pesquisa, os participantes utilizam-se de processos linguísticos e cognitivos moldados culturalmente. A experiência perceptiva e o modo de organizar os eventos bem como de sequenciar a memória e selecionar os fatos são estruturados narrativamente em diálogo com esses processos linguísticos e cognitivos aprendidos culturalmente (Bruner, 1987). Da mesma forma, a pessoa constrói narrativas de si a partir de narrativas socialmente sugeridas, e ambas assumem função organizadora no sistema de self.

Ao discutir transições de desenvolvimento e processos dialógicos no sistema de self da Fátima, à luz da sua experiência religiosa, alguns complexos semióticos foram analisados em diálogo com recursos simbólicos (Zittoun, 2006a, 2007a) que se mostraram importantes na orientação de um sentido de continuidade de si nas narrativas da jovem. Os recursos simbólicos aqui discutidos foram aqueles que mais ganharam destaque nas narrativas da jovem. Eles também nos ajudam a pensar o papel constituinte e regulador de signos da tradição católica na canalização de sentidos na experiência religiosa.

Segundo Zittoun (2006a, 2007a), os recursos simbólicos, sempre disponíveis na cultura coletiva (elementos e objetos como livros, músicas, filmes, sentidos e significados em geral), são utilizados nos momentos de transição de desenvolvimento, auxiliando a pessoa na manutenção de um sentido de continuidade de si. Nesse processo, os elementos culturais integram o sistema de self da pessoa, orientando e direcionando trajetórias de desenvolvimento, mantendo alguns posicionamentos sociais e possibilitando a emergência de outros, emocionalmente marcados.

Por estarem presentes na cultura, organizada coletivamente, os recursos simbólicos são reforçados com certo grau de afetividade (ora mais, ora menos) nas interações sociais, sugerindo modos de ser e de sentir, bem como de interpretar a si e o mundo. O sujeito internaliza e externaliza sentidos e significados mediante interações dentro do complexo sistema cultural. E os recursos simbólicos podem ser utilizados pela pessoa como um suporte para lidar com o ineditismo da experiência humana e com futuros imaginados.

Mediante recursos simbólicos e processos linguísticos e cognitivos aprendidos no contexto institucional, a Fátima atribui significado a situações de ruptura e descontinuidade, no intuito de manter uma continuidade no seu sistema de self. Esse processo se mostra fundamental nas transições de desenvolvimento da jovem, pois lhe permite ampliar sua "arquitetura do self" (Zittoun, 2006a, p. 53), ao mesmo tempo que experiencia um espaço-tempo diferente em relação à esfera cotidiana compartilhada. 
No estudo de caso Fátima, foram focados quatro recursos simbólicos que, utilizados pela jovem na organização de suas narrativas, sustentam (re)configurações de experiências vividas e imaginadas, orientando e direcionando transições de desenvolvimento na sua trajetória de vida. De modo singular, esses recursos simbólicos oferecem possibilidades e limites pessoais e institucionais na emergência de novos posicionamentos sociais e modos de ser e de sentir na construção de significados de si e do mundo. São eles: 1. vocação religiosa, 2. formação para a vida consagrada, 3. hábito religioso e 4. consagração religiosa.

6.2.3.1 A emergência da vocação religiosa: "eu não identificava que isso seria ser freira"

Fátima esclarece, no início da primeira entrevista, que sua história de vocação não tem nada de extraordinário nem se iguala à história de nenhum santo ou santa. A jovem sugere que o gosto que sentia em participar, em estar presente nos ambientes onde havia padres e freiras, onde tinha "uma vida assim diferente", é resultado de uma proximidade que teve com a igreja desde criança, mediada pela mãe.

Minha história de vocação não tem nenhuma novidade, assim... porque tem gente que [...] diz: 'ah, eu era do mundo e aconteceu uma coisa, um fato, e eu me converti, senti o chamado pra ser freira, pra ser padre [...] da noite pro dia'. A minha não. Eu cresci na Igreja Católica, mas assim... algo deve ter me atraído ali naquele ambiente, porque... quantas pessoas cresceram na Igreja Católica e depois se desviaram, [...] eu cresci ali, junto com minha mãe. [...] Eu estava sempre com ela, em ambiente de igreja: curso, tudo que diz respeito a igreja eu sempre estava também. E esse negócio foi alimentando, [...] gosto de participar das coisas com a mãe. Mesmo que seja coisa de adulto, mesmo que seja coisa que eu não entenda, mas eu gosto de estar lá, naquele ambiente. Ambiente que tem padre, ambiente que tem freira, ambiente que... tem uma vida assim diferente, né? Eu gostava [grifos do pesquisador]. (primeira entrevista)

Desde a separação do marido, a mãe de Fátima se tornou mais participativa na igreja, precisando dividir o tempo entre a atuação na igreja e as obrigações da vida doméstica. Por ser a filha caçula, a Fátima acompanhava a mãe, inclusive nas atividades na igreja. Ao longo do tempo, aquelas repetidas experiências foram interpretadas como positivas pela garota. Ela se sentia bem naquele ambiente e queria voltar sempre.

Aos 12 anos, a Fátima assumiu o cargo de coroinha na comunidade, fato que ela classifica como importante na sua escolha vocacional porque, desde então, passou a conhecer de modo mais aprofundado assuntos religiosos e "isso foi crescendo em mim, cada vez eu gostava mais, cada 
vez... quanto mais fazia, mais queria fazer". A atuação como coroinha na igreja reserva um espaço físico e semiótico para a Fátima que a diferencia de suas amigas e amigos. Por mais que dissesse ser uma garota como outra qualquer, segundo a própria Fátima, ela se achava diferente e atribuía essa singularidade em parte à educação que recebera de sua mãe e em parte ao fato de ser coroinha e gostar muito de participar das atividades da igreja. Mais tarde, tal singularidade no sentir e no agir em relação ao ambiente religioso foi compreendida como vocação para a vida religiosa consagrada:

quando a gente é coroinha, tem um conhecimento a mais do que todas as crianças e até adultos que estão ali. [...] Tinha minha vida normal de escola, da família, amiguinhos, não sei o quê, essas coisas... da infância. [...] A diferença era isso: de gostar muito de ir pra igreja. Porque minhas colegas não gostavam tanto como eu. E quando fui crescendo, esse negócio de coroinha, isso aí marca na escola. Quando a gente é coroinha, né? De uma sala, de uma turma toda de 30 alunos, uma pessoa só é coroinha, [...] naturalmente a gente muda o comportamento. Eu tinha realmente um comportamento diferente dentro da sala pelo fato de eu ser coroinha e ser de toda de dentro da igreja.

Nos trechos de entrevista citados acima, a jovem busca integrar-se às esferas de experiência de que participa. Ser coroinha é uma atividade na igreja que precede a existência da Fátima, portanto, é um elemento cultural, carregado de sentidos socialmente construídos. Ao assumir a responsabilidade de coroinha na igreja, a garota sente pressões internas e externas em função de uma integração entre sentidos pessoais e sentidos socioinstitucionais. Ser coroinha e ser "toda de dentro da igreja" oferece limites e possibilidades de ação — por exemplo, "um conhecimento a mais do que todas as crianças e até adultos”. Portanto, o elemento cultural passa a funcionar como recurso simbólico orientador de um sentido de continuidade de si da garota.

Até então, este sentir-se bem no ambiente da igreja, querer estar ali por mais tempo, não era compreendido como vocação para a vida religiosa, portanto não era canalizado pelo signo vocação religiosa. Porém, o modo de vivenciar as atividades naquele contexto causava tensões com outras esferas de experiência. Muitas vezes, a Fátima preferia estar ali a cumprir com outras obrigações em casa e na escola, por exemplo. Ela percebia que a mãe vivia a mesma tensão, especialmente entre as responsabilidades e exigências do contexto familiar e as atividades desempenhadas na igreja. E assim a Fátima vai identificar no modo de vida das freiras uma possibilidade de resolver a tensão entre vida matrimonial e atividades religiosas:

comecei a perguntar pra mãe: ‘mãe, que é isso?’ Freira, né? [...] O que é uma freira? ‘Ah, são pessoas que deixam a família, que escolhem seguir Jesus radicalmente'. Ah, essa palavra 'radicalmente'... que é muito forte pra gente, nosso ambiente todo... seguimento radical de Jesus, né? Seguir ele, a gente pode seguir em todo lugar que a gente estiver. No casamento, na vida leiga, em qualquer lugar. Mas elas escolheram radicalmente. Falei: 
'ah, interessante!' Aí eu comecei a me identificar. Falei: 'olha, eu sempre quis o algo mais dentro disso aqui que eu gosto. Então, talvez seja isso daí. [...] E eu sei que, se eu casar... de pequena eu já pensava nisso, eu sei que se eu casar, eu não vou dar conta de fazer muito. Porque eu vou ter minha preocupação com marido, com os filhos, com a casa, como toda dona de casa tem. E se eu não casar aí eu tenho mais chance, né, de me dedicar àquilo [grifos do pesquisador].

A Fátima, ao sentir-se atraída pelo hábito religioso das freiras, como será visto adiante, interessou-se por conhecer o trabalho de uma freira na igreja. Tal conhecimento a levou a estabelecer relações dialógicas entre sua satisfação em estar no ambiente da igreja e os limites e as possibilidades que uma dona de casa, inclusive sua mãe, tem para ocupar os dois espaços de ação. A garota constrói um sentido de si mediado pelas experiências vividas nas esferas de experiência familiar e religiosa; cria e transforma significados, integrando no seu sistema de self futuros imaginados que lhe exigem ações no presente.

Aprendera até então que ser cristã, seguir os ensinamentos de Jesus Cristo e da igreja, era possível "no casamento, na vida leiga, em qualquer lugar". E, observando seu contexto sociocultural, compreendia que, se casasse, não iria "dar conta de fazer muito". Por isso, começou a vislumbrar a possibilidade de ser freira, uma vez que "sempre quis o algo mais dentro disso aqui que eu gosto. Então, talvez seja isso dá'”. Portanto, um interesse pela vida das freiras, que começou por um encantamento pelo hábito religioso que elas usavam, num movimento semiótico, é direcionado ao elemento cultural vocação para a vida religiosa consagrada.

Com tais motivações, a Fátima começa a participar de encontros vocacionais. Uma nova esfera de experiência abre espaços de ação no presente em busca de um futuro imaginado: "eu comecei a participar dos encontros vocacionais... aquele negócio chamava atenção! Aquele monte de perguntas: 'O que você quer? Pra que que Deus te chama?' Perguntas assim, que eram... se referiam à vida da pessoa". Nessa nova esfera de experiência, a garota descobre o significado institucional de vocação religiosa.

O elemento cultural vocação religiosa, como recurso simbólico, se mostra fundamental na transição de desenvolvimento dos participantes deste estudo. Ele garante um sentido de continuidade mediante a ressignificação de experiências passadas e oferece novos sentidos que passam a funcionar como prótese no lidar com experiências inéditas.

Nas experiências da Fátima na família, na igreja e na escola, atividades repetitivas em relação aos valores religiosos são constantemente reforçadas. Reflexões colocadas pela garota a si mesma, assim como questionamentos com os quais ela se depara nos encontros vocacionais, por exemplo, entram em diálogo com um complexo semiótico que é coordenado pelo signo institucionalmente sugerido: vocação religiosa. 
Tinha uma coisa assim, uma inquietação, mas eu não sabia o que que era, que queria ser freira. Não falava pra ninguém, nem pra mãe. Mas eu dizia assim: 'ah, é tão bom ficar aqui. Eu não quero só vir pra cá... venho aqui igual todo mundo, venho pra missa... vem, entra na igreja, participa da missa, sai, tchau, acabou. Não, eu quero mais, eu gosto disso daqui, mas eu quero mais disso daqui'. Mas eu não identificava que isso seria ser freira. Nem tinha noção do que que era freira. Assim, tinha visto, devia ter visto, né? Mas não tinha nenhum aprofundamento, nem nada, nem um conhecimento de, de freira [grifos do pesquisador]. (primeira entrevista)

O trecho acima sugere uma trajetória de movimentação semiótica que parte de um sentimento de inquietação, nebuloso, fisiológico, de satisfação, até a criação de significados em harmonia com sugestões socioinstitucionais referentes ao elemento cultural vocação para a vida religiosa. Inicialmente a garota sentia satisfação em estar na igreja e participar daquele ambiente, e mais tarde interpreta esses sentimentos como vocação para ser freira. Considerando sugestões sociais dos contextos que vivenciava, a Fátima compreende sentimentos nebulosos em relação ao ambiente da igreja numa I-position "eu, vocacionada à vida religiosa consagrada". A partir do recurso simbólico vocação religiosa, novos significados são construídos em relação às experiências no passado, assim como novas perspectivas imaginadas povoam o sistema de self da garota.

Para o orientador espiritual eu falei: padre, eu sempre tive certeza da minha vocação, desde o começo. Talvez as dúvidas que veio foi do lugar "será que é nessa congregação, será que é nisso daqui que eu quero ficar, nesta obra?" As dúvidas foram por causa disso, mas assim, da vida religiosa, assim, que eu queria ser religiosa, a dúvida primeira foi só aquela lá de ficar ou não na casa, né? A que... do primeiro dia, a primeira saída de casa. Mas o resto sempre foi assim, muito claro, muito nítido. Não, eu... eu acho que tenho vocação pra isso. Se eu cheguei até aqui! [grifos do pesquisador. (primeira entrevista)

Em uma conversa com seu orientador espiritual, ao falar das dificuldades que estava sentindo de adaptação ao noviciado (no terceiro ano morando no convento), a jovem afirma sempre ter tido certeza da sua vocação para a vida religiosa consagrada. Sente que as dúvidas foram em relação à escolha da congregação e à saída do aconchego familiar. Mediante uma ressignificação da experiência vivida, a jovem sugere que todas as inquietações, os sentimentos de satisfação em estar no ambiente da igreja, em participar das atividades religiosas com a mãe, mesmo sendo coisas de gente grande, mesmo sem que ela entendesse direito o que era, tudo isso era devido ao fato de sempre ter sido vocacionada à vida religiosa consagrada. Ancorada nos limites e nas possibilidades oferecidos pelo elemento cultural vocação, a jovem ressignifica experiências vividas concluindo que "sempre tive certeza da minha vocação, desde o começo", ao mesmo tempo que lida com tensões em relação ao futuro: "acho que tenho vocação pra isso. Se eu cheguei até aqui!" 
Por meio de processos linguísticos e cognitivos emocionalmente orientados e institucionalmente sugeridos, a jovem constrói uma narrativa de si a partir de narrativas socialmente ofertadas, num processo de autorregulação do sistema de self:

o fundamento de tudo é a pessoa de Jesus. Não são as atividades, não são pessoas... a irmã, por causa da irmã [Fulana], por causa da minha mãe, não foi influência nenhuma, nunca da minha mãe. Então o fundamento é... a base da gente é muito mais profundo do que as pessoas possam entender. Talvez todo mundo não vai entender, porque a gente leva uma vida de oração intensa, a intimidade com Deus, é crescendo nisso que a gente vai... acho que confirmando a vocação. Não sei se é esse o termo, mas assim, vou clareando minha vocação [grifos do pesquisador]. (primeira entrevista)

Como signo regulador, a vocação possibilita (re)configurações de si e a Fátima parece rejeitar situações e pessoas que estiveram na emergência do seu sentir-se vocacionada à vida religiosa. Ao ser transformado em um recurso simbólico, o elemento cultural vocação religiosa, como signo hipergeneralizado, funciona como campo semiótico orientador de modos de ser e de sentir da jovem Fátima. Ao mesmo tempo, tais movimentos semióticos exigem um ajustamento entre a narrativa pessoal da jovem e uma narrativa institucional, ambas ancoradas naquele elemento cultural.

Uma irmã formadora dizia que a gente mede se a gente tem ou não vocação, que esse termo também não existe muito, é no dia a dia, somando os dias que mais me ajudam, não os dias mais alegres, mais positivos... sei lá, porque tem dias que a gente tem dificuldade e marcam, né? Marcam pra gente crescer. E é no dia a dia! O termômetro é no dia a dia [grifos do pesquisador]. (primeira entrevista)

Assim, o recurso simbólico vocação religiosa passa a ser usado como suporte pela jovem no processo de transição de desenvolvimento, por exemplo, em ajustamentos à pedagogia formativa do convento e na criação de um sentido pessoal para o conceito sociocultural consagração religiosa, como veremos adiante. A seguir, discuto um segundo complexo semiótico presente na trajetória de desenvolvimento da Fátima, em diálogo com o recurso simbólico formação para a vida religiosa consagrada. A formação de uma freira, ou de um padre, é vista neste trabalho como um elemento cultural institucionalmente sugerido e pessoalmente interpretado como recurso simbólico.

6.2.3.2 A formação para a vida religiosa consagrada: "estava acostumada com Marta, de correr, correr e fazer" 
Ao ser entrevistada pela primeira vez, a Fátima estava prestes a terminar seu primeiro ano de noviciado, o ano canônico. Por várias vezes durante aquela entrevista, ela relatou dificuldades que estava sentindo com as exigências daquele primeiro ano de noviciado. Acostumada a ser muito atuante na igreja, antes de ingressar no convento e nos dois primeiros anos de formação, aspirantado e postulantado, ela agora achava difícil focar apenas a oração e os estudos. Sendo o noviciado uma etapa de formação dedicada à oração e ao estudo, o trabalho pastoral não é prioridade, especialmente no ano canônico.

O primeiro ano é ano canônico que chama. E é um ano fechado, fechado, fechadíssimo. Durante os dois anos a gente não vai em casa. [...] O ano canônico é o ano em que a gente não pode assumir nada fora, nenhuma pastoral. Não pode ajudar na igreja. Assim, é um momento intenso de oração e estudo. É o ano canônico do noviciado. De toda a formação, é esse ano o que... forma a pessoa, digamos assim. Tudo que não aconteceu nos outros anos vai ser acontecido agora. Um ano de viver em oração. Tanto que eu gostava de rezar... e assim... não foi assim que eu fui acostumada desde quando eu entrei na congregação! Desde que eu entrei, eu fui acostumada a ajudar, a fazer as coisas. Rezar sim, rezar é prioridade, é a primeira coisa que a gente faz no começo do dia. Primeira e a última, e tem as orações durante o dia. Mas tinha aquela atividade, sempre teve alguma coisa pra eu tá fazendo! O noviciado não, ano canônico, que a gente está. Ano que vem chama ano apostólico, que já é um ano diferente. [...] Só reza e estuda, só reza e estuda, só reza e estuda. Não que seja ruim, não, mas eu não fui acostumada com isso, não. Não estava acostumada. Eu conto as horas pra sair, porque depois dos votos, aí a gente vai assumir missão, Deus sabe... Deus é que sabe pra onde que a gente vai. Mas eu não vou ficar nunca mais parada! É esse ano. De oração e estudo, de oração e estudo [grifos do pesquisador]. (primeira entrevista)

O noviciado é um momento significativo na formação dos jovens religiosos, vivenciado pelos quatro participantes no período deste estudo. Ao final dessa etapa, os candidatos professam publicamente os votos religiosos de pobreza, castidade e obediência. Nesse sentido, cada congregação se utiliza de uma pedagogia, sugerindo reflexões, atitudes e modos de ser e de sentir aos candidatos. Por sua vez, estes buscam adequar-se às demandas institucionais, atribuindo significado aos sentimentos com base em sugestões encontradas naquele contexto em diálogo com a própria trajetória de vida.

$\mathrm{Na}$ etapa de formação do noviciado, a instituição restringe a participação presencial dos candidatos nas outras esferas de experiência. $\mathrm{O}$ candidato não visita a família, os estudos são realizados apenas no âmbito da casa de formação, e a participação nas pastorais é quase inexistente. Há uma pressão, por parte da instituição, para que o candidato reflita sobre a própria vocação e sobre as especificidades do ser religioso naquela instituição. Por isso, muitas vezes, surgem tensões 
decorrentes da necessidade de ajustamento entre duas instâncias: de um lado, uma pressão por parte da tradição, daquilo que é valor institucional; de outro, uma resistência pessoal do sujeito. Trata-se de um misto de ajustamento e resistência em diálogo com experiências vividas e futuros imaginados.

Durante o ano canônico do noviciado, a Fátima vive uma tensão entre o que a instituição pede, intensa oração e estudo na vivência da vocação, e aquilo a que ela estava acostumada na vivência da sua vocação, inclusive o que lhe dava satisfação: participar ativamente em pastorais da igreja. Considerando a própria experiência, a jovem avaliava o seu primeiro ano de noviciado de modo bem diferente daquele que, em geral, outros religiosos, e a própria instituição, sugeriam:

aí no começo do ano foi muito difícil, muito difícil mesmo! E todo mundo dizia: "o noviciado é muito bom. O noviciado é a melhor parte da... da preparação. E de toda a vida religiosa". [...] O momento que mais marcou foi o noviciado. E aí eu estava criando aquela expectativa. Aí quando cheguei eu falei: "não, não gostei, não! Como é que esse povo gostou? O que que viram aqui pra gostar que eu não estou gostando? Mas eu sei que foi muito difícil! Agora nós estamos em setembro. Agora eu estou bem mais tranquila. Agora eu estou assim me atentando que está acabando e talvez eu não aproveitei como deveria ter sido mais aproveitado" [grifos do pesquisador]. (primeira entrevista)

$\mathrm{O}$ ano canônico do noviciado, até o momento da primeira entrevista, havia frustrado as expectativas da jovem Fátima. E ela, numa resistência ao presente, cria estratégias para lidar com aquela tensão, recorrendo a um horizonte de possíveis ações para fazer sentido de continuidade de si: "ano que vem chama ano apostólico, que já é um ano diferente. [...] Eu conto as horas pra sair. [...] Deus é que sabe pra onde que a gente vai. Mas eu não vou ficar nunca mais parada!" Resistindo às experiências dos outros, bem como às sugestões institucionais, a jovem recorre à integração do futuro no presente para lidar com tensões causadas por situações inesperadas e encontrar, assim, modos de ser e sentir.

Diante dessas tensões, a instituição sugere significados para os sentimentos vivenciados. Há um resultado singular desse encontro entre pessoal e institucional. Mediado por sugestões socioinstitucionais, o sujeito se posiciona numa autorregulação do sistema de self: "a gente é acompanhada por um padre, né? Orientador espiritual. E aí ele me conforta muito quando ele diz assim: "não, o noviciado é a parte mais difícil, é a melhor, mas é a mais difícil. Porque é o lugar onde tu vai ver: eu quero ou não quero". Assim, em diálogo com experiências vividas e futuros imaginados, a Fátima resiste a alguns sentidos institucionais e adere a outros.

A experiência no noviciado também é tema da nossa segunda entrevista. Nessa época, a jovem já é professa simples e, portanto, já terminou os dois anos de noviciado. Contudo, apresenta novas leituras da etapa de formação noviciado: 
Porque até o postulantado a gente está envolvida nas coisas, né? Aí quando chega no noviciado é aquele momento de olhar pra dentro, de parar mesmo, de colocar os pés no chão. De fazer o papel de Maria, né? Maria parada, sentada aos pés do Senhor. E a gente estava acostumada com Marta, de correr, correr e fazer, mas foi difícil o começo, mas depois até que a gente vai indo, entrando no clima, né? Mas demorou a passar o ano. Acabou, graças a Deus, tudo passa. E o segundo ano de noviciado foi bem diferente! [...] Eu falava: "nós estamos aqui, mas nossas cabeças não estão aqui, dentro do noviciado". [...] A gente só olha pra fora! Só se dedica pra fora. E quando a gente entra no noviciado é tempo da gente olhar pra dentro. E aí é que tem esse choque. É por isso que todo mundo tem um... um baque! Tanto que no novinter a partilha era comum, todo mundo tava no mesmo barco furado! Assim, de não estar conseguindo entrar no noviciado! [...] Ah, meu primeiro ano de noviciado... foi difícil! Aí eles perguntavam [o orientador espiritual e a formadora do segundo ano de noviciado] e a gente dizia. Ah, eles entendiam, porque não fomos as primeiras e nem as últimas! Mas foi, foi difícil!

[...] Aí eu: "irmã, que ano da graça é esse que todo mundo dizia que é o ano da graça? Não vi graça nenhuma!” Aí ela disse: “o ano da graça não significa que seja tudo mil maravilhas, tudo um mar de rosas, que seja... né? Só alegrias. Pode ser o ano mais difícil da vida da pessoa. E é um ano de graça!” E eu: é verdade! Porque depois eu passei na peneira, assim, o ano e eu: não, dá pra tirar várias coisas boas! Hoje eu reconheço que foi bom... bom, assim, eu consigo tirar proveito do primeiro ano! [...] No noviciado que é hora... não que não tenha nada de vida religiosa no aspirantado e noviciado. Tem. Mas assim, o principal mesmo, o foco, é... a pessoa em si. Tem ali os intervalos, tem ali os intermédios da congregação, da pessoa ser religiosa, da experiência com Deus... enfim! No noviciado é que aumenta. Porque quem entra no noviciado já tem um pouco mais de consciência de que quer ser religiosa mesmo! [grifos do pesquisador]. (segunda entrevista)

$\mathrm{Na}$ segunda entrevista presencial, ao narrar experiências vividas no noviciado, a jovem recorre a uma narrativa bíblica, uma narrativa institucional, para atribuir significado aos próprios sentimentos e atitudes. A narrativa bíblica ${ }^{9}$ conta a história de duas irmãs que, ao receberem uma

$9 \quad$ "Jesus e os seus discípulos continuaram a sua viagem e chegaram a um povoado. Ali uma mulher chamada Marta o recebeu na casa dela. Maria, a sua irmã, sentou-se aos pés do Senhor e ficou ouvindo o que ele ensinava. Marta estava ocupada com todo o trabalho da casa. Então chegou perto de Jesus e perguntou:

- O senhor não se importa que a minha irmã me deixe sozinha com todo este trabalho? Mande que ela venha me ajudar.

Aí o Senhor respondeu:

- Marta, Marta, você está agitada e preocupada com muitas coisas, mas apenas uma é necessária! Maria escolheu a melhor de todas, e esta ninguém vai tomar dela” (Lc 10,38-42). 
visita de Jesus Cristo, têm atitudes bem diferentes. Marta, a irmã mais velha, empenha-se em preparar a casa para a visita, dedica-se ao trabalho doméstico para receber Jesus da melhor forma possível. Prepara algo para comerem e limpa o ambiente. Por sua vez, Maria, a irmã mais nova, senta-se aos pés de Jesus para ouvi-lo. Quer aprender seus ensinamentos e dedica toda sua atenção ao visitante, sem se levantar para ajudar a irmã. Marta reage à atitude da irmã reclamando e pedindo a Jesus que a repreenda, ao que Jesus responde: "Marta, Marta, por que te ocupas de tanta coisa, quando apenas uma é necessária?"

Meses depois da primeira entrevista, a Fátima utiliza uma leitura bíblica como recurso simbólico para sintetizar ajustamentos entre seus sentimentos e a pedagogia formativa da instituição. A jovem reconhece na formação um elemento simbólico orientador e organizador de modos de ser e de sentir. Ao se colocar no lugar da personagem Marta, posiciona a pedagogia formativa no papel de Maria, ou seja, aquela que se preocupa com o essencial.

6.2.3.3 O hábito religioso: "naquele momento, foi o que me chamou atenção"

O hábito religioso é um importante recurso simbólico na trajetória de vida da Fátima. Como um objeto carregado de simbolismo institucional e cultural, passará a ter um significado muito pessoal para a jovem. Como narrado em entrevista, apesar de participar ativamente do ambiente da igreja, sentindo vontade de estar mais naquele contexto, a garota não tinha muita noção do que era ser uma freira. Sua atenção pela vida religiosa consagrada foi despertada quando conheceu duas freiras que usavam hábito: "ainda era coroinha, mas então não tinha aquela consciência do que era freira, né? E aí vieram duas irmãs de hábito [...]”. Até então, ela não tinha conhecido uma freira que usava hábito, e aquele encontro com as irmãs lhe despertou um interesse pela vida das freiras: "o hábito foi uma coisa que me chamou atenção".

Ao narrar esse episódio da sua atração pelo hábito religioso, a Fátima faz questão de ressaltar: "eu não entrei na congregação por causa do hábito, até porque nossa congregação não usa hábito". E, de fato, ao se sentir atraída pelas vestimentas das freiras, ela ainda não conhecia o significado institucional do hábito religioso. Como um objeto cultural, o hábito possui uma história e representa um forte simbolismo. Inicialmente, a vestimenta religiosa causa admiração na garota e, com o tempo, mediado por narrativas socioculturais, passa a funcionar como recurso semiótico que, em diálogo com complexos semióticos, orienta modos de ser, agir e sentir da garota.

Naquele momento foi o que me chamou atenção. Aí eu vi aquelas duas irmãs lá, lindas, lindas... as irmãs todas de hábito, tudo fechado, mas o rosto... sabe quando transparece 
aquela felicidade, aquela coisa? Essas irmãs, essas pessoas são diferentes. Não por causa do hábito, mas o olhar, o sorriso, o jeito... [grifos do pesquisador]. (primeira entrevista)

O hábito, como elemento cultural, catalisa sentidos e significados em diferentes direções. A jovem entende gestos e atitudes como características que fazem daquelas freiras "pessoas diferentes". Valores e sentimentos socialmente destacados são percebidos nas freiras de hábito, os quais ainda não haviam sido percebidos, ou pelo menos não haviam sido ressaltados, em nenhuma outra irmã religiosa: "tudo fechado, mas o rosto... sabe quando transparece aquela felicidade, aquela coisa?" A admiração causada pelo hábito canaliza a atenção da garota para detalhes daquelas freiras - detalhes que talvez outras também possuíssem, mas que, provavelmente por não usarem hábito, não tinham sido ressaltados.

Na primeira entrevista, a Fátima já havia informado que, ao professar os votos religiosos, queria usar o hábito, mesmo sua congregação não o adotando como vestimenta, e portanto não tendo um modelo próprio. "A minha congregação não usa hábito, né, como eu tinha te dito. Mas $e u$ quero usar. Eu já falei pras irmãs: eu quero usar. Minha opção, assim, livre, ninguém nunca me disse nada". Era uma decisão pessoal e muito contestada pelas irmãs mais velhas, que diziam não encontrar sentido no desejo da jovem.

Eu sei que não é o hábito que faz a pessoa religiosa, não é. Mas o hábito, em todos os documentos da Igreja, em tudo, todo livro que diz respeito ao hábito é o sinal externo daquilo que eu vivo internamente. É o que eu mostro pros outros, aquilo que eu vivo. Não preciso daquela roupona pra me mostrar pros outros, posso mostrar com minha vida, minhas atitudes, o meu jeito. Mas o hábito é marcante. Pra mim, foi tão marcante no começo da história! No começo, né, da minha história vocacional. Então eu quero usar. E aí eu penso nisso [grifos do pesquisador]. (primeira entrevista).

Na busca de justificar seu desejo de usar hábito, a Fátima coloca em diálogo narrativas sociais, referentes ao hábito como elemento institucional (documentos da Igreja), e narrativas pessoais, relativas ao papel significativo do hábito na sua história vocacional. Assim, a partir do momento em que passa a conhecer a história e o significado do hábito nos documentos oficiais da Igreja Católica, a jovem cria significados que ajustam narrativas socioculturais e pessoais na construção de um sentido singular do hábito na sua trajetória. Portanto, o hábito como recurso simbólico é sustentado nas narrativas institucionais sobre ele.

Ao utilizar documentos oficiais da Igreja para justificar o sentido do hábito religioso (sinal externo daquilo que se vive internamente), a jovem ressalta que não depende dessa vestimenta para revelar o próprio ser. Portanto, não é o hábito que vai fazer dela uma freira, e sim suas atitudes. Porém, ele é um sinal que transmite uma mensagem por si mesmo.

A jovem começa a agir no presente em diálogo com um futuro imaginado: "vou cortar meu cabelo bem curtinho pra usar o hábito. E depois que eu começar a usar o hábito mesmo, vai ser 
quase que outro, né? Porque queira ou não queira, o hábito faz a diferença, assim, num ambiente que a gente está". Considerando a própria experiência com o hábito aos 12 anos e observando outros religiosos que também usavam hábito, a Fátima o utiliza como recurso simbólico em processos de transição de desenvolvimento. Ela interpreta no uso da vestimenta uma sugestão (ou exigência) de reorganização do prisma semiótico "eu-outro-objeto-sentido do objeto para o self" (Zittoun \& Perret Clermont, 2009). Como objeto cultural, o hábito se mostra capaz de reposicionar a pessoa nas esferas de experiência, sugerindo novos modos de ser, de sentir e de ser reconhecida.

O hábito exige coisas que a gente não gostaria de fazer. Tipo: cumprimentar todo mundo quando chega em um lugar. [...] Se eu chego com o hábito... depende do lugar, né? Uma casa de família, eu tenho que sair pegando na mão de todo mundo. [...] Eu penso nisso, que vai ter consequências, né, que vai ter consequências. Mas eu quero, né? Mas eu... tomara que seja uma dificuldade assim, não... que me faça desistir, mas tomara que me dê mais coisas pra eu crescer, pra eu avançar, né? [...] Quando a gente está em um grupo de muitos religiosos, quem está de hábito, principalmente irmãs, tem preferência em tudo. [...] E isso é um desafio pra gente, pra quem usa hábito. E eu já penso nisso, porque quero usar. Não, eu não vou deixar, não vou deixar o hábito falar mais alto do que eu, assim, a aparência, né? Quero ter meu lugar, quero que me respeitem, isso com hábito, sem hábito. Todo mundo é bem aceito, né? Mas não quero deixar o hábito, assim, me... me elevar tanto não. Tenho minha visão, assim, tenho um propósito. Não, eu quero usar hábito, mas não quero receber mordomias por causa dele, não [grifos do pesquisador]. (primeira entrevista).

Algumas possíveis consequências do uso do hábito também causam tensões entre esferas de experiência, em relação ao ajustamento entre o que se é e as expectativas que o hábito cria nas pessoas; por exemplo, de que uma irmã dispense mais atenção com as pessoas, cumprimentando-as individualmente. Esse é um exemplo simples trazido pela jovem, que nos remete a comportamentos que parecem esperados socialmente em decorrência da vestimenta. Podemos pensar aqui nos vários tipos de vestimentas que parecem sugerir comportamentos padronizados: policiais, bombeiros, enfermeiros, babás, serviços gerais, padres. Da mesma forma, a roupa, sendo um objeto cultural e simbólico, desperta sentimentos e sensações, tanto nas pessoas que as usam como naquelas que apenas as veem, a depender do contexto.

Na segunda entrevista, a Fátima já usava o hábito religioso. Era a única irmã naquela congregação a usá-lo. A jovem apresentou uma longa narrativa, em que complexos semióticos em diálogo com o recurso simbólico hábito religioso revelam significados fundamentados em narrativas institucionalizadas e em experiências vividas. Nessa construção de sentidos de continuidade de si, o hábito, como elemento simbólico, orienta e amplia o sistema de self da jovem.

E eu fiz uma opção pra usar hábito. Mas ninguém usa! [...] Até um detalhe importante isso aí na caminhada, porque também não foi no dia da profissão, não foi no ano da profissão, 
mas já sempre eu vim pensando nisso! Sempre falava. [...] Não foi da noite pro dia! Só foi confirmando. Aí eu fui discernindo. Aí teve um trabalho de discernimento sobre o hábito, porque os orientadores: "mas porquê, Fátima? Ninguém usa hábito!" "Ah, mas eu quero usar! [risos]". Aí eu fiz um trabalho direitinho, peguei os documentos da Igreja. E os documentos tinham umas palavras que eu nem conhecia! Aí eu peguei os documentos da Igreja e eles expressam bem, Direito Canônico, dizem assim: "o hábito é um sinal externo da consagração". Aí tem lá: “cada instituto, cada congregação, adapte às suas regras". É tanto que no meu trabalho eu comecei... peguei o Código do Direito Canônico [...], Diretório Geral, que é da minha congregação, Diretório Provincial, que já é da minha província, e as Constituições, que também é da congregação toda. E aí eu fui pegando os números que falavam do hábito. E aí, realmente, tem um que diz lá, o Diretório Geral, ele diz assim: "o nosso hábito consiste em: um vestido simples"; não significa que seja um vestido em si. É uma vestimenta, uma veste, né? “Um vestido simples, um véu e um anel com o crucifixo". [...] Peguei o Diretório Provincial e aí dizia a mesma coisa, só estava repetindo. E as constituições não falavam no que consistia, mas tinha lá as explicações: "é um sinal externo da consagração, é um sinal de pobreza". E eu falei: "olha que bonito, né?" E tem um sentido assim... religioso o hábito, né? Não é uma aparência, né? Não é só aparência.

Aí eu comecei a escrever. Peguei os documentos e escrevi o que eu achava, meus argumentos. Até usei... que as irmãs todas diziam: "pra que, Fátima, que você vai usar hábito? Ninguém usa!" "Não, eu quero usar." “Ah, não é o hábito que faz o monge”. Aí eu: "ótimo!" Coloquei no meu trabalho: não é o hábito que faz o monge. Se fosse o hábito que fizesse o monge, eu não iria querer usar, porque eu iria deixar de ser a Fátima pra ser... não sei... para entrar na mágica do hábito, né? Quando coloca o hábito, muda! Então eu falei: graças a Deus que não é o hábito que faz o monge, porque eu não vou deixar de ser $e u$, eu Fátima. Mas por esse sinal externo! Porque nem todas as irmãs que não usam hábito a gente identifica logo que é uma pessoa consagrada a Deus. Não que não seja... não que seja menos. Não que a pessoa que usa hábito seja mais! Mas não é! E como... Francisco também disse uma vez, esse né, o santo: "evangeliza sempre, se precisar usa palavras". E $o$ hábito, ele ajuda muito! Ele é uma mão na roda nesse sentido! A gente passa na rua, tem gente que pede bênção, tem gente que faz o sinal da cruz. E qualquer pessoa, de religião ou sem religião, quando olhar pra uma pessoa de hábito, lembra de Deus, pensa em Deus! [...] A pessoa lembra da igreja, lembra de alguma coisa assim religiosa, né? Quando a gente vê um policial vestido de policial, a gente sabe que ele é policial, né? 
E enfim, eu falei: não, eu quero usar hábito! Eu vou usar hábito. E tem muitas críticas. Ainda hoje as irmãs... mas só assim, pessoas da casa. [...] Mas a maioria dos religiosos entende! E principalmente do povo de fora, eu recebo muitos elogios do povo de fora. [...] Sei lá... é diferente, né? [...] Só que eu não levo isso pra cabeça, eu não deixo me influenciar por isso! Mas assim, eu fico pensando nas irmãs da minha congregação. Só elas que criticam! Só elas que não veem nada de positivo: "Ave Maria, inventando moda... não sei o quê... essa juventude que chega assim... inventando coisa". [...] A irmã que foi minha formadora no segundo ano do noviciado, ela me ajudou bastante neste sentido do modelo, porque ela me perguntava: “Fátima, que modelo?” Eu: “sei lá, irmã, eu tô lá pensando em modelo! Eu sei que eu quero usar hábito! Eu não estou pensando em modelo, não" [grifos do pesquisador].

A palavra "discernimento" tem um sentido importante na formação de jovens para a vida religiosa consagrada. Discernir é a capacidade de conhecer o objeto em discernimento e assim ter condições de fazer a escolha certa; por exemplo, discerne-se sobre a própria vocação, sobre a vontade de Deus, sobre a própria missão como religioso. No contexto religioso, discernir remete a um olhar para dentro, à busca de resposta mediante um diálogo interno entre mim e Deus. Portanto, no campo religioso, o discernimento é fundamentado na vontade divina.

A decisão pelo hábito foi um discernimento, intensificado na experiência do noviciado. Ao mesmo tempo, foi uma resistência ao presente, à realidade, em função de um vir a ser. A Fátima enfrenta críticas, principalmente das irmãs que convivem com ela na mesma congregação. Essas críticas são colocadas em diálogo com as narrativas institucionalizadas sobre o hábito religioso, em busca de criar uma narrativa pessoal que apresente argumentos suficientemente fundamentados para resistir à pressão sofrida pela jovem dentro da própria instituição religiosa.

O hábito religioso, como um recurso simbólico, possui historicidade e significados culturais institucionalizados, mas também, para a Fátima, sempre teve um sentido singular — uma construção semiótica que ela começou a elaborar desde o encontro com as duas freiras que usavam hábito, quando ela ainda não havia decidido ser religiosa consagrada nem se considerava vocacionada para tal. Ao ser questionada sobre possíveis relações entre o episódio das freiras de hábito e a sua escolha por usar hábito, ela responde:

Eu nunca tinha pensado, lembrado disso. E um frei que me acompanhou e era orientador espiritual no segundo ano de noviciado era psicólogo. [...] Quando eu fui falar pra ele, me veio na hora: que foi as duas irmãs! Falei: "gente, eu fui atraída!” Não pelo hábito, mas assim... não, não pela roupa, mas foram as irmãs... elas usavam hábito, que me chamara atenção. E lá na comunidade sempre teve freiras, sempre teve irmãs, que não usam. E eu nunca tinha me tocado, nunca tinha caído a ficha. Aí, quando eu falei pra ele, eu falei: 
"gente, olha como é interessante, né? Tem a ver!” Aí ele foi e disse: “claro, claro!” [...] Quando ele perguntou, a primeira coisa que veio foi as duas irmãs que eu vi na minha comunidade, quando eu era pequena, quando eu era criança, que eu falei: "ah, eu quero ser é freira!" Que eu sabia que eu queria ser uma coisa diferente, eu não sabia que era freira.

$\mathrm{Na}$ primeira entrevista, a jovem parece resistir à ideia da influência do hábito na sua história vocacional ("detalhe, eu não entrei na congregação por causa do hábito"), e para não deixar dúvida disso acrescenta: "até porque nossa congregação não usa hábito". Porém, desde o primeiro ano de formação religiosa, ela fala que quer usar hábito - "as irmãs que me conheceram como aspirante falavam: "ah, eu não estranhei, não, porque você sempre falava". Na segunda entrevista, a jovem reconhece a influência daquele encontro com as freiras de hábito. Se antes ela resistia à relação entre o encanto pelo hábito das irmãs alegres e sua vontade, numa releitura, ela reconhece que o ingressar em uma congregação onde ninguém usava hábito não foi impedimento para que ela desejasse usar esse sinal externo da sua consagração. Na nova leitura dessa relação, pode-se considerar, também, que as vozes institucionais, tanto dos documentos da igreja e da congregação como do psicólogo, seu orientador espiritual durante o segundo ano de noviciado, tiveram papel importante na legitimação dessa ideia: "aí ele foi e disse: 'claro, claro!"”

A seguir, abordo o elemento cultural consagração religiosa, destacando o modo como a Fátima internaliza ou externaliza esse elemento como recurso simbólico que, integrando o seu sistema de self, possibilita novos limites e continuidades.

6.2.3.4 A consagração religiosa: "agora eu entendi que a vida consagrada é o dia a dia"

A vida religiosa ou vida consagrada, considerando os fundamentos teóricos deste estudo, é entendida como um recurso simbólico, uma sugestão socioinstitucional e cultural de modos de ser, agir e sentir no mundo. Ao se interessarem pela vida religiosa consagrada, os quatro participantes deste estudo não tinham amplo conhecimento da dinâmica daquele modo de vida. A Cecília, por exemplo, é a única que não cita a freira ou o padre como figuras importantes na emergência da sua vocação para a vida religiosa. Também ela é a única, neste estudo, que não foi coroinha e, portanto, teve uma participação menos intensa na igreja quando criança e adolescente. Por sua vez, a Fátima, o Francisco e o Vicente estiveram inseridos nesse contexto desde muito cedo, o que contribuiu no modo singular como compreenderam a dinâmica da vida religiosa.

Com particularidades, para cada participante, a vida religiosa consagrada é apresentada como um elemento cultural afetivamente valorizado. Entre os significados em torno da vida religiosa consagrada, merece destaque o signo diferente. Os quatro participantes, de um modo ou 
de outro, projetam na vida religiosa consagrada a possibilidade de viver o algo diferente que sentiam, mas que nem sempre conseguiam definir em palavras. A Fátima, por exemplo, conta que sentia algo diferente, mas não sabia que aquilo era ser freira. Em sua primeira entrevista, ela utiliza a palavra "diferente" em nove situações. Em geral, refere-se a uma disparidade entre o seu comportamento, seu modo de pensar, e o de outros. E ao longo da sua trajetória de vida esse sentirse diferente vai sendo descrito como ser vocacionada para a religiosa consagrada, considerando que o significado institucional de vida consagrada será negociado mediante a pedagogia de formação no convento.

Ambiente que tem padre, ambiente que tem freira, ambiente que... tem uma vida assim diferente, né? Eu gostava. [...] Eu tinha realmente um comportamento diferente dentro da sala pelo fato de eu ser coroinha e ser toda de dentro da igreja. [...] Mas eu me percebia diferente. [...] Outras crianças que eram coroinhas também, a gente via. Eu também percebia neles: "ah, eles são diferentes". Então, não é só eu que sou diferente por ser coroinha. [...] As irmãs todas de hábito, tudo fechado, mas o rosto... sabe quando transparece aquela felicidade, aquela coisa? Essas irmãs, essas pessoas são diferentes. [...] E eu desde pequena já participava, porque outras pessoas da comunidade me indicavam. Diziam pro padre: "padre, chama a Fátima! Chama a filha da dona [Fulana], que ela é diferente". [...] A ideia é muito boa de ir, fazer a experiência, conhecer uma coisa nova, né, uma vida diferente da minha. [...] Mas a vida também que é diferente de todo profissional, de qualquer leigo, né? É a vida de oração, vida comunitária! [...] Eu sou novinha e tudo eu quero as coisas assim... jovem tem um jeito diferente de fazer as coisas... de novidade [grifos do pesquisador]. (primeira entrevista)

O ser diferente parece um sentido orientador de escolhas ao longo da trajetória de desenvolvimento da Fátima. Coisas diferentes, pessoas diferentes, espaços diferentes, comportamentos diferentes parecem estar na preferência da jovem. Nos ambientes em que esteve, ela se esforçou por fazer diferente, querer algo diferente, resistir ao presente (ao real) em função do imaginado (o vir a ser). A própria decisão pelo uso do hábito foi um diferencial na realidade da sua instituição religiosa, onde ninguém tivera tal atitude até então.

Esse sentir-se diferente igualmente era uma sugestão social, pois as pessoas também viam a Fátima como diferente. Sentimentos de bem-estar, de satisfação, de realização em ser coroinha, em participar da igreja, são com o tempo interpretados em diálogo com o elemento cultural religioso consagrado. Esse processo vai se construindo em diálogo com a pedagogia de formação do convento.

Não é que eu fiquei pronta agora, depois de irmã, mas de agora que eu reconheço que $e u$ estou muito diferente, talvez pra melhor um pouco e muita coisa pra melhorar, com consciência de muita coisa pra melhorar, depois de ter entrado na congregação. [...] A 
Fátima de hoje que é a irmã, mas que é bem diferente da Fátima do começo [grifos do pesquisador]. (segunda entrevista)

O ser religioso consagrado é um aprendizado. Os jovens ingressam em uma congregação ou ordem e, dentro de uma pedagogia específica, vão se constituindo religiosos consagrados. Portanto, são oferecidos limites e possibilidades de ação, de ser e sentir naquela e em outras esferas de experiência. E aquilo que começou como "uma inquietação", um sentimento nebuloso, é transformado em vida religiosa consagrada, numa relação dialógica entre pessoal e institucional.

A Fátima gostava de estar no ambiente da igreja, gostava de realizar as atividades que aquele local oferecia. Gostava de outros ambientes também, mas aquele a atraía de modo especial, afetivamente falando, e tinha forte influência sobre a garota: "algo deve ter me atraído ali naquele ambiente, porque... quantas pessoas cresceram na Igreja Católica e depois se desviaram?" Portanto, gostar e estar no ambiente da igreja não era o suficiente. Mas algo a inquietava, "eu quero mais, eu gosto disso daqui, mas eu quero mais disso daqui. [...] Isso foi crescendo em mim, cada vez eu gostava mais, cada vez... quanto mais fazia, mais queria fazer". E esse desejo de estar cada vez mais naquele ambiente, fazer mais aquele trabalho na igreja, foi compreendido como o desejo de ser freira - uma construção de significado catalisada pela figura do hábito religioso e pela expressão de felicidade das freiras, "as irmãs todas de hábito, tudo fechado, mas o rosto... sabe quando transparece aquela felicidade, aquela coisa? Essas irmãs, essas pessoas são diferentes".

A partir de então, a garota reconhece na figura das freiras (e mais tarde na consagração religiosa) a possibilidade de viver o seu modo de ser diferente, o seu gosto pelo ambiente da igreja. "Falei: 'olha, eu sempre quis o algo mais dentro disso aqui que eu gosto. Então, talvez seja isso daí." Ao interpretar de maneira singular comportamentos e modos de ser e de sentir culturalmente reforçados, a Fátima constrói processos de continuidade e sentido de si. O encantamento com o hábito e com a figura das freiras, num processo dialógico com esferas de experiência, vai sendo transformado num sentido pessoal do ser uma religiosa consagrada. E esse processo é possível a partir de relações dialógicas entre a jovem e o outro, especialmente pessoas, objetos e narrativas que representam a tradição da instituição religiosa.

Tem um porquê de ir, não é só porque eu quero ser freira, não. Realmente o fundamento de toda a nossa vida, de uma vida religiosa, é a pessoa de Jesus Cristo, né? E é tanto que a gente faz esses três votos, que é pobreza, castidade e obediência. E o fundamento maior é ele, que ele foi pobre, casto e obediente. Assim, todo o nosso espelho... cada congregação tem o seu carisma, tem seus fundadores, tem sua missão diferente, mas tudo se resume em Jesus, né? No caso, o fundamento é o mesmo [grifos do pesquisador]. (primeira entrevista) $\mathrm{Na}$ relação com o institucional, a Fátima ressignifica sua vocação religiosa, agora fundamentada na pessoa de Jesus Cristo. Querer ser freira não é o suficiente; é preciso estar aberta aos ajustes entre o pessoal e institucional. É preciso desenvolver a capacidade de ressignificar os 
próprios sentimentos, desejos e inquietações em diálogo com narrativas, objetos e elementos institucionais.

Aquele negócio de morar com mais seis pessoas dentro de uma casa que você não conhece, não conhecia antes! Vai conhecendo ali toda a vida... o ano todo conhecendo! É... cada uma é de um lugar diferente. Gente do norte ao sul dentro da mesma casa. De região diferente, de jeito diferente, de cultura diferente, tudo diferente, mas aquilo dali conta... aquilo dali também faz valer a nossa vida, a nossa opção pela vida religiosa, né? E a vida de oração que... pra mim sempre foi mais forte! Sempre! Desde pequena, desde criança, desde antes de entrar na congregação. Gostar de rezar [...]. Vida religiosa é todo um contexto. Não é só a congregação, não é só a casa que eu estou. Tudo, tudo, a vida da gente é outra. [...] Mas o fundamento disso tudo é Deus. É a vida de oração [grifos do pesquisador]. (primeira entrevista)

As experiências vividas no contexto da formação religiosa são vistas pela Fátima sempre em diálogo com sua história e seus horizontes futuros. A jovem utiliza-se de significados construídos anteriormente, bem como de objetivos a serem alcançados, para fazer sentido de si no momento presente, sempre em diálogo com elementos institucionais. Assim, a consagração religiosa, como um elemento cultural, torna-se um recurso simbólico para a jovem. Ao esforçar-se para manter seu sentido de continuidade, uma das formas utilizadas para promover essa transição de desenvolvimento é fazer uso dos recursos simbólicos disponíveis na cultura institucional.

São várias as rupturas demandadas na formação para a vida religiosa. E a superação dessas rupturas exige mudanças significativas que atuam como catalisadores na emergência de novos processos e modos de sentir, agir e pensar. Na busca de readaptação às realidades, novas reorganizações no sistema de self ocorrem visando restabelecer um sentido de continuidade de si. E, assim, recursos simbólicos são internalizados mediante as interações da jovem com o sistema cultural oferecido e organizado pela instituição religiosa. Esses recursos simbólicos oferecem meios para lidar com a incerteza do futuro, possibilitando a construção de novos sentidos de si e do mundo (Zittoun, 2006b; Zittoun \& Grossen, 2012).

Teve momento que eu partilhava com o padre: "padre, eu estou muito feliz. Muito! Sei lá, não dá pra explicar isso, não!" Aí ele: "isso é que é a vida religiosa. Isso é que é o dizer sim a Deus. É o dia a dia, não é o dia da profissão!" Eu: "ah, é?" "É, o dia a dia!” A pessoa vai se percebendo feliz. Tendo o sentido de vida, encontrando o sentido de vida dela, no dia a dia, sem ter nada assim de extraordinário. [...] É no dia a dia, no cotidiano. Com a questão dedicada da missão. [...] Eu canso, mas eu gosto de fazer! Me sinto bem com isso. [...] Eu sempre fui percebendo e cada dia se confirma. Aí eu falei: "ah, então agora eu entendi que a vida consagrada é o dia a dia, não é o dia da profissão'. Ele: “a consagração é o dia a dia" [grifos do pesquisador]. (segunda entrevista). 
Portanto, o uso do recurso simbólico consagração possibilita à Fátima um movimento semiótico em direção ao passado e ao futuro, em direção àquilo que ainda não é, mas que pode vir a ser — agindo como se... (Zittoun, 2006a) —, mas também em direção àquilo que é passado, mas que continua passível de ressignificações a partir da experiência presente. Isso é possível pela mediação de recursos simbólicos que antes não estavam disponíveis, mas que agora integram o sistema de self. Trata-se de um processo fundamental na representação de movimentos transicionais, num espaço-tempo de desenvolvimento.

\subsection{Caso Francisco: a organização do sistema de self na zona de fronteira entre o dentro e o fora do convento}

\subsubsection{Momentos de entrevista e construção de informações}

O primeiro encontro com o Francisco se deu em 4 de setembro de 2014, no convento onde ele, assim como a Fátima, participava de um encontro de noviços, na cidade de Goiânia. A Fátima e o Francisco não moravam em Goiânia e eu só teria aquela oportunidade para entrevistá-los pessoalmente antes da minha saída para o estágio de doutorado sanduíche em Portugal. Por isso, ambos não responderam ao Guia de Evocação de Narrativas Escritas, e a primeira entrevista, do tipo história de vida, foi realizada logo naquele primeiro encontro.

$\mathrm{Na}$ oportunidade, expliquei os objetivos do estudo e solicitei a assinatura do Termo de Consentimento Livre e Esclarecido; além disso, falei sobre a metodologia do estudo e dos possíveis futuros encontros. Na época, o Francisco estava com 24 anos, sendo aquele seu terceiro ano na formação religiosa, ano do seu noviciado. O noviciado, naquele instituto de vida consagrada, tem duração de doze meses, e o Francisco iria professar seus primeiros votos em torno de trinta dias após nossa primeira entrevista.

Conversamos sobre a história da sua vocação para a vida religiosa abordando temas como família, infância, adolescência, estudos, trabalho, contexto formativo da instituição religiosa e perspectivas. Após aquele primeiro encontro, continuei em contato com o Francisco por meio de Whatsapp, telefone e Skype. Em fevereiro de 2015, já professo temporário, ele ingressou no curso de filosofia, passando a residir em outro estado brasileiro. Nas oportunidades que tivemos de conversar, falamos do final do ano de noviciado, da vivência e profissão dos votos temporários, da mudança de casa de formação, cidade e formador, do ingresso no contexto universitário, das pastorais, de sua condição de saúde e das perspectivas em relação ao futuro. 
A segunda entrevista presencial com o jovem ocorreu em 13 de novembro de 2015, nas dependências de um convento, também em Goiânia, quando ele estava na cidade para uma consulta médica (roteiro utilizado em anexo VIII). Na oportunidade voltamos a conversar, de modo mais aprofundado, sobre a experiência da celebração dos primeiros votos, o significado dos votos religiosos (pobreza, castidade e obediência), o sentido de ser agora um religioso consagrado, reconhecido pela Igreja e pela comunidade, a experiência como estudante universitário de filosofia, sua condição de saúde e suas perspectivas.

Após a última entrevista presencial, mantive contato com o Francisco mediante redes sociais, especialmente via Whatsapp, o que também ocorreu com os participantes Fátima e Vicente.

\subsubsection{Caracterização do caso}

Francisco, o caçula da família, cresceu com a mãe, a avó e duas irmãs numa cidade do interior. Sua mãe era catequista ${ }^{10}$ e participava da missa todos os finais de semana. Já sua avó ia à igreja praticamente todos os dias e, frequentemente, levava o Francisco com ela. Assim, ainda criança ele começou a vivenciar momentos e eventos religiosos mediados especialmente pela família. Francisco costumava participar da missa das crianças, momentos dos quais se recorda com alegria. Segundo ele, sua avó conta que um dia, aos 6 anos, ele disse que queria ser como "aquele homem lá em cima": o padre que celebrava a missa no altar. Essa admiração pela figura do padre é recorrente na narrativa de outros participantes da pesquisa. Em geral, ressaltam a admiração pelas vestes que o padre usava, pelo respeito que todos tinham pelo padre e por ser ele o centro das atenções em todos os eventos religiosos.

Desde o nascimento, Francisco apresentou problemas sérios de saúde. Ao nascer, ficou nove meses na UTI, aos 2 anos fez um transplante de medula, aos 6 fez a primeira cirurgia para retirada de cálculo renal, que precisou ser repetida algumas vezes. Segundo o próprio Francisco, entre os 12 e os 16 anos, os problemas de saúde se agravaram. Aos 10 anos, Francisco começou a participar do grupo de coroinhas, ajudando o padre nas missas realizadas na sua comunidade. Nessa mesma época, participou da catequese em preparação para o sacramento da eucaristia. Aos 13, tornou-se catequista, como sua mãe, e no ano seguinte, 2005, iniciou um acompanhamento vocacional, vindo a ingressar em um instituto de vida consagrada. Ele tinha então 14 anos e ainda

10 Pessoa responsável por acompanhar as crianças em preparação para receber o sacramento da eucaristia (primeira comunhão). A catequese em geral tem duração de dois anos e é frequentada por crianças entre 8 e 11 anos. 
cursava o primeiro ano do ensino médio. Entretanto, permaneceu no instituto apenas um ano, precisando retornar para casa, por orientação dos representantes da instituição e contra sua vontade, devido ao agravamento do seu quadro de saúde.

De volta à casa da mãe, terminou o ensino médio com muita dificuldade, devido às constantes internações hospitalares. Em 2007, mudou-se para uma capital, onde morava uma de suas irmãs, recém-casada, no intuito de fazer um acompanhamento médico mais intenso. Na nova cidade, começou a participar das missas em uma paróquia próxima à casa da irmã. Fez amizade com alguns dos padres responsáveis pela paróquia, revelando-lhes seu desejo de ser religioso consagrado e solicitando acompanhamento vocacional.

Em 2011, o Francisco foi aceito para participar dos encontros vocacionais, iniciando assim um novo discernimento da sua vocação. Naquela altura, os responsáveis pelos encontros vocacionais, os mesmos que opinavam sobre o ingresso dos jovens na instituição, já sabiam das condições de saúde do Francisco. Em 2012, ele foi aceito para ingressar naquele instituto de vida consagrada e iniciou a etapa de formação postulantado, que durou dezoito meses. No final de 2013, foi aprovado para iniciar o noviciado.

Ao ser entrevistado pela primeira vez, Francisco era noviço havia aproximadamente onze meses e estava prestes a vivenciar um rito de passagem muito importante no contexto de vida consagrada: a celebração dos primeiros votos, a denominada profissão simples. Nesse rito, durante a celebração de uma missa, ele iria prometer viver, por um ano, os votos de pobreza, castidade e obediência. A partir de então, Francisco seria reconhecido como religioso pela Igreja Católica, tornando-se oficialmente membro daquele instituto de vida consagrada.

No início de 2015, o jovem ingressou no curso de filosofia, obrigatório para homens que pretendem ser religiosos consagrados e sacerdotes. Apesar de apreciar muito o ambiente universitário, na segunda entrevista presencial, quando já estava no final do segundo semestre do curso, Francisco afirmou ter tido muitas dificuldades em parte das disciplinas, que ele atribuiu às constantes hospitalizações, durante o ensino médio, e à pouca dedicação ao curso de filosofia que, segundo ele, se pudesse escolher, não cursaria.

\subsubsection{Movimentos semióticos e tensões dialógicas na trajetória de vida do Francisco}

Uma das formas pelas quais a cultura participa das configurações da subjetividade é pela oferta de imagens que, à luz da psicologia cultural, funcionam como agregados de significações, clusters (Roncancio Moreno, 2015) de crenças e valores culturais incorporados a um signo. Como narrado pelo próprio Francisco, desde criança ele esteve imerso em um ambiente fortemente 
orientado por valores religiosos, o que o levou a admirar a figura do padre. É possível que para o sujeito, ainda criança, na falta de elementos empíricos mais concretos para compreender signos tão abstratos como religião, fé, Deus, etc, um signo que representasse fenômenos como esses fosse sintetizado no ícone visual do padre. Assim, o posicionamento físico e simbólico do padre na celebração, suas vestes, a postura dos fiéis, dos familiares etc. reforçam uma representação do padre como autoridade digna de ser imitada.

A identificação do Francisco com a figura do padre é marcada por emoções positivas. Ele gostava de imitar o padre em brincadeiras com os colegas: "eu pegava o folheto da missa, né? Eu brincava de celebrar missa [risos]. Eu era o padre, aí minhas irmãs, meus vizinhos, meus primos assentávamos e ia brincar de celebrar missa". Naqueles momentos de brincadeira, reproduziam a celebração de uma missa, incluindo objetos, posturas, valores, crenças e vestimentas usadas pelo padre: "então pegava uma calça jeans, colocava sobre os ombros, fazia de estola ${ }^{11}$, cortava o lençol e fazia de casula ${ }^{12}$ ". A brincadeira dramatizava um contexto institucional, considerando gestos e posturas corporais, e sugerindo, de certa forma, atitudes e modos de relação do Francisco com os outros e consigo mesmo.

A avó, numa atitude de valorização daqueles momentos, colaborava na reprodução do cenário físico e simbólico: "minha vó estourava pipoca ou trazia aquelas bolachas Mabel, nós fazíamos de hóstia [risos]. E era sob duas espécies, minha vó fazia suco de uva [risos], então era sob duas espécies. Eu molhava e saía dando comunhão sob duas espécies pro povo". As performances de Francisco naquela brincadeira o faziam "semelhante" e mais próximo simbolicamente daquela pessoa e daquele lugar (o padre no altar da igreja) que the causavam admiração. A brincadeira possibilitava ao garoto, bem como aos seus pares, assumir posturas diferenciadas. No papel do padre, Francisco ocupava lugares e assumia comportamentos que, ao ganhar significados, tomavam espaço no seu sistema de self. Devem ser considerados também o apoio e encorajamento à brincadeira, por parte da avó, visto que nas duas entrevistas o Francisco, por várias vezes, reconhece a avó como uma pessoa importante na sua história vocacional. Ao mesmo tempo, as primeiras brincadeiras têm um elo simbólico com a "trajetória de padre", cuja próxima etapa seria a de se tornar coroinha.

Na narrativa do Francisco, ganha destaque esse evento em que foi "instituído coroinha". Ele menciona a felicidade que sentiu ao receber as vestes de coroinha, sob os olhares de seus

11 Estola é um paramento litúrgico cristão. É constituída por uma faixa de pano, normalmente de seda, com cerca de 1,5 a 2 metros de comprimento e 3 a $4 \mathrm{~cm}$ de largura, cujas extremidades podem ser retas ou ampliar para fora. O centro da estola é desgastado em torno da parte de trás do pescoço, e as duas extremidades pendem paralelas na frente, quer ligadas uma à outra ou soltas.

12 A casula é uma veste litúrgica confeccionada em seda ou damasco, tradicionalmente. As cores variam conforme o rito litúrgico. Utiliza-se sobre a túnica e a estola durante a celebração da missa. 
amigos da escola, que ele fez questão de convidar. Semelhante aos marcadores das brincadeiras de faz de conta, as vestes e responsabilidades de coroinha, agora de maneira formal, o aproximavam da figura do padre, ao mesmo tempo que o distanciavam dos demais, inclusive dos próprios colegas. A partir de então, ele participaria da missa no altar da igreja, com o padre, e não mais na plateia, onde estavam seus familiares e colegas. $\mathrm{O}$ evento parece funcionar como um rito de passagem legitimado pela instituição Igreja, a partir do qual o garoto ocupa outro espaço na comunidade, sugerindo novas posições identitárias. Nas palavras do Francisco, ele continuava a brincar de celebrar missa, "mas era com cálice, era com a âmbula, já era com as coisas da missa mesmo". É como se a brincadeira fosse se tornando realidade: os objetos passaram a ser reais, eram os mesmos usados pelo padre; agora faltava ele como padre se tornar "real". E, ao crescer, foi se "interessando cada vez mais por isso".

Considerando que, como os outros participantes, o Francisco foi convidado a narrar a história da sua vocação para a vida religiosa, esses eventos selecionados por ele (brincadeiras na infância, instituição como coroinha) se mostram como elos de continuidade em direção a uma vida sacerdotal. Num enquadramento idiográfico, esses são elementos significativos para a compreensão de trajetórias, destacando não ser regra que todos os garotos que foram coroinhas e que brincaram de celebrar missa se tornaram padres.

Os rituais podem promover campos afetivos hipergeneralizados (Valsiner, 2012), bem como momentos de ruptura (Zittoun, 2008), quando estes são reconhecidos como tais pelo próprio sujeito. O ser coroinha para Francisco, para além de um ofício, traz um novo espaço de ação e de construção identitária; gera responsabilidades na comunidade religiosa, reorganizando o prisma "eu-outro-objeto-sentido do objeto para mim" (Zittoun, 2008). Com isso, mudam as relações entre os elementos desse prisma e promovem-se processos de desenvolvimento do self, novas formas de se ver e se mostrar. As novas responsabilidades para com a comunidade na qual se participa possibilitam espaços de (re)negociação nas relações inter e intrapessoais.

Considerando suas crenças e seus valores, seu sentido de pertença e participação na comunidade religiosa, Francisco se torna um receptor de índices (vestes, biscoitos, suco de uva) e signos relacionados ao valor da religiosidade, da fé religiosa. $\mathrm{O}$ valor da crença religiosa funciona como uma lente pela qual o sujeito interpreta acontecimentos da vida cotidiana, relacionando-os ao discurso bíblico institucionalizado, e assim orienta suas perspectivas. Ao longo da sua ontogênese, a pessoa constrói e transforma sentidos de si e do mundo, ressignifica valores numa relação dialógica e negociada com valores sociais convertidos em signos hipergeneralizados. Os eventos e as ações cotidianas dialogam com os valores hipergeneralizados, e o sujeito atribui significado a tais valores de modo pessoal. 
6.3.3.1 Uma leitura da vocação religiosa mediada pela condição de saúde

$\mathrm{Na}$ infância, o sistema de self do Francisco tem como posições dominantes as que se referem à religião (eu como padre de brincadeira, eu todo dia na Igreja, eu como coroinha) e à identidade de gênero, constituída na condição de filho caçula, criado em meio a quatro mulheres. Ele não faz referência ao pai nas entrevistas. Nas suas narrativas, o padre é a figura masculina que ganha destaque.

Embora presente na infância, a doença não é relatada como algo tão significativo, um signo que afete o modo aparentemente feliz e positivo com que essa fase inicial é demarcada simbolicamente. "Eu como doente" torna-se uma posição preponderante quando tal condição passa a representar restrições relacionadas a outros campos de experiência, especialmente, a autonomia para atuar como coroinha e ao senso de futuridade em relação à posição 'eu como padre': "treze aos dezesseis anos foi uma fase bem turbulenta em questão de saúde, por que eu fui... tudo aquilo que eu gostava meio que eu fui privado...”. E o "tudo aquilo que eu gostava" era exatamente o ser coroinha, o participar na igreja e ser catequista. Assim, as complicações da saúde sugerem a possibilidade de não poder fazer tudo aquilo que gostava, o que mais tarde viria a transformar-se no "medo de não poder ser padre".

Ao se mudar para o seminário, pela primeira vez, em 2005, aos 14 anos, Francisco vivencia uma ruptura na sua trajetória de vida. Sai de uma cidade pequena, de junto da família, e vai morar em uma casa de formação com dezenas de adolescentes e jovens. Mesmo questionado sobre sentimentos, medos e anseios vividos na transição espacial e pessoal, o jovem pouco enfatiza o ingresso na primeira instituição religiosa como uma mudança significativa. Por outro lado, sua narrativa ressalta sentimentos causados por sua saída da instituição, devido à piora no seu quadro de saúde - uma experiência que, de certa forma, concretiza seu medo de que o problema de saúde o distancie do sonho de ser padre:

mas quando eu vi... se decidiu isso, meu chão meio que sumiu, porque era o que eu queria, era meu sonho. Aí eu falei assim: "pronto, agora... não vou ser padre...”, como se eu tivesse perdido o norte, digamos assim... uma frustração. [...] Quando entrei no quarto, chorei pra caramba... Internamente, estava destruído. [...] Era o fim. (primeira entrevista)

Vocação como alegria e autorrealização versus doença como frustração e tristeza: a partir de então, a tensão entre esses dois campos afetivos passa a orientar modos de ser e de sentir do Francisco nas diferentes esferas de experiência. A sua condição de saúde provoca uma tensão que o acompanha até a segunda entrevista presencial. Em todas as interações com o pesquisador, em momento algum o Francisco diz ter sentido dúvidas sobre sua vocação para a vida religiosa. Porém, repetidamente expressa o receio de não ser padre devido a seus problemas de saúde. A condição de 
saúde se coloca como um sentido catalisador na história vocacional do jovem. A relação consigo mesmo e com o Outro, inclusive com Deus, passa claramente a ser orientada pelo problema de saúde:

chegava a brigar com Deus quando sentia muitas dores... minha oração era um desabafo, uma cobrança com Deus... Eu brinco que foram as orações mais sinceras... [risos] que eu já fiz [risos]... não era uma revolta, mas era como se eu quisesse que ele agisse, como se eu quisesse chamar a atenção dele pra situação. (primeira entrevista)

De certa forma, a doença passa a ser um signo promotor de desenvolvimento em determinada direção, um signo que oferece tonalidades na interpretação afetiva de novos significados e modos de lidar com eventos do cotidiano. Dois episódios são considerados pelo Francisco como "um divisor de águas. Um Francisco antes, um depois..." dos acontecimentos. O primeiro episódio se deu no seu aniversário de 2006, de 16 anos, poucos meses depois de precisar sair da primeira instituição, e o segundo, no final do mesmo ano, pouco antes de se mudar para a casa da sua irmã, em 2007:

eu achava que a doença me tiraria a vocação. Então, meio que eu negava a doença e o tratamento. Não é que eu negava o tratamento, é que eu queria que o tratamento me desse a cura para que isso não me impedisse mais de ser padre, de ser religioso. [...] Então a doença, até o meu aniversário de 2006, foi quando eu ganhei um presente que fez uma coisa muito boa" [grifos do pesquisador]. (primeira entrevista).

Naquele dia, o Francisco estava sentindo muitas dores e ganhou de presente de aniversário um $\mathrm{CD}$ do cantor e padre Fábio de Melo. O amigo que lhe presenteou destacou uma música, "Não desista do amor", sugerindo que ele a escutasse sempre que estivesse passando mal, e que fizesse daquela música a sua principal oração. Segundo o Francisco, a letra da música foi escrita durante uma visita do padre Fábio de Melo a um amigo que estava em estado terminal de câncer e sentia muitas dores. Em meio às dores, o amigo pediu ao padre um pedaço de papel e uma caneta e escreveu a música, que o padre Fábio gravou após a morte do amigo. Francisco parece se identificar com essa história de sofrimento e, considerando a sugestão do amigo, procura utilizar aquelas palavras como ferramentas semióticas numa tentativa de ressignificação do próprio estado de saúde: "aí essa música é que vai me ajudar durante todo o resto de minha vida, até hoje [risos]. A partir de então eu vejo minha vocação de outra forma".

O segundo episódio ocorreu em um retiro espiritual do qual Francisco participou durante três semanas, antes de se mudar para a casa da irmã. O retiro tinha como ponto de partida a reflexão sobre um livro intitulado Tecendo o fio de ouro (Nogueira \& Lemos, 2013). O fio de ouro, segundo o Francisco, é a vida da pessoa e, inspirado no livro, cada participante deveria escrever a própria história de vida durante o retiro, considerando o passado, o presente e as perspectivas de futuro. 
Durante o retiro, um orientador periodicamente sentava com o participante e refletia sobre o que ele havia escrito. Francisco teve como orientador um arcebispo que ele admirava muito, o dom Justino (nome fictício). Conta que escreveu muitas coisas e, inclusive, expressou raiva ao falar da sua doença e da possibilidade de não ser padre. E isso levou seu orientador a sugerir que ele desse mais ênfase às coisas boas que já tinham acontecido ou que poderiam acontecer na sua vida — uma sugestão de releitura de si e da própria história.

De certa forma, nesse retiro, o Francisco viveu uma experiência similar à da sua participação na pesquisa, algo que na verdade é recorrente para um vocacionado à vida religiosa: falar sobre a história da própria vocação e sobre seus planos. Os outros participantes narram experiências parecidas, em que precisaram pensar sobre a própria história, vivida e imaginada, e narrá-la. Talvez por isso eles tenham se convertido em "bons" participantes, pelas vivências anteriores de contar a própria trajetória de vida.

Da experiência vivida com o arcebispo dom Justino como seu orientador espiritual, Francisco diz que as palavras do bispo, ao comentar seu "livro da vida", o marcaram muito:

olha, se Deus nos quisesse perfeitos, ele tinha nos feito perfeitos, ponto. Se ele não nos fez perfeitos, a sua cruz é isso! O seu problema está em não assumir, em não aceitar sua cruz. E quando você assumir, aceitar sua cruz, você vai conseguir aquilo que você quer, e aquilo que Deus quer pra você. Então o problema está aí, não está na sua doença, não está em todas as outras coisas. O problema está em você não aceitar aquilo que você tem, a sua limitação. O problema é você querer ser perfeito e você não é! Se você quer, se esse é seu desejo e se você acha que é de Deus esse desejo, então tem calma, que na hora de Deus vai acontecer. Mas lembrando que essa é sua cruz [grifos do pesquisador]. (primeira entrevista)

A fala do bispo, narrada sem pausas pelo jovem, parece ter um sentido orientador afetivamente forte. Essa carga afetiva pode ser devida ao lugar que o bispo ocupa na instituição igreja e/ou ao papel orientador que ele desempenhava naquele rito (retiro), o que the confere uma dupla legitimação para sugerir a Francisco novos sentidos de si. E suas sugestões convergem com sentidos emergentes da letra da música, funcionando para o Francisco como um recurso simbólico (Zittoun, 2006a) que assume papel importante como catalisador de trajetórias. Talvez por isso o jovem destaque esses dois episódios como “divisores de águas”.

A ressignificação da doença, proposta pelo bispo, sugere reposicionamentos no sistema de self do Francisco, criando novas tensões dialógicas:

e aí ele falava uma coisa que até hoje eu brinco com ele que eu não concordo, discordo. Falou assim: "olha, vou te ser bem sincero". Ele é fantástico... mas isso até hoje me dói por dentro, quando ele fala... ele falou assim: "eu acho que você não vai ter a cura da sua 
doença. Eu acho que você vai morrer com ela. Mas eu acredito que a sua doença é a cruz que vai te levar, e levar outras pessoas" [grifos do pesquisador] (primeira entrevista)

Francisco vivencia a tensão entre resistência e assujeitamento ao significado que o outro (o bispo) dá à sua existência. $\mathrm{O}$ arcebispo, mais que o padre no altar, está internalizado como figura de poder, voz de Deus. Ele constrói um enredo para o Francisco performar: resignar-se à doença, seguir na fé e no ministério, ser para outras pessoas exemplo de força e resignação. $\mathrm{O}$ arcebispo representa, então, um agregado de significados institucionais que foram internalizados pelo Francisco, de modo afetivamente singular, desde a infância, e que participam no modo como o jovem "assume" a possibilidade de futuro que lhe é "ofertada". Assim, entender a doença como algo bom e divino exige do Francisco aceitar sua condição, e rejeitar a doença seria rejeitar algo divino, a "cruz dada por Deus".

A letra da música e os posicionamentos do bispo apresentam sugestões de um novo olhar sobre o sofrimento, tema muito presente no cristianismo, onde sofrer pode ser caracterizado como o caminho mais estreito, mais difícil de ser percorrido, logo digno de recompensa ("Tome a sua cruz e siga-me"). O sofrimento no sentido bíblico é usado como um rótulo em diferentes níveis de generalização. No caso Francisco, é sugerido como campo abstraído e hipergeneralizado, regulador de afeto. O novo sentido recomendado sobre a doença impõe modos de ser e de sentir orientadores de novos posicionamentos, perspectivas e emoções, às vezes contraditórias entre si:

a música e o acompanhamento com ele [o bispo] foram de suma importância, porque eu fiz uma outra releitura... eu via a minha dor, meu sofrimento como um... como graça. Pode parecer até loucura. Talvez pode ser até... talvez para aliviar, a gente diga que seja graça... eu prefiro ver assim, que a minha dor, que aquilo que eu sinto, é graça, é... também vem de Deus, é dom de Deus, do que ficar batendo de frente, do que ficar brigando. Do que ficar discutindo com ele, do que querer que modifique [grifos do pesquisador]. (primeira entrevista)

Ao fazer parte da trajetória de vida do Francisco, a tensão entre resignação e resistência à doença canaliza modos de ser, sentir e agir no mundo. O jovem parece buscar compreender a doença como graça, mas sem querer desacreditar na possibilidade de ser curado. Por um lado, vê na letra da música e nas palavras do bispo a possibilidade de amenizar sua angústia, mediante a resignação; por outro resiste, quer discordar e acreditar na própria cura, afastando não só a dor física como também o medo de não poder ser padre. Essa tensão engloba sentidos sobre a doença sugeridos pelas autoridades religiosas e pelas autoridades médicas: "isso ainda me incomoda... porque assim, eu ainda acredito que eu vou ser curado. Sabe quando você acredita, mas não acredita? É mais ou menos assim. É... eu acredito, mas ao mesmo tempo fico com um pé atrás".

Como um signo catalisador, o sofrimento vai sendo reconhecido e transformado pelo Francisco em uma ferramenta de regulação de afetos. O jovem encontra no discurso teológico da 
igreja, reproduzido na fala do bispo e na letra da música, uma legitimação dessa internalização do sofrimento na regulação de modos de ser e sentir. Apesar de lhe parecer um caminho que deve ser seguido, tal sugestão lhe causa dor e angústia. Na busca de resolver tensões, repete para si mesmo que é "melhor acreditar que é graça".

A persistência do sofrimento tem um novo significado — o de uma purificação mediante o amor compassivo de Deus, que enviou o sofrimento como um amigo da alma. Ao unir esses dois pensamentos, o cristianismo conseguiu, aparentemente, sem reinterpretação, ter êxito em integrar a total gravidade e miséria do sofrimento, e sua redenção, como um fator essencial na ordem do mundo. Apesar do tormento aí envolvido, o cristianismo teve êxito quanto a fazer do sofrimento um amigo da alma acolhido com prazer, e não um inimigo ao qual resistir. Sofrimento é purificação; não punição nem correção. (Scheler, 1992, citado por Valsiner, 2012, p. 264)

O sofrimento visto como purificação e não como punição, como graça de Deus, é uma construção histórica e social, institucionalmente reforçada. E manter o foco nessa orientação semiótica ajuda o Francisco a dar sentido às suas metas pessoais. O novo significado do sofrimento sugere uma outra forma de se relacionar consigo mesmo, com seus sonhos e com sua vocação. Parece que, ao ver o sofrimento como graça divina, ele afugenta a ideia de que a doença pode impedi-lo de ser padre. Por outro lado, talvez o desejo de ser curado seja maior que o desejo de ser padre. Assim, mais que ameaçar o futuro como sacerdote, a doença ameaça a possibilidade de vida futura, uma discussão retomada adiante.

Nesse sentido, o sofrimento é signo reforçado socialmente, estando presente em muitas passagens bíblicas e na biografia de muitos santos reconhecidos pela Igreja. Francisco já havia tido contato com esse conteúdo, inclusive no episódio da música escrita pelo amigo do padre Fábio. Porém, na voz do bispo, essa sugestão se mostrou mais concreta, determinante e legítima.

Ao internalizar um valor geral, por exemplo, o sofrimento como meio de purificação e maneira de viver a fé, o sujeito reconstrói esse valor e acaba por externalizá-lo como sentido pessoal. Dessa forma, a relevância dada ao valor sugerido socialmente integra o desenvolvimento do sujeito, participando da consolidação de um modo de ser, perceber e vivenciar as coisas. A doença e a vocação para o sacerdócio, inicialmente, são significados vividos como contraditórios pelo Francisco ("eu achava que a doença me tiraria a vocação"). Considerando a trajetória vivida (entrada e saída na primeira instituição religiosa, tratamento médico, pouca evolução no tratamento no quadro de saúde, ausência de perspectiva de cura), ele tende a acreditar — ora mais, ora menos - que conseguiria chegar a ser padre. Após experienciar os dois episódios, inclusive se definindo como "outro Francisco", há uma busca por integração desses opostos mediante o signo catalisador sugerido socialmente: o sofrimento como ferramenta simbólica, que representa uma graça de Deus, uma cruz para ajudar outras pessoas. 
Instituições sociais, como igreja, escola e família, sugerem, canalizam e promovem a construção de padrões de conduta na ontogênese do sujeito. Esses padrões, por sua vez, regulam campos afetivos da pessoa. Francisco adere a padrões de conduta sugeridos pela Igreja Católica e, com eles, busca regular o próprio sentir. Seus sentimentos em relação aos eventos religiosos, especialmente àqueles dos quais participa, direcionam seu agir no mundo muito em diálogo com sua condição de saúde.

\subsubsection{A experiência no novo instituto de vida consagrada}

Ao ir morar com a irmã, em meados de 2007, Francisco pensa em prestar vestibular, estudar e trabalhar. "Eu me via em outros campos, mas não... a energia não me fazia ir buscar essas coisas". É aprovado em duas faculdades em outros estados, mas não ingressa em nenhuma, visto que a família se posiciona contra sua mudança para um lugar onde não há o apoio de parentes, devido a seus problemas de saúde. No entanto, o grande motor que o afasta da ideia de uma vida profissional fora do sacerdócio é sua percepção sobre a própria vocação:

eu de fato não enxergava outras visões, mas eu me via feliz na igreja. Eu ia pra missa, quando estava na missa, estava aquela coisa ótima, mas quando a missa acabava... sabe quando você foi em uma festa, a festa tá muito boa e você não quer sair de lá, mas você é

obrigado a deixar a festa? É mais ou menos assim. Eu ia pra casa sempre triste... sabe como se te faltasse algo? Como se... não tá completo, não tá bom. (primeira entrevista)

Em 2010, o Francisco se aproxima dos padres da paróquia que frequentava, inclusive aquele responsável pelos encontros vocacionais, partilhando com ele seu desejo de ser religioso. Estabelece uma amizade com esse padre: sempre se encontram; o padre acostuma-se a visitar a casa da irmã do Francisco, onde este residia; eles vão juntos ao cinema, visitam outros jovens vocacionados que residem nas redondezas. E por isso Francisco decide lhe contar sobre sua condição de saúde, convidando o padre para acompanhá-lo a uma consulta médica, com a intenção de informá-lo da sua real situação de saúde antes de começar a participar nos encontros vocacionais: "ele saiu do consultório assim meio assustado. [...] Eu fiquei um pouco apreensivo com a resposta, 'qual será a resposta? Vou ou não vou?' Mas lá no fundo eu achava assim: 'isso não vai dar certo'. [...] Eu tinha esse receio de me decepcionar de novo".

O Francisco é autorizado a participar dos encontros vocacionais em 2011 e aceito para ingressar no postulantado daquele instituto de vida consagrada no início de 2012. Ao ser perguntado sobre as experiências marcantes no postulantado, que durou até o final de 2013, ele 
novamente destaca a sua condição de saúde. Sua narrativa volta a ser construída mediada pelos modos como a doença o posiciona nos contextos.

A convivência... a convivência e ao mesmo tempo... hum, isso é assim, chato, né? A desumanidade. Que assim... é... a convivência, os meninos me ajudavam muito quando eu passava mal, quando eu precisava. Não conseguia passar sonda, então eles precisavam ajudar... mas a desumanidade dos... de um formador, não vou colocar os dois porque não foi a fraternidade toda, foi um. De rejeitar, de criticar, de achar que eu estava perdendo tempo e eles perdendo tempo comigo, então isso... A convivência e a não, digamos, a não sensibilidade. (primeira entrevista)

Essa tensão com um dos formadores perdura por todo o primeiro ano do postulantado. Francisco diz que sofria muito com os comentários do formador, que deixava claro que ele era um "peso" para o restante do grupo. Diz que o dia mais difícil foi uma das vezes que passou mal e precisou ir às pressas para o hospital:

quando eu entro no hospital, [o formador] já entra brigando, eu e ele começamos a discutir, porque ele falou assim: "está vendo que você não tem condições para ficar aqui? Por que você não pede para ir embora?" Aí ele começou a fazer um terror psicológico, e ele é psicólogo. Então aquilo me incomodou muito. Eu falei assim: "será se eu não tenho vocação mesmo?" (primeira entrevista)

Francisco apresenta aqui sua percepção em relação ao formador, provavelmente em diálogo com suas experiências passadas em relação à figura do padre. Em um instituto de vida consagrada, fundamentado nos valores evangélicos, a caridade e o acolhimento do outro são princípios orientadores da ação e da formação. O jovem faz uma dupla crítica ao formador: como padre religioso consagrado e como psicólogo. O sentido que este oferta para a doença do Francisco contradiz aquele ofertado pelo bispo Justino. Ao mesmo tempo, a vivência desse tipo de experiência justifica a resistência do jovem em resignar-se à doença e, ao contrário, desejar tanto a cura. Por mais que pudesse ser interpretada como "cruz", graça de Deus e modo de viver a vocação religiosa, a doença também era uma ameaça real à permanência do jovem na vida religiosa — uma ameaça que ele experimentava na relação com quem tinha autoridade para pedir seu desligamento da instituição (como já havia acontecido).

Ao retornar para casa, após a discussão com o formador, Francisco diz ter começado a admitir a possibilidade de que realmente atrapalhasse o grupo, seus colegas, já que dependia muito deles devido à fragilidade da sua saúde. Influenciado pelo formador, alteraram-se suas disposições semióticas e surgiu uma confusão, da parte dele, entre vocação e disposição de alguns membros da congregação em recebê-lo.

Fiquei uma semana e meia, a gente brinca, em crise [risos]. Mas uma crise mesmo, de ficar isolado no quarto. Descia pra rezar, pra fazer meu trabalho, mas era sozinho, colocava o 
fone de ouvido e ia ouvir algumas músicas que me ajudavam, fazia o que era minha obrigação, voltava pro quarto. Hora de estudo, sentava na minha mesinha, falava o essencial com os meninos. Na hora do almoço sentava também, conversava o essencial e mais no quarto [grifos do pesquisador]. (primeira entrevista)

A esse isolamento, a essa "crise", Francisco chama de "noite escura", fazendo referência ao poema de São João da Cruz que narra a jornada da alma desde a sua morada terrena até a união com Deus. São João da Cruz chama essa jornada de "noite escura" associando a escuridão às dificuldades que a alma encontra em desapegar-se do mundo e chegar à união com Deus. A dolorosa experiência vivenciada nessa busca de crescimento espiritual e de união com Deus é a ideia central do poema, com a qual Francisco busca se identificar. O jovem utiliza o poema como recurso simbólico (conceito explorado à luz do caso Fátima) num esforço para manter seu sentido de continuidade.

$\mathrm{Na}$ superação de rupturas, o sujeito se utiliza de recursos simbólicos que orientam e direcionam processos de transição de desenvolvimento. Isso favorece, de certa maneira, a mudança pessoal dada a emergência de novos posicionamentos sociais, bem como a elaboração das emoções, direcionando novos modos de ser, sentir e interpretar o mundo (Zittoun, 2006, 2007).

No final de 2013, o Francisco ingressa no noviciado, em outra cidade e com outros formadores. Esse tempo the proporciona, segundo disse, maior intensidade no contato consigo mesmo e na oração. "O noviciado, com que se inicia a vida no instituto, destina-se a que os noviços conheçam mais profundamente a vocação" (CDC, cânone 646). Dois rituais são marcantes no período do noviciado: o primeiro é o recebimento da vestimenta que caracteriza os membros daquela instituição, o hábito, logo que se ingressa no noviciado (o que acontece também no caso Cecília); o segundo é a primeira profissão, os votos simples e temporários, de pobreza, castidade e obediência, celebrada no final do noviciado (o que acontece com os quatro participantes).

Na primeira entrevista, Francisco estava usando o hábito religioso e, como já informado, em poucos dias realizaria sua primeira profissão. A experiência de receber o hábito, símbolo visível da identidade da instituição, é marcante para Francisco:

receber o hábito... eu já pertenço a... ele, além de me dar esse pesinho na ordenação, me dá estabilidade... agora pra ser mandado embora é mais difícil [sorri]. É uma segurança o hábito, é uma segurança no sentido assim: pertenço a esta [instituição]. Me dá uma segurança e me dá uma identidade... é visível pros outros... [grifos do pesquisador]. (primeira entrevista)

Francisco desenvolve um sentido singular de pertença mediado pelo objeto significativo hábito. E esse sentido dialoga com sua condição de saúde. Se por um lado o hábito lhe oferece uma identidade religiosa, possível de ser vista pelos outros, um significado objetivado do ser religioso, 
por outro, com seus significados culturais, seu "poder" semiótico de despertar sentimentos, é símbolo particular de segurança para o jovem.

Segundo o Código de Direito Canônico, o noviciado é a entrada do jovem na vida religiosa, é uma transição do ser leigo para o ser consagrado. $\mathrm{O}$ hábito religioso reforça tal sentido à medida que iguala o jovem não professo, visualmente, ao religioso professo. Ao comentar as expectativas em relação a sua primeira profissão, o Francisco também apresenta uma significação do rito orientado pela condição de saúde:

primeiro, me dá estabilidade. Segundo, agora eu sou da [instituição]. A gente brinca: meu nome vai estar lá, de lápis, mas vai estar lá na casa geral, lá em Roma! [...] E terceiro, [...] não será só um simples falar, uma simples forma, mas aquilo que eu já comecei a viver e agora eu falo assim: "eu quero, eu quis e creio e é isso que eu vou fazer". E é ver que tudo aquilo que eu sonhei, tudo aquilo que eu construí, começa a se realizar nos meus votos. [...] A minha consagração primeiro é pra Deus, pra Cristo. E na minha resposta, na minha consagração pra Cristo, aí sim. Aí eu quero tentar ser, nem que seja um pouquinho melhor do que eu sou, ser menos mesquinho, ser menos... não pra me vangloriar, não pra isso. Mas pra tentar fazer a vida do outro um pouco mais suportável, um pouco mais agradável, um pouco mais... para devolver ao outro a dignidade... Porque assim como eu, às vezes, perdi minha dignidade como pessoa, vejo que a minha consagração pode me ajudar a devolver e a levar dignidade ao outro... eu cuidar dele e também deixar ser dependente. Porque uma coisa que eu trago muito é que eu não gosto de ser dependente do outro, sou meio orgulhoso na minha saúde [grifos do pesquisador]. (primeira entrevista)

As continuidades e mudanças esperadas pelo Francisco com o evento da consagração estão muito em diálogo com a performance sugerida pelo bispo Justino. O jovem aposta na sua consagração como rito de passagem para uma possível resignação em relação à doença: "minha consagração pode me ajudar" a concretizar os sonhos, ser uma pessoa melhor, ajudar os outros, ser menos orgulhoso, não sofrer com a dependência do outro. Isso destaca a tensão entre aceitar e rejeitar a doença como modo de experienciar a vocação religiosa. Até aquele momento, o jovem claramente não aceitava a doença como graça de Deus, por isso, orientado por significados institucionais referentes à profissão dos votos, busca criar sentidos que o apoiem neste novo modo de viver a vocação.

Ele destaca algo que aparece igualmente na fala de outros participantes: a significação da profissão dos votos como reafirmação pública de algo que era vivenciado antes. De certa forma, os vocacionados à vida religiosa, ao ingressarem em um instituto de vida consagrada, já começam a viver os votos religiosos, antes mesmo de se tornarem professos.

De qualquer forma, o rito de passagem institucional denominado primeira profissão sugere novos modos de ser e de sentir ao jovem, ao mesmo tempo que o reposiciona diante dos outros 
membros da instituição, da própria Igreja e das pessoas leigas. Nesse momento, percebido como ruptura, Francisco aposta para que, ao assumir o sentido institucional da profissão dos votos, consiga agir de modo mais próximo aos valores daquele contexto. Aqui também os sentidos sobre sua condição de saúde dialogam com as novas possibilidades de ser e de se sentir religioso consagrado. O jovem quer ser instrumento de dignificação do outro, talvez por ter sentido, várias vezes, que perdia a dignidade quando dependia do outro, ou quando o outro o desprezava por sua condição de saúde. Ao mesmo tempo, deseja se entregar mais aos cuidados dos outros, aceitar suas limitações como pessoa doente. Isso ajudaria a resolver o problema destacado pelo bispo: "o seu problema está em não assumir, em não aceitar sua cruz. E quando você assumir, aceitar sua cruz, você vai conseguir aquilo que você quer. [...] Não está na sua doença, [...] o problema está em você não aceitar aquilo que você tem, a sua limitação".

\subsubsection{A vivência da vocação como professo simples}

Ao ser entrevistado pela segunda vez, o Francisco já tinha quase 14 meses na condição de professo temporário, portanto, já havia renovado os votos uma vez, pois a profissão simples é válida por apenas um ano. O jovem também estava finalizando seu segundo semestre no curso de filosofia. Em nossa conversa, ganhou destaque o ser religioso consagrado, com votos temporários, e o ser universitário, aluno do curso de filosofia, compartilhando o espaço da sala de aula com outros seminaristas, pessoas leigas e, inclusive, pessoas que diziam não acreditar em Deus ou não tinham religião.

Tanto a profissão dos votos como o ingresso no curso superior foram reposicionamentos identitários que exigiram do jovem novas configurações e ajustes no sistema de self. Novos modos de se ver, ser visto e sentir o mundo foram possibilitados, criando conflitos e tensões dialógicas:

quando eu fiz a primeira profissão, falava assim: "o que que mudou?" Eu falei assim: "fisicamente nada [risos]. Fisicamente nada". Mas é diferente. A responsabilidade é maior. Antes eu não tinha os votos. Eu poderia me valer da questão: "ah, eu não tenho os meus votos ainda!" Hoje eu tenho consciência: foi eu que quis. Eu falei: "eu... então, eu quis. Ninguém me obrigou”. Agora a responsabilidade é minha. É maior. É dessa forma que eu encaro, hoje, a minha profissão. Deus não me obrigou. Eu que me obrigo agora a viver aquilo que eu me dispus. Então, isso me é caro, nesse sentido. Será que eu estou vivendo uma consagração? Será que eu estou sendo fiel? Ou não? Hoje o meu ser professo é isso. [...] Eu acho que eu sou um outro Francisco nesse sentido. O que me fez mudar o jeito de ver vocação é... eu sempre via vocação no sentido de futuro... opa, espera aí. Eu já fiz os 
votos, eu ainda não cheguei a ser padre, mas eu já sou professo. [...] A minha consagração não foi pra mim. Eu não me consagrei por status. É a minha resposta àquilo que Deus me deu. O que Deus me deu, como eu respondo? Se Deus me deu a vida, como eu respondo à vida que ele me deu? Então vocação, pra mim, é o meu sim diário [grifos do pesquisador] (segunda entrevista)

Francisco apresenta elementos simbólicos e posturas que indicam novos posicionamentos perante a vivência da própria vocação. E esses elementos são (re)significados em diálogo com um sentido de continuidade de si, mediado pela condição de professo simples. Portanto, o sujeito cria modos de ser e de sentir, no presente, ancorados nas experiências do passado e impulsionados pelas expectativas. Com isso, novos signos emergem no fluxo da experiência, regulando o presente e assumindo papel importante na antecipação do tempo futuro, orientando expectativas e modos de sentir situações similares (Valsiner, 2014). Nesse movimento dialógico, sistemas semióticos construídos na experiência vivida podem ser retomados e ressignificados.

Antes de professar os votos o Francisco, assim como os outros participantes, vivia a pobreza, a castidade e a obediência na busca de uma adequação às normas institucionais. A experiência como não professo antecipava a vivência de um futuro como professo simples. Se antes era um ajustamento entre pessoa e instituição, agora passou a ser uma escolha, uma responsabilidade.

Visto ter sido ele quem pediu, no dia da sua profissão, para ser aceito na congregação como religioso consagrado, isso configura para ele agora uma escolha pessoal, que the é cara. Por isso, novas tensões dialógicas são vividas nas esferas de experiência (por exemplo, convento e universidade) e entre elas. Como estou vivendo esse compromisso pessoal? "Será que eu estou sendo fiel?" Antes essa preocupação não afigurava como importante, pois o jovem não tinha professado os votos; no entanto, após o rito institucional, novos sentimentos são despertados em relação à vivência da vocação.

Reposicionamentos sociais e institucionais levam o jovem a sentir-se um "outro Francisco", mudanças que ele sintetiza no modo inédito de viver a vocação religiosa: no aqui e agora, e não no futuro. Na primeira entrevista, ele apresenta expectativas em relação à profissão dos votos: sentir-se mais estabilizado na instituição, ser uma pessoa melhor, aceitar mais a ajuda do outro, proporcionar experiências de dignidade ao outro. Já na segunda entrevista, numa postura de releitura de si, ele parece querer ser no presente e não no futuro: "é nesse conflito que eu tento organizar minha vida religiosa. Que religioso eu estou sendo?"

Ao ser questionado sobre a preocupação com a estabilidade na instituição religiosa, garantida pela profissão dos votos, ele responde:

continuo com as mesmas neuras, com os mesmos medos nesse sentido. Mas é tão mais... sei lá! Eu acho que... talvez eu não conte mais tanto com essa possibilidade! [...] Eu já 
gastei tanta energia com essa preocupação que eu falei: "não, espera aí, deixa eu respirar um pouco, deixa eu..." então eu já gastei muita energia com isso. Com os outros querer me mandar embora. "Não, se quer me mandar embora, que ache argumentos, que prove alguma coisa", entendeu? Já cansei de me auto, me autodefender, de ficar sempre na defensiva. Não, estou cansado. Cansei disso! (segunda entrevista)

A reorganização no sistema de self do Francisco indica novas relações dialógicas no complexo semiótico relacionado ao ser padre. O sentido de vocação, antes vivido muito em função de uma possibilidade de futuro, toma outra orientação: agora, é percebido como realidade presente. "Espera aí. Eu já fiz os votos, eu ainda não cheguei a ser padre, mas eu já sou professo" — o medo de ser mandado embora e assim não realizar o sonho de ser padre ainda existe, porém, em diálogo com o novo modo de ser vocacionado, orienta e é orientado por outros elementos do complexo semiótico de maneira aparentemente inédita.

Num tempo passado, antes da profissão dos votos, o medo de não ser padre estava diretamente relacionado à possibilidade de ser mandado embora por causa da condição de saúde. Nesse sentido, a profissão religiosa poderia oferecer maior conforto ao jovem, que acreditava que, quanto mais avançasse na formação religiosa, menos chance teria de ser mandado embora. Contudo, esse aparente conforto advindo da profissão dos votos parece ter dado espaço para outra preocupação, que, mesmo aparentemente já existindo, não era destacada:

Pesquisador: Francisco, e os receios, os medos de hoje? Quais são?

Francisco: Os receios de hoje? O não ser padre ainda persiste. Não o ser mandado embora, mas o não ser padre ainda persiste.

Pesquisador: Por qualquer motivo que seja?

Francisco: Isso, independente do que seja! Seja físico ou seja... eu brinco: "senhor, o senhor pode me levar, mas aí o senhor vai escutar muita coisa quando chegar aí! [risos] Depois que eu rezar a minha primeira missa, se o senhor quiser me levar, pode me levar, mas me deixa antes rezar uma missa. Então assim, o receio de não ser padre, não ser aquilo que eu quero ser.

O medo de não se ordenar padre continua, contudo orientado por outros significados. A condição de saúde em si assusta mais do que a possibilidade de ser mandado embora da instituição. A experimentação de ritos de passagem, como ser aceito no postulantado, ingressar no noviciado, receber o hábito e professar os votos, pode levar o Francisco a sentir maior estabilidade em relação à sua permanência na congregação, mas não elimina a ameaça que a doença provoca à possibilidade de ele vir a ser padre. Assim, numa reorganização do complexo semiótico relacionado ao ser padre, novas relações dialógicas são estabelecidas entre os elementos. As transições desenvolvimentais na trajetória de vida do jovem resultam na criação de novas hierarquias de significados, reorientando modos de ser e de sentir a tensão vivida na fronteira 
semiótica que separa, ao mesmo tempo que une, o estar dentro e estar fora da vida religiosa consagrada.

Nessa nova reorganização hierárquica dos complexos semióticos, o ambiente universitário, bem como as leituras e reflexões possibilitadas pelo curso de filosofia, parece ter importante papel: talvez eu vou encontrar alguns ou um Francisco. No sentido, assim, que da primeira entrevista pra hoje, algumas coisas mudaram. Amadureci em algumas coisas, é... me apeguei mais em algumas outras, no sentido de achar que tem algum valor e aí eu trago pra mim. Eu brinco, até brinquei esses dias lá em casa: hoje eu posso dizer que mudou, mas continua a mesma coisa [risos]. Não nesse sentido de mudança radical. No sentido do conversar, do ver o mundo de outra forma. Isso a filosofia me trouxe uma vantagem nesse sentido. Filósofo é chato, questiona tudo, né? Isso eu peguei da filosofia. Então, nessa visão, um outro Francisco, nesse sentido. Ser mais crítico. Eu já era crítico. Aguçou mais meu ser crítico. Algumas coisas que pra mim eram valores eu deixei por um tempo. Hoje eu trago de volta, eu retomo de volta: que é a hospitalidade, a dinamicidade. Eu deixei, durante um tempo passei a ser mais estúpido, mais grosso. Eu trago isso de volta. Estou tentando ser menos estúpido, menos grosso. Então, essas coisas que eram mais minhas e que eu fui deixando, por achar que não precisava mais, sei lá, fui deixando. Então hoje, nesse ponto... e a vida religiosa me ajudou muito nisso [grifos do pesquisador]. (segunda entrevista)

Francisco realiza sínteses de experiências vividas e imaginadas em diferentes esferas, concretizando nessas sínteses o fluxo do tempo: presente, passado e futuro. $\mathrm{O}$ reposicionamento social e institucional (ser religioso consagrado, ser universitário, estudante de filosofia), de modo singular, possibilita relações dialógicas entre expectativas futuras, canalizações contextuais do presente e sistemas semióticos construídos na experiência passada, que são retomados no presente como modo de ressignificação e construção do sentido de continuidade de si. A filosofia coloca o Francisco na posição de questionador e crítico, o que aparentemente contribui para uma releitura do que realmente era valor para ele. Assim, o jovem coloca em questão a própria hierarquia de valores e, nesse processo de reflexão, o medo de ser mandado embora é reavaliado. Ele perde espaço para algo que é visto como mais importante, a vida.

Diferente do que parece acontecer com parte dos estudantes que ingressam em um curso superior, considerando expectativas sociais, o Francisco não foca suas reorganizações hierárquicas de significados na reelaboração de projetos em diálogo com uma carreira profissional (Camarano, Mello, \& Kanso, 2006; Macmillan, 2006). O jovem coloca em diálogo significados sugeridos no contexto universitário com a esfera de experiência "vida religiosa". E nesse sentido a filosofia contribui no disparo de questionamentos sobre o eu e sobre o outro. Há um novo olhar da vida religiosa que é fruto de variadas experiências, é um conjunto de tudo: "é a filosofia, a casa, a minha 
disponibilidade, meus questionamentos, meus retiros pessoais. É tudo um conjunto. São as minhas formações. Tudo é um conjunto que me leva a ver a vida religiosa nesse sentido hoje".

Ao nos aproximarmos do término da segunda entrevista presencial, solicitei ao Francisco que pintasse mentalmente quatro quadrinhos que representavam sua trajetória de vida. Em torno de três minutos depois, pedi que ele me relatasse o que selecionou para cada quadrinho. Para o primeiro, ele havia imaginado a cruz de Cristo; para o segundo, a representação de uma festa de aniversário; para o terceiro, um grupo de pessoas; e, no quarto quadrinho, ele disse que colocaria um ponto de interrogação.

Com exceção do terceiro quadrinho, os outros três apresentavam ligação direta com sua condição de saúde. "Contemplar a cruz. Ver o Cristo abandonado. Aquilo que ele fez por mim... porque, se ele passou por isso, por que que eu me dou o prazer de achar que eu não devo passar?" O jovem novamente sugere uma tentativa de resignação à sua condição de saúde, uma tensão colore a forma como ele vivencia sua vocação religiosa. Isso indica que o conflito entre aceitar a doença como modo de experienciar a vocação e desejar a cura, rejeitar a doença como dom de Deus, ainda persiste e orienta relações no complexo semiótico relacionado ao ser padre. Nesse sentido, a performance sugerida pelo bispo Justino, apesar de ser admirada e estar em harmonia com um sentido cristão de sofrimento como graça, ainda encontra resistência no jovem - que, porém, não a abandona totalmente.

A festa de aniversário, segundo o Francisco, representava a sua vida festejada pela sua mãe. Ele contou que sua mãe sempre comemorou seu aniversário, mesmo que de forma muito simples. "Aí ela comprou um sanduíche pra mim, comprou fiado, e a dona do pit-dog ofereceu um refrigerante. E era meu aniversário. E era só eu e ela. Minhas outras duas irmãs não foram.” De certa forma, o Francisco busca na postura da mãe, que quase o perdeu por várias vezes, uma justificativa para aceitar a própria condição. "Eu reli... hoje é outra coisa pra mim. Ela fazer isso pra mim... hoje foi... por isso a festa. Minha mãe sempre festejou minha vida". A postura da mãe o faz questionar o modo como ele próprio tem encarado a doença: “quantas vezes eu falei: 'ai, meu Deus, por que que o senhor me fez? Por que que eu nasci' Quantas vezes questionei isso. Quantas vezes me deparo, às vezes questionando nesse sentido?"

O terceiro quadrinho representa pessoas que ele considera importantes na sua caminhada vocacional: sua família, especialmente sua avó, bem como amigos padres e colegas seminaristas que sempre o incentivaram a persistir na vida religiosa. Por fim, no quarto quadrinho, o ponto de interrogação representa sua insegurança em relação ao futuro; em outras palavras, seu medo de não chegar a ser padre. Naquele momento, o medo estava muito mais relacionado a sua condição de saúde do que ao seu receio de ser mandado embora: "é essa dúvida... no sentido assim... eu vou conseguir ser aquilo que eu pretendo? Ou eu vou perder aquilo que eu não quero perder? O que vai 
se dar? [...] É esse medo... Não o medo do futuro, mas a dúvida: o Francisco vai chegar lá? [...] Vou conseguir ser padre?"

Em setembro de 2016, o Francisco me enviou uma mensagem informando que havia sido mandado embora da instituição devido ao seu problema de saúde. Perguntei como ele estava e se iria retornar para a sua cidade natal. Ele disse que ainda não sabia, iria terminar o semestre do curso de filosofia e depois decidiria. Afirmou estar muito triste e decepcionado.

\subsection{Caso Vicente: a organização do sistema de self a partir do diálogo com projetos em aberto}

\subsubsection{Momentos de entrevista e construção de informações}

O Vicente foi um dos jovens indicados por um colega. Nós já havíamos nos comunicado via e-mail e telefone para negociar a primeira entrevista e ele havia respondido ao Guia de Evocação de Narrativas Escritas, enviando-o por e-mail para mim.

O primeiro encontro presencial com o Vicente se deu em 3 de setembro de 2014, no convento onde ele morava. Na oportunidade, expliquei os objetivos do estudo e solicitei a assinatura do TCLE. Apresentei a metodologia do estudo, ressaltando os possíveis encontros que teríamos pela frente. E, naquele mesmo dia, realizamos a primeira entrevista, do tipo história de vida.

$\mathrm{Na}$ época, o Vicente estava com 21 anos. Tendo ingressado na instituição com 16, em 2010, aquele era o seu quinto ano de formação religiosa. Conversamos sobre a história da sua vocação para a vida religiosa, abordando questões relacionadas à família, à infância, à adolescência, aos estudos, ao trabalho, bem como ao contexto da instituição religiosa e às perspectivas futuras.

Também com o Vicente foi possível mantar contato no intervalo entre as entrevistas presenciais. Comunicávamo-nos via whatsapp, telefone e Skype. Inclusive, em fevereiro de 2015, em uma conversa por Skype, falamos sobre o término do curso de filosofia, ocorrido em 2014, o ingresso no noviciado, em janeiro de 2015, a mudança de formador e de cidade e suas perspectivas em relação à preparação para a profisssão simples, no final do ano de noviciado.

Em 30 de janeiro de 2016, voltei a encontrar-me com o Vicente para realizarmos outra entrevista presencial, nas dependências de uma faculdade confessional, onde o jovem iniciaria, em fevereiro daquele ano, o curso de teologia (roteiro utilizado em anexo IX). Aquela era a quarta cidade em que o jovem residia desde o seu ingresso na instituição religiosa. 
Aquele segundo momento de entrevista presencial ocorreu uma semana após a celebração na qual Vicente professou publicamente os votos religiosos (pobreza, castidade e obediência), portanto, oito dias após o término do seu noviciado. Conversamos sobre as experiências vividas no noviciado; o significado pessoal e institucional dos votos; as mudanças esperadas e ocorridas após a profissão simples, quando ele passou a ser reconhecido pela Igreja e pela comunidade como religioso consagrado; suas perspectivas e o processo de decisão de não se ordenar padre, continuando como irmão leigo consagrado.

\subsubsection{Caracterização do caso}

Vicente iniciou seus estudos aos 7 anos e, aos 9, ingressou na catequese. Até os 10 anos, morou na zona rural de uma pequena cidade com os pais e duas irmãs, sendo ele o segundo filho. A família se mudou para a cidade quando adquiriu a casa própria. Desde seu ingresso na catequese, o Vicente esteve muito envolvido nas atividades da igreja, especialmente após ser coroinha, aos 11 anos, quando passou a ajudar nas celebrações de missas tanto na sua cidade como na cidade da sua avó, onde geralmente passava as férias escolares. Segundo o jovem, a constante participação no ambiente da igreja proporcionou uma aproximação e conhecimento do modo de vida dos padres. Nesse período, ele começou a cogitar a ideia de ser padre no futuro.

Aos 14 anos, incentivado pelo pai, ingressou na guarda mirim da sua cidade, um projeto social coordenado por ex-militares, fundamentado nos valores das instituições militares. Cerca de um ano antes, um de seus primos havia ingressado nas forças armadas, fato que contribuiu, segundo o Vicente, para que sua família e ele próprio criassem uma expectativa de carreira nas forças armadas. Desde então, o garoto diz ter vivido a dúvida entre ser militar e ser padre.

Contrariando as expectativas da família, especialmente as do pai, em 2009, aos 15 anos, o Vicente abandonou o projeto da guarda mirim e decidiu focar seus estudos do ensino médio na área das humanidades, considerando a possibilidade de ser aceito no seminário no ano seguinte. Em 2010, ingressou na instituição religiosa, mudando-se de cidade. Ali realizou a primeira etapa de formação religiosa, o postulantado, ao mesmo tempo que cursou o terceiro ano do ensino médio.

Em 2011, o Vicente mudou-se novamente de cidade e iniciou o curso de filosofia, o qual foi finalizado em 2014, quando o jovem havia retornado para a cidade onde iniciou a formação religiosa. Foi nessa época que ele participou da primeira entrevista neste estudo. No ano seguinte, 2015, o Vicente vivenciou a experiência do noviciado morando no estado de São Paulo. Em 2016, época da nossa segunda entrevista presencial, ela já havia professado os votos religiosos, atendia 
pelo título de irmão Vicente e iniciaria, nos próximos dias, seus estudos no curso de teologia em uma capital.

\subsubsection{Movimentos semióticos e tensões dialógicas na trajetória de vida do Vicente}

Os movimentos de construção e reconstrução do sistema de self ao longo da trajetória de desenvolvimento são processos de emergência de novos modos de ser e de sentir do sujeito. Constantemente e de modo dinâmico, a pessoa cria significados, ou modifica antigos, ao lidar com as situações inéditas do cotidiano, o que permite e canaliza um modo de dialogar com o mundo. Nesse sentido, o passado, o presente e o futuro são momentos inseparáveis de um mesmo tempo. A fronteira do presente que separa o futuro (o ainda não conhecido) do passado (o já conhecido) é um campo real e simbólico onde emergem o próximo presente e a novidade na interpretação do passado vivido e do futuro imaginado. "O presente é o local de nascimento do próximo instante presente" (Valsiner, 2012, p. 112), assim como de novos sentidos do passado.

$\mathrm{Na}$ construção de informações referentes ao caso Vicente, o futuro, como elemento em aberto, mostrou-se fundamental na organização e orientação do momento presente do jovem. Ele, como os demais participantes, narrou a sua trajetória vocacional, buscando levar o interlocutor a compreender a razão de ser, naquele momento presente, um jovem em formação para a vida religiosa consagrada. Porém, de modo bem mais acentuado que os outros participantes, suas narrativas destacaram uma integração entre presente e possibilidades de ação no futuro, em que o futuro, tomado como espaço-tempo em aberto e horizonte semiótico em construção, constantemente era reivindicado na resolução de tensões vividas no presente e na criação de sentidos de continuidade de si.

Eu acho que os projetos devem ser muito em aberto. Se a gente fecha muito, tá muito mecânico, né? [...] O projeto tem que ser aberto. Já tenho essa visão. Pra você não ficar muito perdido, deve ter, assim, um itinerário, mas projetos em aberto. [...] Depois dos votos, não sei o que vai acontecer, mas enfim, deixar projetos em aberto. [...] Crise de modo geral, crise vocacional, crise humana, se você age... é não ficar parado, né? Se você age na crise... o melhor caminho é o caminho que você escolhe. Eu acho isso. É o caminho que você escolhe. Muitas pessoas podem falar o contrário [grifos do pesquisador]. (primeira entrevista)

A seguir, apresento e analiso resultados do caso Vicente tomando como caminho interpretativo a ênfase dada pelo jovem ao diálogo entre presente e possibilidades de ação no futuro como projetos em aberto. Nesse sentido, tomam destaque na discussão momentos de bifurcação em 
diálogo com futuros imaginados, que orientam e organizam o sistema de self do jovem. São momentos de escolhas que exigiram resistência ao presente e reorganizações no sistema, possibilitando, assim, a emergência de novos complexos semióticos, novos posicionamentos e conceitos de si e novas perspectivas, sempre projetados num futuro probabilístico.

\subsubsection{Ser padre ou ser militar}

A cultura sugere significados que, implícita ou explicitamente, orientam e solicitam comportamentos do sujeito na consideração de uma determinada hierarquia de valores. Ao ingressar na esfera de experiência da igreja, principalmente como catequisando e depois como coroinha, o Vicente passa a vivenciar repetidas experiências que sugerem modos bem específicos de ser, agir e sentir no mundo. Da mesma forma, mais tarde, o contexto do projeto guarda mirim reforçaria comportamentos e modos de ler o mundo que também passaram a integrar o sistema de self do garoto. A participação nessas duas esferas de experiência contribuiu para que o Vicente vislumbrasse duas trajetórias no futuro: ser padre ou ser militar.

E o padre: "pode ser que esse rapazinho aqui tão sério, tão quietinho, pode ser um padre. Você não quer ser padre?" Na frente de todo mundo! Se eu desse uma resposta negativa era vergonhoso! Aí eu: "quero, eu quero ser padre”. Nem sabia o que era ser padre, tinha 6, 7 anos. [...] E ficou padre na minha cabeça, eu quero ser padre. Porque o padre está com o microfone, está bonitinho lá, todo mundo respeita o padre aqui... achei interessante, todo mundo respeitava o padre. [...] A figura pra mim central era o padre! [...] Então foquei nele.

[...] Essa pergunta foi cruel na quinta série pra mim: "o que você quer ser quando crescer?" Olha, meu pai sempre foi corajoso, trabalhava como leiteiro, mas eu não queria trabalhar como leiteiro também. [...] Quero ser uma coisa diferente. Não quero ser como os outros! Minha "crise" aí, entre aspas, era: respeito o meu pai, amo muito o trabalho dele, mas eu não queria ser leiteiro. [...] Eu realmente queria ser uma coisa diferente, [...] mas também não queria falar o que os outros já tinham falado. [...] Aí eu lembrei que todo mundo respeitava o padre, o padre falou que eu ia ser padre, eu falei talvez sem refletir muito: "vou ser padre".

[...] Na catequese, meu catequista foi pro seminário. [...] Isso me ajudou muito. [...] Primeiro porque era... era não, é um rapaz muito inteligente, né? [...] Eu tinha orgulho. Tenho orgulho dele ter sido meu catequista. Falava muito bem, era celebrante, estava na comunidade! Foi pro seminário: eu também vou! Falava sem saber de nada: eu também vou! [grifos do pesquisador]. (primeira entrevista) 
Ao buscar esclarecer a emergência do seu desejo de ser padre, o Vicente recorre a um primeiro momento de bifurcação importante na organização do seu sistema de self. Ele lembra as primeiras situações nas quais a possibilidade de ser padre foi sugerida na sua vida. Ainda antes de Vicente iniciar a catequese e de ser coroinha, em um casamento, o padre explicava aos fiéis o significado de vocação, afirmando que a vocação é um mistério que muitos de nós desconhecemos. Ao se aproximar do menino, na época com 7 anos, o sacerdote disse que ele poderia ser um padre quando adulto. Terminou o comentário perguntando ao próprio Vicente se ele gostaria de ser padre. A tal pergunta, o garoto respondeu de modo afirmativo, segundo ele por imaginar que não poderia responder negativamente, sendo o padre uma pessoa tão importante na comunidade. Desde então, muitas pessoas da comunidade começaram a chamá-lo de "padrinho" (diminutivo de padre).

Quase três anos depois, em outra situação, ao ser questionado pela professora sobre o que gostaria de ser quando crescesse, Vicente, motivado pelo desejo de ser diferente, de não repetir o que seus colegas haviam respondido, disse que iria ser padre: "aí eu lembrei que todo mundo respeitava o padre, o padre falou que eu ia ser padre, eu falei talvez sem refletir muito: 'vou ser padre",.

Na primeira situação, o Vicente concorda com o sacerdote, afirmando que queria ser um padre, para não contradizer a fala daquela autoridade respeitada no seu contexto cultural. Na segunda situação, o garoto novamente leva em consideração o respeito pela figura do padre, mas também apresenta uma interpretação da pergunta do sacerdote quase como um convite e uma legitimação da possibilidade de ser padre ("o padre falou que eu ia ser padre"). Como sugestão social, uma hierarquia de valores relacionados à figura do sacerdote e a questões religiosas é ressignificada pelo garoto, mediante processos de internalização e subjetivação. E a possibilidade de vir a ser um padre agrega valor à pessoa do Vicente já no presente, reservando um espaço diferente para ele na comunidade.

Ser padre passa a funcionar como um campo semiótico circunscrito, onde são colocados em diálogo significados socialmente sugeridos com variada carga emocional. Esses significados são construídos e fundamentados em relações inter e intrapsicológicas nos diferentes contextos de participação do garoto: 
Figura 4. Complexo semiótico relacionado ao ser padre

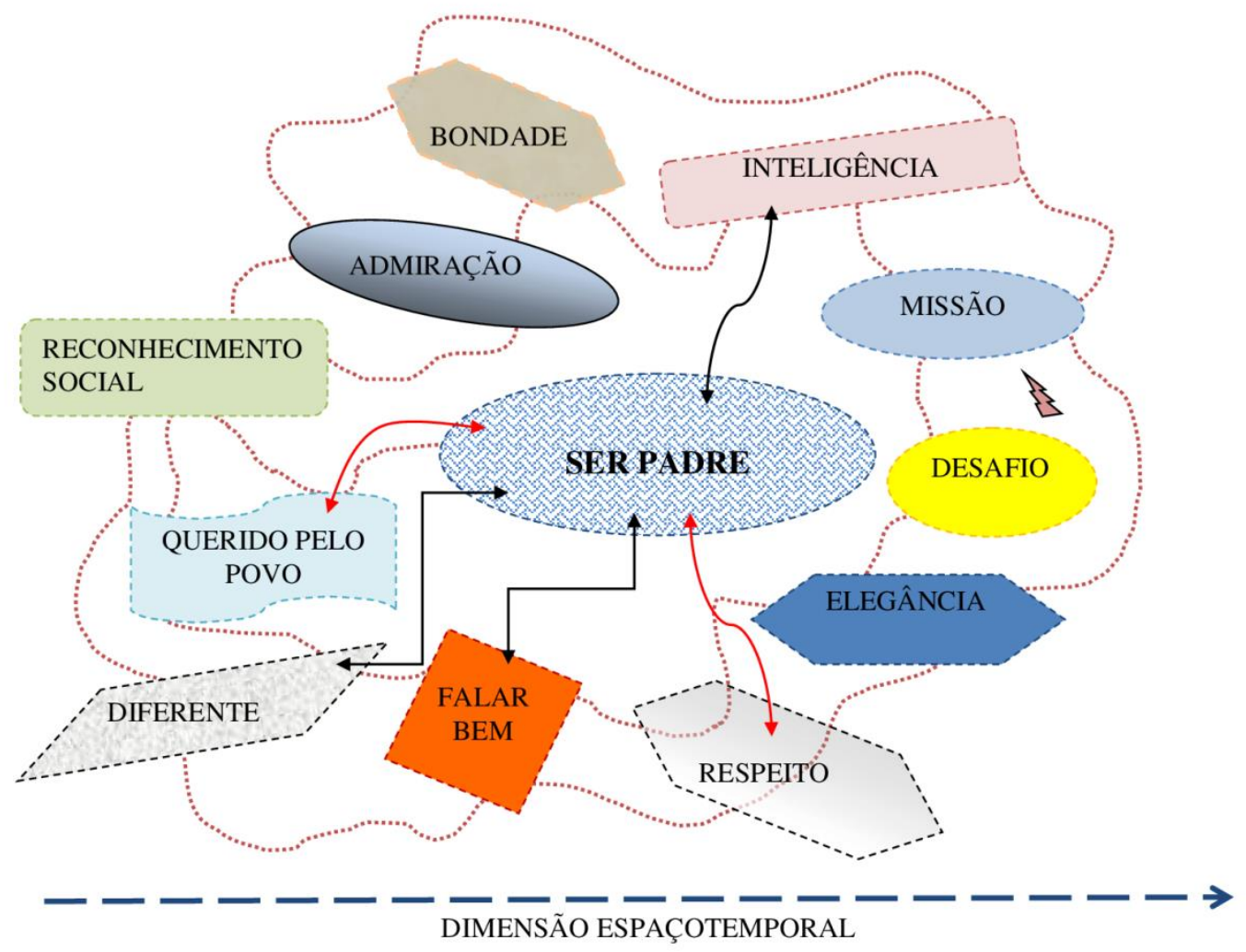

Fonte: Elaboração do pesquisador

Um importante campo semiótico circunscrito, funcionando como um complexo semiótico, coordenado pelo sentido de ser padre, passa a canalizar modos de ser e de sentir do Vicente. Orienta atitudes e escolhas em diferentes esferas de experiência (trabalho, família, escola, igreja, guarda mirim, instituição religiosa) e em diferentes momentos da trajetória de desenvolvimento do jovem. Esse complexo semiótico se transforma, num tempo irreversível, a partir de relações dialógicas com novas esferas de experiência e com futuros imaginados num horizonte de projeção do self.

O Vicente constrói hierarquias reguladoras a partir de dois processos dialógicos: generalização em direção à abstração e especificação em direção ao contexto. $\mathrm{O}$ primeiro processo possibilita a emergência de novos níveis de regulação e orientação semiótica (Valsiner, 2012). E, assim, signos hipergeneralizados coordenam níveis mais baixos de generalização. Os valores sugeridos socialmente e organizados hierarquicamente pelo sujeito em complexos semióticos são exemplos de generalizações do tipo abstrato (Branco, 2015). Por outro lado, o segundo processo consiste na orientação que as generalizações do tipo abstrato operam nos modos de agir, interpretar e sentir nos contextos de atuação do sujeito. 
Vir a ser padre é um signo que ocupa um espaço semiótico hipergeneralizado no sistema de self do Vicente e agrega significados construídos pelo garoto a partir de relações sociais em espaços diversos. Considerando a escalada de abstração do sentimento para a hipergeneralização, ou seja, os processos de emergência e desenvolvimento de signos segundo uma generalização em direção à abstração (Valsiner, 2012), percebemos que, no fluxo da experiência imediata, Vicente experimenta momentos significativos, inicialmente, no nível fisiológico. Em diferentes contextos, ele vivencia experiências que parecem contribuir na construção do sentido pessoal de ser padre.

A figura pra mim central era o padre! [...] Talvez porque ele tenha dialogado comigo, né? Oh, importante o cara que está com o microfone falar com alguém que está na assembleia, só eu... falou comigo, eu sou importante também, né? Então foquei nele. [...] O povo já me chamava de padre: "ó o padrinho". E [...] olhar muito pro padre, achava muito elegante.

[...] Na catequese, meu catequista foi pro seminário. [...] Isso me ajudou muito. [...] Primeiro porque era... era não, é um rapaz muito inteligente, né? [...] Eu tinha orgulho [grifos do pesquisador].

Aos 10 anos, o Vicente assume o cargo de coroinha na igreja. Estava terminando a catequese, espaço onde nutria uma admiração pelo seu catequista. Falar bem, ser inteligente, ser elegante, ter reconhecimento social são aspectos valorizados pelo Vicente, que o levam a admirar o padre e o catequista. Em vários momentos das entrevistas, o Vicente se define como um bom orador e desenvolve sua linha de raciocínio de modo a apresentar ao interlocutor uma organização cronológica e lógica da sua narrativa. Tal preocupação demonstra a permanência de alguns signos como marcadores de uma continuidade no sistema de self do jovem.

$\mathrm{O}$ adolescente, aos 14 anos, já cogitando a possibilidade de ser padre, ingressou na guarda mirim. Ao sugerir novos modos de ser e de sentir, uma nova esfera de experiência reforçou sentimentos já vivenciados no contexto da igreja, tais como formalidade no falar e no agir, um modo específico de se vestir, diferente da maioria, o reconhecimento social, um posicionamento de destaque.

E eu fui pra guarda mirim. [...] Fardado de militar, né? Todo de marrom, coturno, boina... e amava isso. [...] E me deu uma crise, porque meu primo estava na aeronáutica, [...] cresceu como sargento. Fez escola lá. [...] Meu superior foi sargento, foi sargento da marinha. [...] E tinha muito de dizer isso: "não, você vai ser fuzileiro naval". [...] E meu coturno sempre brilhando, quase um militar de 15 anos. De fato era. Cabelo sempre curtinho assim, né? [...] O Vicente de 2000 e alguma coisa, 2009, digamos, no auge da carreira militar, pré-militar, o Vicente era o que falava no púlpito, de frente pro prefeito, Câmara de Vereadores, essas coisas todas. [...] Eu era o porta-voz, pegava o microfone. [...] Toda uma formalidade, realmente eu era muito formal. Aprendi muito isso. Falar 
"bom-dia, como vai o senhor?" Era um jovenzinho de 40 anos. Todo mundo fala, até hoje, que eu tenho mais que a minha idade [grifos do pesquisador].

Sentir-se bem por ter sido foco da atenção do padre, "o cara que está com o microfone"; por ser comparado com o padre, "ó o padrinho"; ter um catequista que ele admirava, "um rapaz muito inteligente [... de quem] eu tinha orgulho"; por ser centro das atenções, inclusive usando o microfone, como o padre, "falava no púlpito": esses momentos lhe causaram satisfação no nível fisiológico e o levaram a construir sentimentos e valores capazes de sugerir caminhos específicos, significados como campos de sentidos em diálogo.

No projeto da guarda mirim, o Vicente constrói interpretações também baseadas em experiências vividas no contexto da igreja. Num processo de continuidade de si, utiliza padrões de comportamento e de interpretação em contextos diferenciados. Integrado nas duas esferas de experiência, igreja e guarda mirim, ele se percebe diante da necessidade de fazer uma escolha que julga importante na sua vida. De um lado, está o desejo de ser padre e, do outro, uma promissora carreira militar. Para resolver essa bifurcação na sua trajetória, o Vicente organiza complexos semióticos que, a depender da carga afetiva de cada um deles, tiveram papel importante na orientação e organização do seu sistema de self.

Eu tinha dois grandes futuros a decidir... porque não tinha ninguém graduado na minha família. Ou eu seria um grande militar, pelo que minha personalidade dizia isso [...], sendo guarda mirim, eu seria sub-xerife ou xerife. Não é grande coisa, não, mas pra mim era. A maior hierarquia dentro da guarda mirim seria eu. [...] Tinha deixado a guarda, estava pensando mais em ser padre. Só que o pedido veio pra eu assumir como xerife. [...] O sargento chegou com a carta para eu ser o xerife. Só que automaticamente eu teria que deixar meu projeto de ser padre, para continuar sendo xerife até os 18 anos. [...] Só que isso era setembro pra outubro e eu ia entrar no seminário em janeiro. Novembro faria o encontro e poderia ser chamado para entrar no seminário no próximo ano. [...] Eu na insegurança... eu estava no segundo ano. [...]

"Não, eu não vou assumir. [...] Não quero, porque eu vou deixar a guarda ano que vem, sargento. [...] Eu quero ser padre." [...] Ele [o sargento]: "nossa, eu sabia que você era diferente!" [...] Eu quero ser padre, quero ser missionário. Essa é minha natureza, é isso que eu decido. [...] Por não ficar com remorsos por não ser xerife, que era coisa que eu almejei um certo tempo, eu: "não, realmente eu tenho vocação para ser padre, eu não vou ser militar mais não" [grifos do pesquisador]. (primeira entrevista).

A carga afetiva em relação a ser padre desempenha um importante papel na resolução dessa bifurcação. Se por um lado ser padre era um desejo, carregado de afeto, ser militar era uma possibilidade que correspondia mais às expectativas dos outros do que às do próprio Vicente. Muitos significados valorizados pelo garoto eram comuns às duas possibilidades de trajetória. 
Portanto, ao perceber que abriria mão de ser xerife, passo importante na hierarquia daquele espaço, ele conclui que realmente deveria ter vocação para ser padre. É uma estratégia de escolha onde a carga afetiva tem papel fundamental.

Como resultado da resolução da bifurcação, surge no sistema de self do Vicente a Iposition "eu, vocacionado". Esse posição de eu idealizada pelo Vicente, a partir de suas experiências vividas como importantes, passa a coordenar processos de especificação em direção a contextos como a escola, a família, a guarda mirim, a igreja.

Na adolescência já quase todo mundo está namorando! Tentei namorar, mas já pensando em ser padre, pensando no que as pessoas iam falar de mim, se poderia namorar ou se não poderia! [...] "Ah, então não vou namorar, não”. [...] Eu poderia ter namorado, tive várias oportunidades de namorar com essa idade, com 11, 12 anos, mas tinha essa cobrança de mim mesmo, "o povo está me olhando. Eu já vou ser padre. Eu vou entrar no seminário!"

[...] E eu tomei coragem pra falar. Primeiro com o padre e depois com meu pai. [...] "Padre, eu queria saber como é que eu faço pra ser padre!"

[...] Os meninos queriam assistir vídeos pornô no meu notebook. Eu disse não. "Não vai assistir vídeo pornô no meu notebook." [...] "E por que que não vai? Você é boiola?" "Não, não sou boiola, [...] eu não acho que é cristão. Vai pôr vírus no meu notebook e é contra meus princípios." [...] Alguém perguntou assim: "você vai ser pastor?" Eu disse: "não, não vou ser pastor porque eu sou católico, se eu fosse evangélico eu seria pastor, como eu sou católico eu vou ser padre" [grifos do pesquisador]. (primeira entrevista)

No plano da autorregulação afetiva pessoal, os níveis de generalização podem operar ora possibilitando que signos emocionalmente fortes controlem níveis menos generalizados, ora sugerindo e controlando comportamentos em contextos específicos. Nos trechos de entrevista citados acima, valores generalizados, emocionalmente internalizados, canalizam e orientam ações e atitudes do Vicente.

Ser vocacionado torna-se um valor para Vicente, um fenômeno afetivo de ordem superior (Valsiner, Branco, \& Melo Dantas, 1997). Como recursos semióticos com forte carga afetiva, os valores são observáveis mediante a conduta da pessoa em diferentes situações. Porém, à medida que alcançam a condição de hipergeneralizados, eles "não são mais facilmente acessíveis por meio de processos verbalmente mediados" (Valsiner, 2012, p. 262). Nesse sentido, como campos nebulosos, os valores são complexos, semióticos, dinamicamente coordenados: "é contra meus princípios".

Vicente passa a agir no presente e interpretar o passado orientado fortemente por expectativas de futuro. Presente, passado e futuro são dinamicamente relacionados num tempo irreversível e pessoal. O garoto, dialogicamente, cria signos à luz de um futuro imaginado já 
atuante no presente. Com isso, novas tensões dialógicas são vividas nos planos intra e interpsicológico: "tive várias oportunidades de namorar com essa idade, com 11, 12 anos, mas tinha essa cobrança de mim mesmo, "o povo está me olhando. Eu já vou ser padre. Eu vou entrar no seminário!" Antes mesmo de ingressar na esfera de experiência da guarda mirim, portanto antes de se decidir por ser padre, essa possibilidade de futuro já integrava o sistema de self do garoto, ofertando espaço para algumas ações e inibindo outras.

É nessas relações de tensão e oposição que o desenvolvimento acontece. Ao buscar compreender as trajetórias pessoais, precisamos atentar para as relações e não apenas para as categorias. Vicente vive uma tensão ao resistir a uma orientação sociocultural. Sua ação resiste ao presente em razão de uma reflexão sobre o futuro. O futuro, o vir a ser, o não real, não está no aqui e agora como fato, mas como possibilidade. Ao agir no presente em função de um depois, o sujeito resiste ao que é para criar sentido de um não ser, de um vir a ser. A mudança resulta da resistência ao presente, apoiada numa experiência vivida e numa expectativa imaginada. Assim, o futuro imaginado existe numa relação de tensão e resistência ao presente real (Valsiner, Marsico, Chaudhary, Sato, \& Dazzani, 2016).

Nesse processo de construção de signos em busca de um futuro imaginado, o sujeito resiste a um tempo institucional construindo um tempo pessoal-cultural. Em entrevista, Vicente diz que, no colégio onde estudava, os alunos do segundo ano do ensino médio deviam escolher se iriam focar os estudos em exatas ou em humanas. Segundo relatou, os melhores alunos ficavam nas turmas de exatas, e aqueles com notas medianas ou baixas iam para as turmas de humanas. Ele sempre esteve entre os melhores alunos da turma, e suas expectativas foram consideradas naquela escolha exigida institucionalmente no presente:

no meu segundo ano, ou eu fazia humanas, ou eu fazia exatas. [...] E olhava para aquela lista e pensava: "se eu for fazer marinha ou aeronáutica, está tudo certo, mas se eu for ser padre?” Falei assim: “não!” Eu tinha ótimas notas. Estava sempre no primeiro, segundo ou terceiro lugar ali da sala. "Ah, mas se eu for ser padre eu não vou usar química! Não vou pregar pro povo matemática." E fiquei, minha crise foi aí. E aí eu tinha que decidir rapidamente: marinha ou seminário. E fui conversar com a diretora. [...] "Eu quero mudar de turma, $[. .$.$] porque eu quero ser padre" [grifos do pesquisador].$

O Vicente, mais uma vez, age no presente em função de um futuro probabilístico. Resiste à canalização institucional: "se eu for padre eu não vou usar química!", "tinha que decidir rapidamente". O jovem Vicente vivencia, nesse momento, tensão tanto no interior das esferas de experiência como entre elas, inclusive entre uma esfera de experiência real e uma imaginada.

6.4.3.2 Ajustamentos entre tempo institucional e tempo cultural-pessoal 
Ao ingressar na instituição religiosa, em 2010, Vicente passa a vivenciar a pedagogia de formação do seminário. Até então, tudo que o jovem sabia sobre a realidade do seminário tinha sido pela experiência de terceiros. A sua entrada em um novo microssistema, ampliando seu mesossistema, caracteriza uma transição ecológica, uma mudança espacial importante: sai da casa dos pais e vai morar com um grupo de jovens com um objetivo em comum: ser padre. Toda transição ecológica (Bronfenbrenner, 1996) proporciona alterações da posição da pessoa em diferentes esferas de experiência. Novos processos de desenvolvimento são desencadeados numa relação dialógica com os contextos inéditos. Antes, o Vicente se via e era visto como um vocacionado, um garoto desejoso de ingressar na vida religiosa. Agora, é um seminarista, um vocacionado em formação para o sacerdócio.

A experimentação do contexto da instituição religiosa propicia novos desafios e tensões. Vicente narra que no primeiro ano, 2010, precisou se adaptar à rotina de estudos: fora de casa, o terceiro ano do ensino médio; dentro de casa, leituras relacionadas à formação religiosa. O jovem começa um processo de ajustamento entre significados pessoais e significados institucionais, tempo pessoal-cultural e tempo institucional-cultural. Novos elementos socioinstitucionais passam a estar disponíveis para ser reconhecidos como recursos simbólicos, como discutido no caso Fátima.

O Vicente afirma que os desafios se tornaram mais complexos em 2011, quando, mais uma vez, ampliou seu mesossistema, realizando novas transições ecológicas e desenvolvimentais: com alguns colegas, mudou-se para outra casa de formação, situada em outra cidade, para ingressarem no curso de filosofia. Em geral, os jovens do sexo masculino em formação para a vida religiosa e sacerdotal cursam filosofia e teologia. Em algumas instituições, o candidato ao sacerdócio, na vida religiosa consagrada, cursa filosofia antes da vivência do noviciado, como é o caso do Vicente. Porém, em grande parte das instituições religiosas o candidato cursa filosofia após o ano de noviciado, ou seja, quando já é um religioso com votos simples, como é o caso do Francisco.

Na nova casa de formação, Vicente e outros colegas passam a conviver com jovens mais adiantados na formação para a vida religiosa e cursando o segundo ou último ano de filosofia. A vivência das novas esferas de experiência proporciona novas reflexões, novos desafios e novas tensões dialógicas. Assim, significados são criados e ressignificados pelo jovem, no intuito de lidar com o ineditismo daquela realidade.

Caí na filosofia... A cidade [Tal]... eu morava lá... eu já tinha uma fama de socialista, né? Caí lá, um capitalismo bravo, pelo menos onde nós morávamos. Me deu um choque... no dia que nós chegamos lá eu pensei em sair. Ver os meus companheiros, filósofos, que já estavam há mais tempo, o discurso deles, a forma de eles se vestirem. [...] Então já me deu um choque. E também as inquietações: "será que eu vou ser padre mesmo? Será que eu 
não vou casar?" [...] Fui cair na filosofia e pensei: "vou largar, chutar o balde". No primeiro dia que eu cheguei lá eu pensei em fazer isso. Falei: "não. Eu nunca fui covarde. Covardia não está no meu princípio. Eu vou pelo menos seis meses”. E de lá pra cá eu vim com esse propósito: "eu vou ficar seis meses e nas férias eu penso. Seis meses e nas férias eu penso". Eu sempre faço um propósito mais ou menos assim, enfrentar e decidir. Motivos de sair? Brigar com o formador. O formador que tem um pensamento diferente que o meu. Mas depois eu vi e sempre pensei que minha vocação é mais que isso.

Mas a filosofia virava no meio... o que que é vocação? [risos] Primeiro minha vocação era mais que isso. Tão preciosa. Tão guardadinha, precioso, ela tentava assim... “ $O$ que é vocação?", a filosofia questionava, né? A vocação do Vicente, "quem é o Vicente?" Não, foi Deus quem chamou, "quem é Deus?" A filosofia é... cruel nesse ponto. Mas eu agradeço muito a ela. [...] Agradeço a filosofia. Na época que ela me fez sofrer eu não gostava, mas hoje agradeço. O sofrimento que ela me propôs, o sofrimento leva à ressurreição. [...] Caí no mundo acadêmico. Ainda estava mil flores aqui, uma redoma de vidro, muito bonito. Você cai na filosofia, ainda com um discurso "eu sou seminarista", chegar num meio acadêmico, com todas as religiões, pessoas com mentes muito abertas, que liam muito mais do que eu. [...]

Enfim, minha cabeça ficou... 1001 perguntas. [...] A filosofia é terrível. Mas o Vicente estava se descobrindo enquanto pessoa e se dava essa abertura: "você pode ter sentimentos. Você não tem essa culpabilidade”, porque até então, em 2009, 2011, minha mente era fechada inclusive pra masturbação. Só de pensar, era fechado, era pecado, tudo era pecado, né? Uma coisa que na filosofia a mente abre um pouco mais. Não sei se depois vai fechar, espero que não. Não posso falar do futuro, mas espero que não [...], minha relação com o sagrado é outra [grifos do pesquisador]. (primeira entrevista)

Vicente destaca a pluralidade encontrada na nova casa de formação e no ambiente acadêmico. Essa pluralidade se traduz no seu encontro com novos outros, com outras formas de ser seminarista, de ser jovem, de conceituar pecado, de se relacionar com o sagrado. À medida que o mesossistema do sujeito é ampliado, novas necessidades de ajustes são criadas, novos modos de ler a realidade são sugeridos e, com isso, novos questionamentos sobre si e sobre as próprias escolhas emergem.

Nesse lidar com o inédito, Vicente chega a considerar a possibilidade de abandonar a formação, um conflito que é potencializado pelas reflexões no curso de filosofia. São sugeridos novos modos de pensar sobre vocação, sobre Deus, sobre matrimônio, sobre si mesmo. E essa tensão abre a possibilidade de uma nova trajetória: abandonar o seminário e retornar para a casa dos pais. Na busca de resolver essa tensão, o jovem recorre ao signo covardia, ao qual ele já havia recorrido em uma discussão com o pai, quando lhe informou que recusara ser xerife porque estava 
decidido a entrar no seminário. Na ocasião, o pai criticou a atitude do filho e disse que não permitiria que ele ingressasse no seminário aos 16 anos e antes de terminar o ensino médio. O pai reafirmou o desejo de que o filho, ao fim do ensino médio, ingresse na marinha ou na aeronáutica. $\mathrm{O}$ garoto argumentou, selecionando experiências e significados colocados em diálogo com um futuro em aberto. Assim, buscou uma negociação de sentidos com o pai:

eu faço experiência de um ano. Se não der certo, foi o que o padre falou comigo, se não der certo eu faço o ENEM lá mesmo e já volto pra entrar para a marinha ou pra aeronáutica, seja onde for, mas eu quero tentar. Eu não quero morrer, sendo covarde e falar que eu não tentei. Quando eu falei "covarde", covarde é uma palavra que meu pai não admite. [...] Quando eu falei pro meu pai "covarde", tocou muito meu pai. Eu imagino que sim, pela reação e expressão dele [grifos do pesquisador]. (primeira entrevista)

O sentido de covardia está ancorado em sugestões sociais significativas da esfera de experiência familiar. Na discussão, ao compartilharem o sentido da palavra "covardia", pai e filho negociam sua relação com o significado de ingressar no seminário, "eu quero tentar". $\mathrm{O}$ posicionamento remete ao signo "arriscar", indicado pelo próprio Vicente como signo que lhe garante um sentido de continuidade de si: "desde pequeno. [...] Isso não muda em mim. [...] Questão de arriscar. Acho que isso ninguém tira de mim", nem o próprio pai. Assim, o não arriscar é ficar parado, é crise, "se você age na crise... o melhor caminho é o caminho que você escolhe". Não arriscar caracteriza covardia, uma atitude que contraria os princípios dele e de seu pai. Portanto, ao recorrer ao signo covardia para justificar por que não poderia desistir sem tentar, Vicente busca um sentido de integração do self. Ele se convence da necessidade de tentar, de arriscar, como condição de dizer para si mesmo se queria continuar em formação no seminário.

Outro ponto importante no trecho de entrevista que aponta tensões vividas nesse encontro com novas esferas de experiência, em 2011, é a metodologia que ele afirma ter adotado desde então para a resolução de dúvidas, de momentos de bifurcação: “'eu vou pelo menos seis meses'. E de lá pra cá eu vim com esse propósito: 'eu vou ficar seis meses e nas férias eu penso. Seis meses e nas férias eu penso'. Eu sempre faço um propósito mais ou menos assim, enfrentar e decidir".

O sujeito cria significados para lidar com tensões, dúvidas, em busca de realizar um futuro imaginado. Para lidar com a incerteza se queria mesmo chegar a ser padre, Vicente executa decisões a curto prazo. É como se buscasse estreitar seu horizonte de projeção no futuro, delimitando-o a partir de um tempo cronológico. Trata-se de uma tentativa de controle e diminuição da tensão causada pelo desconhecido. Dessa forma, o jovem utiliza o signo "propósito" para traduzir um campo de significados complexo e dialógico.

$\mathrm{Na}$ discussão com o pai, em 2009, quando este quer proibi-lo de ingressar no seminário, Vicente também faz referências a essa metodologia, como uma sugestão vinda de um padre em um dos encontros vocacionais de que participou: "eu faço experiência de um ano. Se não der certo, foi 
o que o padre falou comigo, se não der certo eu faço o ENEM lá mesmo e já volto pra entrar para a marinha ou pra aeronáutica". Essa maneira de lidar com as tensões é utilizada em outros momentos da entrevista. Refletindo sobre seu ingresso no noviciado, Vicente diz: "eu sinto que eu vou seguir a caminhada. Vou pro noviciado, um passo de cada vez, né?" Em outra situação, uma conversa com um dos formadores que questionava a possibilidade de ele concluir o curso de filosofia em 2014 para então ingressar no noviciado, em 2015, diz: "ele queria que eu desse uma resposta pra meu futuro todo. Eu parei, não respondi, pensei comigo: 'um passo de cada vez, um passo de cada vez. Primeiro eu falo de filosofia, depois eu penso no noviciado"”.

Essa mesma "recusa" em tomar uma decisão com caráter definitivo vai aparecer em outra importante bifurcação da trajetória do Vicente, quando precisa decidir entre ordenar-se sacerdote, assumindo os compromissos que tal título impõe, e ser irmão consagrado ${ }^{13}$ (discussão a ser retomada posteriormente). Entretanto, essa postura perante as tensões dialógicas, de tomar uma decisão que deixa brechas para diversas possibilidades no futuro, se mostra como uma maneira assumida pelo Vicente para lidar com as tensões causadas pela incerteza da concretização de seus futuros imaginados.

O ingresso no contexto universitário é um cruzamento de fronteira espacial, assim como o encontro com a filosofia sugere um cruzamento de fronteiras semióticas. Os sujeitos "cruzam fronteiras postas por eles mesmos ou postas para eles mesmos por outros" (Valsiner, 2012, p. 206). Frequentar o ambiente universitário como aluno de um curso superior tem exigências sociais, institucionais e pessoais. Como um ambiente físico e sociocultural, a universidade proporciona, e exige, reposicionamentos do sujeito, com novos limites e possibilidades de ação.

Os novos modos de ser e de sentir do sujeito, canalizados por uma nova esfera de experiência, não são determinados de modo exclusivo pelo sujeito nem pelas instituições ou contextos. Antes, são resultados da qualidade da relação do sujeito com os limites e as possibilidades do ambiente, bem como das maneiras singulares adotadas na resolução de tensões ali constituídas: "a filosofia é terrível. Mas o Vicente estava se descobrindo enquanto pessoa e se dava essa abertura".

Vivenciar um curso superior, por si só, não é um fator determinante de certos tipos de questionamento em relação a si e ao mundo. O modo como a pessoa encara e atribui significado a essa experiência deve ser analisado considerando não só sua história pregressa, mas também seus horizontes de projeção em diálogo com sua realidade no aqui e agora. Nesse sentido, mais

13 Tanto na instituição religiosa da qual Vicente faz parte como na do Francisco, o candidato à vida religiosa consagrada pode escolher se ordenar sacerdote ou não. Ao professarem publicamente os votos de pobreza, castidade e obediência, os jovens se tornam religiosos reconhecidos pela igreja. Portanto, todos são irmãos consagrados. Depois, caso queiram ser ordenados sacerdotes, precisam cursar teologia, mas ser padre não é uma imposição da instituição religiosa. É uma escolha do candidato. 
importante que compreender por que o Vicente orienta a significação do seu encontro com a filosofia em uma determinada direção é compreender como esse modo de dar sentido para tal experiência, em diálogo com outros complexos semióticos, integra seu sistema de self e passa a orientar atitudes, interpretações e sentimentos em relação ao passado e ao futuro.

\subsubsection{Ser leigo consagrado ou ser clérigo}

Antes de ingressar no seminário e iniciar sua formação, Vicente tinha a intenção exclusiva de ser padre, ou seja, clérigo: "quando eu cheguei na congregação, não tinha muita distinção do que é padre, do que é irmão. Entrei para ser padre". Desde criança, aprendeu a admirar a pessoa do padre e, por motivos variados, gostava de observá-lo: o padre usava o microfone, falava bem, era respeitado e admirado pelo povo. Ao ingressar na congregação como candidato ao sacerdócio, mediante a pedagogia formativa daquele contexto, Vicente descobriu que, antes de ser padre, seria um leigo consagrado, ou seja, um irmão, um religioso com votos de pobreza, castidade e obediência; e depois poderia optar por continuar como leigo consagrado ou se tornar um clérigo consagrado, ordenando-se sacerdote.

Ao compreender melhor essas possibilidades de vivenciar sua vocação, Vicente hipotetiza a ideia de continuar como leigo consagrado e não se ordenar padre. Acrescenta uma nova possibilidade de trajetória, experimentando mais uma tensão dialógica, cuja resolução exigiria dele a criação de outros significados. Nesse processo decisório, Vicente começa a avaliar o próprio comportamento, as experiências dentro e fora do contexto institucional, os colegas, padres e não padres, outros religiosos de diferentes instituições, e especialmente limites e possibilidades que cada modo de vida oferecia.

Eu queria ser missionário, ir para a Amazônia, talvez. Fui para uma paróquia bem missionária, em 2011, fui pro Mato Grosso, na romaria dos mártires. Só que parava pra pensar, aquilo tudo era missão. Missão motivava tudo. E se tudo era missão... eu já não estava mais querendo ser padre porque tinha uma visão nega... estava começando a negativar os padres, alguns padres... eu quero ser só irmão, só frei, só religioso, né? Mas se eu vou ser religioso... eu com 17, não tinha 18 anos na universidade ainda, com 17 anos, ia fazer 18, e não vou casar, e não vou ser padre, não vou rezar missa, não vou atender confissão e não vou ser um leigo, porque eu não vou ser um leigo, assim pelo menos ia casar.

[...] Eu quero ser irmão. Eu penso em ser religioso. Se vai ser padre, é consequência. Penso muito em ser religioso, não ser padre. Religioso, não padre. E eu 
acho que vai... pelo menos eu me formo pra isso. Minha formação, minhas leituras, meus encontros, minha pastoral, é voltado pra ser um religioso que não usa túnica, porque quem usa túnica é padre, irmão não usa. Então eu penso, me formo... você não pode ter um pensamento indeciso, tem que decidir logo, o tempo vai passando e você tem que decidir algumas coisas. Eu penso em ser religioso. Em ser Vicente, em ser irmão Vicente. E esse ser do Vicente se forma agora como religioso. [...] Desde 2012 pra cá, eu já falava isso, "vou ser irmão", numa conversa aqui com os meninos eu falei "vou ser irmão". [...] Noviciado pra mim é uma etapa especial. Eu vou sair de lá como irmão? Não sei! Eu quero me entregar ao meu noviciado. Ver o que o noviciado vai me dizer. [...] Em total liberdade... me vejo livre, pra quaisquer fins, matrimônio ou não. Matrimônio não é o meu pensamento hoje. Mas eu não hesitaria. De certa forma já é uma segurança, né? Pensar que eu sou livre, mas também... não sei! [...] Por isso eu penso em estar livre.

A minha ideia em ser irmão é ser mais livre. Eu não quero ser padre pra me prender em uma paróquia. Em certo... tudo é prisão na vida, né? Hoje eu vejo isso. Mas pra mim, entre padre e irmão, o irmão é mais livre. A questão de estar na paróquia hoje, como padre, eu tenho que pensar nas confissões dos fieis, pensar em tudo... são compromissos que devem ser assumidos por alguém. Mas meus compromissos, e todos os compromissos que eu venha a assumir, que aí me vejo, é dando assessoria para as pessoas que eu vejo como mais excluídas, né, libertação mesmo. [...] A imagem que eu vejo do Vicente: barbudo, não precisa ser barba grande, numa moto, [...] meio roqueiro mesmo, viajando no Tocantins, dando assessoria pra pastoral de surdos, pra liturgia, [...] indo pra dar formação em Brasília, por exemplo, pra pastoral da juventude, depois volta pra Tocantins, pra sua paróquia ou pra sua obra social, porque, se não é padre, não necessariamente precisa ser uma paróquia [grifos do pesquisador]. (primeira entrevista)

Os signos "missão" e "liberdade" são importantes na organização hierárquica dos valores do Vicente em relação a ser leigo consagrado. Ele deseja não estar preso aos compromissos paroquiais para ser missionário, em diferentes locais, "aí me vejo, é dando assessoria para as pessoas que eu vejo como mais excluídas". Isso pode estar ligado aos primeiros sentimentos positivos que ele teve em relação à pessoa do padre: um padre que está no meio do povo, com as pessoas, e não só dentro da igreja, envolvido com atividades que se limitam às paredes da igreja. Tanto que, a primeira vez que partilhou com a mãe o desejo de ser padre, ela disse "“você quer ser padre?' [...] Falei assim: 'quero, quero ser padre, como o padre [Fulano...]. O povo gosta dele. Padre povão, o povo gosta dele" (primeira entrevista).

Já em experiência formativa no seminário, o Vicente começa a comparar atitudes e comportamentos de padres e religiosos, aprovando algumas e desaprovando outras. Assim, em 
diálogo com um futuro imaginado, coloca em questão o tipo de padre que gostaria de ser. Nesse processo começa a questionar a formalidade que inicialmente lhe chamara a atenção.

Eu chamei um amigo: "você quer fazer o salmo?" Ele foi, levou o violão, o rapaz canta muito bem. O padre veio me chamar a atenção porque ele não estava a caráter pra estar naquela igreja [o fato ocorreu quando Vicente cursava o primeiro ano de filosofia e morava em uma paróquia frequentada por pessoas de classe média e alta]. [...] Eu falei "padre..." Esse dia eu ia embora, eu deixei o prato de comida e subi pra arrumar minha mala. "Vocês podem tirar a missão da igreja de mim, mas não vão me tirar da missão da igreja". Uma frase que eu falei no impulso, depois que eu fui refletir, eu vi que de fato a missão abrange a igreja, mas é maior que a igreja, né? A missão está em tudo. Ela não se fecha na igreja" [grifos do pesquisador]. (primeira entrevista)

O signo missão toma um lugar de destaque na hierarquia de valores do jovem, fazendo emergir novos modos de ser e de sentir em relação à sua vocação para a vida religiosa. Em 2011, o Vicente teve a oportunidade de participar de uma missão da igreja, no interior de Minas Gerais. As missões são eventos onde padres, religiosos e religiosas se deslocam para comunidades no intuito de desenvolver atividades pastorais, destacando a evangelização como essência missionária da Igreja Católica. Em geral, as missões são realizadas onde a assistência de padres e freiras é mais escassa. Tal experiência possibilita uma maior identificação do Vicente com esse trabalho, levando-o a repensar seu desejo de ser sacerdote e concentrar seu trabalho no interior de uma paróquia.

O desejo de ser padre, a vocação para a vida religiosa consagrada, emerge na trajetória de vida do Vicente em um contexto muito próximo das experiências proporcionadas pela missão. E as atividades destinadas a um padre, no interior da igreja, começam a soar para o jovem como um empecilho para a liberdade, visto que são compromissos repetitivos e monótonos: "eu vi caminhada de irmãs e de irmãos maristas, lazaristas, muito inseridos na sociedade. Eu gostei disso! [...] Não é no sentido de preguiçoso. Eu não sei... é por questão de caminhada, mesmo!"

Outro fato importante na vivência dessa indecisão entre ser clérigo ou leigo consagrado foi o encontro do Vicente com a Pastoral de Surdos. Também em 2011, ele cursou na faculdade um semestre de Língua Brasileira de Sinais (Libras). Desde então, interessou-se pela língua de sinais e resolveu, em 2013, fazer um curso completo de Libras para se especializar. Assim, transformou o elemento cultural Pastoral de Surdos em uma perspectiva de futuro, como recurso simbólico.

Considerando as possíveis trajetórias futuras, o Vicente vivencia um ajustamento entre tempo pessoal-cultural e tempo institucional. Antes e durante o noviciado, ele poderia viver o ser irmão leigo consagrado como uma possibilidade, pois somente ao final do noviciado a instituição exigia dele uma escolha. Dessa forma, em um tempo pessoal, Vicente já vivia, desde 2012, essa possibilidade de ser irmão, mas a concretização e o reconhecimento de tal título só eram possíveis 
num tempo institucional. Por isso, Vicente interpreta o noviciado como um tempo especial, onde poderá encontrar respostas para tais dúvidas: "noviciado pra mim é uma etapa especial. 'Eu vou sair de lá como, irmão'? Não sei! Eu quero me entregar ao meu noviciado. Ver o que o noviciado vai me dizer".

Por sua vez, a decisão de ser leigo consagrado apresentava outras tensões (Figura 5). Para a Igreja Católica, toda pessoa batizada é um leigo, chamada a viver o Evangelho nas diferentes atividades do cotidiano e nos diversos espaços sociais. Aqueles que ingressam em uma ordem ou congregação religiosa professam os votos religiosos e passam de leigos a leigos consagrados. Por isso Vicente começa a se questionar se não seria melhor continuar sendo leigo não consagrado e abandonar a vida religiosa, pois isso lhe possibilitaria casar-se: "porque eu não vou ser um leigo, assim pelo menos ia casar. [...] Não sei... mas minhas escolhas, ah, a melhor escolha é aquela que você faz. Não sei, minha escolha na verdade apaga muitas outras, né?"

Figura 5. Possibilidades de trajetórias antes de ingressar no noviciado

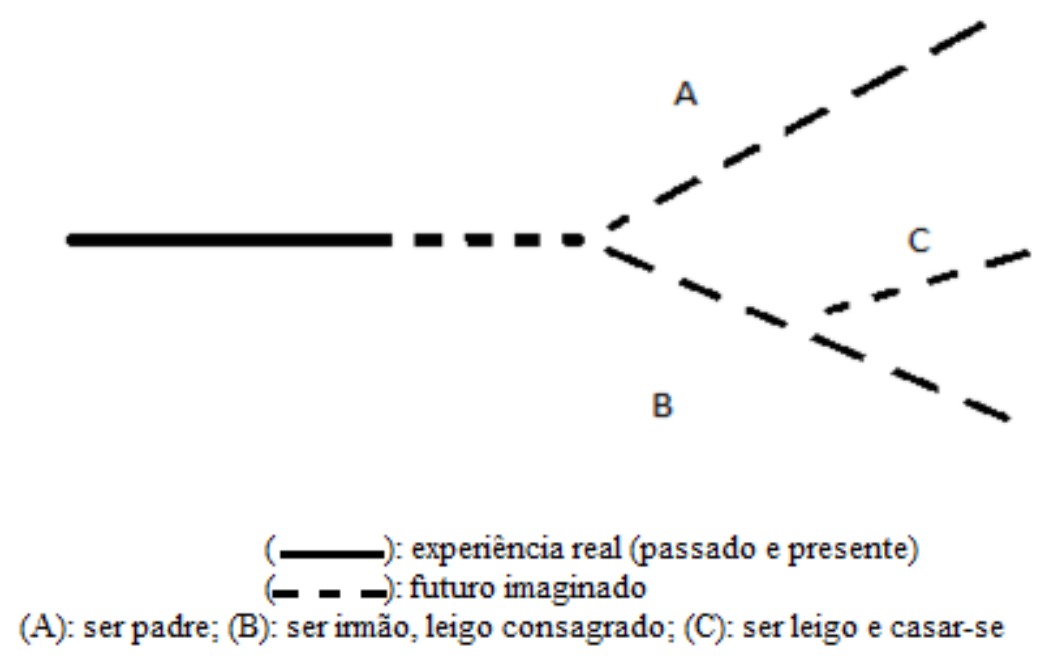

Fonte: Adaptada a partir de Sato, Hidaka \& Fukuda, 2009, p. 227.

Um complexo semiótico referente ao desejo de ser leigo consagrado envolve diferentes significados, muitas vezes contraditórios, em constante diálogo. Nesse complexo, os significados de "missão" e "liberdade" na trajetória de vida do Vicente passam a orientar e organizar outros elementos do complexo, sugerindo modos de ser e de sentir do jovem em diferentes esferas de experiência: instituição religiosa, espaço universitário, Pastoral dos Surdos, noviciado, encontro com outros religiosos. 
Figura 6. Complexo semiótico: "ser leigo consagrado X ser clérigo"

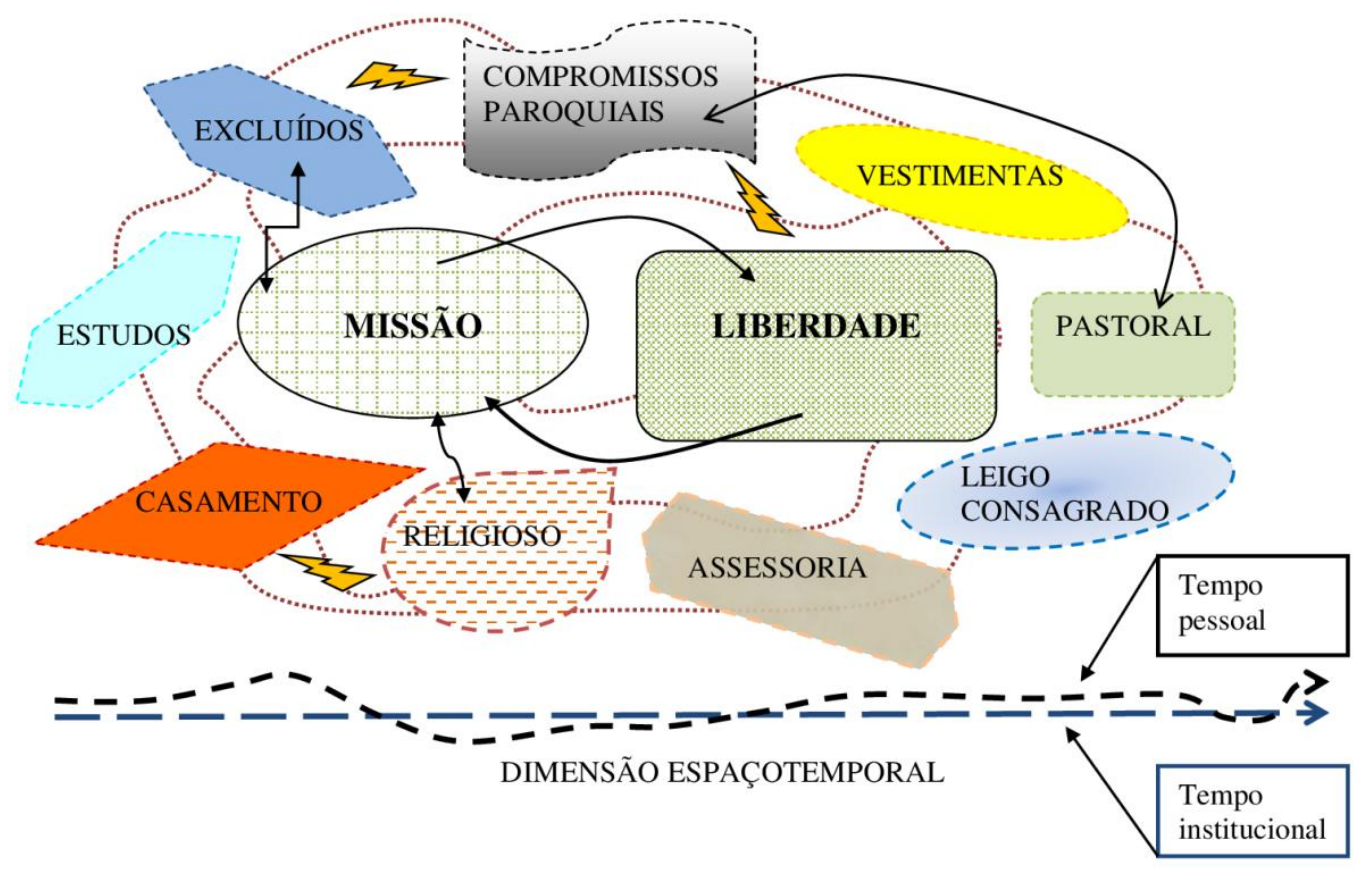

Fonte: Elaboração do pesquisador

Ao final do noviciado, Vicente ainda não tem certeza sobre seu estado religioso na igreja (ou prefere deixar os planos em aberto). E tal incerteza é fruto de relações de tensão entre as esferas de experiência que vivencia. As tensões dialógicas acontecem pela necessidade que o sujeito sofre, e sente, de se ajustar às instituições, às crenças e aos valores socioculturais. Desde o seu ingresso na formação para a vida religiosa consagrada, considerando suas experiências dentro e fora do seminário, suas decepções e suas perspectivas futuras, seu encontro com a filosofia, suas reflexões pessoais e coletivas, Vicente busca criar significados que justifiquem a concretização de um futuro como leigo consagrado e não como clérigo. Chega a apostar nas experiências que viveria no ano de noviciado como capazes de lhe indicar um caminho a seguir. Mas, ao final do noviciado, ainda se sente em dúvida e recorre, novamente, à metodologia de escolher, de modo a abrir possibilidades para o futuro e não fechar em uma única alternativa: "projetos em aberto".

Olha, teve um dia que foi angustiante, viu? Pra você passar pro pessoal que você quer ser irmão, no meu caso, na minha província só tem um irmão, a maior parte é clérigo, é complicado! Eu saí da minha paróquia em 30 de janeiro de 2010. Eu e um amigo fizemos missa de envio. Esse meu amigo é de outra congregação, professou agora, 15 de janeiro, e quer ser padre. Então, nós saímos de túnica, de cinto, tudo bonitinho. Então, [...] o povo fica naquela cobrança, [...] "Vicente, futuro sacerdote da Santa Igreja", [...] "vamos rezar por ele”. [...] Expliquei certinho. Então o padre reza missa, confissões, casamentos, batizados, sacramentos. O religioso, ele está na comunidade e também na pastoral, 
catequese, trabalho com surdos. Expliquei. Entendido? "Entendido." Mas na hora que termina... [...] agora eu vou para uma comunidade, como irmão, vou trabalhar em obras sociais. Também da igreja, nas coisas sagradas da igreja, mas coisas sagradas que não são da igreja. Tentei explicar isso.

Pois na congregação quando você fala que vai ser irmão o pessoal olha assim: "o preguiçoso, não quer rezar missa, não quer celebrar os sacramentos". Eu já olho pelo contrário. Eu quero estudar, enfim, eu quero por outros meios... [...] Quando eu falo isso ainda é uma luta, porque tem muitos padres que falam assim: "ah, isso é conversa fiada. Fulano falou que ia ser e depois, três anos, quatro anos de teologia decidiu ser padre" [grifos do pesquisador]. (segunda entrevista)

O episódio acima ocorreu no final do noviciado de Vicente, quando ele tentava explicar para as pessoas da comunidade onde cresceu que não iria ser padre, e sim leigo consagrado. No momento da segunda entrevista, o Vicente havia professado os votos religiosos e anunciado que seria irmão. Porém, ainda sentia a pressão daqueles que criticavam e não apoiavam a sua decisão. Por um lado, há muita cobrança das pessoas que o viram crescer dizendo que seria padre, as quais, como ele mesmo ao ingressar no seminário, não compreendiam com clareza a diferença entre padre e irmão. Por outro lado, os padres e formadores da instituição religiosa não apoiavam nem davam credibilidade aos jovens que diziam querer ser leigos consagrados. Muitos acreditavam tratar-se de preguiça de assumir os ministérios da igreja, as atividades pastorais que são de obrigação do sacerdote. Outros sugeriam que seria "conversa fiada" de jovens indecisos, considerando que os poucos que optaram por ser irmãos, em geral, voltavam atrás e resolviam se ordenar padres.

$\mathrm{Na}$ Igreja Católica, apenas homens se ordenam sacerdotes. Optar por ser leigo consagrado, de certo modo, é desenvolver um trabalho na igreja que pode ser desempenhado pelas freiras. Inclusive, ao tentar explicar a diferença entre ser leigo consagrado e ser clérigo, Vicente recorre ao exemplo das freiras: “eu, como irmão... conhecem irmã, conhecem freira? Mais ou menos a mesma coisa, só que é homem. Mais fácil explicar. Cuidar de hospital, obras de caridade, assim, assim, assado". Portanto, essa resistência à expectativa social de que o homem que ingressa no seminário virá a ser um clérigo entra em diálogo com o ideal de liberdade do Vicente: "pra mim, entre padre e irmão, o irmão é mais livre".

Por outro lado, a decisão de cursar teologia parece mais uma maneira que o jovem encontra para lidar com a resistência a projetos fechados. O curso de teologia não é obrigatório aos jovens que optam pelo estado de leigo consagrado na igreja, mas o irmão leigo consagrado pode, a qualquer momento, decidir ser clérigo e solicitar à instituição autorização para ser ordenado padre.

Quero fazer teologia, opção minha fazer teologia, quero fazer teologia, mesmo sendo irmão. Não quero ninguém depois me pondo lá em baixo. [...] Eu vou fazer teologia. “Ok. E depois?” Depois eu vou fazer uma especialização com surdos. Eu vou trabalhar com 
surdos. Uma pós, alguma coisa. Um curso pra trabalhar com catequese pra surdo [grifos do pesquisador]. (segunda entrevista)

Porém, ao justificar a escolha por cursar teologia, o jovem ressalta a possibilidade de estabelecer uma discussão de igual para igual com os sacerdotes teólogos. Quer primeiro cursar teologia e só depois aprofundar seus conhecimentos para trabalhar com Libras. De qualquer forma, ao ser entrevistado pela segunda vez, o Vicente reafirma que a decisão de ser leigo consagrado levou em consideração experiências ao longo da sua formação até aquele momento, bem como, e especialmente, suas perspectivas de trabalhar com missão, com Pastoral de Surdos, e não se prender às atividades pastorais no interior de uma paróquia.

\subsection{Desenvolvimento de sistemas de self em diálogo com futuros imaginados: o conceito teórico-analítico de Horizontes de Projeção de Self}

O conceito de Horizonte de Projeção do Self (HPS) é fruto de nossos esforços no desenvolvimento de um modelo abstrato que contribua na compreensão do modo como a orientação para o futuro passa a integrar o sistema de self — ou deixa de fazê-lo. A construção do senso de si mesmo, à medida que os sujeitos colocam o futuro imaginado em diálogo com os signos do passado à luz do sistema de circunscritores socioculturais e vivenciais, enseja a emergência de um leque de futuros possíveis. E, assim, ao povoarem o sistema de self, os horizontes de futuro desempenham também um efeito canalizador de trajetórias, num tempo irreversível e pessoal. Nossa ênfase está na modelização sobre o desenvolvimento do self, com base em um frame que integra a ideia de self como unidade dinâmica, entendida na interação com o tempo, a experiência e a imaginação.

A metáfora de "horizonte" aqui utilizada remete à capacidade humana de construir significados projetados em imagens internas de realidades futuras. São cenários criados de modo ativo pelo sujeito, por meio de interações intra e interpessoais. Assim, os horizontes futuros ganham significado numa temporalidade cultural-pessoal (Simão, 2016), onde o espaço-tempo pessoal dialoga com o espaço-tempo social. Portanto, os horizontes futuros devem ser entendidos na interdependência da localização das imagens projetadas.

Não estamos falando de um espaço físico e limitado, mas de uma espacialidade temporal de significados construída pelo sujeito mediante recursos simbólicos e contextos socioculturais. Nesse horizonte de possibilidades, o sujeito projeta modos de ser e de sentir, suprindo sua necessidade de fazer sentido do mundo e nutrir sua dimensão afetiva, em direção ao futuro desconhecido. 
Os HPS são espaços semióticos fantasiados a partir de experiências vividas e imaginadas. Suas fronteiras simbólicas estão sempre em movimento, devido às constantes negociações de significado entre o sujeito e a cultura. Os horizontes de futuro são coordenados por limites e possibilidades do aqui e agora, ao mesmo tempo que canalizam modos de significação do real. Nesse sentido, a noção de imaginação se torna central na discussão do HPS como parte do sistema de self.

Segundo Tateo, em trabalho recente sobre o pensamento do filósofo Giambattista Vico (1669-1744), a habilidade de imaginação da pessoa se fundamenta em três funções da mente: "fantasia, a capacidade de imitar e mudar; inteligência, a capacidade de criar correspondência entre coisas e a memória, ou seja, a capacidade de lembrar" (2015a, p. 49, tradução nossa). Nesse sentido, a imaginação e o pensamento metafórico são constituintes na construção de sentidos de si e do mundo, na (re)significação do "como é" (passado e presente) e do "como pode vir a ser" (futuro).

Mediante sua capacidade imaginativa, o ser humano antecipa realidades e inova modos de sentir e de estar no mundo. A imaginação é a base de toda atividade criativa (Vygotsky, 2004), um processo simbólico fundamental na criação e transformação dos signos (Tateo, 2015b, 2016), fortemente movido pela dimensão afetiva. É um processo desenvolvido na história do sujeito, que participa na produção de sentidos canalizados por contextos socioculturais (Pern, 2015; Zittoun, 2015).

O processo imaginativo é parte da construção de realidades pessoais e culturais. Na sua dimensão histórica, a imaginação participa do desenvolvimento nos níveis ontogenético (Vico, 2004, citado por Zittoun, 2015), microgenético (Pern, 2015) e sociogenético (Granatella, 2015). Assim, "imaginação — como o processo de imaginar — aparece como uma das possibilidades de articulação entre a pessoa e a sociedade" (Zittoun, 2015, p. 254). E essas articulações, ao longo da trajetória de vida do sujeito, inovam os HPS, que por sua vez integram essas mesmas trajetórias.

Assim, o sujeito constrói HPS mediante relações dialógicas com recursos simbólicos, objetos culturais e sistemas semióticos produzidos culturalmente. Essas relações são estabelecidas a partir de limites e possibilidades relacionados aos circunscritores pessoais, considerando a trajetória do sujeito. Logo, os HPS resultam da capacidade humana de imaginar-se numa realidade futura, orientado por uma temporalidade cultural-pessoal (Simão, 2016).

É premissa central na psicologia cultural que os seres humanos constroem significado de maneira constante e dinâmica, na relação com sistemas simbólicos ofertados pela cultura (Bruner, 1997). Esses sistemas funcionam como circunscritores sociais na canalização de processos de socialização da pessoa, e ao mesmo tempo como ferramentas utilizadas pelo sujeito na construção de sentidos de si e do mundo. Assim, nas mudanças do sistema de self, bem como na vivência e significação das transições de desenvolvimento, a pessoa utiliza ferramentas sociais, que orientam 
processos singulares de internalização de sentidos, que por sua vez passam a atuar como circunscritores pessoais.

Nesse constante movimento semiótico, a linguagem comparece como ferramenta por excelência na construção narrativa do self. O sujeito elabora narrativas de si como forma objetiva de se localizar no mundo, num tempo e espaço simbolicamente constituídos. Desse modo,

podemos dizer que as narrativas culturais e os processos de produção de significado que elas ativam, de certa forma orientam outras elaborações semióticas sobre tópicos relevantes para as experiências da vida cotidiana, bem como para as futuras práticas e ações culturais. (Branco, 2015, p. 244, tradução nossa)

Se, por um lado, "nós não temos outra maneira de descrever o tempo vivido a não ser na forma de uma narrativa" (Bruner, 1997, p. 12), por outro, é mediante processos imaginativos e criativos que o ser humano constrói um vir a ser, no qual projeta o próprio self como possibilidade, colocando em diálogo o espaço-tempo pessoal e o espaço-tempo social. E, assim, ocorre uma dupla regulação no sistema de self: limites e possibilidades do aqui e agora em diálogo com HPS (Figura 7).

Figura 7. A regulação semiótica no fluxo de experiência para o futuro

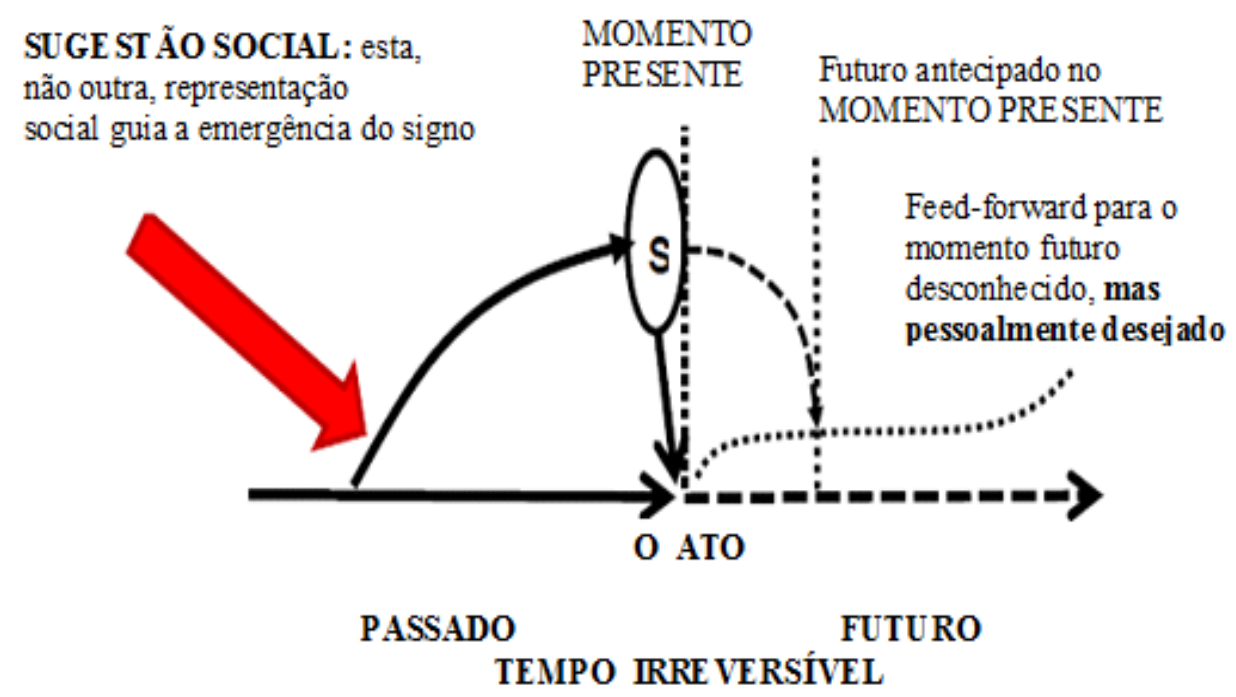

Fonte: Valsiner, Marsico, Chaudhary, Sato, \& Dazzani (2015)

A figura 7 faz uma representação simples de como possíveis selves (Markus \& Nurius, 1986) - posições de eu imaginadas, desejadas ou temidas pelo sujeito — podem funcionar como circunscritores pessoais, canalizando modos de ser e de sentir, bem como comportamentos e escolhas no aqui e agora. 
Na discussão dos estudos de caso, destacamos sugestões sociais — no contexto da família, da igreja e do trabalho, no grupo de amigos, na guarda-mirim, entre outros — que, de certa forma, orientaram a emergência do signo vocação para a vida religiosa. Isso possibilitou a construção de futuros imaginados, projetando ali imagens como "eu, padre", "eu, religiosa", "eu, noviço", "eu, professo temporário", "eu, leigo consagrado". E, assim, ações no presente passaram a ser coordenadas não só pelos limites e pelas possibilidades socioculturais, mas também por imagens de si projetadas num horizonte de possibilidades.

Ao integrarem o sistema de self do sujeito, os HPS passam a atuar, dialogicamente, na (re)construção do sistema no fluxo da experiência, em direção ao futuro, num tempo irreversível. Trata-se de um processo dinâmico pelo qual o sujeito, na consideração de um tempo vivido, de limites e possibilidades socioculturais, constrói sentidos de si, sintetizados em posições de self concretizáveis. E tais posições passam a operar na canalização de escolhas e ações relacionadas ao presente e ao futuro, fazendo com que o desenvolvimento do sistema de self aconteça de modo prospectivo, numa relação dinâmica e dialógica entre futuro, presente e passado.

$\mathrm{Na}$ adolescência já quase todo mundo está namorando! [...] “Ah, então não vou namorar, não.” [...] Eu poderia ter namorado, [...] mas tinha essa cobrança de mim mesmo: "o povo está me olhando. Eu já vou ser padre". (Vicente, primeira entrevista)

Aí eu parei de estudar pra realmente me dedicar a isso. Aí foi um ano pra eu começar a fazer o discernimento vocacional, foi dos 18 aos 19 anos. [...] Com 19 anos eu vim pra conhecer o convento, a vida religiosa. (Cecília, primeira entrevista)

Não será só um simples falar, uma simples forma. Mas aquilo que eu já comecei a viver e agora eu falo assim: "eu quero, eu quis e creio e é isso que eu vou fazer". E é ver que tudo aquilo que eu sonhei, tudo aquilo que eu construí, começa a se realizar nos meus votos. (Francisco, primeira entrevista)

Então eu quero usar. [...] Eu vou cortar meu cabelo bem curtinho pra usar o hábito. E depois que eu começar a usar o hábito mesmo, vai ser quase que outro, né? Porque queira ou não queira, o hábito faz a diferença, assim, num ambiente que a gente está. (Fátima, primeira entrevista)

A experiência antecipada de possíveis modos de ser e de sentir coordenou nos jovens a construção de circunscritores pessoais em diálogo com circunscritores sociais, sendo estes os limites e as possibilidades ofertadas pela cultura e aqueles os significados inéditos construídos pelo sujeito nas esferas de experiência. Na presente pesquisa, crenças e valores, histórias de santos, vestimentas, o ser coroinha, posturas, objetos religiosos e a própria pedagogia de formação para a vida religiosa são circunscritores socioinstitucionais que orientaram afetivamente movimentos no 
sistema de self - ofertaram fronteiras, mais ou menos flexíveis, para a localização dos jovens numa cultura religiosa.

Nos encontros entre o aspirante à vida religiosa consagrada e os circunscritores socioinstitucionais, a pessoa internaliza (ou não) valores e crenças ofertados naquele contexto. Assim, ocorre um movimento semiótico no sistema de self, possibilitando a criação de novos circunscritores pessoais que passarão a coordenar modos de ser e de sentir. Portanto, ao ser assumido pelos participantes como possível self, o desejo de ser padre, religioso ou religiosa consagrada funcionou como circunscritor pessoal na trajetória de vida dos sujeitos. Ao experienciarem ritos de passagem, como tornar-se coroinha, passar a receber acompanhamento vocacional ou direção espiritual, e vivenciar o postulantado, o noviciado, a vestição e a profissão temporária, os jovens negociaram reposicionamentos sociais e pessoais, criando uma versão singular do ser vocacionado à vida religiosa.

Ao longo de suas trajetórias de vida, os jovens construíram versões de si considerando constraints do aqui e agora, ou seja, versões que dialogavam com expectativas de uma realidade objetiva. Ao mesmo tempo, essa construção era projetada num horizonte futuro, exigindo um processo imaginativo na criação de uma nova versão de si (as-if). Esse processo, por sua vez, reposicionava as bordas dentro e entre os complexos semióticos, resultando na ampliação do sistema de self (as-is) da pessoa.

E, assim, os horizontes futuros poderiam ser ressignificados a cada experiência significativa, especialmente à medida que iam se tornando presentes, exigindo novos reposicionamentos sociais. Numa atitude reflexiva do sujeito, o sistema de self movimenta-se dialogicamente em direção ao futuro, criando ferramentas semióticas que auxiliam no cruzamento das bordas, localizando, de modo semiaberto, posições as-is e if-is.

\subsection{Devolutiva em processo aos participantes}

Conforme acordado no Termo de Consentimento Livre e Esclarecido, assinado pelos jovens e pelo pesquisador, uma última conversa foi realizada individualmente, no mês de fechamento da tese. A esse encontro chamei de "devolutiva em processo", quando foi possível, mais uma vez, ter os jovens como parceiros no desenvolvimento do estudo, podendo ouvi-los comentar e opinar sobre as informações construídas acerca de suas participações na pesquisa.

Acredito que a devolutiva em processo é parte importante na metodologia de estudos longitudinais que focam o desenvolvimento do self. Ela nos possibilita uma avaliação em processo, 
junto ao participante e, quando necessário, ajustamentos de possíveis equívocos na interpretação de fatos narrados em entrevistas.

$\mathrm{Na}$ presente pesquisa, em especial, a devolutiva em processo também teve o papel de certificar junto aos jovens as informações sobre suas histórias de vida e relações institucionais, narradas em situação de entrevista. Considerando o compromisso ético da pesquisa e sua necessária preocupação em não prejudicar os participantes, não podemos ignorar que estudamos jovens em formação em um contexto marcado por hierarquias. Muitas vezes, ao ser entrevistado o participante tece comentários que, a depender da forma como são apresentados, podem causar desconforto aos mesmos. Digo isso pelo fato de que, ao final da pesquisa, tínhamos o compromisso com uma devolutiva do estudo às instituições das quais os jovens pertenciam e, em geral, os formadores conhecem a história de vida do formando, o que facilitaria a identificação do mesmo, apesar dos nomes serem fictícios. Assim, por um lado a devolutiva em processo poderia colaborar com a qualidade das informações e, por outro, evitar desconforto aos participantes.

No segundo semestre de 2016, os quatro participantes estavam a morar em estados diferentes, por isso, o encontro presencial só foi possível com a Cecília, o qual teve duração de 1:20h. A devolutiva para os demais jovens foi realizada via Skype, tendo duração média de 1:30h. E com cada um eu limitei a falar apenas sobre sua participação no estudo, não aprofundando análises sobre os outros jovens.

Basicamente a conversa seguiu o mesmo padrão com os quatro participantes: inicialmente fiz um panorama dos fundamentos teóricos que orientaram os objetivos do estudo; em seguida recapitulei a história de vida do participante, resgatando informações sobre o ambiente familiar, as primeiras experiências no contexto da igreja, a aproximação e o ingresso na instituição religiosa, vivências ressaltadas nas entrevistas e expectativas em relação ao futuro. Em um terceiro momento expus o modo como foram organizadas as informações de pesquisa, destacando as marcas e signos hipergeneralizados direcionadores dos caminhos de análise, em cada caso. Por fim falei dos movimentos semióticos no sistema de self ao longo da trajetória de desenvolvimento daquele participante.

Em geral, os jovem ressaltaram a experiência de organizar narrativamente a própria história vocacional como um processo de autorreflexão e autoconhecimento. Três deles afirmaram que à medida que foram contando a história da sua vocação religiosa puderam pensar sobre várias situações e fatos vivenciados e sobre como eles se interligavam. Observaram que vários destes fatos e acontecimentos foram interpretados de modos diferentes ao longo de suas trajetórias de vida. Com isso conversamos como novas interpretações estão sempre em diálogo com futuros imaginados e/ou com interpretações antigas (reafirmadas ou abandonadas). O sujeito cria teias de significados mediadas por realidades sócio-históricas, em diálogo com a expectativa de um vir a 
ser. Assim, "temos uma história porque fazemos a narrativa de nossa vida" (Delory-Momberger, 2008, p. 37).

À medida que eu recapitulava a história dos participantes, eles se diziam surpresos com a quantidade de informações que relataram nas entrevistas. Caracterizavam como interessante a experiência de ouvir a própria história contada por um terceiro, um conhecido de poucos meses. Dois deles afirmaram que, com o tempo foram ficando mais à vontade para conversarem com o pesquisador, devido à confiança que se foi construindo na relação. Tal fato reforça a importância do cuidado que se deve ter na criação de um ambiente propício à negociação de significados em situação de entrevista. Seja o estudo longitudinal ou não, deve-se estar sempre atento à qualidade da interação pesquisador-pesquisando, e cuidar para que as interpretações do pesquisador não se sobreponham às construções do próprio participante. Pode acontecer que apenas depois de vários minutos a entrevista alcance uma qualidade de negociação de informações realmente significativa para os objetivos do estudo. Atento a isso, quando necessário, o pesquisador deve retomar questões importantes e pouco aprofundadas que apareceram no início da entrevista.

Uma devolutiva em processo, além de cumprir compromissos éticos da pesquisa, se mostra importante na verificação de como os participantes se reconhecem nos resultados do estudo. Uma metodologia que pode ser expressiva no aprofundamento de estudos de caso, especialmente, em pesquisa qualitativa longitudinal. Um modo de proporcionar olhares mais amplos sobre os fenômenos, considerando não só a perspectiva do investigador, mas também a perspectiva dos participantes. Para tanto, é melhor que o pesquisador tenha tempo suficiente para reavaliar os resultados a partir dos comentários surgidos na devolutiva aos participantes. No caso do nosso estudo, este tempo foi um tanto curto, mas o suficiente para afirmar a importância de utilizarmos a devolutiva como possibilidade de enriquecermos os resultados dos estudos com seres humanos.

\section{CONSIDERAÇÕES FINAIS}

A presente pesquisa investigou movimentos semióticos no sistema de self de jovens em formação para a vida religiosa consagrada, focando a natureza afetivo-dialógica e semiótica dos processos de regulação e autorregulação do self. Acreditamos ter contribuído com o conhecimento no campo da psicologia cultural, oferecendo olhares mais dinâmicos sobre processos de desenvolvimento na juventude.

Nosso foco voltou-se aos movimentos semióticos que o sujeito realiza ao longo de sua trajetória de desenvolvimento, em diálogo com sistemas simbólicos ofertados pela cultura. 
Destacamos recursos simbólicos utilizados pela pessoa na orientação e no direcionamento dos processos de transição de desenvolvimento, que podem favorecer a emergência de novas possibilidades de ser e de sentir, construindo sentidos inéditos de si e do mundo.

O processo de análise das informações, que reservou especial atenção ao ponto de vista dos participantes, nos possibilitou propor o conceito teórico-analítico de Horizontes de Projeção do Self (HPS), um modelo abstrato que contribui na compreensão de como a orientação para o futuro integra o sistema de self. Esse conceito destaca a construção de significados na constituição da cultura e do sujeito, de modo a transcender as fronteiras do aqui e agora, incorporando o passado e o futuro no processo de desenvolvimento de signos reguladores dos modos de ser e sentir da pessoa.

Mediante uma metodologia qualitativa de corte idiográfico, foram analisados quatro estudos de caso, de que participaram jovens em formação para a vida religiosa consagrada de ambos os sexos, com idade entre 19 e 25 anos. A pesquisa empírica, que se caracteriza como um estudo longitudinal, foi desenvolvida especialmente mediante duas entrevistas com cada participante, com intervalo de quinze meses, em média, entre a primeira e a segunda entrevista. Os quatro jovens vivenciaram a etapa de formação intitulada noviciado no decorrer da pesquisa, sendo que apenas um deles, a Cecília, não chegou a professar os votos temporários antes da segunda entrevista.

O processo de análise e discussão dos resultados buscou compreender como as informações da pesquisa dialogavam com os fundamentos da psicologia cultural, considerando os objetivos do estudo. Por isso, na organização da análise destacamos: esferas de experiência (caso Cecília), recursos simbólicos (caso Fátima), tensões dialógicas (caso Francisco) e futuro como elemento em aberto e partícipe do presente (caso Vicente). Consideramos esses elementos importantes na discussão de processos de transição de desenvolvimento. São dimensões presentes, de modo singular, na trajetória de vida dos quatro participantes; porém, cada um deles, ora mais, ora menos, destacou alguma dessas dimensões no arranjo de suas narrativas, o que também foi considerado por nós na organização e discussão das informações de pesquisa.

Com as análises aqui realizadas, pudemos chegar a algumas conclusões:

1. Ao vivenciarem processos de transição espacial e pessoal, os jovens deparam com tensões dialógicas entre as significações de si e as significações que as esferas de experiência ofertam como modos de ser e de sentir. Tais desafios disparam processos afetivos que colocam em diálogo experiências vividas e imaginadas, de modo a facilitar, ou não, o desenvolvimento na busca da construção de sentido de continuidade de si.

2. Nesse processo, os Horizontes de Projeção de Self desempenham papel fundamental na ampliação das fronteiras do sistema de self. De tal modo, 
3. A condição juvenil, como um conjunto de processos socialmente construído, deve ser pensada na consideração das bordas (mais ou menos flexíveis) dos contextos socioculturais em diálogo com os horizontes de possibilidades negociados entre sujeito e contexto.

4. Destarte, a passagem da condição de jovem para a condição de adulto está na interdependência de esferas de experiências com recursos simbólicos ofertados e interpretados de modo singular pelo sujeito.

5. As práticas sociais recortam determinadas possibilidades de trajetórias de desenvolvimento, destacando algumas e deixando outras em segundo plano. Tais recortes, situados política, social e culturalmente, podem integrar o sistema de self da pessoa, que de maneira dinâmica passa a projetar novas imagens no seu horizonte de futuro.

6. E esses são processos generalizáveis que, uma vez pensados em diálogo com processos típicos de determinado momento da vida, como a juventude e a adolescência, devem ser considerados sempre nos seus aspectos sociológicos e, também, psicológicos, sendo esta última a ênfase dada por este estudo.

Apesar de privilegiar um tempo ontogenético do desenvolvimento, esta pesquisa também buscou considerar processos afetivo-semióticos construídos em contextos específicos, como o familiar, o escolar, o religioso e o do grupo de pares. Issopossibilitou uma discussão entre esferas de experiência (nível mesogenético) e significados construídos de modo individual por participante (nível microgenético). Entretanto, mesmo pertencendo a institutos de vida consagrada diferentes, os jovens seguiam orientações institucionais similares, como percebemos nas citações do Código de Direito Canônico. Logo, podemos afirmar que a pesquisa ofereceu um olhar abrangente do desenvolvimento nos níveis macro, meso e ontogenético.

De tal modo, destacamos a importância de discutir processos afetivo-semióticos em diálogo com HPS na juventude, considerando diferentes níveis de inserção da pessoa. Os jovens na contemporaneidade, em geral, estão plugados a distintas realidades sociais e simbólicas, o que amplia possibilidades de novos significados na construção de trajetórias de desenvolvimento.

Cecília, Francisco, Fátima e Vicente nos proporcionaram um olhar mais dinâmico sobre o ser jovem na contemporaneidade. Há várias formas de ser jovem, há diferentes maneiras de ser vocacionado, e é possível construir trajetórias religiosas singulares. Mesmo que uma esfera de experiência oferte e priorize sistemas simbólicos que devem ser traduzidos em posturas, emoções, posicionamentos, modo de vestir, pensar e agir, os encontros entre recursos simbólicos, sóciohistoricamente construídos, e complexos semióticos (re)construídos ao longo da trajetória de vida podem ser sínteses sempre inéditas.

Conforme acordado no Termo de Consentimento Livre e Esclarecido, assinado pelos jovens e pelo pesquisador, uma última conversa foi realizada individualmente, no mês de 
fechamento da tese. Com a Cecília foi possível um encontro presencial, com duração de 1:20h. Com os demais a devolutiva foi via Skype, tendo duração média de 1:30h.

$\mathrm{Na}$ oportunidade foi relatado o processo de construção das análises, ressaltando os movimentos semióticos no sistema de self ao longo da trajetória de desenvolvimento dos jovens. Com isso, buscou-se, novamente, tê-los como parceiros na pesquisa e cada um pôde comentar e opinar sobre as informações construídas relacionadas à sua participação no estudo.

Em seus comentários os jovens ressaltaram a experiência de organizar narrativamente a própria história vocacional, vendo neste processo um momento de reflexão e autoconhecimento. Três deles afirmaram que com o tempo foram ficando mais à vontade para conversarem com o pesquisador, devido a confiança que se foi construindo. O que nos leva a refletir sobre o cuidado que se deve ter na criação de um ambiente propício à negociação de significados em situação de entrevista.

Essa devolutiva "em processo", além de cumprir compromissos éticos da pesquisa, se mostrou importante na verificação de como os jovens se reconheciam nos resultados do trabalho. Uma metodologia que pode ser expressiva no aprofundamento de estudos de caso, especialmente, em pesquisa qualitativa longitudinal. Um modo de proporcionar olhares mais amplos sobre os fenômenos, considerando não só a perspectiva do investigador, mas também a perspectiva dos participantes. 


\section{REFERÊNCIAS}

Abad, M. (2003). Crítica política às políticas de juventude. In M. V. Freitas, \& F. C. Papa (Orgs.), Políticas públicas: juventude em pauta (pp. 13-32). São Paulo: Cortez.

Abbey, E. (2012). Ambivalences and its transformations. In J. Valsiner (Org.), Oxford handbook of cultural psychology (pp. 989-997). Oxford: Oxford University Press.

Abramo, H. W. (2005). Condição juvenil no Brasil contemporâneo. In H. W. Abramo, \& P. P. M. Branco (Orgs.), Retratos da juventude brasileira: análise de uma pesquisa nacional (pp. 37-72). São Paulo: Fundação Perseu Abramo.

Amatuzzi, M. M. (1997). A experiência religiosa: uma pesquisa em andamento. A Psicologia e o Senso Religioso: anais do seminário. Ribeirão Preto.

Amatuzzi, M. M. (2005). Psicologia e espiritualidade. São Paulo: Paulus.

Araújo, C. M. (2008). Significações sobre adolescência e desenvolvimento humano em um projeto social educativo (Dissertação de mestrado). Instituto de Psicologia, Universidade de Brasília, Brasília, DF.

Araújo, C. M., \& Lopes de Oliveira, M. C. S. (2010). Significações sobre desenvolvimento humano e adolescência em um projeto socioeducativo. Educação em Revista, 26(3), 169-194.

Araújo, C. M., \& Lopes de Oliveira, M. C. S. (2013). Contribuições de Bourdieu ao tema do desenvolvimento adolescente em contexto institucional socioeducativo. Revista Pesquisas e Práticas Psicossociais, 8(2), 215-224.

Ávila, A. (2003). Para conhecer a psicologia da religião. São Paulo: Loyola.

Bakhtin, M. (1981). Discourse in the novel (C. Emerson \& M. Holquist, trads.). In M. Holquist (Ed.), The dialogic imagination: four essays (pp. 259-422). Austin: University of Texas Press. (Original publicado em 1934)

Bakhtin, M. (1984). Problems of Dostoevky's poetics (C. Emerson, trad.). Mineapolis, MN: University of Minnesota Press. (Original publicado em 1929 e revisto em 1963)

Bakhtin, M. (1988). Marxismo e filosofia da linguagem. São Paulo: Hucitec.

Bakhtin, M. (1992). Estética da criação verbal. São Paulo: Martins Fontes.

Bakhtin, M. (1997). Estética da criação verbal. São Paulo: Martins Fontes. (Original publicado em 1936)

Bakhtin, M. (2008). Problemas da poética de Dostoiévski. Rio de Janeiro: Forense Universitária. (Originalmente publicado em 1936)

Baptista, A. S. D. (2004). Estudo sobre as práticas religiosas e sua relação com a saúde mental de idosos: um estudo na comunidade. São Paulo: s.n. 
Bertau, M. C., \& Gonçalves, M. (2007). Looking at "meaning as movement" in development: Introductory reflections on the developmental origins of the dialogical self. International Journal for Dialogical Science, 2(1), 1-13.

Boesch, E. E. (1997). Reasons for a symbolic concept of action. Culture \& Psychology, 3(3), 423431.

Bolívar, A. (2001). Profissão professor: o itinerário profissional e a construção da escola. Porto Alegre: EDIPUCRS.

Branco, A. U. (2005). Peer interactions, language development and metacommunication. Culture \& Psychology, 11(4), 415-429.

Branco, A. U. (2006). Crenças e práticas culturais: co-construção e ontogênese de valores sociais. Revista Pro-Posições, 17(2), 139-155.

Branco, A. U. (2015). Values and their ways of guiding the psyche. In J. Valsiner; G. Marsico; N. Chaudhary; T. Sato \& v. Dazzani (Eds.), Psychology as the Science of human being: the Yokohama Manifesto (pp. 225-244). Cham, Switzerland: Springer.

Branco, A. U., \& Mettel, T. P. L (1995). O processo de canalização cultural das interações criançacriança na pré-escola. Psicologia: Teoria e Pesquisa, 11(1), 13-22.

Branco, A. U., \& Rocha, R. F. (1998). A questão da metodologia na investigação científica do desenvolvimento humano. Psicologia: Teoria e Pesquisa, 14(3), 251-258.

Branco, A. U., \& Valsiner, J. (1997). Changing methodologies: a co-constructivist study of goal orientations in social interactions. Psychology and Developing Societies, 9(1), 35-64.

Brandão, C. R. (2004). Fronteira da fé - alguns sistemas de sentido, crenças e religiões no Brasil de hoje. Estudos Avançados, 18(52), 261-288.

Brannon, L., \& Feist, J. (2001). Psicología de la salud. Madrid: Paraninfo Thomson Learning.

Bronfenbrenner, U. (1996). A Ecologia do desenvolvimento humano. Porto Alegre: Artes Médicas.

Bruner, J. (1987). Life as narrative. Social Research, 54(1), 11-32.

Bruner, J. (1997). Atos de significação (S. Costa, trad.). Porto Alegre: Artes Médicas. (Original publicado em 1990)

Bruner, J. (2001). A cultura da educação. Porto Alegre: Artmed.

Bruner, J. S. (2002). Realidade mental, mundos possíveis. Porto Alegre: Artmed.

Bruner, J. (2004). Life as narrative. Social Research, 71(3), 691-710.

Bruner, J. S., Goodnow, J. J., \& Austin, G. A. (1956). A study of thinking. Nova York: Wiley.

Calvetti, P. Ü., Muller, M. C., \& Nunes, M. L. T. (2008). Qualidade de vida e bem-estar espiritual em pessoas que vivem com HIV/Aids. Psicologia em Estudo, 13(3), 523-530.

Camarano, A. A., Mello, J. L., \& Kanso, S. (2006). Do nascimento à morte: principais transições. In A. A. Camarano (Org.), Transição para a vida adulta ou vida adulta em transição? (pp. 31-60). Rio de Janeiro: Ipea. 
Camboim, A., \& Rique, J. (2010). Religiosidade e espiritualidade de adolescentes e jovens adultos. Revista Brasileira de História das Religiões, 3(7), 251-263.

Código de Direito Canônico (1983). São Paulo: Edições Loyola.

Cole, M. (1995). Culture and cognitive development: from cross-cultural research to creating systems of cultural mediation. Culture \& Psychology, 1(1), 25-54.

Cole, M. (1996). Cultural psychology: a once and future discipline. Cambridge, MA: Belknap.

Cole, M., \& Cole, S. R. (2004). O desenvolvimento da criança e o do adolescente. Porto Alegre: Artmed.

Connelly F. M., \& Clandinin, J. (1990). Stories of experience and narrative inquiry. Educational Researcher, 5(19), 2-14.

Correia, M. F. B. (2003). A constituição social da mente: (re)descobrindo Jerome Bruner e construção de significados. Estudos de Psicologia, 8(3), 505-513.

Cunha, C., Salgado, J., \& Gonçalves, M. (2012). The dialogical self in movement: Narrating a method to capture the dynamics of change and stability in the self. In E. Abbey \& S. Surgan (Eds.), Developing methods in psychology (pp. 65-100). New Brunswick, NJ: Transaction Publishers.

Dalgalarrondo, P. (2006). Relações entre duas dimensões fundamentais da vida: saúde mental e religião. Revista Brasileira de Psiquiatria, 28(3), 177-178.

Dalgalarrondo, P. (2008). Religião, psicopatologia e saúde mental. Porto Alegre: Artmed.

Davies, B., \& Harré, R. (1990). Positioning: the discursive production of selves. Journal for the Theory of Social Behavior, 20(1), 43-63.

Dayrell, J. (2007). A escola "faz" as juventudes? Reflexões em torno da socialização juvenil. Educação e Sociedade, 28(100), 1105-1128.

Dayrell, J., Carrano, P., \& Maia, C. L. (Orgs.) (2014). Juventude e ensino médio: sujeitos e currículos em diálogo. Belo Horizonte: Editora UFMG.

De la Mata, M. L., \& Cubero, M. (2003). Psicología cultural: aproximaciones al estudio de la relación entre mente y cultura. Infancia y Aprendizaje, 26(2), 181-199.

Del Río, P., \& Álvarez, A. (2007). De la psicología del drama al drama de la psicología: la relación entre la vida y la obra de Lev S. Vygotski. Estudios de Psicología, 28(3), 303-332.

Delory-Momberger, C. (2008). Biografia e educação: figuras do indivíduo-projeto. (M. C. Passegi, J. F. S. Neto, \& L. Passegi, trad.) São Paulo: Paulus.

Denzin, N. K., \& Lincoln, Y. S (2006). O planejamento da pesquisa qualitativa: teorias $e$ abordagens. Porto Alegre: Artmed.

Dominguez, M. (2013). Do sistema à ação, do homogêneo ao heterogêneo: movimentos fundantes dos conceitos de dialogismo, polifonia e interdiscurso. Bakhtiniana, 8(1), 5-20. 
Elder, G. H., \& Shanahan, M. J. (2006). The life course and human development. In W. Damon \& R. M. Lerner (Orgs.), Handbook of child psychology (v. 1, Theoretical modes of human development, pp. 664-715). Hobke-NJ: Wiley \& Sons.

Esteban-Guitart, M. (2008). Hacia una psicología cultural: origen, desarrollo y perspectivas. Fundamentos em Humanidades, 18(2), 7-23.

Fabrega, H. (2000). Culture, spirituality and psychiatry. Current Opinion in Psychiatry, 13, 525-30.

Faria, J., \& Seidl, E. (2005). Religiosidade e enfrentamento em contextos de saúde e doença: revisão da literatura. Psicologia: Reflexão e Crítica, 18(3), 381-389.

Fernandes, M. A. (2015). Fenomenologia da facticidade da vida religiosa cristã desde o Novo Testamento: mundo, si-mesmo, temporalidade. Revista Brasileira de Filosofia da Religião, 2(2), 14-34.

Ferreira, T., Salgado, J., \& Cunha, C. (2006). Ambiguity and the dialogical self: in search for a dialogical self. Estudios de Psicología, 27(1), 19-32.

Figueira, E. A. P. (2007). Experiência religiosa e experiência humana no séc. XXI: construção de chaves de leitura para estudo do fato religioso. Revista Nures, 3(7), 1-20.

Filoramo, G., \& Prandi, C. (1999). As ciências das religiões. São Paulo: Paulus.

Fleck, M., Borges, Z., Bolognesi, G., \& Rocha, N. S. (2003). Desenvolvimento do Whoqol, módulo espiritualidade, religiosidade e crenças pessoais. Revista de Saúde Pública, 37(4), 446-455.

Flick, U. (2004). Uma introdução à pesquisa qualitativa. Porto Alegre: Artmed.

Flick, U., von Kardorff, E., \& Steinke, I. (2000). Was its qualitative Forschung? Einleitung und Überblick. [O que é pesquisa qualitativa? Uma introdução]. In U. Flick, E. von Kardorff, \& I. Steinke (Orgs.), Qualitative Forschung: Ein Handbuch [Pesquisa qualitativa: um manual] (pp. 13-29). Reinbek: Rowohlt.

Fogel, A. (1993). Developing through relationships: origins of communication, self and culture. Hertfordshire: Harvester Wheatsheaf.

Fogel, A., \& Garvey, A. (2007). Alive communication. Infant Behavior and Development, 30, 250257.

Fogel, A., Koeyer, I., Bellagamba, F., \& Bell, H. (2002). The dialogical self in the first two years of life: embarking on a journey of discovery. Theory and Psychology, 12(2), 191-205.

Freire, S. F. C. D. (2008). Concepções dinâmicas de si de crianças em escolarização: uma perspectiva dialógico-desenvolvimental (Tese de doutorado). Instituto de Psicologia, Universidade de Brasília, Brasília, DF.

Freitas, M. T. A. (1996). Bakhtin e a psicologia. In C. A. Faraco, C. Tezza, \& G. de Castro, Diálogos com Bakhtin (pp. 165-187). Curitiba: Editora da UFPR.

Freitas, M. T. A. (2002). A abordagem sócio-histórica como orientadora da pesquisa qualitativa. Cadernos de Pesquisa, 116, 21-39. 
Furstenberg, F. F., Rumbaut, R. G., \& Settersten, R. A. (2005). On the frontier of adulthood: emerging themes and new directions. In R. A. Settersten, R. G. Rumbaut, \& F. J. Furstenberg (Orgs.), On the frontier of adulthood: theory, research and public policy (pp. 23-53). Chicago: University of Chicago.

Garvey, A. P. (2014). Emoções e comunicação como um sistema dinâmico: abordagem históricorelacional. In M. C. D. P Lyra, A. P Garvey, M. Silva \& E. C. Chaves (Orgs.), Microgênese: estudo do processo de mudança (pp. 21-51). Recife: UFPE.

Geertz, C. (1978). A interpretação das culturas. Rio de Janeiro: Zahar.

Gergen, K. J. (1985). The social constructionist movement in modern psychology. American Psychologist, 40(3), 266-275.

Germano, I., \& Bessa, L. L. (2010). Pesquisas narrativo-dialógicas no contexto de conflito com a lei: considerações sobre uma entrevista com jovem autora de infração. Revista Mal-Estar e Subjetividade, $X(3), 995-1033$.

Godinho, D. M. S. (2007). Paradigmas do religioso entre os jovens contemporâneos (Dissertação de mestrado). Pontifícia Universidade Católica do Rio de Janeiro, Rio de Janeiro.

Gomes, R. S. (2010). A festa do boi-Bumbá no Amazonas: instrumento pedagógico na composição e manutenção da identidade cultural do jovem amazônico (Dissertação de mestrado). Pontifícia Universidade Católica de Goiás, Goiânia.

Gonçalves, M., \& Ribeiro, A. (2012). Narrative processes of innovation and stability within the dialogical self. In H. J. M. Hermans \& T. Gieser (Eds.), Handbook of dialogical self theory (pp. 310-318). Cambridge: Cambridge University Press.

Gonçalves, M., \& Salgado, J. (2001). Mapping the multiplicity of the self. Culture \& Psycology, 7(3), 367-377.

González Rey, F. (1998). Lo cualitativo y lo cuantitativo en la investigación de la psicología social. Psicologia \& Sociedade, 10(2), 32-52.

González Rey, F. (1999). La investigación cualitativa en psicología: rumbos y desafios. São Paulo: Educ.

González Rey, F. (2002). Pesquisa qualitativa em psicologia: caminhos e desafios. São Paulo: Thomson.

Goolishian, H. A., \& Anderson, H. (1996). Narrativa e self: alguns dilemas pós-modernos da psicolterapia. In D. F. Schnitman (Org.), Novos paradigmas, cultura e subjetividade (pp. 191-199). Porto Alegre: Artes Médicas.

Granatella, M.-G. (2015). Imaginative universals and human cognition in the new science of Giambattista Vico. Culture \& Psychology, 21(2), 185-206.

Günther, H. (2006). Pesquisa qualitativa versus pesquisa quantitativa: esta é a questão? Psicologia: Teoria e Pesquisa, 22(2), 201-210. 
Hall, S. (2002). Identidade cultural na pós-modernidade. Rio de Janeiro: DP\&A.

Halliday, M.A.K., \& Hasan, R. (1989). Language, context and text: aspects of language in a social-semiotic perspective. Oxford: Oxford University Press.

Henning, M. C., \& Moré. C. L. O. O. (2009). Religião e psicologia: análise das interfaces temáticas. Revista de Estudos da Religião, 9(4), 84-114.

Hermans, H. J. M. (2002). The dialogical self as a society of mind: an introduction. Theory and Psychology, 12(2), 147-160.

Hermans, H. J. M.; Kempen, H. J. G. (1993). The dialogical self: meaning as movement. San Diego, CA: Academic Press.

Hermans, H. J. M., Kempen, H. J. G., \& van Loon, R. (1992). The dialogical self: beyond individualism and rationalism. American Psychologist, 47(1), 23-33.

Josephs, I. E. (2002). 'The hopi in me': the construction of a voice in the dialogical self from a cultural psychological perspective. Theory \& Psychology, 12(2), 161-173.

Jung, C. G. (1978). Psicologia e religião. Rio de Janeiro: Vozes.

Kitayama, S., \& Cohen, D. (2007). Handbook of cultural psychology. New York: Guilford.

Lacasa, P., Del Castillo, H., \& García-Varela, A. B. (2005). A bakhtinian approach to identity in the context of institutional practices. Culture \& Psychology, 11(3), 287-308.

Leão, G., Dayrell, J. T., \& Reis, J. B. (2011). Jovens olhares sobre a escola do ensino médio. Cadernos Cedes, 31(84), 253-273.

León, O. D. (2009). Uma revisão das categorias de adolescência e juventude. In M. T. C. Guimarães, \& S. M. G. Sousa (Orgs.), Juventude e contemporaneidade: desafios e perspectivas (pp. 46-76). Goiânia: Editora UFG.

Levi, G., \& Schmitt, J. C. (1996). História dos jovens 1: Da Antiguidade Clássica à era moderna. São Paulo: Companhia das Letras.

Lewis, M. C. (2002). The dialogical brain: contributions of emotional neurobiology to understanding the dialogical self. Theory \& Psychology, 12(2), 175-190.

Lopes de Oliveira, M. C. S. (2006). Identidade, narrativa e desenvolvimento na adolescência: uma revisão crítica. Psicologia em Estudo, 11(2), 427-436.

Lopes de Oliveira, M. C. S. (2013). The baktinian self and beyond: Towards a dialogical phenomenology of the self. Culture \& Psychology, 19, 259-272.

Lopes de Oliveira, M. C. S. (2016). Desenvolvimento do self e processos de hiperindividualização: interrogações à psicologia dialógica. Psicologia USP, 27(2), 201-211.

Lukas, E. (2002). Psicologia espiritual. Rio de Janeiro: Vozes.

Lyra, M. C. D. P. (2000). Desenvolvimento como processo de mudança em um sistema de relações historicamente construído: contribuições do estudo da comunicação no início da vida. Reflexão e Crítica, 13(2), 257-268. 
Lyra, M. C. D. P. (2006). O modelo EEA para a investigação da emergência e desenvolvimento da comunicação e do self: bases conceituais e fundamentos teórico-metodológicos. Estudos de Psicologia, 11(1), 25-33.

Lyra, M. C. D. P. (2007). O modelo EEA: definições, unidade de análise e possíveis aplicações. Psicologia, Reflexão e Crítica, 20(1), 87-95.

Macedo, L. S. R., \& Silveira, A. C. (2012). Self: um conceito em desenvolvimento. Paidéia, 22(52), 281-289.

Macmillan, R. (2006). Constructing adulthood: agency and subjectivity in the transition to adulthood. In R. Macmillan (Org.), Constructing adulthood: agency and subjectivity in adolescence and adulthood (Advances in Life Course Research, 11, pp. 3-29). London: Elsevier.

Madureira, A. F. A., \& Branco, A. U. (2001). A pesquisa qualitativa em psicologia do desenvolvimento: questões epistemológicas e implicações metodológicas. Temas em Psicologia, 9(1), 63-75.

Madureira, A. F. A., \& Branco, A. U. (2005). Construindo com o outro: uma perspectiva sociocultural construtivista do desenvolvimento humano. In M. A. Dessen, \& A. L. Costa Júnior (Orgs.), A ciência do desenvolvimento humano: tendências atuais e perspectivas futuras (pp. 90-109). Porto Alegre: Artmed.

Marková, I. (2003). Dialogicality and social representations: the dynamics of mind. Cambridge: Cambridge University Press.

Markus, H. R., \& Nurius, P. (1986). Possible selves. American Psychologist, 41(9), 954-969

Martins, D. S. M., \& Carvalho, C. (2013). Identidade vocacional de jovens institucionalizados em centros educativos: um olhar na (re)educação em Portugal. Revista Eletrônica de Educação, 7(3), 25-39.

Mattos, E. (2013). Desenvolvimento do self na transição para a vida adulta: um estudo longitudinal com jovens baianos (Tese de doutorado). Universidade Federal da Bahia, Salvador-Bahia.

Mattos, E., \& Chaves, A. (2013). The architecture of self-in-motion: Exploring young people's construction of "becoming". Interacções, 24, 106-136.

McAdams, D. P. (2001). The psychology of life stories. Review of General Psychology, 5(2), 100122.

Merleau-Ponty, M. (1991). Os signos. São Paulo: Martins Fontes.

Michel, A. A., \& Wortham, S. E. F. (2002). Clearing away the self. Theory \& Psychology, 12(5), 625-650.

Mortimer, J. T. (2003). Working and growing up in America. Cambridge: Harvard University Press. 
Murray, M. (2008). Narrative psychology. In J. A. Smith (Org.), Qualitative psychology: a practical guide to research methods (pp. 111-132). Los Angeles, CA: Sage.

Noé, S. V. (2010). A vocação sublime: da relação entre religião e sublimação na definição da vocação religiosa. Psicologia USP, 21(1), 165-182.

Nogueira, M. E. O., \& Lemos, S. M. L. (2013). Tecendo o fio de ouro: Itinerário para o autoconhecimento e a liberdade interior. Aquiraz: Edições Shalom.

Novaes, R. (2004). Os jovens "sem religião": ventos secularizantes, "espírito de época" e novos sincretismos. Notas preliminares. Estudos Avançados, 18(52), 321-330.

Ozella, S. (2003). Adolescências construídas: a visão da psicologia sócio-histórica. São Paulo: Cortez.

Padilha, M. (2010). Negritude e infância: cultura, relações étnico-raciais e desenvolvimento de concepções de si em crianças. Dissertação de Mestrado, Instituto de Psicologia, Universidade de Brasília.

Paiva, G. J. (1998). Estudos psicológicos da experiência religiosa. Temas em Psicologia, 6(2), 153160.

Paiva, G. J. (2004). Espiritualidade e qualidade de vida: pesquisas em psicologia. In E. F. B. Teixeira, M. C. Muller, \& J. D. T. Silva (Orgs.), Espiritualidade e qualidade de vida (pp. 119-130). Porto Alegre: EDIPUCRS.

Paiva, G. J. (2007). Religião, enfrentamento e cura: perspectivas psicológicas. Estudos de Psicologia, 24(1), 99-104.

Paiva, I. L., Bezerra, M. A., Silva, G. S. N., \& Nascimento, P. D. (Orgs.) (2013). Infância e juventude em contextos de vulnerabilidades e resistências. São Paulo: Zagodoni.

Palmieri, M. W. A., \& Branco, A. U. (2004). Cooperação, competição e individualismo em uma perspectiva sócio-cultural construtivista. Psicologia: Reflexão e Crítica, 17(2), 189-198.

Peirce (1955). Philosophical Writings of Peirce, edited by Justus Buchler. New York: Dover.

Pereira, A. (2007). Fenomenologia da experiência religiosa: reflexão acerca da sua possibilidade e sentido. Recuperado de http://www.lusosofia.net/textos/americo_pereira_fenomenologia_experiencia_religiosa.pdf

Peres, F., Simão, M., \& Nasello, A. (2007). Espiritualidade, religiosidade e psicoterapia. Revista de Psiquiatria Clínica, 34(1), 136-145.

Pérez, M. C., \& Santigosa, A. (2005). Psicología cultural: una aproximación conceptual e histórica al encuentro entre mente y cultura. Avances en Psicología Latinoamericana, 23, 15-31.

Pern, T. (2015). Imagination in Vico and Hobbes: From affective sensemaking to culture. Culture \& Psychology, 21(2), 162-184.

Pinto, Ê. B. (2009). Espiritualidade e religiosidade: articulações. Revista de Estudos da Religião, 9, 68-83. 
Pires, S. F. S., \& Branco, A. U. (2008). Cultura, self e autonomia: bases para o protagonismo infantil. Psicologia: Teoria e Pesquisa, 24(4), 415-421.

Rogoff, B. (1998). Observando a atividade sociocultural em três planos: apropriação participatória, participação guiada e aprendizado. In J. V. Wertsch, P. del Rio, \& L. Alvarez (Orgs.), Estudos socioculturais da mente (pp. 123-142). Porto Alegre: Artmed.

Rogoff, B. (2003). The cultural nature of human development. New York: Oxford University Press.

Rogoff, B., \& Chavajay, P. (1995). What's become of research on the cultural basis of cognitive development. American Psychologist, 50, 859-877.

Roncancio Moreno (2015). Dinâmica das significações de si em crianças na perspectiva dialógicocultural (Tese de doutorado). Instituto de Psicologia, Universidade de Brasília, Brasília, DF.

Rosa, A. (2000). Entre la explicación del comportamento y el esfuerzo por el significado: una mirada al desarrollo de las relaciones entre el comportamento individual y la cultura. Revista de Historia de la Psicología, 21(4), 77-114.

Rosa, C., \& Gonçalves, M. M. (2013). Estratégias dialógicas de auto-organização da identidade: psicoterapia e reestruturação da gestão interna. Psicologia: Teoria e Pesquisa, 29(3), 305312 .

Salgado, J. M. C. F., \& Ferreira, T. B. S. (2012). Educação para a paz: uma perspectiva dialógica. In A. M. C. U. Branco, \& M. C. Lopes de Oliveira (Orgs.), Diversidade e cultura da paz na escola: contribuições da perspectiva sociocultural (pp. 51-65). Porto Alegre: Mediação.

Salgado, J., \& Gonçalves, M. (2007). The dialogical self: social, personal and (un)conscious. In J. Valsiner \& A. Rosa (Eds.), The Cambridge Handbook of Sociocultural Psychology (pp. 608-621). New York: Cambridge University Press.

Santos, J. E. F., \& Bastos, A. C. S. (2012). Travessias: a adolescência em Novos Alagados: trajetórias pessoais e estruturas de oportunidade em um contexto de risco psicossocial. Revista Levs, 10, 256-272.

Santos, J. L. (1996). O que é cultura. São Paulo: Brasiliense.

Sato, T., Hidaka, T., \& Fukuda, M. (2009). Depicting the dynamics of living the life: the Trajectory Equifinality Model. In J. Valsiner, P. Molenaar, M. Lyra, \& N. Chaudhary (Orgs.), Dynamic process methodology and the social and developmental sciences (pp. 217-240). New York: Springer.

Serrano, J. (1996). La psicología cultural como psicología crítico-interpretativa. In A. Gordo, \& J. Linaza (Orgs.), Psicologías, discursos y poder (pp. 93-106). Madrid: Visor.

Shweder, R. A. (1990). Cultural psychology - what is it? In J. W. Stigler, R. A Shweder, \& G. Herdt (Orgs), Cultural psychology (pp. 1-43). Cambridge: Cambridge University Press. 
Simão, L. (2010). Ensaios Dialógicos: compartilhamento e diferença nas relações eu-outro. São Paulo: HUCITEC.

Simão, L. M. (2016). Culture as a Moving Symbolic Border. Integr Psych Behav 50, 14-28

Souza, C., \& Paiva, I. L. (2012). Faces da juventude brasileira: entre o ideal e o real. Estudos de Psicologia, 17(3), 353-360.

Sposito, M. P. (2005). Algumas reflexões e muitas indagações sobre as relações entre juventude e escola no Brasil. In H. W. Abramo, \& P. P. M. Branco (Orgs.), Retratos da juventude brasileira: análises de uma pesquisa nacional (pp. 87-128). São Paulo: Editora Fundação Perseu Abramo.

Stroppa, A., \& Moreira-Almeida, A. (2008). Religiosidade e saúde. In M. I. Salgado \& G. Freire (Orgs.), Saúde e espiritualidade: uma nova visão da medicina (pp. 427-443). Belo Horizonte: Inede.

Takeuti, N. M. (2012). Paradoxos societais e juventude contemporânea. Estudos de Psicologia, $17(3), 427-434$.

Tateo, L. (2015a). Giambattista Vico and the principles of cultural psychology: A programmatic retrospective. History of the Human Sciences, 28(1) 44-65.

Tateo, L. (2015b). Giambattista Vico and the psychological imagination. Culture \& Psychology, 2l(2) 145-161.

Tateo, L. (2016). Giambattista Vico and the new psychological science. New Brunswick, NJ: Transaction.

Valle, E. R. (1998). Psicologia e experiência religiosa. São Paulo: Loyola.

Valsiner, J. (1987). Culture and the development of children's actions. Great Britain: John Wiley.

Valsiner, J. (1989). Human development and culture: the social nature of personality and its study. Lexington: Lexington Books.

Valsiner, J. (1997). Culture and the development of children"s actions: a theory of human development. New York: Wiley.

Valsiner, J. (1998). The guided mind. Cambridge: Harvard University Press.

Valsiner, J. (2000). Culture and human development. London: Sage.

Valsiner, J. (2002). Forms of dialogical relations and semiotic autoregulation within the self. Theory \& Psychology, 12(2), 251-264.

Valsiner, J. (2004). Three years later: culture in psychology — between social positioning and producing new knowledge. Culture \& Psychology, 10(1), 5-27.

Valsiner, J. (2006). Developmental epistemology and implications for methodology. In W. Damon, \& R. Lerner (Orgs.), Handbook of child psychology (pp. 166-208). Hobke-NJ: Wiley \& Sons. 
Valsiner, J. (2007). Culture in minds and societies: foundations of cultural psychology. London: Sage.

Valsiner, J. (2008). Open intransitivity cycles in development and education: pathways to synthesis [Versão eletrônica]. European Journal of Psychology of Education, 23(2), 131-147.

Valsiner, J. (2009). Cultural psychology today: innovations and oversights. Culture \& Psychology, $15(1), 5-39$.

Valsiner, J. (2012). Fundamentos da psicologia cultural. Porto Alegre: Artmed.

Valsiner, J. (2012). The Oxford handbook of culture and psychology. NY: Oxford University Press.

Valsiner, J. (2014). An invitiation to cultural psychology. London: SAGE Publications Ltd.

Valsiner, J. \& Cairns, R. (1992). Theoretical perspectives on conflict and development. In C. V. Shantz, \& W. W. Hartup (Orgs.), Conflict in child and adolescent development (pp. 15-35). Cambridge: Cambridge University Press.

Valsiner, J., Branco, A. U., \& Melo Dantas, C. (1997). Co-construction of human development: heterogeneity within parental belief orientations. In D. Rudy \& J. E. Grusec, Understanding the transmission of values (pp. 283-304). New York: Wiley.

Valsiner, J., Marsico, G., Chaudhary, N., Sato, T., \& Dazzani, V. (2015) (Orgs). Psychology as the Science of Human Being: the Yokohama Manifesto. Cham, Switzerland: Springer.

Valsiner, J., \& Rosa, A. (2007). The myth, and beyond: ontology of psyche and epistemology of psychology. In J. Valsiner \& A. Rosa (Orgs.), The Cambridge handbook of sociocultural psychology (pp. 23-39). New York: Cambridge University Press.

Valsiner, J., \& Van Der Veer, R. (2000). The social mind: construction of the idea. Cambridge: Cambridge University Press.

Velho, A. P. M. (2009). A semiótica da cultura: apontamentos para uma metodologia de análise da comunicação. Revista de Estudos da Comunicação, 10(23), p. 249-257.

Vila, I. (2001). Lev S. Vigotsky: la psicología cultural y la construcción de la persona desde la educación. In J. Trilla (Org.). El legado pedagógico del siglo XX para la escuela del siglo XXI (pp. 207-228). Barcelona: Graó.

Vygotsky, L. S. (2000). A construção do pensamento e da linguagem. São Paulo: Martins Fontes.

Vygotsky, L. S. (2004). Imagination and creativity in childhood. Journal of Russian and East European Psychology, 42(1), 7-97.

Vygotsky, L. S. (2007). A formação social da mente. São Paulo: Martins Fontes.

Wertsch, J. V. (1991). Voices of the mind: a sociocultural approach to mediated action. Cambridge, Mass.: Harvard University Press.

Wertsch, J. V. (1998). Mind as action. New York: Oxford University Press.

Wertsch, J. V. \& Tulviste, P. (1994). Lev Semyonovich Vygotsky and contemporary developmental psychology. In R. D. Parke, P. A. Ornstein, J. J. Reiser, \& C. Zahn-Waxler 
(Orgs.). A century of developmental psychology (pp. 333-355).Washington: American Psychological Association.

Wiley, N. (1994). The semiotic self. Chicago: The University of Chicago Press. (Em português: Wiley, N. (1996). O self semiótico (L. P. Rouanet, trad.). São Paulo: Loyola.

Wortham, S. (2000). Interactional positioning and narrative self-construction. Narrative Inquiry, 10(1), 157-184.

Zittoun, T. (2006a). Transitions: development through symbolic resources. Charlotte, NC: Information Age.

Zittoun, T. (2006b). Transitions. Greenwich, CT: InfoAge.

Zittoun, T. (2007a). Symbolic resources and responsibility in transitions. Young: Nordic Journal of Youth Research, 15(2), 193-211.

Zittoun, T. (2007b). The symbolic resources in human lives. In J. Valsiner \& A. Rosa (Orgs.), Cambridge handbook of socio-cultural psychology (pp. 343-361). New York: Cambridge University Press.

Zittoun, T. (2012). On the emergence of the subject. Integrative Psychological and Behavioral Science, 46(3), 259-273.

Zittoun, T. (2015). From Vico to the sociocultural imagination. Culture \& Psychology, 21(2) 251258.

Zittoun, T., \& Grossen, M. (2012). Cultural elements as means of constructing the continuity of the self across various spheres of experience. In M. César. \&, B. Ligorio (Eds.), Interplays between dialogical learning and the dialogical self (pp. 99-126). NC: Information Age Publishing, IAP.

Zittoun, T., \& Perret-Clermont, A.-N. (2009). Four social psychological lenses for developmental psychology. European Journal for Psychology of Education, 24(2), 387-403. 


\section{ANEXOS}

\section{ANEXO I}

\section{Aceite Institucional}

$\mathrm{O}(\mathrm{A}) \mathrm{Sr} . / \mathrm{Sra}$. do(a) está de acordo com a realização da pesquisa "Transições de desenvolvimento da adolescência à juventude no campo da experiência vocacional religiosa: contribuições à psicologia dialógica"14, de responsabilidade do(a) pesquisador Cláudio Márcio de Araújo aluno de doutorado no Departamento de Psicologia Escolar e do Desenvolvimento, Instituto de Psicologia da Universidade de Brasília (PED/IP/UnB), realizado sob orientação da Professora $\operatorname{Dr}^{\mathrm{a}}$ Maria Claudia Santos Lopes de Oliveira, após revisão e aprovação pelo Comitê de Ética em Pesquisa do Instituto de Ciências Humanas da Universidade de Brasília - CEP/IH.

O estudo envolve a realização da produção de: 1 . uma narrativa escrita, na forma de uma história, sobre as experiências que os jovens consideram importantes no seu processo do reconhecimento de si como um(a) vocacionado(a) à vida religiosa; 2 . uma entrevista individual do tipo história de vida, focando sobre a trajetória como vocacionado(a) à vida religiosa; 3. uma segunda entrevista individual, do tipo episódica, para aprofundar informações referentes aos momentos anteriores da pesquisa; e 4. um último encontro, onde o pesquisador fará a devolutiva para cada um dos participantes individualmente, estabelecendo uma discussão sobre os resultados construídos no processo de investigação. A pesquisa terá a duração de 24 meses, com previsão de início em agosto de 2014. Portanto, os procedimentos acima mencionados serão desenvolvidos neste intervalo de tempo.

$\mathrm{Eu}$, do(a) declaro

conhecer e cumprir as Resoluções Éticas Brasileiras, em especial a Resolução CNS 196/96. Esta instituição está ciente de suas corresponsabilidades como instituição participante do presente 
projeto de pesquisa, e de seu compromisso no resguardo da segurança e bem-estar dos sujeitos de pesquisa nela recrutados, dispondo de infraestrutura necessária para a garantia de tal segurança e bem-estar.

Brasília, de de

Assinatura e carimbo do(a) responsável pela instituição 


\section{ANEXO II}

\section{Termo de Consentimento Livre e Esclarecido}

Você está sendo convidado a participar da pesquisa "Transições de desenvolvimento da adolescência à juventude no campo da experiência vocacional religiosa: contribuições à psicologia dialógica", de responsabilidade de Cláudio Márcio de Araújo, aluno de doutorado da Universidade de Brasília. O objetivo desta pesquisa é investigar a especificidade do papel da experiência religiosa/vocacional nos processos de desenvolvimento e transição da adolescência à condição de adulto jovem. Assim, gostaria de consultá-lo(a) sobre seu interesse e disponibilidade de cooperar com a pesquisa.

Você receberá todos os esclarecimentos necessários antes, durante e após a finalização da pesquisa, e lhe asseguro que o seu nome não será divulgado, sendo mantido o mais rigoroso sigilo mediante a omissão total de informações que permitam identificá-lo(a). Os dados provenientes de sua participação na pesquisa, tais como questionários, entrevistas, fitas de gravação ou filmagem, ficarão sob a guarda do pesquisador responsável pela pesquisa.

A coleta de dados será realizada por meio da: 1. produção de uma narrativa escrita, na forma de uma história, sobre as experiências que os jovens consideram importantes no seu processo do reconhecimento de si como um(a) vocacionado(a) à vida religiosa; 2. uma entrevista individual do tipo história de vida, focando sobre a trajetória como vocacionado(a) à vida religiosa; 3. uma segunda entrevista individual, do tipo episódica, para aprofundar informações referentes aos momentos anteriores da pesquisa; e 4. um último encontro, onde o pesquisador fará a devolutiva para cada um dos participantes individualmente, estabelecendo uma discussão sobre os resultados construídos no processo de investigação. É para um ou mais destes procedimentos que você está sendo convidado a participar. Em outras palavras, você participará do momento "1" e poderá ser convidado a participar dos demais momentos. Sua participação na pesquisa não implica em nenhum tipo de risco.

Espera-se com esta pesquisa compreender melhor processos de transição de desenvolvimento na adolescência e juventude, considerando o contexto da experiência religiosa. Assim, a pesquisa possibilitará olhar para os fenômenos adolescência e juventude como sendo constituídos na relação intrínseca entre pessoa e ambiente histórico-cultural.

Sua participação é voluntária e livre de qualquer remuneração ou benefício. Você é livre para recusar-se a participar, retirar seu consentimento ou interromper sua participação a qualquer momento. Sua participação em um dos procedimentos de coleta de dados não o(a) obriga a participar dos demais. A recusa em participar não irá acarretar qualquer penalidade ou perda de benefícios. 
Se você tiver qualquer dúvida em relação à pesquisa, você pode me contatar através do telefone 61-83208780 ou pelo e-mail claudioaraujo.filo@gmail.com

Eu garanto que os resultados do estudo serão devolvidos aos participantes por meio de uma apresentação oral em local e horário a ser combinado, podendo ser publicados posteriormente na comunidade científica, sempre garantindo o anonimato dos participantes.

Este projeto foi revisado e aprovado pelo Comitê de Ética em Pesquisa do Instituto de Ciências Humanas da Universidade de Brasília - CEP/IH. As informações com relação à assinatura do TCLE ou os direitos do sujeito da pesquisa podem ser obtidos através do e-mail do CEP/IH cep_ih@unb.br.

Este documento foi elaborado em duas vias, uma ficará com o(a) pesquisador(a) responsável pela pesquisa e a outra com o senhor(a).

Brasília, de de 


\section{ANEXO III}

\section{Termo de Autorização para Utilização de Imagem e Som de Voz para fins de pesquisa} $\mathrm{Eu}$, autorizo a utilização da minha imagem e som de voz, na qualidade de participante/entrevistado(a) no projeto de pesquisa intitulado "Transições de desenvolvimento da adolescência à juventude no campo da experiência vocacional religiosa: contribuições à psicologia dialógica”, sob responsabilidade de Cláudio Márcio de Araújo, vinculado(a) ao/à Departamento de Psicologia Escolar e do Desenvolvimento, Instituto de Psicologia da Universidade de Brasília (PED/IP/UnB).

Minha imagem e som de voz podem ser utilizadas apenas para análises por parte do responsável por esta pesquisa.

Tenho ciência de que não haverá divulgação da minha imagem nem som de voz por qualquer meio de comunicação, sejam elas televisão, rádio ou internet, exceto nas atividades vinculadas ao ensino e a pesquisa explicitadas acima. Tenho ciência também de que a guarda e demais procedimentos de segurança com relação às imagens e sons de voz são de responsabilidade do(a) pesquisador(a) responsável.

Deste modo, declaro que autorizo, livre e espontaneamente, o uso para fins de pesquisa, nos termos acima descritos, da minha imagem e som de voz.

Este documento foi elaborado em duas vias, uma ficará com o(a) pesquisador(a) responsável pela pesquisa e a outra com o(a) participante. de de 


\section{ANEXO IV}

\section{GUIA DE EVOCAÇÃO DE NARRATIVAS ESCRITAS}

\section{IDENTIFICAÇÃO:}

No

Sexo: Idade:

Escolaridade:

Telefones:

Email:

Eu, Cláudio Márcio de Araújo, estou realizando uma pesquisa sobre transições de desenvolvimento junenil e gostaria de contar com sua participação para escrever um pouco, na forma de uma história, sobre as experiências que você considera importantes no seu processo de reconhecimento de si como vocacionado(a) à vida religiosa.

Como sugestão você pode falar sobre:

(1) como começou a pensar sobre a possibilidade de ser um(a) religioso(a);

(2) pessoas que foram/são importantes nesta escolha;

(3) mudanças significativas que esta escolha trouxe;

(4) momentos de certeza e incerteza sobre esta escolha;

(5) suas perspectivas futuras em relação à sua vocação; 


\section{ANEXO V \\ ROTEIRO DE ENTREVISTA DO TIPO HISTÓRIA DE VIDA \\ (utilizado com os quatro jovens)}

\section{IDENTIFICAÇÃO}

Agradecimentos!

ASPECTOS ÉTICOS DA PESQUISA (esclarecimentos): anonimato, liberdade para responder ou não às questões, bem como interromper a entrevista se desejar.

\section{INFÂNCIA}

Descrever: ambiente em que foi criado; profissão dos pais; relacionamento entre os membros familiares; valores; outros adultos importantes nesta época; lembranças significativas; Sugestões de perguntas:

$\checkmark$ Você pode me falar um pouco sobre seu ambiente familiar quando você era criança?

$\checkmark$ Como foi sua infância e a dos seus irmãos?

$\checkmark$ Quando criança, como era a organização da sua família em relação a trabalhos e estudos?

$\checkmark$ Seus pais/responsáveis comentam fatos interessantes desta época?

$\checkmark$ Você tem alguma história que recorda com emoção de quando era criança?

$\checkmark$ Como você se relacionava com seus familiares?

$\checkmark$ Havia outros adultos importantes para você na infância?

$\checkmark$ Quais eram os valores que predominavam no ambiente em que você foi criado/a?

\section{ADOLESCÊNCIA}

Descrever: ambiente familiar; outras esferas de experiência; interações com os membros familiares; valores; outros adultos importantes nesta época; lembranças significativas; sexualidade em relação às mudanças no corpo, namoro; lazer; amizades; mudanças significativas;

Sugestões de perguntas:

$\checkmark$ Fale-me um pouco sobre quando se viu como um/a adolescente?

$\checkmark$ Ocorreram mudanças na sua forma de pensar quando começou a vivenciar a adolescência?

$\checkmark$ Você ainda se sente adolescente?

$\checkmark$ Como você percebia o seu contexto familiar enquanto adolescente?

$\checkmark$ Que objetos julga importantes na sua adolescência?

$\checkmark$ Fale um pouco sobre as pessoas que foram significativas na sua adolescência?

$\checkmark$ As mudanças biológicas, internas e externas ao seu corpo representaram transformações importantes para você na adolescência? 
$\checkmark$ O que fazia/faz você se sentir bem, realizado/a na adolescência?

$\checkmark$ Quais são as lembranças mais significativas deste momento da sua vida?

$\checkmark$ Fale um pouco sobre seu relacionamento com seus familiares?

$\checkmark$ Como adolescente, quais eram/são seus principais valores?

$\checkmark$ De um modo geral, como você percebe a sua adolescência?

$\checkmark$ De modo geral, como você percebe(u) a adolescência de seus irmãos/as?

$\checkmark$ Você tem alguma história na sua adolescência que recorda com emoção?

$\checkmark$ Como as pessoas percebiam você enquanto adolescente?

$\checkmark$ Como eram/são suas amizades na adolescência?

$\checkmark$ Quais as formas de lazer mais presentes na sua adolescência?

\section{VIDA ESCOLAR NA ADOLESCÊNCIA}

Descrever: padrões de relacionamento na vida escolar; comportamento e desempenho escolar; colegas de escola; mudanças significativas;

Sugestões de perguntas:

$\checkmark$ Como era/é sua relação com os estudos na adolescência?

$\checkmark$ Você gostava de fazer amizades na escola?

$\checkmark$ O que caracteriza um adolescente?

$\checkmark$ Como você se percebia/percebe enquanto estudante adolescente?

$\checkmark$ Você tem lembranças marcantes desse momento?

\section{VIDA RELIGIOSA}

Descrever: amizades; aproximação da instituição religiosa; organização para a ingressar no seminário/convento; mudanças significativas; adaptação; dificuldades; momentos de dúvida; perspectivas futuras;

Sugestões de perguntas:

$\checkmark$ Quando você se percebeu vocacionado/vocacionada? Como foi este momento?

$\checkmark$ Você passou por momentos de dúvida da sua vocação?

$\checkmark$ O que ou quem para você foi fundamental nestes momentos de dúvida?

$\checkmark$ Existe um ou mais motivos que te levou/levaram a escolher a vida religiosa?

$\checkmark$ Na escola muitas pessoas sabiam da sua vocação a vida religiosa?

$\checkmark$ Você se sentia diferente dos seus colegas por ser um/uma vocacionado/vocacionada?

$\checkmark$ Como você conciliava seus estudos com a experiência de ser um/uma vocacionado/vocacionada?

$\checkmark$ Ocorreram mudanças a partir do momento que você decidiu se assumir como vocacionado/vocacionada a vida religiosa? 
$\checkmark$ Ocorreram mudanças no seu modo de ser, de se comportar, depois de se assumir como vocacionado/vocacionada a vida religiosa?

$\checkmark$ Ocorreram mudanças no seu modo de pensar a vida religiosa?

$\checkmark$ Ocorreram transformações na forma de você se relacionar com seus familiares depois de se assumir como vocacionado/vocacionada a vida religiosa?

$\checkmark$ Seus parentes e amigos mudaram a forma de verem você após saberem que você era um/uma vocacionado/vocacionada a vida religiosa?

$\checkmark$ Você mudou a forma de se ver após ter se assumido como vocacionado/vocacionada a vida religiosa?

$\checkmark$ Como você se vê no futuro?

$\checkmark$ Quais são seus medos e expectativas em relação ao futuro?

ENTRADA NO CONVENTO/SEMINÁRIO (participantes que já moram em uma casa de formação)

Descrever: mudanças significativas; adaptação; dificuldades; momentos de dúvida; autoimagem; perspectivas futuras;

Sugestões de perguntas:

$\checkmark$ O que significou para você a saída do ambiente familiar?

$\checkmark$ Como foi a sua adaptação ao ambiente do convento/seminário?

$\checkmark$ Você passou por momentos de dúvida em relação à sua vocação depois de estar no convento/seminário?

$\checkmark$ O que ou quem para você foi fundamental nestes momentos de dúvida?

$\checkmark$ Ocorreram mudanças no seu modo de ser, de se comportar, depois que entrou na vida religiosa?

$\checkmark$ Ocorreram mudanças no seu modo de pensar a vida religiosa depois que entrou no convento/seminário?

$\checkmark$ Ocorreram transformações na forma de você se relacionar com seus familiares depois de entrar na vida religiosa?

$\checkmark$ Seus parentes e amigos mudaram a forma de verem você após sua entrada no seminário/convento?

$\checkmark$ Você mudou a forma de se ver após ter entrado no seminário/convento?

$\checkmark$ Você se sente adolescente?

$\checkmark$ (se ele/ela se sentir adolescente) Você se sente um/a adolescente diferente de quando estava fora do convento/seminário? Alguma coisa mudou?

$\checkmark$ (se ele/ela não se sentir adolescente) Quando você começou a sentir que não era mais um/uma adolescente? O que mudou? 
$\checkmark$ Você se sente uma religioso/religiosa hoje?

$\checkmark \quad$ O que pode fazer uma pessoa se sentir religioso/a?

$\checkmark$ Quais suas expectativas futuras em relação à sua vocação?

$\checkmark$ Como você se vê nos próximos 12 meses; 


\section{ANEXO VI}

\section{ROTEIRO DE ENTREVISTA DO TIPO EPISÓDICA}

(utilizado com a jovem Cecília)

Reafirmação do anonimato;

TEMAS A SEREM ABORDADOS

$\checkmark$ Relações interpessoais no grupo de jovens e na Pastoral de Rua;

$\checkmark$ Tensões vivenciadas na família após a decisão de ingressar no convento;

$\checkmark$ Preparação para ingressar no convento;

$\checkmark$ Adaptações à rotina do convento;

$\checkmark$ Sentimentos e emoções relacionadas ao rito de vestição;

$\checkmark$ Expectativas relacionadas à escolha do nome religioso;

$\checkmark$ A experiência do nome religioso;

$\checkmark$ Expectativas e vivências do noviciado;

$\checkmark$ Dúvidas e receios;

$\checkmark$ Relacionamento com o pai e o irmão;

$\checkmark$ Expectativas relacionadas à profissão temporária;

$\checkmark$ Projetos futuros;

$\checkmark$ Desenho mental da própria trajetória de vida em quatro quadrinhos;

Agradecimentos

Confirmação de um último encontro para devolutiva da pesquisa antes da defesa do trabalho. 


\section{ANEXO VII}

\section{ROTEIRO DE ENTREVISTA DO TIPO EPISÓDICA}

(utilizado com a jovem Fátima)

Reafirmação do anonimato;

TEMAS A SEREM ABORDADOS

$\checkmark$ Relações interpessoais na família;

$\checkmark$ A experiência como coroinha;

$\checkmark$ O reconhecer-se vocacionada à vida religiosa consagrada;

$\checkmark$ Tensões vivenciadas após a decisão de ingressar no convento;

$\checkmark$ Adaptação à rotina do convento;

$\checkmark$ Tensões vivenciadas no primeiro ano de noviciado;

$\checkmark$ Dúvidas e receios vivenciados no primeiro ano de noviciado;

$\checkmark$ A transição do primeiro para o segundo ano de noviciado;

$\checkmark$ A experiência no segundo ano de noviciado;

$\checkmark$ Expectativas relacionadas à profissão temporária;

$\checkmark$ A decisão e experiência de usar hábito em uma congregação que não tem essa tradição;

$\checkmark$ O sentido do hábito;

$\checkmark$ O sentido dos votos de pobreza, castidade e obediência;

$\checkmark$ Expectativas e receios em relação ao futuro;

$\checkmark$ Projetos futuros;

$\checkmark$ Desenho mental da própria trajetória de vida em quatro quadrinhos;

Agradecimentos

Confirmação de um último encontro para devolutiva da pesquisa antes da defesa do trabalho. 


\section{ANEXO VIII}

\section{ROETIRO DE ENTREVISTA DO TIPO EPISÓDICA}

(utilizado com o jovem Francisco)

Reafirmação do anonimato

\section{TEMAS A SEREM ABORDADOS}

$\checkmark$ Relacionamentos interpessoais na família;

$\checkmark$ O episódio ocorrido no aniversário de 16 anos, em 2006;

$\checkmark$ O episódio vivenciado no retiro, com o bispo;

$\checkmark$ Medos e receios vividos no postulantado;

$\checkmark$ Medos e receios vividos no noviciado;

$\checkmark$ Finalização do noviciado;

$\checkmark$ Preparativos para a profissão temporária;

$\checkmark$ A profissão temporária;

$\checkmark$ A experiência de professar os votos religiosos;

$\checkmark$ O ingressar no curso de Filosofia;

$\checkmark$ A experiência como universitário religioso consagrado;

$\checkmark$ Expectativas em relação ao futuro;

$\checkmark$ Medos e receios em relação ao futuro;

$\checkmark$ Representação mental da própria trajetória de vida em quatro quadrinhos;

Agradecimentos

Confirmação de um último encontro para devolutiva da pesquisa antes da defesa do trabalho. 


\section{ANEXO IX}

\section{ROTEIRO DE ENTREVISTA DO TIPO EPISÓDICA}

(utilizado com o jovem Vicente)

Reafirmação do anonimato;

\section{TEMAS A SEREM ABORDADOS}

$\checkmark$ Relações interpessoais com os familiares;

$\checkmark \quad$ A escolha entre ser militar ou ser padre;

$\checkmark$ A experiência como universitário;

$\checkmark$ O papel da filosofia na sua trajetória vocacional;

$\checkmark$ Dúvidas e receios vivenciados antes de ingressar no noviciado;

$\checkmark$ O ingressar no noviciado;

$\checkmark$ A experiência de morar em cidades diferentes a cada etapa de formação;

$\checkmark$ O desejo de ser missionário;

$\checkmark$ A escolha entre ser clérigo ou leigo consagrado;

$\checkmark$ Dúvidas e receios vivenciados no noviciado;

$\checkmark$ Preparação e vivência do rito celebrativo da profissão temporária;

$\checkmark$ A experiência dos votos religiosos;

$\checkmark$ Expectativas futuras;

$\checkmark$ A pastoral dos surdos;

$\checkmark$ A escolha por cursar Teologia;

$\checkmark$ Desenho mental da própria trajetória de vida em quatro quadrinhos;

Agradecimentos

Confirmação de um último encontro para devolutiva da pesquisa antes da defesa do trabalho. 